UNIVERSIDADE DE SÃO PAULO

\author{
ESCOLA DE ENGENHARIA DE SÃO CARLOS
}

PROGRAMA DE PÓS-GRADUAÇÃO EM REDE NACIONAL PARA ENSINO DAS

CIÊNCIAS AMBIENTAIS - PROFCIAMB

YARA SANTUCCI BARRETO

O espaço escolar sustentável como educador. 
YARA SANTUCCI BARRETO

\section{O espaço escolar sustentável como educador.}

\section{Versão original}

Dissertação apresentada à Escola de Engenharia de São Carlos, da Universidade de São Paulo, para a obtenção do título de Mestre em Ciências Ambientais, Programa de Pós-Graduação em

Rede Nacional para Ensino das Ciências Ambientais - PROFCIAMB.

Área de concentração: Ensino das Ciências Ambientais. Linha de atuação: Ambiente e Sociedade

Orientadora:

Prof. ${ }^{\text {a }}$ Dr ${ }^{\text {a }}$ Fernanda da Rocha Brando Fernandez 
AUTORIZO A REPRODUÇÃO TOTAL OU PARCIAL DESTE TRABALHO,

POR QUALQUER MEIO CONVENCIONAL OU ELETRÔNICO, PARA FINS DE ESTUDO E PESQUISA, DESDE QUE CITADA A FONTE.

Ficha catalográfica elaborada pela Biblioteca Prof. Dr. Sérgio Rodrigues Fontes da EESC/USP com os dados inseridos pelo(a) autor(a).

Barreto, Yara Santucci

o espaco escolar sustentável como educador. I Yara Santucci Barreto; orientadora Fernanda da Rocha Brando Fernandez. Sáo Carlos, 2021.

Dissertação (Mestrado) - Programa de Mestrado Profissional em Rede Nacional para Ensino das Ciências Ambientais e Área de Concentração em Ensino das Ciencias Ambientais -- Escola de Engenharia de São Carlos da Universidade de São Paulo, 2021.

1. Escola Sustentável. 2. Espaço escolar. 3. Adequação ambiental. 4. Ciências ambientais. 5. Projeto político-pedagógico. I. Título.

Eduardo Graziosi Silva - CRB - 8/8907 


\section{FOLHA DE JULGAMENTO}

Candidata: Arquiteta e Urbanista YARA SANTUCCI BARRETO.

Título da dissertação: " O espaço escolar sustentável como educador ".

Data da defesa: 18/10/2021.

Comissão Julgadora

$\underline{\text { Resultado }}$

Profa. Associada Fernanda da Rocha Brando Fernandez (Orientadora)

(Faculdade de Filosofia, Ciências e Letras de Ribeirão Preto/FFCLRP-USP)

Profa. Dra. Doris Catharine Cornelie Knatz Kowaltowsk

APROVADA

(Universidade Estadual de Campinas/UNICAMP)

Prof. Dr. Rodolfo Antônio de Figueiredo

APROVADA

(Universidade Federal de São Carlos/UFSCar)

Coordenador do Programa de Pós-Graduação em Rede Nacional para Ensino das Ciências Ambientais:

Prof. Associado Juliano José Corbi

Presidente da Comissão de Pós-Graduação:

Prof. Titular Murilo Araujo Romero 
Dedico este trabalho ao Ulysses, meu filho, que além de me inspirar a ser uma pessoa cada vez melhor, despertou mais intensamente em mim o objetivo de permanecer perto das crianças e jovens e à eles passar a dedicar o meu trabalho. 


\section{AGRADECIMENTOS}

Sou grata à Natureza, que continuamente me inspira. Aos meus pais, por me ensinarem a amá-la. Sou grata sobretudo ao amor, suporte e parceria do meu núcleo familiar e ao lar que compomos.

Um especial agradecimento à minha orientadora Prof. ${ }^{\mathrm{a}}$ Dr ${ }^{\mathrm{a}}$ Fernanda da Rocha Brando Fernandez pelo incentivo, suporte e confiança a mim devotada. 


\section{BIOGRAFIA}

Atuar intensamente por 20 anos como arquiteta e paisagista em São Paulo dentro do modelo convencional de projetos e execuções residenciais, comerciais e institucionais me fez presenciar toda sorte de experiências e também inconsciências - de descartes insanos à consumos ostentatórios. Interrompi e alterei minhas escolhas.

Em novas formações holísticas e imersão em diversas novas práticas e reflexões, venho redescobrindo desde 2011 a arquitetura sob a forma sustentável e bioecológica e me redescobrindo como profissional. Embora ainda rejeitado por muitos, esse é um caminho inexorável a todas as profissões ou indivíduos. E cidades também. O caminho do bom-senso, da consciência global, da visão sistêmica.

Essa reciclagem profissional trouxe atuações igualmente renovadoras. Dentre projetos de arquitetura sustentável para reforma e construção na capital e interior, destaca-se a experiência em que passei a atuar por 18 meses como gerente de uso e conservação sustentável em escola particular de ensino básico com 800 alunos em São Paulo, que conjugou ações de arquitetura, análises de conforto, sustentabilidade aplicada e manutenção predial. Assumi a gestão dessas ações e dos atores envolvidos. Desenvolvi na ocasião um instrumento digital interativo para dar autonomia à administração escolar para seguir em ações planejadas segundo necessidades específicas encontradas - um Plano Diretor para uma gestão responsável e sustentável, elaborado para aquele estabelecimento escolar, porém replicável noutras instâncias escolares ou até mesmo noutras áreas, como já ocorreu em empresas, residências e centro de turismo e lazer.

É sempre uma grande satisfação poder polinizar por meio do meu trabalho a consciência ecológica e proporcionar uma visão sistêmica ao menos sobre o próprio meio ambiente diário de cada unidade atendida.

Venho defendendo valores perenes e respeito raízes culturais locais. Busco imprimir sempre que possível um cunho educativo aos projetos e ações que executo como forma de fortalecer e polinizar conceitos, discussões, reflexões, práticas sustentáveis e ecológicas, o que acredito ser indispensável ao progresso real da sociedade. 
BARRETO, Y. S. O espaço escolar sustentável como educador. 2021. Dissertação (Mestrado em Ensino das Ciências Ambientais) - Programa de Pós-graduação em Rede Nacional para Ensino das Ciências Ambientais, Escola de Engenharia de São Carlos, Departamento de Hidráulica, da Universidade de São Paulo, São Paulo, 2021.

\section{RESUMO}

\section{O espaço escolar sustentável como educador.}

Esta pesquisa visa favorecer a transição de espaços escolares construídos para o conceito Escola Sustentável por meio de um guia de princípios da sustentabilidade na instância escolar, com fins de nela detectar as demandas de adequação a serem atendidas para tal alinhamento. $\mathrm{O}$ exercício de percepção e análise de seu próprio território e realidade poderá conduzir a comunidade escolar ao seu autoconhecimento, à apropriação do meio ambiente em que se insere de forma consciente, responsável e interdisciplinar e ainda estimular sua visão sistêmica e transversalidade pedagógica. A inclusão do espaço escolar sustentável no projeto político-pedagógico possibilitaria ensinar as vertentes das ciências ambientais de forma aplicada, favorecendo práticas, diálogos e contextualizações educativas diversas e estimulando o hábito salutar de tais procedimentos dentro do espaço escolar. Apresenta-se preliminarmente relato de experiência pregressa de uma gestão de intervenções de adequação ambiental de espaços físicos aos preceitos da sustentabilidade, realizada em uma escola particular de ensino básico da cidade de São Paulo (SP) ao longo de 18 meses, que fomentou o processo de elaboração do produto deste mestrado profissional. A metodologia da análise documental e bibliográfica com análise de conteúdo foi adotada para investigar o conceito Escola Sustentável para incorporá-lo ao instrumento produzido. Este trabalho busca possibilitar ao espaço escolar - uma vez alinhado ao conceito Escola Sustentável e assistido pela sua comunidade - realizar valores e conteúdos didáticos teorizados em sala de aula, proporcionar um maior repertório de experiências interativas, bem como de contextualizações pedagógicas, além de restabelecer o necessário conforto e bem-estar aos seus usuários.

Palavras-chave: Escola Sustentável. Espaço escolar. Adequação ambiental. Ciências ambientais. Projeto político-pedagógico. 
BARRETO, Y. S. Sustainable school space as an education agent. 2021. Dissertação (Mestrado em Ensino das Ciências Ambientais) - Programa de Pós-graduação em Rede Nacional para Ensino das Ciências Ambientais, Escola de Engenharia de São Carlos, Departamento de Hidráulica, da Universidade de São Paulo, São Paulo, 2021.

\section{ABSTRACT \\ Sustainable school space as an education agent.}

This research aims to promote the transition of school built spaces to the Sustainable School Concept through a guide to sustainability principles for school environment, in order to detecting the adequacy demands to be met for such alignment. The analysis and experiencial perception of its own territory and reality can bring self-awarenes to school Community, a conscious, responsible and interdisciplinary appropriation of school environment, and also encouragement to apply systemic vision and pedagogical transversality approaches. The insertion of a sustainable school space concept in school political-pedagogical project would make it possible to teach practical aspects of environmental sciences, fostering different educational activities, dialogues, contextualizations and promoting the healthy habit of such procedures within the school environment. This research presents a preliminary report of a past experience on managing interventions for the adaptation of the existing physical spaces environmental to the principles of sustainability, carried out in a private elementary school in the city of São Paulo (SP) over 18 months, which served as a base for the elaboration of production process of this professional master's degree. The methodology of documental and bibliographic analysis with content examination was adopted to investigate the Sustainable School Concept to integrate it into the instrument produced. This work seeks to enable the school environment - once aligned with the Sustainable School Concept and assisted by its community - to fulfill values and accomplish classroom theory didactic contents, providing a greater repertoire of interactive experiences, as well as pedagogical contextualizations, in addition to restoring the necessary comfort and well-being of school community.

Keywords: Sustainable School. School physical space. Environmental suitability. Environmental Sciences. Political-pedagogical project. 


\section{LISTA DE FIGURAS}

Figura 1 A equanimidade sustentável entre os 3 sistemas principais e suas intersecções

Figura 2 Metodologia de trabalho

Figura 3 Linha do tempo dos trabalhos desenvolvidos

p. 52

Figura 4 Unidades de registro distribuídas em categorias

p. 60

Figura 5 Categorias das literaturas

p. 65

Figura 6 Diversidade entre programas de educação para a sustentabilidade em escolas

p. 72

Figura 7 Certificações ambientais de edificações

p. 73

Figura 8 Gráfico das Escolas Sustentáveis - PNES

p. 76

Figura 9 Categorias segundo as incidências totais e resultantes das unidades de registro

Figura 10 Diagrama de sistemas complexos

p. 101

Figura 11 Modelo equânime de composição de grupo multidisciplinar em instância escolar

\section{LISTA DE FOTOS}

Foto 1 Situação original do espaço sobre laje de cobertura das salas de aula

Foto 2 Ações de adequação, Fase I: permeabilização do pátio, reforma dos banheiros e muro verde

Foto 3 Apropriações e contextualizações pedagógicas registradas após conclusão da Fase I das adequações sustentáveis

p. 30

Foto 4 Referências culturais encontradas no espaço da instância escolar

p. 34

Foto 5 Exemplos de ações de adequação, Fase II

Foto 6

Ações de adequação, Fase III: requalificação de pátio ocioso,

Foto 7 Situação existente de bebedouros e salas de aula

\section{LISTA DE IMAGENS}

Imagem 1 Anteprojeto da Praça Sustentável

p. 23

Imagem 2

Projetos futuros: bebedouros, salas de aula Infantil, Fundamental I, II e Ensino Médio 


\section{LISTA DE TABELAS}

$\begin{array}{lll}\text { Tabela } 1 \quad \text { Questões de pesquisa } & \text { p. } 19\end{array}$

$\begin{array}{lll}\text { Tabela } 2 \text { Categorias das demandas - RMUCS } & \text { p. } 35\end{array}$

$\begin{array}{lll}\text { Tabela } 3 & \text { Demandas encontradas e atendidas até outubro de } 2014 & \text { p. } 37\end{array}$

Tabela 4 Ações de Adequação - Fase I p. 39

$\begin{array}{lll}\text { Tabela } 5 \text { Ações de Adequação - Fase II } & \text { p. } 39\end{array}$

$\begin{array}{lll}\text { Tabela } 6 & \text { Ações de Adequação - Fase III p. } 43\end{array}$

$\begin{array}{lll}\text { Tabela } 7 & \text { Estudos e Projetos para Ações Posteriores } & \text { p. } 48\end{array}$

$\begin{array}{lll}\text { Tabela } 8 & \text { Análise da legenda de caracteres } & \text { p. } 53\end{array}$

$\begin{array}{lll}\text { Tabela } 9 & \text { Unidades de análise para busca } & \text { p. } 58\end{array}$

$\begin{array}{ll}\text { Tabela } 10 \text { Modelo de ficha } & \text { p. } 59\end{array}$

$\begin{array}{ll}\text { Tabela } 11 \text { Modelo de ficha - textos primários } & \text { p. } 59\end{array}$

Tabela 12 Linha histórica institucional da Educação Ambiental e

Sustentabilidade no Brasil a partir de movimentos internacionais p. 77

$\begin{array}{lll}\text { Tabela } 13 \text { Categorias de análise } & \text { p.93 }\end{array}$

$\begin{array}{lll}\text { Tabela } 14 & \text { Princípios do conceito Escola Sustentável p. } 105\end{array}$ 


\section{LISTA DE ABREVIATURAS E SIGLAS}

CEA Centro de Educação Ambiental

CEA Centros de Educação Ambiental

CNE Conselho Nacional de Educação do Ministério de Educação

CNIJMA Conferência Nacional Infantojuvenil pelo Meio Ambiente

COM-Vida Comissão de Meio Ambiente e Qualidade de Vida na Escola

EA Educação Ambiental

EDS Educação para o Desenvolvimento Sustentável

MEC Ministério da Educação e Cultura

MMA Ministério do Meio Ambiente

ODS Objetivos de Desenvolvimento Sustentável

PDDE Programa Dinheiro Direto na Escola

PNEA Política Nacional de Educação Ambiental

PNES Programa Nacional Escolas Sustentáveis

PNMA Politica Nacional de Meio Ambiente

PNUMA Programa de Meio Ambiente da ONU

PPP Projeto Político-pedagógico

ProNEA Programa Nacional de Educação Ambiental

RMUCS Relatório e Mapeamento de Uso e Conservação Sustentável

SECADI Secretaria de Educação Continuada, Alfabetização e Diversidade

SEMA Secretaria Especial do Meio Ambiente 


\section{SUMÁRIO}

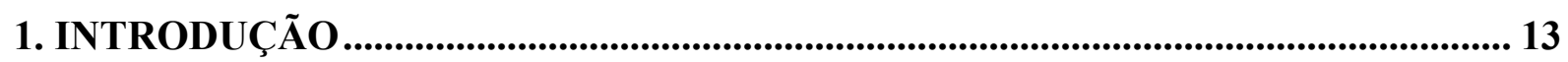

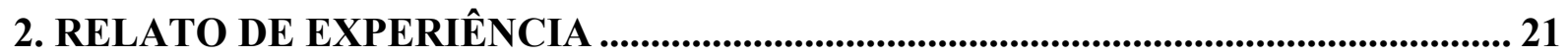

2.1. UMA PRAÇA SUSTENTÁVEL ELEVADA - JUNHO A NOVEMBRO DE 2012...... 22

2.2. RELATÓRIO E MAPEAMENTO DE USO E CONSERVAÇÃO SUSTENTÁVEL (RMUCS) - MAIO DE 2013 …………………………………………………..... 24

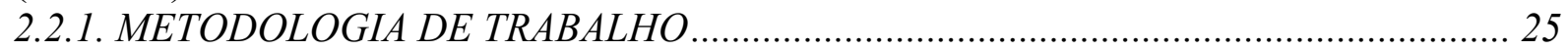

2.3. AÇÕES DE ADEQUAÇÃO - FASE I - JUNHO A JULHO DE 2013 ............................ 28

2.4. RELATÓRIO E MAPEAMENTO DE USO E CONSERVAÇÃO SUSTENTÁVEL (RMUCS) - AGOSTO A OUTUBRO DE 2013 ............................................................. 31

2.5. AÇÕES DE ADEQUAÇÃO - FASE II - NOVEMBRO DE 2013 A FEVEREIRO DE 2014. 38

2.6. AÇÕES DE ADEQUAÇÃO - FASE III - MARÇO A OUTUBRO DE 2014 ………..... 42

2.7. ESTUDOS E PROJETOS PARA AÇÕES POSTERIORES - MARÇO A OUTUBRO DE 2014.

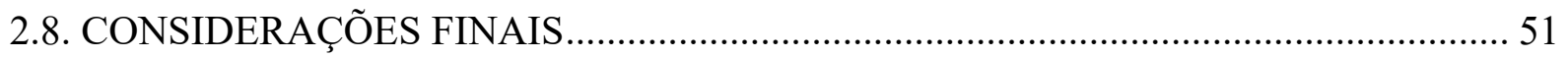

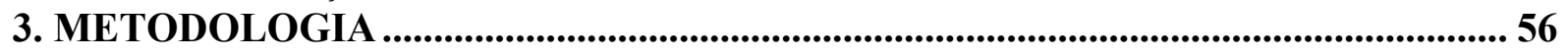

3.1. ANÁLISE DOCUMENTAL E BIBLIOGRÁFICA ……………………………........... 56

4. REVISÃO DE LITERATURA ............................................................................................. 61

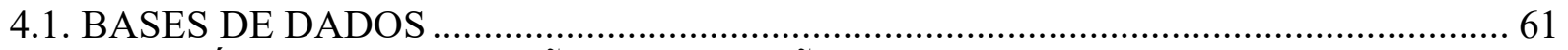

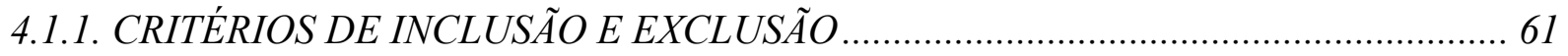

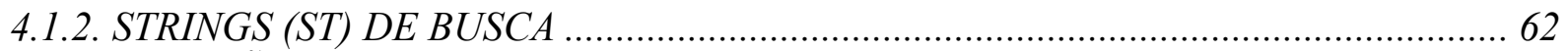

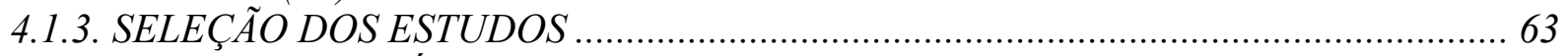

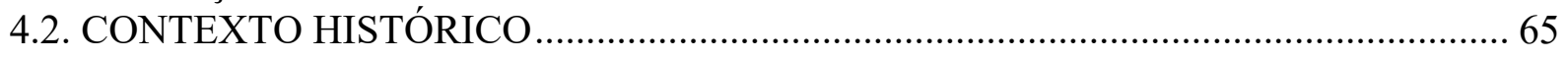

4.2.1. DESASTRES AMBIENTAIS ............................................................................. 66

4.2.2. LINHA HISTÓRICA INSTITUCIONAL DA EDUCAÇÃO AMBIENTAL E

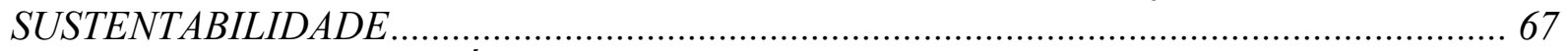

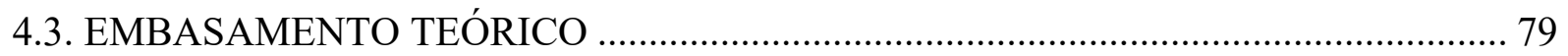

5. RESULTADOS E DISCUSSÃO ................................................................................ 85

5.1. TEXTOS PRIMÁRIOS E SECUNDÁRIOS ..................................................................... 85

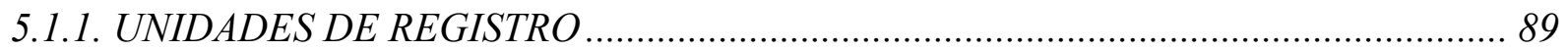

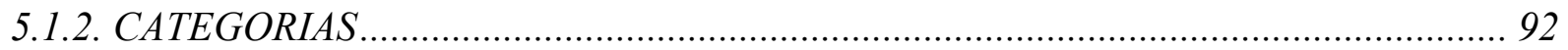

5.2. O CONCEITO ESCOLA SUSTENTÁVEL …………............................................ 102

5.3. GUIA DE PRINCÍPIOS DA ESCOLA SUSTENTÁVEL …………………….......... 120

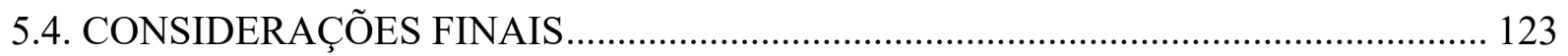

6. CONCLUSÕES ……………………………………………………………………………… 128

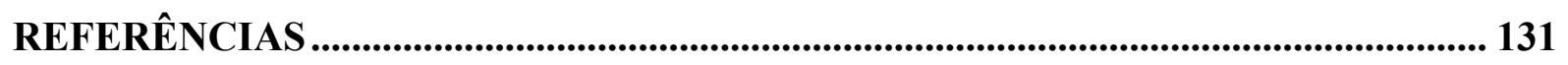

PRODUTO FINAL: GUIA DE PRINCÍPIOS DA ESCOLA SUSTENTÁVEL.............. 139 


\section{INTRODUÇÃO}

\section{Contextualização}

Programas educacionais ao redor do mundo buscam desde a década de 90, especialmente após a Cúpula da Terra da ONU em 1992, incluir o aprendizado da sustentabilidade na prática diária dentro da escola e torná-las modelos da Educação para o Desenvolvimento Sustentável (EDS), termo adotado a partir de então. Estima-se um número crescente além de 100 mil escolas filiadas a esses programas, que neste momento pelos diversos métodos que oferecem já se encontram adequadas ou em processo de adequação ao contexto atual de demandas globais, apresentadas desde há décadas à sociedade por relatórios e agendas mundiais. (GOUGH; GOUGH, 2019). Suportes governamentais e institucionais continuados vêm sendo essenciais no fortalecimento e multiplicação desses programas.

No Brasil, o Programa Nacional Escolas Sustentáveis (PNES) nasceu somente em 2013 e não sobreviveu além de 2016, sendo descontinuado após a crise econômica de 2015 no país. Desde 2007, porém, a Comissão de Meio Ambiente e Qualidade de Vida na Escola (COMVida), assistida pelo órgão gestor da Política Nacional de Educação Ambiental (PNEA) formado pelo MEC e MMA, que chegou a ser incorporada ao plano de ação pretendido pelo PNES, chegou a levar a Agenda 21 para dentro de 16.538 escolas $^{1}$, e, mesmo tendo sido concebida como uma ação estruturante do Programa Vamos Cuidar do Brasil com as Escolas, também descontinuado, permanece em algumas instâncias escolares. (SILVA; SANTANA, 2018; BOGADO; FREITAS, 2017; BRASIL, 2007a; 2013c; 2017).

Outro programa brasileiro, o Programa Dinheiro Direto na Escola (PDDE), voltado a financiar ações de melhoria da qualidade de ensino, embora atuante há 26 anos, a sua modalidade PDDE-Escolas Sustentáveis, criada para financiar ações de melhoria nas escolas especificamente sob "critérios de sustentabilidade socioambiental, considerando o currículo, a gestão e o espaço físico, de forma a tornarem-se espaços educadores sustentáveis” (p. 3), vigorou apenas enquanto o PNES durou. (BRASIL, 2013a; 2014a; 2014c).

"Existem dois aspectos no aprendizado da sustentabilidade - aprender sobre o problema e se engajar com o problema", ponto de vista defendido por um dos programas mais difundidos, o Eco-Schools, que em 25 anos já realizou mudanças em 59mil escolas em 68

1 Número atingido na IV CNIJMA (2013), edição de maior repercussão que a Conferência Nacional Infantojuvenil pelo Meio Ambiente já teve, curiosamente com o tema "Espaço físico escolar" inserido na sua temática, junto com "Gestão democrática" e "Currículo escolar". (BRASIL, 2013c). 
países. O envolvimento direto da comunidade escolar na resolução de problemas, que se refletem em seu microcosmo a partir do cenário global, permite que desenvolva "habilidades, atitudes e valores necessários para moldar um futuro sustentável" e a encoraja a proporcionar, especialmente às novas gerações representadas pelos alunos, "competências de um cidadão ativo", ao invés de meramente apresentar-lhes os problemas passivamente, ou de transferi-los a instituições governamentais ou corporações. (SHARMA, 2018).

Independente do potencial educador do espaço físico per se, surge a reflexão de que as escolas necessitam ser ou se tornar alinhadas ao conceito do desenvolvimento sustentável, o qual pressupõe aspectos como: bem comum, integração, multi e interdisciplinaridade, ética social e ambiental (LÉLÉ, 1991; KATES; PARRIS; LEISEROWITZ, 2005) e ser exemplar à sua comunidade, pela simples razão de ser considerado um educador, como Kowaltowski e Strong-Wilson pontuam:

Na Alemanha, com o final da Segunda Guerra Mundial, houve a necessidade da reconstrução, inclusive das edificações escolares. Por seu papel pedagógico, o prédio escolar recebeu mais atenção, quando o espaço passou a ser visto como um terceiro professor (o $1^{\circ}$ é o profissional; o $2^{\circ}$ é o material didático, e o $3^{\circ}$ é o ambiente escolar). Almeja-se ampliar a experiência dos alunos por meio de projetos diferenciados e com aparências que intriguem, questionem e envolvam a população. (SYVERTSEN, 2010², apud KOWALTOWSKI, 2011, p.71).

A abordagem de Reggio Emilia ${ }^{3}$ à educação fala sobre três educadores que estão na sala de aula ao mesmo tempo: o professor, a criança e o meio ambiente. [...] Ao ver o meio ambiente como um educador, como faz a abordagem de Reggio Emilia, podemos começar a perceber como nosso entorno pode ter uma vida própria que contribui para o aprendizado das crianças. A infância é muitas vezes quando começamos a ver e usar o meio ambiente com imaginação. (STRONG-WILSON, 2007 , p. 40, tradução nossa).

O espaço físico escolar necessita corroborar e fortalecer o argumento da sustentabilidade, assumindo e incorporando práticas para desenvolver uma cultura de sustentabilidade no ambiente escolar. (DAVIS; COOKE, 2007, tradução nossa).

A exemplo da COM-Vida, que traz indicadores importantes sobre o envolvimento de comunidades escolares brasileiras nesse alinhamento por meio da aplicação prática da Agenda 21 nas escolas, leem-se os atuais dezessete Objetivos de Desenvolvimento Sustentável (ODS) da Agenda 2030, que declara em sua introdução:

Esta é uma Agenda de alcance e significado sem precedentes. Ela é aceita por todos os países e é aplicável a todos, levando em conta diferentes realidades nacionais, capacidades e níveis de desenvolvimento e respeitando as políticas e prioridades nacionais. Estes são objetivos e metas universais que envolvem todo o mundo,

2 SYVERTSEN, John; PIGOZZI, Architects O.'Donnell Wicklund. The third teacher: 79 ways you can use design to transform teaching \& learning. Abrams, 2010.

3 A história do programa pedagógico de Reggio Emilia, desde sua origem, é contada por seu fundador, Loris Malaguzzi, em entrevista à Lella Gandini no capítulo 3 do livro The Hundred Languages of Children

https://books.google.com.br/books?id=VpIJWvfdIewC\&lpg=PP1\&hl=pt-BR\&pg=PP1 - v=onepage\&q\&f=false 
igualmente os países desenvolvidos e os em desenvolvimento. Eles são integrados e indivisíveis, e equilibram as três dimensões ${ }^{4}$ do desenvolvimento sustentável.

(ONU, 2015).

Tal universalidade alcançada pelos ODS reafirma os resultados das grandes conferências e cúpulas globais, que discutiram e definiram bases para o desenvolvimento sustentável e visam ajudar a catalisar processos de adequação em instâncias diversas, inclusive escolas, por meio do "espírito de solidariedade global reforçada" e "com a participação de todos os países, todas as partes interessadas e todas as pessoas." (ONU, 2105). Além disso, a Agenda 2030 conta com a Meta 4.a, que inclui o espaço físico escolar:

"Construir e melhorar instalações físicas para educação, apropriadas para crianças e sensíveis às deficiências e ao gênero e que proporcionem ambientes de aprendizagem seguros, não violentos, inclusivos e eficazes para todos" (PNUD, 2015, p. 86).

As atenções às demandas ambientais urgentes são evidentes, globais e crescem incessantes. O conceito Escola Sustentável, portanto, se apresenta como um caminho inexorável e iminente para a exemplificação ética e pedagógica da correta relação homemnatureza às mais novas gerações em seus próprios contextos.

\section{Apresentação}

O espaço escolar sustentável como educador, foi definido como tema ao constatar dois aspectos importantes ao longo desta pesquisa: uma baixa produção de conteúdos nacionais acerca do assunto - oficiais ou não oficiais, acadêmicos ou não - e um progressivo número de programas disponíveis ao redor do mundo voltados para o objetivo comum de incorporar a sustentabilidade nas escolas - para que elas passem a ensinar a sustentabilidade por meio do próprio exemplo.

São programas que levam a comunidade escolar a se reunir em torno das questões ambientais, humanas e econômicas acerca da sustentabilidade em sua instância escolar no que tange assuntos pedagógicos ou administrativos; trazem luz ao seu autoconhecimento sobre esses contextos e promovem a partir dessa conscientização uma listagem de itens a serem atendidos, mas também o processo de transição para o conceito Escola Sustentável nas escolas, sem desconsiderar seus ideários, contextos etnológicos ou aspectos idiossincráticos ${ }^{5}$, bem como sua realidade material.

Cada um desses programas traz enfoques próprios, abrangências que variam e raios de atuação diversos, o que demonstra ser oportuno um levantamento dessas contribuições e de 
outros conteúdos acerca do assunto a fim de reunir e organizar os aspectos até hoje contemplados e obter o estado da arte do que é possível chamar de Escola Sustentável.

\title{
Problema
}

Escolas novas podem ser planejadas em todos os aspectos desde o princípio, mas as existentes podem ter sido concebidas e construídas de forma alheia às demandas que hoje os estudos da sustentabilidade revelam.

Independente de sua solução arquitetônica, a edificação escolar, mesmo com o movimento diretivo de tais programas rumo à sustentabilidade, ainda se nota frequentemente utilizada como meio passivo para o ensino e seu potencial educador desconsiderado pelo projeto político-pedagógico (PPP). Soluções paliativas de uso e conservação improvisadas, imediatistas e sem planejamento permanecem tornando-o desconfortável, ambientalmente inadequado, pedagogicamente antagônico aos valores ético-ambientais ensinados em sala de aula e, portanto, distante do conceito Escola Sustentável pretendido.

As escolas são mencionadas na introdução da NBR 5674:1999, norma brasileira que trata da manutenção de edificações, como um dos equipamentos que comumente sofrem negligência em sua conservação:

\begin{abstract}
A omissão em relação à necessária atenção para a manutenção das edificações pode ser constatada nos freqüentes casos de edificações retiradas de serviço muito antes de cumprida a sua vida útil projetada (pontes, viadutos, escolas), causando muitos transtornos aos seus usuários e um sobrecusto em intensivos serviços de recuperação ou construção de novas edificações. Seguramente, pior é a obrigatória tolerância, por falta de alternativas, ao uso de edificações cujo desempenho atingiu níveis inferiores ao mínimo recomendável para um uso saudável, higiênico ou seguro. Tudo isto possui um custo social que não é contabilizado, mas se reflete na qualidade de vida das pessoas.

Economicamente relevante no custo global das edificações, a manutenção não pode ser feita de modo improvisado e casual. Ela deve ser entendida como um serviço técnico, cuja responsabilidade exige capacitação apurada. (ABNT, 1999, p. 2)
\end{abstract}

A falta de qualidade de vida e bem-estar, tão importantes em espaços de uso coletivo, quando em escolas, pode gerar um custo social ainda maior, dada a referência deficitária que se adquire com essa vivência logo nos anos de escolaridade, além da ampla gama de impactos negativos sobre o processo de aprendizado desencadeada a partir do desconforto físico. Harb, Elhaggar e Sewilam (2019) ao afirmarem que "estruturas ineficientes construídas com materiais que consomem muita energia e funcionam com combustíveis fósseis dão a impressão de que a energia é barata, o meio ambiente não deve ser protegido e os recursos naturais são abundantes", dão um recado especialmente aos gestores escolares sobre a mensagem invertida que negligências sobre o espaço físico escolar transmitem. 
Ampliar a percepção sobre o ambiente e gerar melhorias na sua qualidade e conforto são funções do profissional arquiteto. Porém, torná-lo simultaneamente alinhado ao conceito da sustentabilidade demanda um amplo trabalho de levantamento de dados ambientais, sociais, culturais e econômicos da instância escolar, o que pode limitar ou dificultar esse movimento de transição para a sustentabilidade junto às escolas, caso essa função seja delegada apenas ao arquiteto ou outros profissionais, sem a participação e, principalmente, engajamento dos atores da comunidade escolar ${ }^{6}$.

No entanto, nem todo profissional arquiteto contratado ou terceirizado para realizar adequações ambientais e espaciais em uma escola existente pode se dispor a tal levantamento ou ter essa área de interesse ou ainda outros motivos adversos, como falta de oportunidade ou até de permissão para se aproximar intimamente da comunidade escolar para que possa realizar o trabalho, havendo o risco dos contextos culturais, sociais, ambientais e materiais, quando ali já construídos, acabarem desconsiderados por soluções eventualmente arbitrárias ou desconexas, que possam prejudicar funcionalidades em qualquer aspecto ou mesmo a identidade da escola.

Por outro lado, se a própria comunidade escolar buscar um caminho de autoavaliação, como alguns dos programas atuais incentivam, embora seja um exercício bastante salutar, sem a parceria do arquiteto ou outros profissionais qualificados, pode se tornar uma tarefa difícil e complexa, por conta de roteiros extensos e em alguma parte técnicos, ou se tornar parcial, por conta de limitações de conhecimentos em procedimentos adequados para a sustentabilidade.

Portanto, a fusão entre ambas forças - arquitetos/ profissionais de outras áreas técnicas e comunidade escolar - torna-se ideal, como alguns programas pregam.

\section{Justificativa}

Assim, parece ser clara a necessidade de um instrumento condutor de mão-dupla, em formato de guia, tanto para esses mesmos profissionais poderem conduzir com objetividade um levantamento em edificações escolares onde se pretenda elaborar planos de adequação aos princípios da sustentabilidade ou outras providências necessárias a serem executadas dentro dos critérios da sustentabilidade, como também e inversamente permita à comunidade escolar autoavaliar sua estrutura de forma abrangente e assim munir-se de um programa balizador para

\footnotetext{
6 Ao longo do período extenso e intenso de convivência diária estabelecido com a instância escolar da experiência pregressa já mencionada, foi obtido muito mais que um levantamento físico: hábitos, idiossincrasias, preferências, escolhas, princípios e valores também foram assimilados. Sem a percepção desses traços de identidade não teria sido possível atingir tão rapidamente a comunidade, como será relatado adiante.
} 
profissionais que oportunamente são contratados para intervenções físicas de diversos teores no espaço escolar, incluindo adequações para obter melhorias segundo padrões de sustentabilidade. O instrumento, com princípios pautados no conceito Escola Sustentável, pretende fomentar o trabalho conjunto e multidisciplinar, orientando ambos interlocutores a buscarem as recíprocas parcerias conforme o caso: os profissionais a buscarem os atores da comunidade escolar para os tópicos que exijam reflexões e questionamentos internos e a comunidade escolar a buscar os profissionais para avaliar os tópicos que exijam conhecimentos técnicos ou planejamento espacial.

Ao se verificar o perfil completo e sistêmico dos potenciais e demandas ali existentes - humanos, materiais, espaciais, ambientais, econômicos - ambas as partes poderão se apoiar com segurança em um contexto pré-estabelecido, sem que os valores da instância escolar sejam infringidos com soluções que venham a ser propostas, mas sim fortalecidos e valorizados pelas mesmas.

Inspirada em Malaguzzi (1998, p. 88, tradução nossa), que descreve o processo anterior ao da implantação do programa Reggio Emilia em escolas como um "reconhecimento sobre todos os recursos humanos, ambientais, técnicos e culturais [...] para obter uma visão completa da situação", a partir da percepção de seu próprio espaço físico, esse exercício de autoavaliação poderá exercitar e estimular a visão sistêmica da comunidade escolar, ampliar o seu autoconhecimento, comprometimento, pertencimento e a transversalidade pedagógica por meio da apropriação desse meio ambiente de forma ética, consciente, responsável e interdisciplinar - insumos todos indispensáveis à educação da sustentabilidade.

\section{Objetivos}

O objetivo deste mestrado profissional é definir, portanto, um contorno global do conceito Escola Sustentável e elencar seus princípios universais a serem adotados no produto final deste mestrado profissional: o Guia de Princípios da Escola Sustentável. Esse instrumento pretende facilitar e simplificar a localização dos potenciais e demandas em sustentabilidade na instância escolar, tanto pela comunidade escolar e seus gestores como por profissionais por ela contratados. Os alinhamentos que desse instrumento se revertam, poderão favorecer a transição das escolas para o conceito Escola Sustentável, movimento global que cresce há décadas visando à instância escolar realizar valores teorizados em sala de aula acerca da sustentabilidade, consolidar tal conceito por meio da sua incorporação em hábitos sócioeconômico-ambientais conscientes e continuados dentro da própria comunidade e, dessa forma, 
empoderar e capacitar as novas gerações e futuras à solução de problemas complexos em direção ao equilíbrio entre esses valores.

Alguns objetivos específicos complementam o propósito deste trabalho:

a) favorecer o entendimento das vertentes das ciências ambientais aplicadas ao contexto físico escolar, tendo em vista diálogos e aplicação a contextos diversos de educação, de forma que possa ser replicado;

b) incentivar o diálogo horizontal entre o Espaço Escolar Sustentável e o Projeto Político Pedagógico (PPP) em escolas de educação básica, visando conjugar elementos pertinentes à sustentabilidade e comuns nessas duas instâncias;

c) buscar o perfil etnográfico e idiossincrático de cada instância escolar nas soluções em questão de forma a evitar padronizações dissociadas ao seu contexto ou ideário e assim promover o sentido de pertencimento, a preservação de sua identidade e a consciência sobre o uso e conservação das suas instalações.

\section{Questões de pesquisa}

As indagações que orientam esta pesquisa partiram da problemática original já colocada, frequente em instâncias escolares. Resultaram em questões investigativas (Tabela 1), que permitiram insumos à pesquisa.

Tabela 1 - Questões de pesquisa

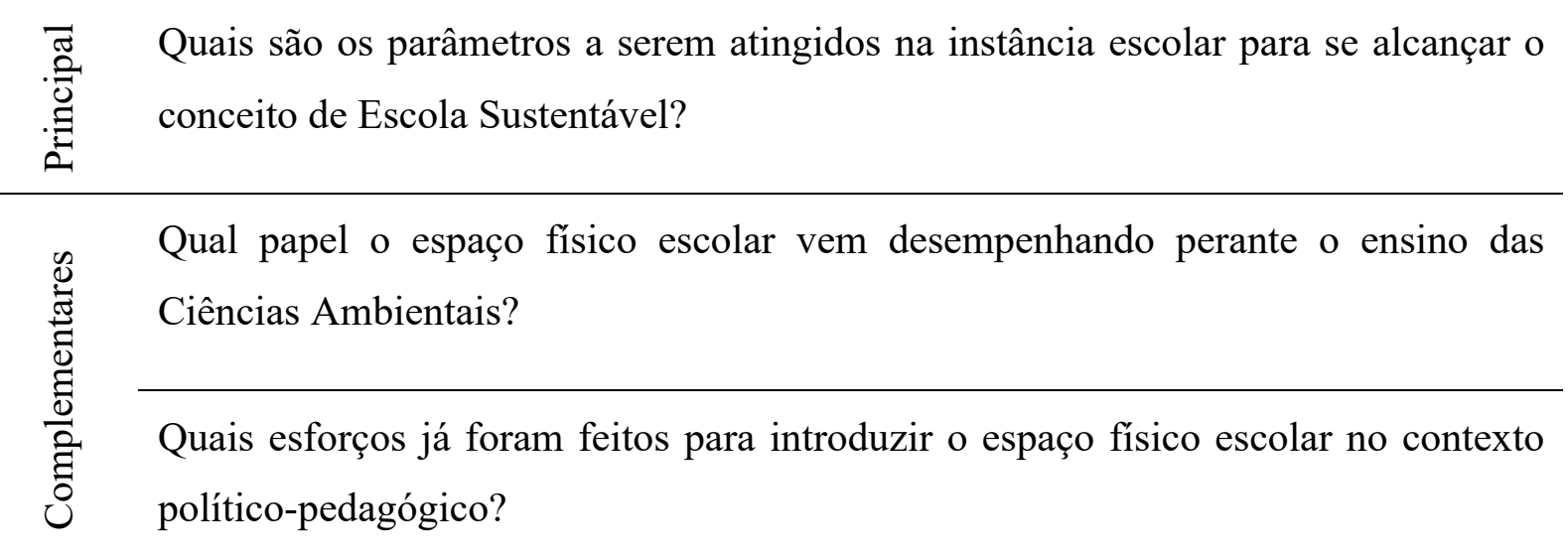

Fonte: Yara Santucci Barreto, 2019.

\section{Metodologia}

A metodologia de pesquisa científica de análise documental e bibliográfica com análise de conteúdo foi adotada para se obter um contorno do conceito Escola Sustentável, bem como para buscar respostas às questões de pesquisa. Literaturas nacionais e internacionais 
foram adotadas para a construção de uma visão global do conceito. Um capítulo deste trabalho, como veremos a seguir, foi dedicado à descrição dos aspectos metodológicos desse tipo de pesquisa e dos procedimentos adotados para a coleta de dados.

\section{Estrutura do Texto}

A presente dissertação de mestrado está organizada da seguinte forma:

No Capítulo 2, um relato de experiência pregressa em instância escolar na cidade de São Paulo traz o contexto sobre o qual este trabalho se origina e em cuja práxis também se baseia.

O Capítulo 3 concentra a metodologia científica adotada, sua teoria, reflexões e aplicabilidades ao tema de pesquisa, bem como demonstra os procedimentos adotados para alcançar os resultados desta pesquisa.

O Capítulo 4 previamente apresenta o contexto histórico da Educação Ambiental (EA) e da Sustentabilidade, de onde tudo parte. Sobretudo demonstra como foi selecionado o referencial bibliográfico e constrói a fundamentação teórica, onde a pesquisa define suas bases e as investigações da pesquisa se desenvolvem.

O Capítulo 5 traz como resultado um contorno do conceito Escola Sustentável e o produto que integra este mestrado profissional, o qual naquele se baseia.

O Capítulo 6 vem compartilhar ponderações e conclusões. 


\section{RELATO DE EXPERIÊNCIA}

Anos antes desta experiência acadêmica, a oportunidade de atuar intensivamente por quase dois anos como profissional especialista em arquitetura sustentável e bioecológica na gestão de uso e conservação sustentável do espaço físico de uma escola particular de ensino básico com 800 alunos em bairro da zona oeste da cidade de São Paulo - ter convivido diariamente com a sua comunidade e executado diversas ações de adequações ambientais e espaciais em sua estrutura física - trouxe novo significado ao meu trabalho como arquiteta e inquietações, que esta pesquisa veio resgatar.

Um projeto de arquitetura bioclimática por mim desenvolvido entre junho e novembro de 2012 para atender a uma demanda emergente de sobreaquecimento em três salas de aula do bloco Fundamental I deu origem a um relacionamento profissional que se ampliaria para uma convivência diária junto à sua comunidade em desmembramentos de atividades e aprendizados que somariam motivação a este presente mestrado e convergiria para um propósito próprio de futuramente realizar uma pesquisa voltada a implantação do conceito da sustentabilidade em espaços escolares, como neste momento se dá.

Uma legenda de caracteres com base no esquema dos 3 pilares da sustentabilidade (Figura 1) situada sempre na lateral direita dos textos e tabelas ao longo deste relato - à parte as críticas que o modelo do desenvolvimento sustentável vem recolhendo pela sobreposição do aspecto econômico da visão desenvolvimentista em detrimento do socioambiental (REDCLIFT, 1993; BARONI, 1992) - vem buscar a intenção original de equilíbrio equânime entre os 3 sistemas principais e suas intersecções e facilitar a identificação das aplicabilidades do conceito de sustentabilidade ao longo das atividades realizadas, bem como adicionar uma lente a mais de observação.

Figura 1 - A equanimidade sustentável entre os 3 sistemas principais e suas intersecções

(S) - SOCIAL

(A) - AMBIENTAL

(E) - ECONÔMICO

(SA) - SOCIOAMBIENTAL

(SE) - SOCIOECONÔMICO

(EA) - ECONÔMICO-AMBIENTAL

(SU) - SUSTENTÁVEL

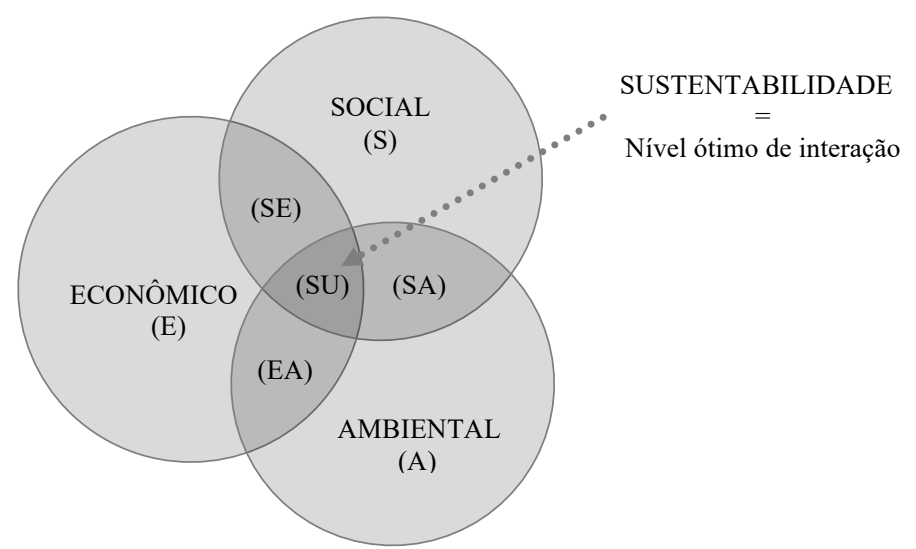

Fonte: Yara Santucci Barreto, 2019 
Para identificar com maior facilidade os resultados e consequências de ordem prática ou comportamental que as ações de intervenções de adequação sustentável realizadas provocaram sobre a comunidade em questão, os textos correspondentes serão enquadrados em molduras como esta.

\subsection{UMA PRAÇA SUSTENTÁVEL ELEVADA - JUNHO A NOVEMBRO DE 2012}

Alguns procedimentos profissionais preliminares de levantamentos fotográfico e métrico, reuniões com o diretor administrativo e pedagógico para obter escopo das necessidades e desejos da comunidade por ele expressados, além de visitas para observação de seu uso e ocupação geraram insumos ao desenvolvimento desse primeiro projeto de intervenção arquitetônica para uma adequação ambiental pontual.

Tratava-se de três salas de aula em pavimento térreo do bloco infantil com laje de cobertura sobreaquecida por 6 horas diárias de incidência solar direta e por um revestimento inadequado recém-instalado para aproveitamento dessa cobertura para fins recreativos e pedagógicos (Foto 1).

Foto 1 - Situação original do espaço sobre laje de cobertura das salas de aula

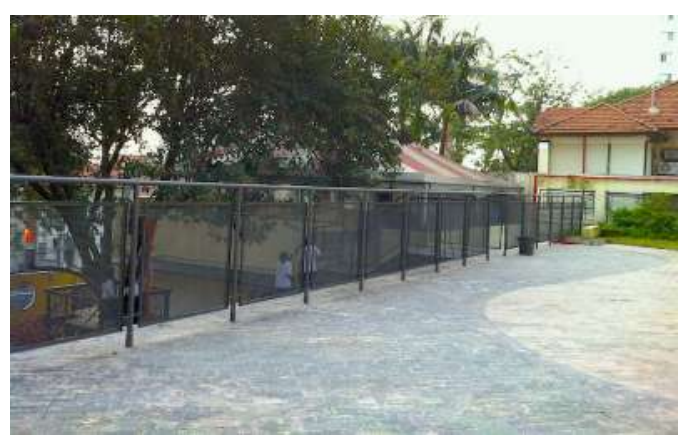

Fonte: Yara Santucci Barreto, 2020

Um anteprojeto, precedido por diagnóstico climático e análises técnicas do local, propôs corrigir os problemas apontados e tornar esse espaço, que foi chamado de Praça Sustentável (Imagem 1), uma referência ambiental de caráter pedagógico para a escola, sujeito a explorações contextualizadas de temas como sustentabilidade, biodiversidade e ecobiologia por meio de soluções afins, tais como:

a) adotar o conceito de reversibilidade de materiais empregados;

b) uso de técnicas ecoeficientes e materiais reciclados para sua construção;

c) materiais de reuso para construção de floreiras e mobiliários; 
d) construção "descarte-zero" por meio de soluções pré-fabricadas ou modulares; (SE)

e) uso e conservação comunitários com economia de recursos;

f) miniecossistema com espécies paisagísticas próprias para atração de borboletas, joaninhas e outros insetos, pássaros, garantindo a auto adubação natural por meio da própria decomposição de flores e esterco desses animais;

g) comedouro para pássaros;

h) mini horta comunitária;

i) muro verde como absorvente acústico e beneficiador para microclima;

j) coleta de águas pluviais para rega e lavagem do espaço;

k) lixeiras para descarte seletivo;

1) minhocário para compostagem de resíduos orgânicos dos lanches e adubação periódica das espécies cultivadas e jardins;

m) abrigar palestras e workshops acerca das teorias e práticas sobre todos esses tópicos permitindo a capacitação continuada dos alunos para a preservação desse espaço e de seu conceito. A solução arquitetônica (Imagem 1) daria a essa praça versatilidade de usos, viabilização em todas as épocas do ano e devolveria conforto termoacústico para as salas de aula situadas sob ela.

Imagem 1 - Anteprojeto da Praça Sustentável

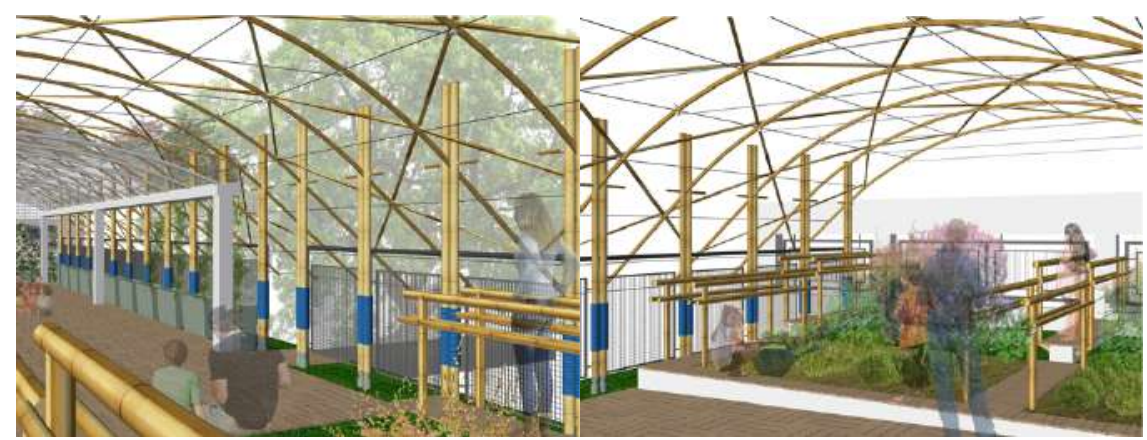

Fonte: Yara Santucci Barreto, 2020

Tal projeto foi submetido à apresentação e análise por uma mesa composta pelo diretor e quatro coordenadores pedagógicos, onde trocas mútuas somaram algumas sugestões, que acolheram a nova alternativa físico-pedagógica com clara satisfação e os seus aspectos assimilados como frentes para contextualização pedagógica. Propuseram-se a desenvolver novos conteúdos a partir da disponibilidade do novo espaço, compactuando integralmente com a proposta. 
Sendo uma escola com regime de gestão participativa, tanto projeto como orçamento foram ressubmetidos, desta vez aos representantes de funcionários, pais e alunos, que igualmente o aprovaram em assembleia. Sequencialmente, reuniu-se na própria escola em novembro de 2012 os fornecedores envolvidos para as programações de execução, que ocorreria em prazo restrito e determinado. Mas o impedimento da execução desse projeto veio com o número de ocupantes almejado ao final pela escola - entre 80 à 100 pessoas - o que exigiria um investimento significativo em reforço estrutural, dada a localização suspensa sobre estruturas antigas, segundo cálculos elaborados e opiniões técnicas obtidas.

Embora a não realização de um desfecho executivo, duas sementes brotaram dessa experiência inicial: 1) a autorrevelação de uma linha condutora para a futura pesquisa já almejada apoiada então no potencial pedagógico do espaço escolar e que ora deságua neste mestrado profissional e 2) uma percepção mais aguçada por ambas as partes sobre as necessidades e demandas de outros ambientes físicos da escola. Nessa ótica, diálogos conduziram-me a uma função de gerenciamento de uso e conservação sustentável, com fins de mapeamento de problemas, diagnóstico das necessidades e execução de soluções segundo graus de prioridade.

Foi solicitado "posto de trabalho interno para que o convívio com a escola revelasse com clareza suas demandas específicas", como apresento em carta-proposta de abril de 2013 aceita pelos mantenedores dessa cooperativa escolar, já pressupondo a necessária aproximação da comunidade, como este recorte reforça:

[...] proponho ouvir e compor parcerias com todos os segmentos da escola [...], tendo como objetivo trabalhar sobre dados atuais e otimizar custos a partir de soluções planejadas.

Essas parcerias tendem a ampliar as inter-relações pessoais dos alunos com os demais segmentos da escola, o engajamento com ela, a consciência sobre preservação e uso das suas instalações, bem como a diminuição da expectativa de soluções imediatistas em prol de resultados consistentes e duráveis. (informação pessoal $)^{7}$.

\subsection{RELATÓRIO E MAPEAMENTO DE USO E CONSERVAÇÃO SUSTENTÁVEL (RMUCS) - MAIO DE 2013}

No mês seguinte, foram iniciados os trabalhos profissionais de observação geral do uso dos espaços físicos escolares pela sua comunidade com o objetivo de identificar e elencar demandas de intervenção física em todo o estabelecimento - fossem elas geradas por mau uso ou má conservação dos espaços e equipamentos, por carência de planejamento espacial ou ainda 
por deficiências em conforto - que gerassem prejuízos em algum grau ao exercício das atividades escolares.

A observação dos usos pela comunidade dos ambientes coletivos de acesso permanentemente aberto - portaria, pátios, sanitários, cozinha, cantina, sala dos professores, informática, bibliotecas, quadras esportivas, parque de areia, anfiteatro, xerox - era diariamente livre. Os ambientes de uso coletivo de acesso restrito foram observados repetidas vezes quando desocupados - salas de aula, salas de artes, auditório. Os ambientes de uso privativo de acesso restrito foram observados uma ou poucas vezes na presença de seus usuários - diretoria, coordenações, financeiro, almoxarifado.

\subsubsection{METODOLOGIA DE TRABALHO}

Entrevistas, observações, anotações e levantamentos fotográficos com fins de registro das demandas encontradas compunham a rotina diária de trabalho. Ao final de cada dia, com as informações ainda frescas em mente e consulta ao registro fotográfico do dia, a organização do conteúdo era feita em arquivo digital, bem como sua análise diagnóstica e de soluções respectivas possíveis (Figura 2). Esse ritmo se estendeu por 3 meses de trabalho, até que toda a escola fosse percorrida e as demandas, registradas e analisadas.

Figura 2 - Metodologia de trabalho

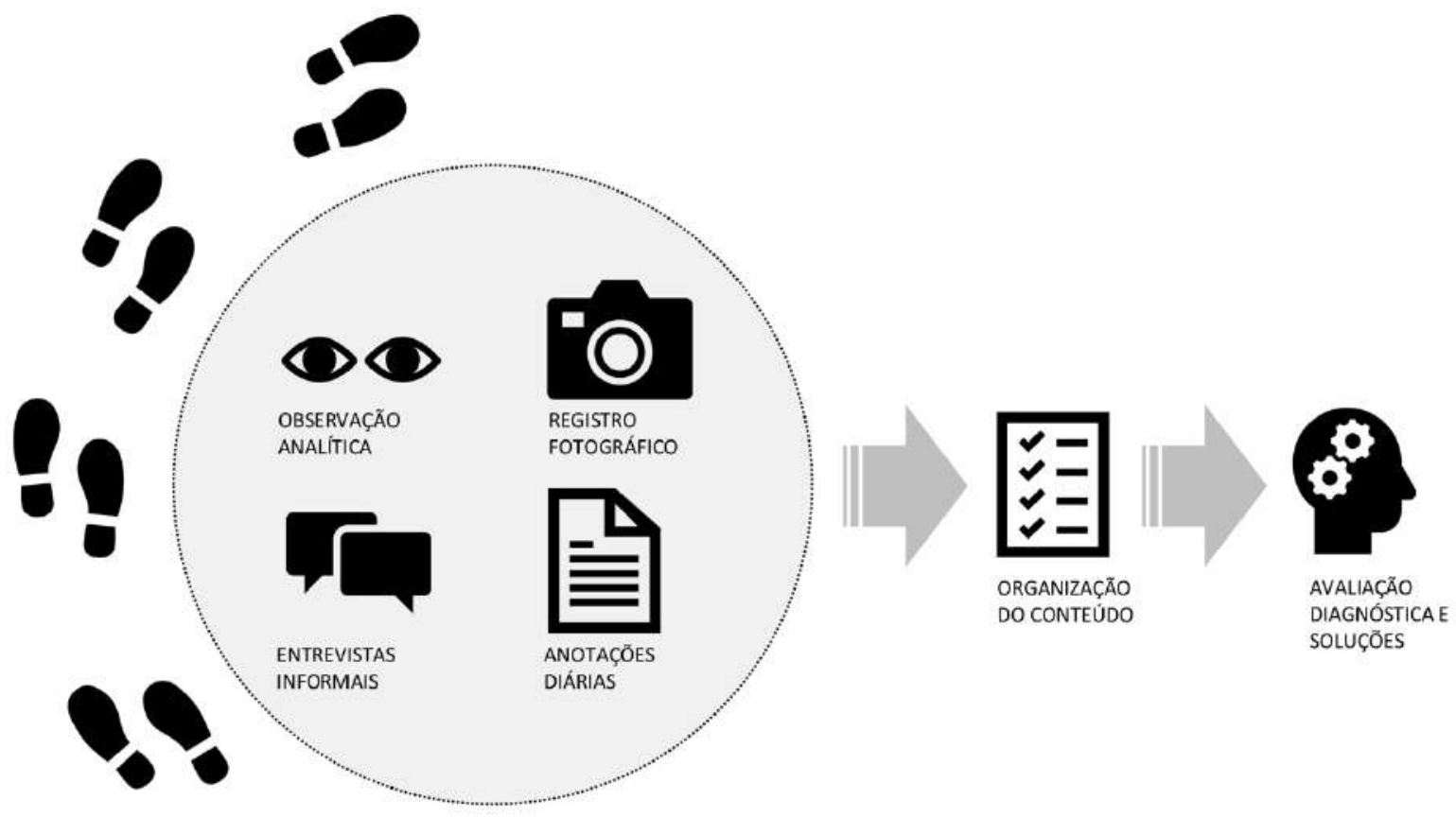

Fonte: Yara Santucci Barreto, 2020 
Antes da descrição de cada um desses momentos diários, vale uma breve pontuação acerca do termo "ambiente":

O conceito de sustentabilidade ambiental é, com frequência, deixado de lado quando
se trata do ambiente construído. A ideia de que o meio ambiente se restringe ao
patrimônio natural é ainda muito presente e limita a compreensão do conceito, já
que ambiente, na verdade, engloba todo o espaço. Qualquer interferência sobre o
espaço construído influencia a qualidade de vida de todos os cidadãos e tem impacto
direto sobre a sustentabilidade ambiental. (BRASIL, 2010, p. 44, grifo do autor).

Este recorte, extraído do capítulo "O espaço físico da escola" da publicação "Processo Formativo em Educação Ambiental: Escolas Sustentáveis e COM-Vida" traz a exata leitura de como o termo deve ser interpretado aqui e em abordagens de mesmo teor.

A rotina incluiria percorrer diariamente os ambientes para uma observação analítica profissional com o foco em como os espaços vinham sendo ocupados e cuidados: quais os seus usuários, como esses espaços os atendiam, seus índices de conforto, suas condições de segurança, suas manutenções vigentes ou pendentes, suas frequências de uso, suas circulações bem resolvidas ou em conflito, mobiliários, acessibilidade, resíduos, higiene, organização ou como os espaços verdes e exteriores eram considerados ou utilizados em seu cotidiano escolar. Os percursos ao longo de um conjunto edificado de $3.600 \mathrm{~m} 2$ em um terreno de $4.200 \mathrm{~m} 2$ abrigando 800 estudantes exigiriam ser feitos em partes.

Ao longo dessas peregrinações de observação, ao detectar uma demanda, eram feitas anotações próprias de dúvidas quanto às suas causas originais ou quaisquer outros registros relevantes a seu respeito. A demanda também era registrada com fotografias abundantes - ora em detalhe ampliado, ora em visão geral - para retratá-la de forma clara e fundamentar seu respectivo relato escrito logo no final do mesmo dia, de forma a salvaguardar as informações quando ainda frescas, já que as entrevistas colhidas junto aos atores relacionados àquela demanda se restringiam a trocas puramente verbais. Seus nomes jamais foram registrados sequer nas anotações, muito menos no relatório final. O foco se restringia a levantar demandas. Ao abordar cada colaborador, nunca foi uma preocupação dar garantias de sigilo sobre seus depoimentos, pois citar nomes não estava no escopo do trabalho. Na NBR 5674 (1999) temos: "são fontes de informações para o sistema de manutenção as solicitações e reclamações dos usuários e as inspeções técnicas.” (ABNT, 1999, p. 4). Eventualmente, alguns demonstravam reservas iniciais quanto às críticas que desejavam expor, mas ao entenderem que meu objetivo enquanto arquiteta não era elencar críticas à escola, mas sim levantar demandas e buscar melhorias para o espaço escolar, contribuíam de forma positiva. Enquanto cenário coletivo e 
compartilhado da comunidade toda, sentiam-se felizes com a oportunidade de inclusão e animados com essa perspectiva de mudança.

Parcerias com atores de todos os segmentos atuantes da escola - alunos, professores, funcionários de manutenção e limpeza, porteiros, inspetores, cozinheiras, bibliotecárias, funcionários técnicos, coordenadores e direção - foram compostas com o objetivo de compreender as causas das deficiências que iam sendo identificadas, ou por eles apontadas, de agregar conteúdo informativo e de fundamentar dados. Essas trocas verbais foram feitas com 40 pessoas do corpo citado, exceto alunos, que foram inúmeros - dos ensinos fundamental I, II e médio - e sempre numa abordagem de mão-dupla, espontânea, muito dinâmica e livre, em momentos ora mais, ora menos fugazes, conforme a situação no dia-a-dia escolar ou perfil individual. Já nas entrevistas, sempre informais, realizadas no próprio posto de trabalho respectivo de cada ator e com duração média de 15 minutos, era sistematicamente colocada a simples pergunta "o que você acha que pode ser melhorado neste espaço físico?", referindo-se ao âmbito espacial respectivo a cada interlocutor, no sentido de dar voz à comunidade como um todo, indiscriminadamente, para expressar espontaneamente tudo o que subjetivamente lhes parecesse importante ressaltar enquanto carência espacial para a boa execução de suas funções específicas e dessa forma perceber-se num movimento engajado de contribuição e soma de benefícios físicos para a escola - papel este que estimularia a qualidade desses dados. A postura de transparência ao informar logo no início de cada entrevista sobre o propósito do trabalho, mais a informalidade da condução verbal, mais o teor propositivo da questão formulada e também o acolhimento isento de julgamentos das contribuições dariam a neutralidade necessária ao ambiente dialógico e favoreceriam o avanço da coleta de dados.

Todas essas aproximações permitiram colher dados que construiriam bases daquele momento e também antecessoras, em que muitos problemas se originaram, de forma a se obter um cenário real e completo, sem o qual não seria possível buscar diretrizes certas e objetivas para solucionar as demandas encontradas. Tais contribuições representaram balizas fundamentais para orientação das propostas de soluções das carências ou deficiências físicas, que dia após dia foram sendo encontradas nos diversos ambientes do espaço escolar.

Como já foi dito, essa rotina possuía o objetivo primeiro e único de gerar o Relatório e Mapeamento de Uso e Conservação Sustentável (RMUCS) do estabelecimento escolar como um todo. Sua função seria balizadora para a gestão das intervenções físicas que no espaço escolar se aplicariam, segundo parâmetros emergenciais, corretivos ou preventivos, a partir de sua conclusão e compartilhamento com a comunidade. 
Entretanto, tal rotina logo viria a ser interrompida no início de junho, para as providências de projeto e orçamento de uma primeira obra de ações corretivas solicitada em caráter emergencial para ser executada no mês seguinte. Em agosto, após ter atendido e concluído tais demandas urgentes, a rotina de mapeamento seria retomada, como este relato apresentará adiante.

\subsection{AÇÕES DE ADEQUAÇÃO - FASE I - JUNHO A JULHO DE 2013}

Essa arritmia dos processos de trabalho de correções espaciais revelaria a fragilidade que o antigo funcionário de manutenção predial da escola já vinha sofrendo há anos no cumprimento de sua agenda cotidianamente abalada por um sem-número de solicitações diárias de correções emergenciais e cumulativas. Essa mesma irregularidade temporal refletirá neste relato, inevitavelmente, de forma que em junho de 2013 seria feita a guinada para essa intervenção física emergencial com o propósito de atender a demandas situadas no setor dos ensinos Fundamental II e Médio, envolvendo infraestrutura hidráulica de esgoto e pluvial prevendo respectivamente adequação e revitalização com formatação piloto de banheiros e drenagem de pátio para eliminar riscos de novos e graves alagamentos, ações essas a serem executadas ao longo do mês de julho, recesso escolar. Uma análise ampliada pela escuta à usuários desses espaços - alunos, coordenador, professores, funcionários de manutenção e limpeza - estendeu a revitalização para o pátio contíguo aos sanitários, área exterior de grande fluxo em recreios e com importante papel na socialização, mas desprovida de acolhimento ou conforto e com uma reverberação sonora elevada em momentos de pico de ocupação, gerando reclamações recorrentes da vizinhança. As colocações subjetivas colhidas destacaram problemas técnicos geradores de desconfortos críticos, tais como mau-cheiro, má iluminação, empoçamentos ou alagamentos.

Porém, somente após as intervenções ali executadas se evidenciou à comunidade o potencial físico latente desses ambientes com a sua transformação em um cenário integrado ao contexto escolar, pedagógico e de bem-estar (Foto 2), quais sejam:

Permeabilização integral do pátio externo - Permitir ao invés de impedir a absorção uniforme e contínua da água de chuva pelos $180 \mathrm{~m} 2$ do pátio externo por meio de um sistema drenante, que objetivava a retenção do volume cumulativo das águas pluviais proveniente de outros pátios e telhados ali então despejados. Além de contribuir para a diminuição do descarte das águas pluviais na rede pública, tal solução proporcionaria o retorno da água de chuva para 
o solo, segundo assim exige o ciclo da água, eliminando manutenções de grelhas e entupimentos, bem como prejuízos com alagamentos.

Formatação dos banheiros - Equipamentos em boas condições foram reaproveitados, destacando o conceito de reuso, tais como: mictórios, vasos sanitários, válvulas de descarga, assentos, tampos, cubas, portas, divisórias de granilite, dispensers de sabão e de papel toalha. Tubulações substituídas e novas caixas de esgoto herméticas com caimentos corrigidos eliminaram o problema do mau-cheiro. Metais sanitários de toque foram substituídos por eletrônicos com sensores de movimento, garantindo a higiene, a eliminação do desperdício de água e a redução de seu consumo. Luzes seriam melhor distribuídas por iluminação linear difundida pelo próprio teto, com sensores de movimento para eliminar o desperdício energético das luzes recorrentemente acesas. Novo revestimento de material reciclado, ralos lineares reduzindo recortes e facilitando o escoamento, lixeiras bem dimensionadas e acessórios diversos de privacidade, tais como divisórias, mola-hidráulica para portas e trincos duráveis integraram o escopo das mudanças e trouxeram conforto.

Barreira acústica de muro verde - A presença exuberante do muro verde com $3 \mathrm{~m}$ de altura trouxe o elemento natural para junto da comunidade e impactou o ambiente com $20 \mathrm{~m}^{2}$ de área verde vertical onde antes eram paredes de blocos de concreto. A absorção sonora de ruídos do pátio de recreio beneficiou a vizinhanças e a própria comunidade escolar. Dez novas espécies de folhagens e floríferas de baixo enraizamento e pouca exigência hídrica deram diversidade biológica e maior vitalidade por períodos mais longos, minimizando os custos com manutenção. O conforto térmico e atmosférico resultante de uma maior umidade relativa gerada por evapotranspiração das folhas, compensaram a aridez original do pátio. O sistema de irrigação por gravidade com mangueiras transpirantes de gotejamento alimentadas por tambores armazenadores de águas pluviais dos telhados da edificação adjacente foi todo construído artesanalmente a baixo custo e exposto permanentemente para aprendizagem. (SU)

Foto 2 - Ações de adequação, Fase I: permeabilização do pátio, reforma dos banheiros e muro verde

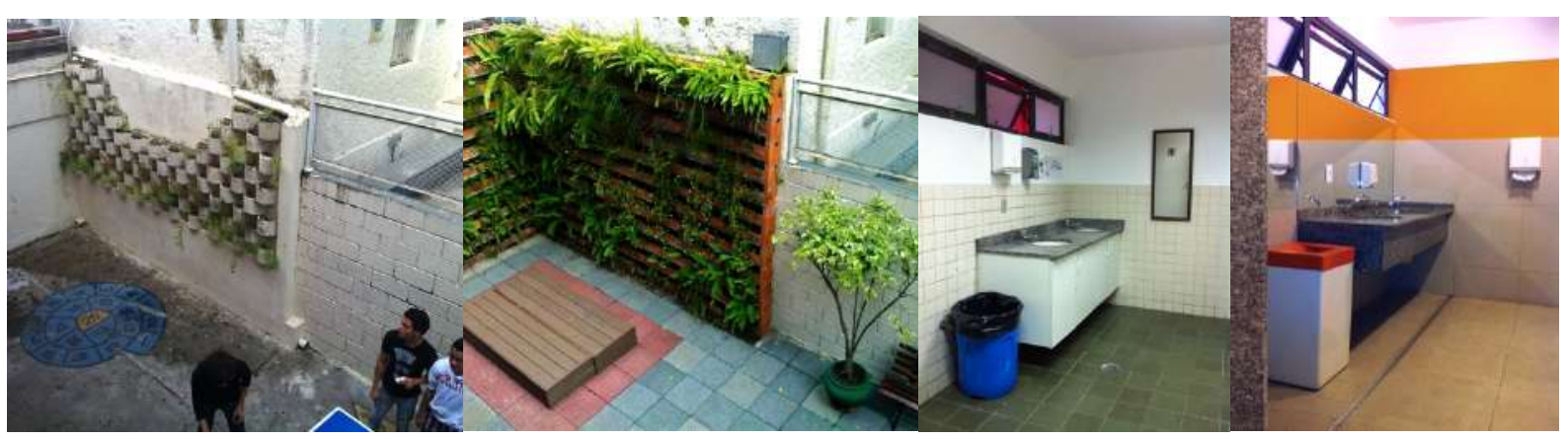

Fonte: Yara Santucci Barreto, 2020 
Revezes previstos e imprevistos como clima desfavorável, instabilidades da equipe civil contratada, impedimentos técnicos, materiais fornecidos sem calibragem de medidas, logísticas interrompidas por terceiros aumentaram o desafio e foram enfrentados durante as obras executivas dessas ações, cuja trajetória de curtíssimo prazo tornaram simultâneos projeto e orçamentos, o que porém favoreceu um sistema integrado de produção que colocou em rede todos os atores do processo.

O retorno da comunidade no início letivo em agosto acabou por favorecer a retomada do processo de elaboração do relatório e mapeamento até então estacionado, uma vez que uma reatividade notadamente positiva aos impactos proporcionados por essas intervenções físicas aguçou as percepções da comunidade sobre o espaço físico escolar e ampliou a margem de apropriações e transversalidades pedagógicas, despertando a curiosidade científica e a discussão de temas ambientais na escola.

Aulas foram ministradas no pátio revitalizado, independentemente do tema, por simples prazer pela proximidade ao verde e ar-livre, o que denotou por um lado a contribuição ao bem-estar da comunidade escolar. Porém, o conjunto dessas novas instalações também foi explorado e investigado pedagogicamente por professores e alunos, resultando em amplos trabalhos escolares em texto, desenho e um vídeo acerca das ciências ambientais desenvolvido por alunos de uma turma do $3^{\circ}$ ano do ensino Fundamental I, que simulava uma reportagem para TV sobre as intervenções físicas de adequação ambiental referentes ao pátio em piso drenante, muro verde irrigado com águas pluviais e banheiros revitalizados e com recursos economizadores (Foto 3). Apresentação de trabalhos passaram também a ser preferencialmente realizadas com o novo "pano de fundo" do muro verde, denotando a reverência prestada ao elemento natural até então ausente nesse cenário físico da escola.

Foto 3 - Apropriações e contextualizações pedagógicas registradas após conclusão da Fase I das adequações sustentáveis

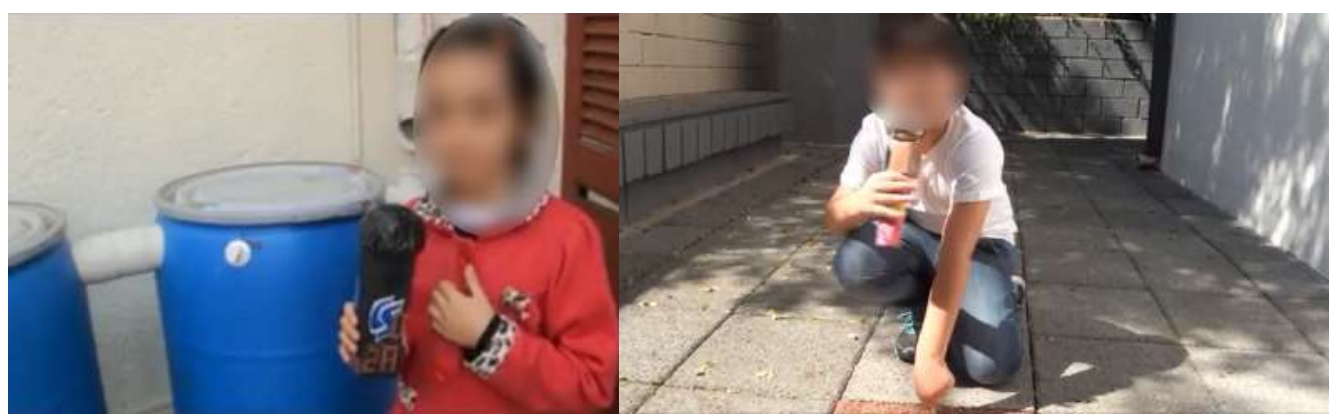




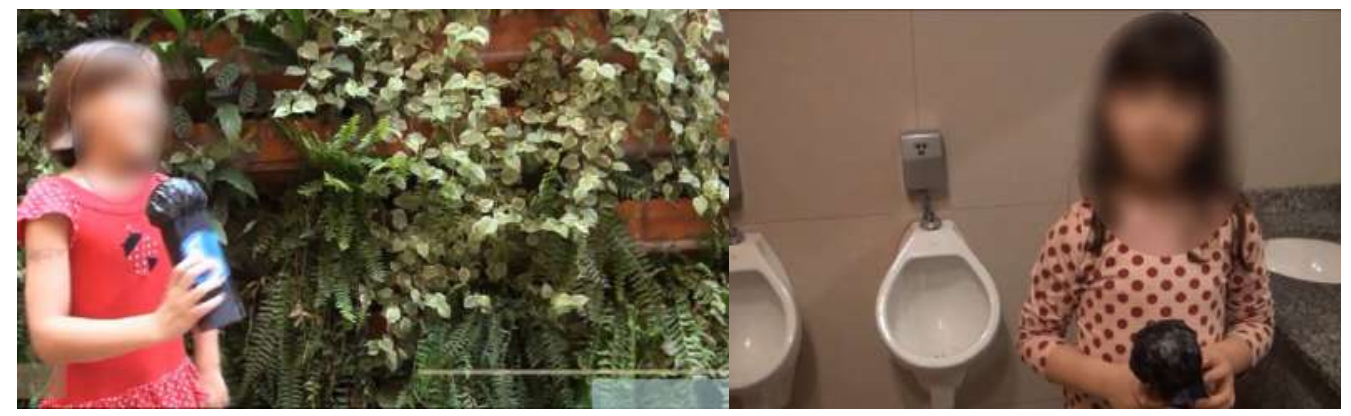

Fonte: Yara Santucci Barreto, 2020

\subsection{RELATÓRIO E MAPEAMENTO DE USO E CONSERVAÇÃO SUSTENTÁVEL (RMUCS) - AGOSTO A OUTUBRO DE 2013}

Retomando, conforme já introduzido, o mapeamento dos problemas físicos do estabelecimento escolar como um todo consistia em nele localizar, registrar e elencar as demandas de desconforto ou risco, desperdício ou prejuízos à escola e aos seus usuários e a partir desse levantamento obtido gerar um diagnóstico de necessidades segundo prioridades emergenciais, corretivas e preventivas, instrumento esse com fins de nortear as propostas de soluções que incluiriam intervenções físicas de adequação dos diversos ambientes do espaço escolar sob critérios de sustentabilidade - apoiados nos pilares ambiental, social e econômico - tais como: durabilidade, baixa manutenção, baixo consumo, reciclabilidade, custo-benefício, segurança, saúde e conforto.

A ação emergencial da Fase I realizada na escola durante o período de férias resultou em uma revitalização calcada nos conceitos da sustentabilidade e gerou impactos positivos sobre diversos âmbitos do cotidiano escolar, como foi visto. Além dos já mencionados, podese dizer que um deles foi o da construção da credibilidade para com o meu trabalho como profissional perante o olhar da comunidade. Proporcionou contribuições mais profícuas que passaram a discorrer a partir de então de uma forma mais facilitada por essa legitimação do papel por mim ali exercido, pois até então ele era indefinido para muitos.

Eu representava uma peça de outro jogo, desconhecido, que gerava curiosidade e por vezes retração. Uma parte da comunidade adulta da escola felicitava minha presença, mas a outra me mantinha invisível aos seus olhos. Já as crianças se aproximavam com curiosidade a perguntarem com característica sinceridade: o que está fazendo? quem é você? por que está tirando fotos disso? aqui vai ser uma horta? por que você está aqui? você está medindo o chão?

Me viam em toda parte falando com todos - da biblioteca ao almoxarifado, da secretaria aos pátios, da cozinha à portaria - o que gerava estranhamento, pois geralmente cada 
pessoa em uma escola "pertence" a um contexto exato ou um "departamento" e dificilmente interage com outros a não ser que isso seja necessário para cumprir sua função. Minha presença, no entanto, era imprevista, indiscriminada, incomum, estranha e mutante.

Essas observações e participações demonstraram notadamente o quanto o ângulo de visão individual sobre o espaço físico escolar restringia-se ao próprio contexto de atuação no mesmo e quanto mais amplo este fosse, maior a percepção. Por exemplo, as contribuições dos funcionários da manutenção geral, responsáveis por reparos e consertos em todos os cantos da escola, por eles percorrida diariamente; e da coordenação financeira, responsável por compras e também gerenciar todas as manutenções. Atores estes familiarizados com uma visão íntima e abrangente do espaço escolar em suas minúcias cotidianas, destacaram-se pela relevância em qualidade e quantidade de dados apresentados.

Foi possível perceber que essa prática abrangente e complexa indiretamente provocava um exercício de ampliação do olhar em cada membro da comunidade para uma visão sistêmica que buscava incorporar os aspectos funcionais, econômicos, administrativos, sociais e ambientais da escola aos político-pedagógicos, convencionalmente priorizados. Era perceptível um certo incômodo, em doses maiores e menores, sob o leque múltiplo de perfis individuais presentes da comunidade.

Mesmo assim, para se obter um inventário completo das demandas físicas, foi preciso somar às apontadas pelos atores consultados da comunidade, outras que se situavam em "pontos cegos" a ela, mesmo aos mais atentos. Surpreendentemente, parte da comunidade especialmente professores, alunos e pais - demorou períodos maiores para conhecer presencialmente as primeiras intervenções realizadas, ainda que de grande porte; já a outra parte - vigilantes, porteiros, faxineiros, funcionários da manutenção, inspetores - comentaram e as felicitaram rapidamente. Lembro-me de uma professora do Fundamental I claramente impactada vir até mim para celebrar o que havia sido executado já há dois meses desde a reabertura da escola, pelo simples fato de seu trajeto diário excluir aquele setor. Isso leva a crer que em escolas de maior porte pode haver atores centrais da comunidade escolar que, mesmo demonstrando claro envolvimento e comprometimento dentro do contexto em que atuam, tenham uma percepção física e espacial parcial, esporádica ou mesmo nula sobre o estabelecimento, em detrimento de seu potencial educativo.

Constatou-se também que intervenções emergenciais dentro de contextos considerados não pedagógicos, de ordem técnica ou relativos à infraestrutura, não eram notadas 
- antes ou depois de atendidas, embora determinantes ao bom funcionamento escolar - exceto pelos funcionários de manutenção (novamente), inspetores e faxineiros, encarregados dessas logísticas. Da observação do dia-a-dia de funcionamento escolar e diálogos realizados com estes atores em específico, foi possível depreender o alto grau de percepção e envolvimento afetivo demonstrado para com a comunidade e espaço físico da escola, muito embora isso permanecesse à sombra das ações e intervenções político-pedagógicas, às quais meramente se submetiam para as devidas viabilizações técnicas, o que me levou a pensar que a valorização dessas participações operacionais poderia trazer luz a uma proposição pedagógica mais abrangente, socialmente inclusiva e rica.

Extratos do relatório de mapeamento de uso e conservação sustentável a seguir exemplificam demandas técnicas e operacionais graves, cujas soluções posteriores, embora partes de um todo e emergenciais em suas perspectivas, foram percebidas e felicitadas apenas pelos pequenos segmentos operacionais da comunidade já mencionados, sem reverberação sobre os demais, alheios tanto aos riscos iniciais como aos benefícios posteriores gerados por esses atendimentos.

O muro de blocos de concreto que divide o pátio do Ensino Médio e o Pátio da Paz suporta boa parte do peso do portão de ferro que corre paralelamente a ele. O portão se eleva até a altura do gradil sobre esse muro, no qual se pendura. A cobertura de policarbonato também se apoia no mesmo gradil, causando sobrecarga de tração no muro, denunciada por frestas de descolamento entre fiadas de blocos.

Frestas verticais denotam uma possível ausência de amarração de ferro na construção desse muro, colocando em risco a estabilidade do mesmo, que tem 2,20 $\mathrm{m}$ de altura e também é contentor de um jardim com espécies de porte adulto.

A refrigeração do $\mathrm{CPD}$ exige temperatura permanente interna do rack em $19^{\circ} \mathrm{C}$, mas o mínimo que atinge é $20^{\circ} \mathrm{C}$. Isso decorre de pequenos vazamentos encontrados no forro e piso, bem como da divisória de Eucatex, imprópria para esse fim por não ter estanqueidade.

O equipamento trabalha além do previsto, tende a se desgastar mais rapidamente e a consumir cada vez mais energia. Além de sua própria durabilidade, pode por em risco o funcionamento do $\mathrm{CPD}$ em caso de falha durante a noite em meses de verão.

A calha sem tela acumula folhas, o escoamento fica prejudicado e aumenta significativamente o peso da cobertura, já sem sustentação segura. A cobertura foi instalada de forma irregular e gerou um caimento contrário das águas pluviais dessa calha, agravando ainda mais o acúmulo de água, gerando também foco de insetos e risco à saúde. Os suportes de fixação da estrutura da cobertura junto à alvenaria se encontravam deslocados, sem pressão, em situação de fragilidade, comprometendo a segurança local. (informação pessoal) ${ }^{8}$

A necessidade de intervenções emergenciais de cunho corretivo como essas e diversas outras ainda mais graves detectadas e apontadas pelo relatório demonstraram desatenção sobre as condições físicas do espaço escolar por parte de sua administração, o que foi confirmado 
pelo desconhecimento dessas emergências e até negligência sobre outras. Mesmo após serem corrigidas, por não terem sido alteradas significativamente em sua aparência, pouco ou nada foram notadas pela grande maioria da comunidade.

Graças ao canal de comunicação construído com a comunidade e, no caso, em específico com os funcionários operacionais, cientes sobre essas situações, foi possível a partir da atuação técnica profissional realizada sobre cada uma, diagnosticar demandas graves e executar diversas ações corretivas. Penso que na ausência desse canal de comunicação, ou da contratação de profissional capacitado, tais informações se perderiam até o colapso ou acidente que cada uma dessas emergências geraria.

Dentre os levantamentos realizados, não apenas demandas preocupantes foram identificadas, mas também agradáveis surpresas, como referências culturais significativas de ordem histórica, ou denunciadas por apropriações e manifestações artísticas, ou de soluções específicas escolhidas pela comunidade, traços esses que balizariam posteriormente os projetos de intervenção para adequações ambientais no estabelecimento (Foto 4).

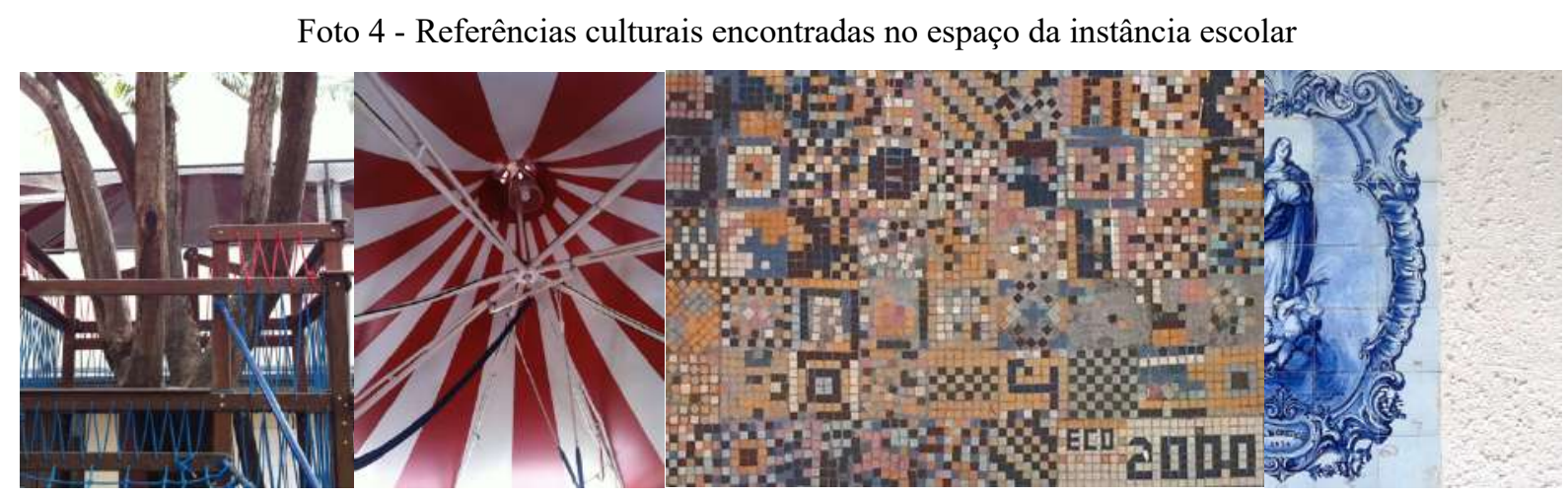

Fonte: Yara Santucci Barreto, 2020

Nada impede que diversos aspectos físicos de uma escola, uma vez apreendidos por sua comunidade, como o produto deste mestrado profissional pretende proporcionar, possam ser contextualizados pedagogicamente, discutidos, ou ainda, dependendo do grau de exigência técnica que demandam, ser geridos coletivamente pela sua comunidade e não apenas por sua equipe operacional. O consumo energético, de água ou manutenção de jardins são apenas alguns exemplos básicos, mas ainda assim pouco explorados. A visão estendida - ou sistêmica favorece o pensamento abrangente com fins sócio-econômico-ambientais que a atual educação pretende formar.

O relatório foi previamente elaborado em formato de texto separado por categorias, conforme o repertório de demandas encontradas, em ordem alfabética, com a descrição de cada 
demanda encontrada e sua respectiva proposta de solução, o que foi apresentado preliminarmente em reunião conjunta com a direção pedagógica, coordenação financeira e de manutenções, a fim de checar viabilidades. A Tabela 2 apresenta as 29 categorias identificadas e resumos das respectivas demandas encontradas:

Tabela 2 - Categorias das demandas - RMUCS

Categoria Resumo das demandas encontradas

1. Acumulações

Consumos excedentes de materiais, mobiliários e equipamentos ociosos;

2. Águas pluviais Calhas, condutores, beirais, coberturas, drenos e grelhas, empoçamentos, infiltrações;

3. Ar-condicionado Equipamentos, sobrecargas e instalações;

4. Bancos Tipologias e distribuição;

5. Bebedouros Localização adequada, higiene, descartáveis;

6. Cantina

Circulação, dimensionamento, equipamentos, instalações, planejamento, organização, iluminação e ventilação;

7. Cozinha Idem Cantina e armazenamentos;

Fornecimento trifásico, quadro de força, aumento de carga,

8. Elétrica estabilização, distribuição, padronização, categorização por cores;

9. Escadas Segurança, acabamentos;

10. Espaços ociosos Planejamento, apropriações e novas atividades pedagógicas;

11. Forros e beirais Infiltrações e reparos;

12. Gás

Botijões substituídos por fornecimento de concessionária, instalações e remoções;

13. Guarda-corpos Instalações, manutenção e segurança;

14. Hidráulica

Caixas d'água e cisternas, desperdício hídrico, consumo e controle de abastecimento; 


\begin{tabular}{ll}
\hline 15. Iluminação & $\begin{array}{l}\text { Qualidade da iluminação diurna e noturna, lâmpadas, sensores e } \\
\text { consumo; }\end{array}$ \\
\hline 16. Incêndio & Revisão, equipamentos e vazamentos; \\
\hline 17. Infiltraçães & Impermeabilização, vedação, isolamento e reparação; \\
\hline 18. Lixo & $\begin{array}{l}\text { Depósito, lixeiras, implantação de sistema seletivo, educação, } \\
\text { logística, destinação; }\end{array}$ \\
\hline 19. Muros & Estabilização e manutenção; \\
\hline 20. Organização & $\begin{array}{l}\text { Pertences de funcionários, utensílios, ferramentaria, } \\
\text { equipamentos, materiais pedagógicos, armários e almoxarifados; }\end{array}$ \\
\hline 21. Paisagismo & Biodiversidade, integração, degradação e manutenção; \\
\hline 22. Pisos & $\begin{array}{l}\text { Permeabilidade, identidade, sinalização, acessibilidade, conforto, } \\
\text { manutenção e segurança; }\end{array}$ \\
\hline
\end{tabular}
23. Desenhos técnicos e Registros históricos e técnicos para consulta, catalogação e documentos digitalização;

24. Quadras esportivas Recuperação, equipamentos, acústica e cobertura;

\begin{tabular}{ll}
\hline $\begin{array}{l}\text { 25. Restauro e } \\
\text { preservação }\end{array}$ & $\begin{array}{l}\text { Janelas e portas de madeira originais de casarão antigo, } \\
\text { arandelas, telhado, planejamento e manutenção; }\end{array}$ \\
\hline 26. Salas de aula & $\begin{array}{l}\text { Planejamento e organização espacial, acessórios, mobiliários, } \\
\text { conforto, acústica, ventilação e iluminação naturais; }\end{array}$ \\
\hline 27. Sala dos professores & $\begin{array}{l}\text { Vazamentos, desperdícios, instalações, acabamentos, metais } \\
\text { 28. Sanitários }\end{array}$ \\
\hline 29. Sistema integrado & $\begin{array}{l}\text { Agenda eletrônica/impressa compartilhada para programação de } \\
\text { de manutenções }\end{array}$ \\
\hline
\end{tabular}

Fonte: Yara Santucci Barreto, 2019

Conforme a NBR 5674 determina, "os relatórios das inspeções devem descrever a deterioração de cada componente da edificação e avaliar a perda do seu desempenho, classificando os serviços de manutenção conforme o grau de urgência [...].” (ABNT, 1999, p. 4). Dessa forma, o texto, após revisado segundo observações, anotações e entrevistas, foi 
integrado ao levantamento fotográfico de mais de 800 fotos, de forma que a elaboração do RMUCS resultou num arquivo eletrônico composto com vasto registro, onde cada demanda física encontrada ao longo do estabelecimento escolar foi descrita e acompanhada consecutivamente de suas respectivas soluções técnicas, a serem programadas. Tal recurso digital, dotado de funções interativas para facilitação de manejo, foi criado com fins de instrumentalizar e empoderar o corpo administrativo da escola proporcionando uma visão abrangente sobre as necessárias ações de adequação física e ambiental sob critério de priorização segundo os graus emergencial, crítico e básico, representados cromaticamente conforme segue, a fim de facilitar a análise:

a) Emergencial: exigem soluções imediatas ou semi-imediatas para controlar processos físicos avançados com riscos iminentes à segurança ou prejuízos.

b) Crítico: alertas a desempenhos irregulares que podem levar a riscos à segurança ou a prejuízos físico-financeiros e exigem reformas.

c) Básico: indicam manutenções periódicas com ou sem projetos integrados.

Foram localizadas ao todo 73 novas demandas relativas ao espaço físico escolar, conforme a Tabela 3 apresenta:

Tabela 3 - Demandas encontradas e atendidas até outubro de 2014.

\begin{tabular}{clccccc}
\hline $\begin{array}{l}\text { Demanda/ } \\
\text { Ação }\end{array}$ & Prioridade & $\begin{array}{l}\text { Integralmente } \\
\text { Executadas }\end{array}$ & $\begin{array}{l}\text { Em } \\
\text { andamento }\end{array}$ & $\begin{array}{l}\text { Parcialmente } \\
\text { Executadas }^{10}\end{array}$ & $\begin{array}{l}\text { Projetadas } \\
\text { para } \\
\text { execução } \\
\text { posterior }\end{array}$ & $\begin{array}{l}\text { Não } \\
\text { Atendidas }\end{array}$ \\
\hline 19 & Emergencial & 7 & 3 & 1 & - & 8 \\
\hline 42 & Críticas & 8 & - & 5 & 3 & 26 \\
\hline 12 & Básicas & 3 & - & 1 & 1 & 7 \\
\hline 73 & & 18 & 3 & 7 & 4 & 41 \\
\hline
\end{tabular}

Fonte: Yara Santucci Barreto, 2019

9 Ações de longa duração para adequações dos sistemas de elétrica e de incêndio envolvendo riscos e exigindo execuções em períodos de recesso escolar ou horários não comerciais.

10 Ações em que a própria equipe administrativa e técnica buscou providências próprias, por vezes provisórias, como forma de mitigar os problemas; ou ações que foram executadas em apenas determinado setor, quando com mais de uma ocorrência no estabelecimento escolar. 
O arquivo digital interativo foi fornecido em mídia CD-Rom à direção pedagógica para análise, que então o compartilharia com quem mais julgasse importante, o que foi feito com a coordenação financeira e de manutenção. Entre deficiências, irregularidades e carências nele elencadas e descritas, mais o movimento previsto pelas soluções nele propostas, o volume informativo apresentado era tal - qualitativo e quantitativo - de modo que a surpresa e o impacto seriam inevitáveis.

Meu papel estaria sendo cumprido, mas sob uma grande tensão interna de compartilhar a desafiadora realidade encontrada, especialmente por saber de inúmeras outras demandas administrativas e pedagógicas enfrentadas no dia-a-dia pelos gestores da escola. A sobrecarga seria grande para todos e assim ocorreu.

De fato, o que se demonstrou a seguir foi um breve período de silêncio e recuo por parte desses atores, provocado inicialmente pelo choque ao conjunto de novas preocupações e ações de intervenção física - diversas em número, tamanho, assunto e prioridade - que enfrentariam dali em diante. Talvez também e além disso, pelo exercício que essa nova postura representava. Exigiria a divisão de atenção, tempo, recursos humanos e financeiros para essas e futuras adequações físicas do espaço escolar a padrões sustentáveis, incluindo-o efetivamente nas discussões e planejamentos escolares.

\subsection{AÇÕES DE ADEQUAÇÃO - FASE II - NOVEMBRO DE 2013 A FEVEREIRO DE 2014}

Consequentemente, logo após tal reação inicial, o RMUCS permitiria conduzir rapidamente a uma avaliação conjunta sobre quais ações emergenciais seriam executadas em próxima oportunidade. Foi possível notar todo um desgaste emocional naqueles atores administrativos, que buscaram, no entanto, a objetividade como saída e traçaram o rumo das próximas intervenções e adequações que aconteceriam no próximo recesso. Seriam executadas adequações emergenciais sobretudo de infraestrutura para correções relativas a desconfortos críticos, riscos à saúde ou integridade física dos usuários, insegurança e instabilidade dos sistemas de elétrica e incêndio. Nessa nova e segunda fase, entretanto, tais execuções não trariam o mesmo cunho atrativo como as de elevado apelo visual e estético da fase anterior, que promoveram visibilidade à atuação administrativo-pedagógica perante a comunidade.

As Tabelas 4 e 5 demonstram essa comparação, sendo que na Tabela 5 pode-se notar que as ações de prioridade emergencial tiveram opostamente uma baixa visibilidade, possivelmente causada por fatores como: 
a) localização em setores mais isolados, distantes das circulações estabelecidas ou fora do ângulo de visão dos usuários;

b) elementos embutidos com pouco ou sem acesso visual;

c) caráter técnico, sem apelos estéticos.

Tabela 4 - Ações de Adequação - Fase I

\begin{tabular}{|c|c|c|c|c|c|c|}
\hline Categoria & Demanda/ação & Localização & $\begin{array}{l}\text { Grau de } \\
\text { Prioridade }\end{array}$ & $\begin{array}{l}\text { Equipes de } \\
\text { Fornecedores }\end{array}$ & \multicolumn{2}{|c|}{ Visibilidade } \\
\hline Águas pluviais & $\begin{array}{l}\text { Permeabilização } \\
\text { dos pátios externos }\end{array}$ & $\begin{array}{l}\text { Fundamental II } \\
\text { e Médio }\end{array}$ & Emergencial & M. o. civil & Alta & $(\mathbf{S U})$ \\
\hline Sanitários & $\begin{array}{l}\text { Formatação dos } \\
\text { sanitários }\end{array}$ & $\begin{array}{l}\text { Fundamental II } \\
\text { e Médio }\end{array}$ & Crítico & $\begin{array}{l}\text { M. o. civil, serv. } \\
\text { em granitos e } \\
\text { vidraçaria }\end{array}$ & Alta & $(\mathbf{S U})$ \\
\hline Paisagismo & $\begin{array}{l}\text { Barreiras acústicas } \\
\text { de muros verdes }\end{array}$ & $\begin{array}{l}\text { Fundamental II } \\
\text { e Médio }\end{array}$ & Crítico & $\begin{array}{l}\text { M. o. civil e } \\
\text { jardinagem }\end{array}$ & Alta & $(\mathbf{S A})$ \\
\hline
\end{tabular}

Fonte: Yara Santucci Barreto, 2019

Tabela 5 - Ações de Adequação - Fase II

\begin{tabular}{|c|c|c|c|c|c|c|}
\hline Categoria & Demanda/ação & Localização & Grau de & Equipes de & \multicolumn{2}{|c|}{ Visibilidade } \\
\hline \multirow[t]{3}{*}{ Acumulações } & Produtos ociosos & Porão e sótão & Crítico & Equipe interna & Baixa & (EA) \\
\hline & Materiais ociosos & Sótão & Crítico & Equipe interna & Baixa & (EA) \\
\hline & Equipamentos & Informática & Crítico & Equipe interna & Baixa & (EA) \\
\hline \multirow[t]{6}{*}{ Águas Pluviais } & Calhas deterioradas & $\begin{array}{l}\text { Quadras } \\
\text { esportivas }\end{array}$ & Crítico & $\begin{array}{l}\text { M. o. civil e } \\
\text { calhadistas }\end{array}$ & Baixa & (SE) \\
\hline & Calhas e telas & Geral & Emergencial & Calhadistas & Baixa & (SE) \\
\hline & Cobertura de vidro & Infantil & Emergencial & $\begin{array}{l}\text { Serralheria e } \\
\text { vidraçaria }\end{array}$ & Baixa & (SE) \\
\hline & $\begin{array}{l}\text { Condutor em fosso } \\
\text { de pilar }\end{array}$ & Almoxarifado & Crítico & M. o. civil & Baixa & $(\mathbf{E})$ \\
\hline & $\begin{array}{l}\text { Condutores } \\
\text { subdimensionados }\end{array}$ & Fundamental I & Crítico & $\begin{array}{l}\text { M. o. civil e } \\
\text { calhadistas }\end{array}$ & Baixa & (SE) \\
\hline & $\begin{array}{l}\text { Toldo de } \\
\text { policarbonato e } \\
\text { calha }\end{array}$ & Fundamental II & Emergencial & $\begin{array}{l}\text { M. o. civil e } \\
\text { calhadistas }\end{array}$ & Baixa & (SE) \\
\hline
\end{tabular}




\begin{tabular}{|c|c|c|c|c|c|c|}
\hline \multirow{2}{*}{$\begin{array}{l}\text { Ar- } \\
\text { condicionado }\end{array}$} & Sobreaquecimento & CPD & Emergencial & Equipe interna & Baixa & $(\mathbf{E})$ \\
\hline & Sobreaquecimento & Sala multiuso & Crítico & Empresa manut. & Média & (S) \\
\hline \multirow[t]{2}{*}{ Beirais e Forros } & $\begin{array}{l}\text { Descolamento de } \\
\text { argamassa }\end{array}$ & Fundamental I & Emergencial & M. o. civil & Baixa & $(\mathbf{S E})$ \\
\hline & Sais em formação & Fundamental I & Básico & M. o. civil & Média & (SE) \\
\hline \multirow[t]{2}{*}{ Elétrica } & $\begin{array}{l}\text { Quadros de entrada } \\
\text { de força e trifásico }\end{array}$ & Depósito & Emergencial & $\begin{array}{l}\text { M. o. civil e } \\
\text { elétrica }\end{array}$ & Baixa & $(\mathbf{E})$ \\
\hline & $\begin{array}{l}\text { Padronizaçao de } \\
\text { Eletrodutos }\end{array}$ & Geral & Emergencial & Equipe elétrica & Baixa & $(\mathbf{S U})$ \\
\hline Gás & $\begin{array}{l}\text { Fornecimento da } \\
\text { rede concessionária }\end{array}$ & Geral & Emergencial & M. o. civil & Baixa & (SU) \\
\hline Incêndio & $\begin{array}{l}\text { Revisão e } \\
\text { vazamentos }\end{array}$ & Geral & Emergencial & $\begin{array}{l}\text { Serviços contra } \\
\text { incêndio }\end{array}$ & Baixa & $(\mathbf{S U})$ \\
\hline \multirow[t]{2}{*}{ Infiltrações } & Lona de cobertura & Circo & Crítico & $\begin{array}{l}\text { Coberturas } \\
\text { tensionadas e } \\
\text { serralheria }\end{array}$ & Alta & (SE) \\
\hline & $\begin{array}{l}\text { Base painel de } \\
\text { ferro }\end{array}$ & Médio & Crítico & Serralheira & Média & (SE) \\
\hline Muros & $\begin{array}{l}\text { Portão x gradil } \\
\text { sobre muro }\end{array}$ & Fundamental II & Emergencial & $\begin{array}{l}\text { M. o. civil e } \\
\text { serralheria }\end{array}$ & Baixa & $(\mathbf{S U})$ \\
\hline \multirow[t]{2}{*}{$\begin{array}{l}\text { Quadras } \\
\text { esportivas }\end{array}$} & Piso e traves de gol & $\begin{array}{l}\text { Ginásio } \\
\text { esportivo }\end{array}$ & Emergencial & $\begin{array}{l}\text { Manutenção de } \\
\text { quadras }\end{array}$ & Alta & $(\mathbf{S})$ \\
\hline & Cobertura & $\begin{array}{l}\text { Ginásio } \\
\text { esportivo }\end{array}$ & Crítico & $\begin{array}{l}\text { M. o. civil e } \\
\text { policarbonato }\end{array}$ & Baixa & (S) \\
\hline Paisagismo & $\begin{array}{l}\text { Jardim junto a } \\
\text { patamar de escada }\end{array}$ & Médio & Básico & $\begin{array}{l}\text { M. o. civil e } \\
\text { jardinagem }\end{array}$ & Alta & (SA) \\
\hline
\end{tabular}

Fonte: Yara Santucci Barreto, 2019

As ações da Fase II foram intervenções de diversas categorias, com planejamentos e orçamentos previamente elaborados numa força-tarefa de grande vulto e elevada carga-horária diária, restrita ao limitado período de recesso escolar. Foram avaliadas e contratadas empresas prestadoras de serviços, envolvendo responsabilidades técnicas elevadas e o gerenciamento logístico de todas elas em modo simultâneo e intensivo. Embora essas intervenções tivessem implicações essencialmente econômicas e ambientais, como a legenda de caracteres lateral permite observar, sendo suas ocorrências dentro de uma escola, não haveria como não 
impactarem positivamente no bom andamento das atividades ali exercidas de convívio social e de ensino e aprendizagem.

Ao longo das execuções das ações situadas nas Fases I ou II, poucos membros dos setores administrativo ou pedagógico da comunidade escolar, excetuando-se aqueles designados a alguma função operacional de suporte à essas atividades, demonstraram interesse ou curiosidade pelo que estava sendo desenvolvido por meio de visitação ou questionamentos. Foi observada como escolha geral pela quase integralidade desses atores a restrição de suas atenções às próprias funções cotidianas. A direção pedagógica e a coordenação financeira permaneceram igualmente centrados em suas próprias atividades, participando apenas quando estritamente necessário para tomadas de decisões. Daí se depreende que embora conscientes e concernentes com as necessidades, a comunidade não necessariamente inclui mudanças efetivas em seu comportamento de rotina e essa morosidade no processo de ampliação da visão abrangente pode dificultar e retardar a incorporação do conceito da sustentabilidade ou mesmo da EA na escola.

Quando da retomada de aulas em 2014, a impressão era de uma certa frustração por parte da comunidade por desta vez haver poucas intervenções esteticamente atraentes com que se surpreender como da anterior, paradoxalmente ao volume e grau de relevância das mudanças e melhorias executadas, como já mencionado (Foto 5).

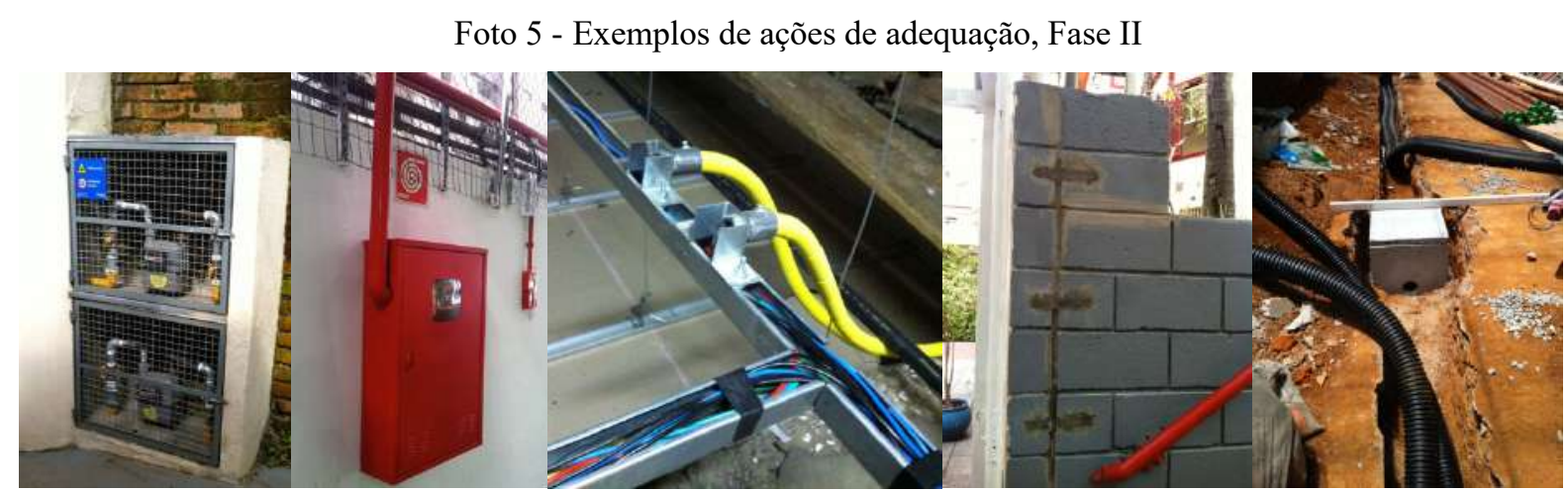

Fonte: Yara Santucci Barreto, 2020

Diante dessas observações colhidas contrapostas ao esforço dispendido, surgiram novas reflexões próprias sobre a importância de se desenvolver uma visão sistêmica da comunidade escolar sobre seu próprio território e do exercício de uma maior comunicação entre si e, no caso, sobretudo sobre os aspectos físicos ali implicados, com fins de combater o alheamento sobre questões relativas ao espaço físico escolar e participar a todos sobre os esforços dispendidos para melhorias de diversos tipos, ainda que possivelmente pudessem 
causar temor nesse momento, dado o acúmulo de emergências de primeira importância encontradas.

\subsection{AÇÕES DE ADEQUAÇÃO - FASE III - MARÇO A OUTUBRO DE 2014}

Após significativos investimentos financeiros nas adequações emergenciais recémexecutadas na Fase II, ou ainda em fase de finalização - como as relativas aos sistemas elétrico e de incêndio, mais complexas e extensas - além de outros compromissos e imprevistos financeiros anunciados pela administração que ainda seriam contemplados, a escola se viu impelida a pausar o avanço de novas execuções de grau crítico e até mesmo emergencial de maior porte levantados pelo RMUCS, até um próximo e indeterminado momento.

Mesmo assim, desejavam-se melhorias que já pudessem ser absorvidas, desde que atendessem a um limite orçamentário acessível e viável. Ainda que algumas dessas ações estivessem dentre as de grau básico na escala de prioridades do relatório, outras implicavam em assuntos críticos por favorecerem a desestabilização física e das atividades cotidianas, mas todas poderiam dar continuidade à evolução da incorporação do conceito de sustentabilidade dentro da escola, em seus âmbitos tanto administrativo como pedagógico, somadas ao alto índice de visibilidade de algumas delas.

Tais demandas foram exemplos de novos "pontos cegos" da comunidade, como antes apontado neste relato, levantadas por meio de observações de uso e ocupação no cotidiano escolar ao longo do desenvolvimento do RMUCS. As três primeiras ações da Tabela 6, complementares entre si, foram planejadas e executadas de forma integrada para atender a um conjunto correlacionado de problemas: o número de bancos existentes era suficiente, mas indevidamente situados em circulações, sob quadros de avisos ou telefones e conflitando usos; outros, isolados e em áreas escuras ou sob sol pleno, acabavam impróprios e ociosos; pátios com carência de bancos e acentos levavam os alunos a ficarem em pé, sentarem-se no chão ou agacharem-se junto à parede para tomarem lanche ou conversar; o distanciamento entre os bancos desfavoreciam o convívio social e suas tipologias estéticas de três cores e formas diferentes e misturadas davam um aspecto de desorganização; espaços ociosos e pouco explorados, amplos, embora incorporados ao cenário cotidiano da escola, imprimiam um aspecto degradado e de abandono; vasos e jardineiras pintados ora de azul, ora de vermelho encontravam-se espalhados sem critério e já sem função paisagística, tanto pela sua degradação física como também das plantas. 
Tabela 6 - Ações de Adequação - Fase III

\begin{tabular}{|c|c|c|c|c|c|c|}
\hline Categoria & Demanda/ação & Localização & $\begin{array}{l}\text { Grau de } \\
\text { Prioridade }\end{array}$ & $\begin{array}{l}\text { Equipes de } \\
\text { Fornecedores }\end{array}$ & \multicolumn{2}{|c|}{ Visibilidade } \\
\hline Bancos & $\begin{array}{l}\text { Tipologia e } \\
\text { distribuição }\end{array}$ & Geral & Básico & $\begin{array}{l}\text { Própria e } \\
\text { equipe interna }\end{array}$ & Alta & $(\mathbf{S})$ \\
\hline Espaços ociosos & $\begin{array}{l}\text { Planejamento e } \\
\text { revitalização }\end{array}$ & $\begin{array}{l}\text { Fundamental } \\
\text { II e Médio }\end{array}$ & Básico & Marcenaria & Alta & $(\mathbf{S})$ \\
\hline Paisagismo & Vasos e jardineiras & Geral & Crítico & $\begin{array}{l}\text { Jardinagem e } \\
\text { equipe interna }\end{array}$ & Alta & (SA) \\
\hline $\begin{array}{l}\text { Plantas e } \\
\text { documentos }\end{array}$ & $\begin{array}{l}\text { Sistema de } \\
\text { catalogação }\end{array}$ & - & Crítico & Própria & Baixa & $(\mathbf{E})$ \\
\hline $\begin{array}{l}\text { Sistema integrado } \\
\text { de manutenções }\end{array}$ & $\begin{array}{l}\text { Agenda de rotinas de } \\
\text { manutenções } \\
\text { preventivas }\end{array}$ & - & Crítico & Própria & Baixa & $(\mathbf{E A})$ \\
\hline
\end{tabular}

Fonte: Yara Santucci Barreto, 2019

Mais uma vez, como ocorrido na fase I, o potencial de exploração pedagógica e de bem-estar se evidenciariam à comunidade somente após essas novas intervenções executadas de forma conjunta, quais sejam:

Um estudo de redistribuição dos bancos existentes e conjuntos de vasos e jardineiras em função da circulação, proporcionalidade de frequência, conforto e do bom aproveitamento espacial, buscou dar destaque e valorização qualitativa para os novos recantos. Para tanto, 22 novos vasos e 12 novas espécies de plantas de baixas manutenção e rega foram adquiridos. No entanto, das 18 plantas encontradas, 11 puderam ser replantadas, somando biodiversidade. Dos 25 vasos levantados, 23 foram revitalizados e impermeabilizados em área isolada da escola, numa força-tarefa que envolveu funcionários de manutenção, alguns porteiros e inspetores voluntários, junto comigo, de uma forma comunitária bastante positiva. Sob a ótica social e participativa, no mínimo, o evento somaria pedagogicamente a professores e estudantes, se pudessem ter percebido tal oportunidade. Inúmeras outras ações como essa, exploradas em prol da participação coletiva, nutrem um senso comum de conscientização e comprometimento sobre o uso e conservação dos bens materiais que compreendem o patrimônio escolar, como Guimarães (1995) iluminou sob a ótica da dimensão ambiental na educação:

"[...] por meio da execução dos procedimentos planejados, o educador/educando deverá construir conhecimentos, possibilitando a criação de novos valores e atitudes na relação ser humano/ambiente, atendendo aos objetivos específicos planejados e 
aos objetivos gerais da EA." (GUIMARÃES ${ }^{11}$, 1995, apud BRASIL, 1998, p. 9899).

A tipologia de bancos perimetrais em recreios, deixando livres as áreas centrais dos pátios para as brincadeiras ativas desse horário e favorecendo a referência espacial global e o contato visual entre as crianças e jovens, seria fundamental para uma apropriação do espaço princípio que foi perseguido pelo projeto.

Um pátio em específico, pertencente ao Fundamental II e Médio, ao contrário dos demais, se encontrava ocioso, embora situado em pleno núcleo da escola. De amplo potencial até então inexplorado, foi requalificado numa praça acolhedora, ganhando piso em deck de madeira plástica, confortável e sem manutenção, delineando assim um novo espaço de permanência, onde conjuntos de vasos revitalizados com plantas recuperadas e selecionadas segundo à insolação local foram posicionados junto a três bancos...

... que logo virariam cinco, trazidos espontaneamente pelos alunos e professores para aulas e discussões ao ar livre, modalidade até então nunca adotada pela escola. Saraus e convivência em recreios também foram observados ali, numa apropriação instantânea muito positiva do novo ambiente.

Já no caso de outro pátio entre a biblioteca e outra edificação do Fundamental II, de uso e ocupação intensos, a carência de acentos levava as crianças a usar a estreita borda de alvenaria de um pequeno canteiro vegetal pouco expressivo ou notado. Em seu lugar, um amplo bancoplataforma também em deck de madeira plástica emoldurou o canteiro - novamente conjugando convivência social e vegetação - e criou um recanto de descanso, oferecendo conforto.

Tal recanto passou a ser disputado na hora do lanche ou, em outros momentos, por funcionários em momentos de intervalo. Neste canteiro e noutro próximo, passaram a ser cultivadas PANCs, plantas alimentícias não convencionais, por professoras e alunos do Fundamental I, o que demonstra que a ação sugerida fez brotar uma apropriação pedagógica desse espaço para práticas ambientais bem como induzir a uma expansão natural das mesmas a outro canteiro similar.

A ausência de acentos junto ao novo muro verde construído na Fase I o tornava um cenário atrativo de aproximação e contextualização pedagógica, como já visto, mas sem recursos de permanência, desmembrando-o parcialmente da rotina escolar. Um simples banco 
em formato de plataforma ou "palco", de mesmo material dos outros decks construídos, requalificou esse ambiente de microclima agradável. Bancos e vasos compuseram outro recanto junto a muro adjacente de blocos, complementando o ambiente de acolhimento (Foto 6).

Foto 6 - Ações de adequação, Fase III: requalificação de pátio ocioso, redistribuição de bancos com incorporação do paisagismo.

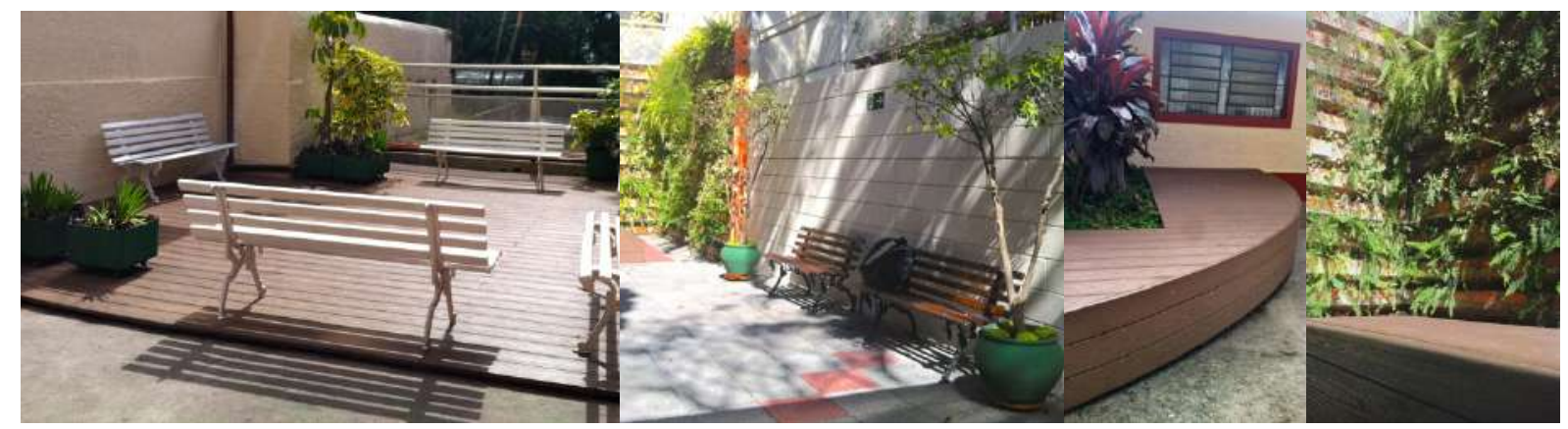

Fonte: Yara Santucci Barreto, 2020

O recanto junto ao muro verde agora complementado pelo novo incremento acabou por permitir a função de acento para o simples usufruto em recreios desse ambiente verdejante, mas também a de plataforma com cenário de fundo vegetal, adotado com frequência em gravações de vídeos de trabalhos escolares, exposições orais, teatrais e discussões teóricas.

Requalificação de espaços ociosos, bancos e vasos de plantas - recursos simples e na maioria já disponíveis, que uma vez planejados de forma integrada podem trazer novas alternativas de atividades pedagógicas e estimular o caráter de pertencimento à comunidade escolar.

Professores e alunos se entusiasmaram na experiência da prática de ensino e aprendizagem a partir das novas opções espaciais abertas e ambos demonstraram intensificar suas relações e compromissos com a escola e suas atividades.

Paralelamente à essas evoluções de alta visibilidade, outras bem menos expostas permaneciam em conflito com suas gestões: muitas vezes funcionários internos, fornecedores ou profissionais contratados para diversos fins de instalações e reformas necessitavam de consultar informações técnicas pertinentes ao trabalho que iriam executar na escola a fim de evitarem arbitrariedades, acidentes ou erros decorrentes e fundamentarem melhor suas ações. Para "reduzir a incerteza no projeto e execução dos serviços de manutenção e auxiliar no planejamento de serviços futuros" (ABNT, 1999, p. 4), como a NBR 5674 coloca, tornava-se prudente e salutar a consulta a documentos e desenhos dos projetos executados na escola. Mas 
a complexidade de acesso a esses registros por se encontrarem ainda em papel, sem catalogação, e armazenados em numerosas pastas separadas por datas, dificultavam consultas por assunto ou por obra, por exemplo; ou pelo simples fato de exigir tempo, comprometendo a qualidade e segurança das novas execuções de serviços diversos.

Já no caso do roteiro de trabalho de manutenções físicas da escola, havia um caderno disponível onde diariamente professores, coordenadores, administradores inseriam continuamente suas solicitações numa lista manuscrita - de consertos ocasionais a correções de grandes problemas - decorrentes de falhas ou de consequências somadas, como depois o RMUCS comprovou ser recorrente. Essa multiplicidade de focos vulneráveis produzia uma demanda progressivamente maior de correções. Os dois únicos funcionários de manutenção buscavam suprir as necessidades de forma quase sempre paliativa, com o ímpeto de atender a todos e de alguma forma zerar o déficit acumulado - o que somente provocava um aumento das deficiências até atingir um volume insolúvel para esses funcionários.

Como a Tabela 6 apresentou, outras duas adequações foram desenvolvidas com o intuito de buscar solucionar esses problemas de forma a organizar, otimizar e sistematizar o funcionamento operacional das manutenções físicas da escola.

Ainda que o ideal fosse a digitalização de todo o acervo existente de desenhos e documentos em papel, e catalogá-los num banco de dados protegido com senha e login, atores do administrativo da escola optaram por um cadastramento categorizado em planilha eletrônica apenas dos desenhos digitais mais recentes.

O recurso permitiu buscá-los com agilidade segundo parâmetros não apenas de datas, mas de assunto, localização, ou até mesmo autor, fornecedor, facilitando pesquisas e alinhando informações necessárias a futuros executores, evitando assim prejuízos. Serviços envolvendo infraestrutura deveriam sempre passar a prever novos desenhos executivos respectivos e incorporar este banco de dados com essas ou outras novas documentações produzidas.

Quanto ao problema gerado pelas constantes ações paliativas mencionadas, adotar soluções definitivas, ainda que demandassem tempo ou verba, seriam a única forma de controlar a acumulação de consertos e de soluções sobrepostas. Um painel eletrônico compartilhado em rede em formato de planilha para apontar atividades emergentes pela comunidade poderia ser desenvolvido como um instrumento para registrar e ao mesmo tempo controlar a qualidade e programar intervenções físicas necessárias com maior precisão. No entanto, novamente atores 
específicos do administrativo da escola optaram por uma agenda impressa de rotinas de manutenções preventivas para preenchimento manual limitado a programar os eventos reparos, serviços terceirizados, compras, etc.

Isso já permitiria que os trabalhos fossem ao menos previstos antecipadamente entre as partes envolvidas, favorecendo execuções completas e definitivas, minimizando gradualmente o acúmulo e o déficit de manutenções pontuais. Embora fossem de grande relevância no combate às correções, preconizando a manutenção preventiva - considerada de suma importância à sustentabilidade do patrimônio físico e das atividades pedagógicas - a reverberação dessas duas adequações não passou do pequeno círculo de poucos atores de setores administrativos e um funcionário central de manutenção.

Essa baixa visibilidade denotou resistência e parcialidade na escolha de uma conduta administrativa dentro do conceito da sustentabilidade, talvez por exigir um esforço individual e também conjunto nessa mudança de paradigma. Foi possível observar na maioria dos atores desses e outros setores operacionais uma dificuldade latente em concordar com a mudança de hábitos em prol da conduta preventiva, ainda que para o bom funcionamento escolar, talvez por falta de uma maior concentração de discussões e acordos internos acerca desse assunto dentro desses círculos da comunidade escolar e não somente em sala de aula. Foi possível constatar o quanto é difícil para essa comunidade escolar, enquanto microcosmo da sociedade, praticar a sustentabilidade em sua totalidade além da teoria, muito embora apresentasse uma vertente já generosa e intencionalmente voltada para essa direção.

Um exemplo que confirmou essa percepção veio em poucos dias subsequentes, quando um dos funcionários de manutenção me consultou sobre qual posição seria ideal para a instalação de holofote de $200 \mathrm{~W}$ que havia sido encomendado para iluminação noturna do principal pátio da escola. Revelou-se assim que a coordenação a que era subordinado permanecia no vício de condutas arbitrárias para solucionar problemas de forma tecnicamente inadequada, que acabariam apenas perpetuados ou somados a novos, enquanto não houvesse a compreensão desse risco e a mudança necessária de conduta em direção à um compartilhamento de decisões com outras partes capacitadas para cada questão.

Questões que tangem a qualidade luminosa espacial, como neste caso, demandam conhecimentos específicos que um profissional do setor luminotécnico ou arquitetônico pode 
suprir com resultados qualitativos seguros, sem causar novos custos com modelos de tecnologia desatualizada com tal consumo energético elevado, desconfortos como ofuscamento, áreas de penumbra, luminância insuficiente ou excessiva, temperatura de cor e outros diversos aspectos.

\subsection{ESTUDOS E PROJETOS PARA AÇÕES POSTERIORES - MARÇO A OUTUBRO DE 2014}

Mesmo que tenham evoluído simultaneamente às ações de adequação descritas anteriormente e também tivessem sido detectadas como necessidades críticas por meio das investigações ao longo da elaboração do RMUCS, vale destacar as seguintes ações das demais realizadas, por não terem sido executadas quando durante minha permanência nessa escola, mas planejadas (Tabela 7).

Tabela 7 - Estudos e Projetos para Ações Posteriores

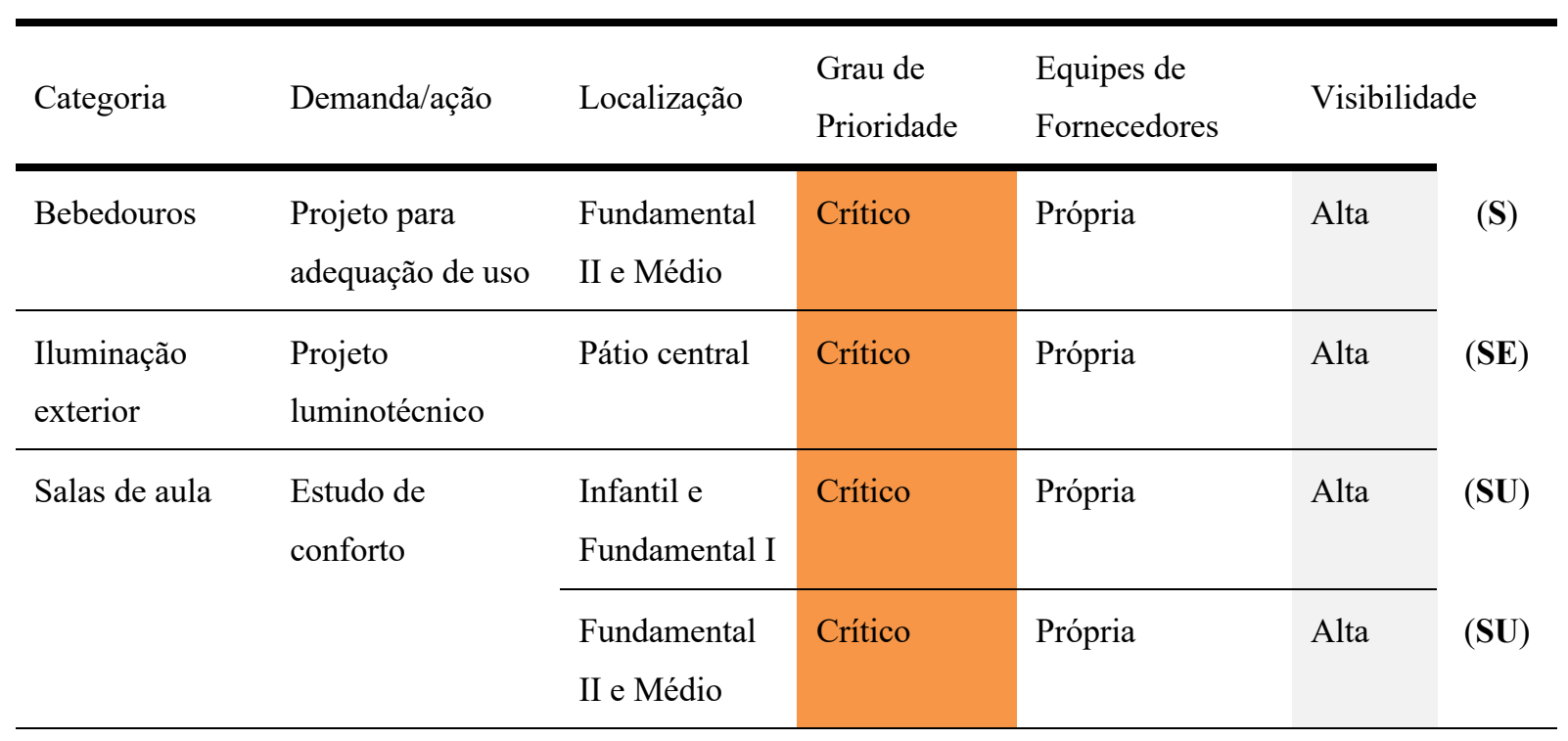

Fonte: Yara Santucci Barreto, 2019

Baseada em mais demandas apontadas pelo RMUCS e aproveitando esse relacionamento íntimo entre minha atuação e essa comunidade escolar, propus ainda esses últimos desenvolvimentos - antes de meu desligamento por questões de mudança de cidade como forma de oferecer meios de promover também nesses espaços nucleares de uma escola, que são as salas de aula, uma maior correspondência espacial e estética com a sua própria identidade. Por meio de estudos de formatação arquitetônica para as necessárias adequações de uso e conforto para os bebedouros e salas de aula, dos ensinos Infantil ao Médio - envolvendo ergonomia, ventilação, iluminação, acuidade visual, acústica e temperatura - foi proposto à direção pedagógica que tais estudos pudessem ser executados na medida da retomada financeira da instituição, mas que já dessem o norte das ações de adequação futuras, o que foi aceito. 
Os bebedouros junto ao edifício dos ensinos Fundamental II e Médio encontravam-se em situação inadequada, incentivando o uso e desperdício excessivos de copos descartáveis. Já o amplo pátio central onde incide o maior número de circulações da escola, em situações de eventos noturnos, exigia uma iluminação bem distribuída sem aumento de consumo.

Foi diagnosticado nas salas de aula do núcleo Infantil e Fundamental I pouco planejamento espacial e portanto falta de valorização visual: carência de acessórios organizadores adequados para armazenamentos de materiais didáticos; mochilas e lancheiras aglomeradas congestionando a circulação; iluminação natural insuficiente, obrigando o uso constante de iluminação artificial mal distribuída, gerando consumo e desconforto; ventilação mecânica de teto, fonte de ruído e de consumo energético, sem solucionar o desconforto térmico. Já o edifício dos ensinos Fundamental II e Médio apresentava fachada sombreada por prédios altos e árvores de maior porte, tornando a iluminação natural deficiente nas salas de aula; ventilação cruzada disponível, mas desperdiçada; persianas verticais de lâminas de PCV rígido geravam ruído quando fechadas, nas ocasiões em que os projetores eram utilizados; elementos construtivos e acessórios em tons escuros prejudicavam ainda mais o conforto luminoso; mesa do professor reduzida; mochilas e bolsas espalhadas no chão e confusão visual (Foto 7).

Foto 7 - Situação existente de bebedouros e salas de aula

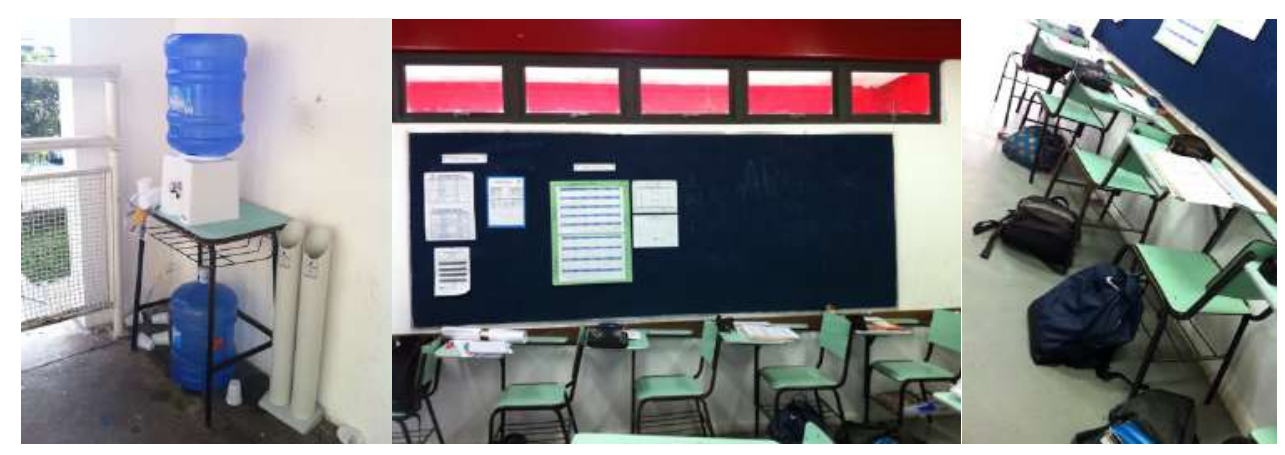

Fonte: Yara Santucci Barreto, 2020

O projeto para nova disposição dos bebedouros segundo circulações e baixa insolação incentivava o uso de canecas em detrimento do uso de descartáveis, enquanto um outro projeto, luminotécnico, para uso noturno do pátio central previu o uso de iluminação LED linear de baixo consumo energético com maior eficiência luminosa, otimizada pelas superfícies refletoras da própria cobertura em abóboda existente, na qual seria instalada (Imagem 2).

O projeto de interiores para as salas de aula do bloco Infantil e Fundamental I previa o aumento de área de iluminação e ventilação naturais com a substituição dos vitrôs por vidros 
amplos e basculantes, de forma a maximizar os vãos de luz e ventilação naturais, elevando o conforto, minimizando consumos energéticos. Embora não fosse possível a ideal ventilação cruzada, as novas janelas dariam um aumento maior que $100 \%$ para a iluminação natural e acima de $200 \%$ para a ventilação, o que devolveria conforto aos ambientes de aprendizado. A simples redistribuição das luminárias existentes eliminaria áreas de penumbra. Acessórios utilitários e pedagógicos, novos e existentes, otimizariam a capacidade de armazenamento do farto material pedagógico e organizariam mochilas e lancheiras. A disposição das carteiras na sala de aula se manteria livre, conforme as atividades pedagógicas demandassem. Alvenaria de tijolos antigos seriam revelados em faixa de mesma altura das carteiras, circundando o ambiente, imprimindo identidade histórica e aconchego. Paineis de feltro escuro existentes seriam revestidos com tecidos coloridos de chita e situados ao alcance das crianças. Lixeiras seletivas para o ensino do descarte correto ganharia um local permanente em cada sala. Uma mola hidráulica manteria a porta fechada, concentrando a atenção nas aulas, já que a ventilação natural das novas janelas a eximiria de manter-se aberta.

No edifício dos ensinos Fundamental II e Médio, a ventilação cruzada, já disponível pelos caixilhos posicionados e dimensionados conforme condições bioclimáticas locais pelo projeto arquitetônico original, voltaria a ser permanentemente adotada e não mais mantida fechada. A condução natural do ar fresco em alta pressão sob as copas das árvores para a zona de baixa pressão mais aquecida pela insolação na fachada oposta através desses caixilhos basculantes, minimizariam desconfortos e uso dos ventiladores. Os elementos escuros seriam revestidos com ecojuta em tom claro e trariam claridade, acústica e aconchego. Algumas dessas superfícies teriam a função de quadro de avisos. A mesma solução de mola hidráulica para a porta e lixeiras seletivas permanentes comporiam a formatação. As persianas rolô em tela screen sem ruídos manteriam a ventilação natural e permitiriam não só absorção acústica, mas o suficiente escurecimento para projeções com data show. Um varal de cabo de aço com pregadores junto à parede principal serviria como expositor de trabalhos de forma ordenada. Nova estação de trabalho para professores com design ergonômico otimizaria a acomodação de livros, equipamentos e seus pertences. Um cabineiro linear se estenderia na lateral e fundos da sala para bolsas e mochilas (Imagem 2). 
Imagem 2 - Projetos futuros: bebedouros, salas de aula Infantil, Fundamental I, II e Ensino Médio

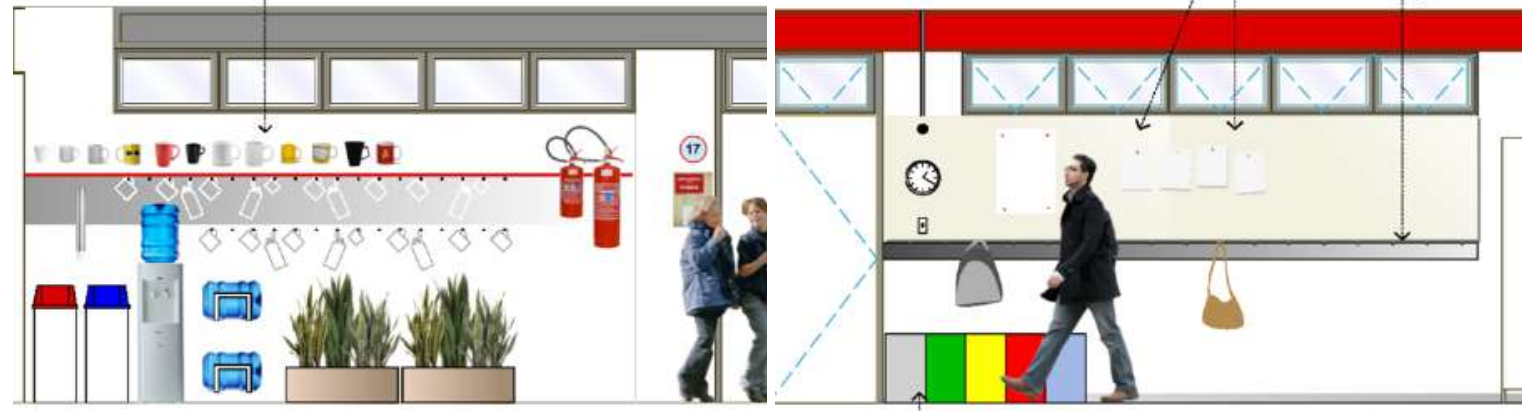

Fonte: Yara Santucci Barreto, 2020

Estes projetos foram apresentados apenas à direção pedagógica, que demonstrou contentamento ao identificar nele traços convergentes aos valores culturais e princípios pedagógicos, além de tecnicamente atender às necessidades elencadas. As contextualizações pedagógicas seriam inúmeras, tais como foram acima descritas, envolvendo análises de consumo energético a partir da economia gerada pelas soluções passivas de iluminação e ventilação naturais, circulação de ar entre áreas de baixa e alta pressão, hábitos conscientes em relação a descartes, além de benefícios à qualidade de ensino e aprendizagem em sala de aula por meio de soluções de conforto acústico e organização espacial.

Uma vez ocorrendo a descontinuidade das minhas atividades nessa instância escolar em outubro de 2014, visitas informais ali realizadas posteriormente puderam demonstrar que a comunidade escolar adquiriu um ritmo quanto a ações em favor da potencialização do espaço físico escolar como instrumento de contextualização pedagógica dos conceitos que a EA e a sustentabilidade preconizam. Tal exercício de abrangência de visão permitiu incorporar ao menos parcialmente seu espaço físico ao projeto político-pedagógico e fortalecer a identidade dessa instância escolar.

\subsection{CONSIDERAÇÕES FINAIS}

Tal relato descreveu todas as caracterizações físicas, materiais e espaciais das intervenções físicas em uma instância escolar e também alguns aspectos etnográficos e idiossincráticos identificados, muito embora possam ser descrições similares ou comuns a outras escolas e, sob essa perspectiva, tornar-se útil no processo de autoavaliação que este trabalho pretende. 
Torna-se importante diante de tal distância temporal rever o que foi vivenciado e executado, o que a Figura 3 propõe resumir:

Figura 3 - Linha do tempo dos trabalhos desenvolvidos

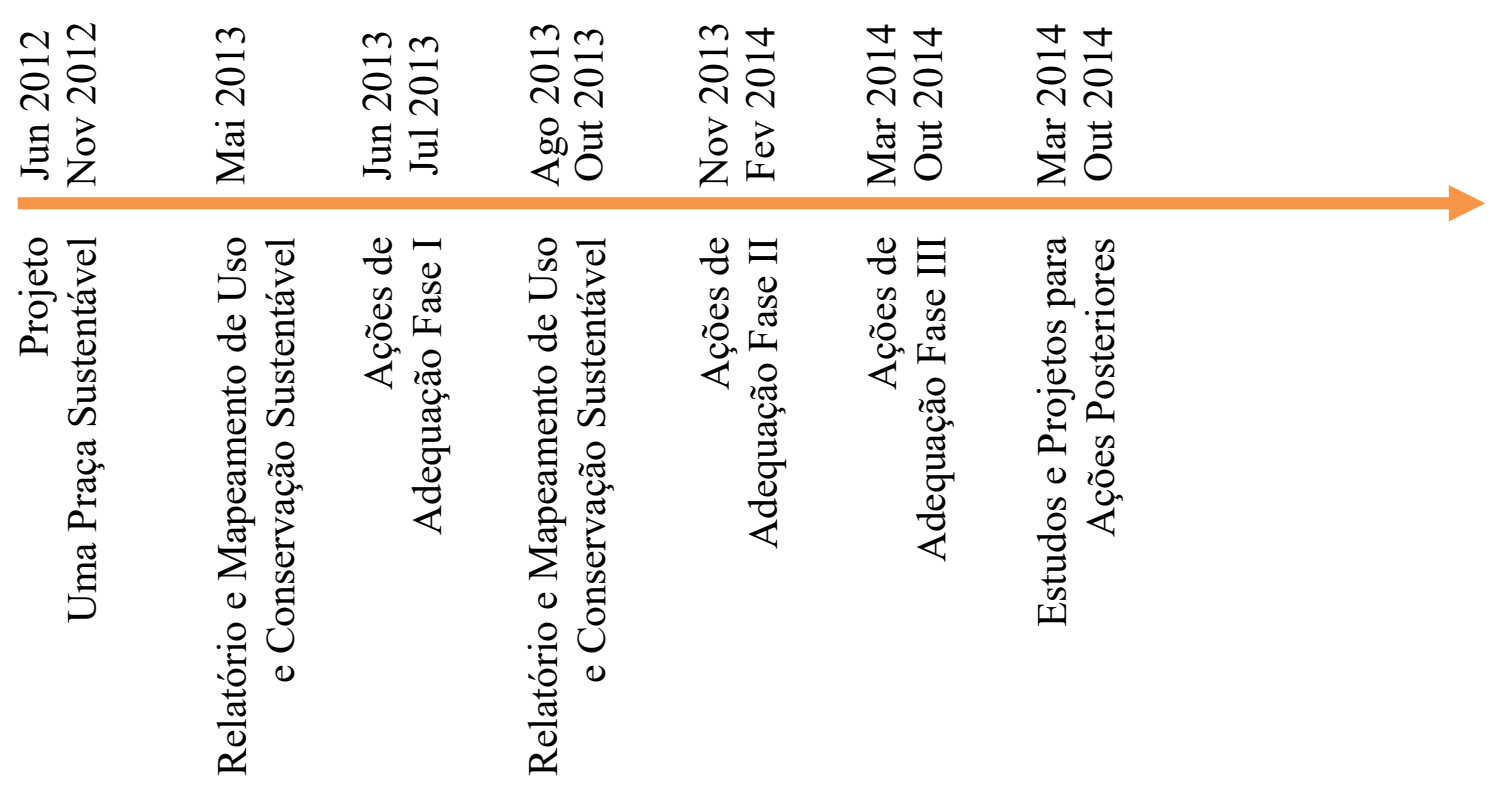

Fonte: Yara Santucci Barreto, 2020

Das 73 ações previstas pelo RMUCS, 18 foram concluídas e outras 14 iniciadas até outubro de 2014, num total de 32 intervenções físicas de adequação executadas ou projetadas partir dele e de seu balizamento, entre novembro de 2013 e outubro de 2014, o que representa $43,8 \%$ no total.

Como foi ilustrado pelo esquema gráfico da Figura 1 no início deste capítulo e como ainda será visto ao longo deste trabalho de pesquisa, é preciso muito mais que adequação ambiental ao espaço escolar para se alcançar o conceito Escola Sustentável, como equivocadamente pode-se julgar. Embora o objetivo do trabalho que acaba de ser relatado se limitasse a melhorias espaciais e ambientais voltadas para o alinhamento com a sustentabilidade, é possível observar (Tabela 8), pelo que a legenda de caracteres procurou apontar, que essas intervenções foram em boa parte além das meramente ambientais e incluíram os outros dois pilares, social e econômico, e suas intersecções - socioambiental, socioeconômico e econômico-ambiental. Elas não tornaram essa escola sustentável, mas a encaminharam para essa direção. O processo foi iniciado e o movimento de transição para o conceito Escola Sustentável, que envolve um conjunto sistêmico de mudanças, poderá ser continuado. 
Tabela 8 - Análise da legenda de caracteres

\begin{tabular}{ccccccc}
\hline$(\mathrm{S})$ & $(\mathrm{A})$ & $(\mathrm{E})$ & $(\mathrm{SA})$ & $(\mathrm{SE})$ & $(\mathrm{EA})$ & $(\mathrm{SU})$ \\
\hline 7 & 4 & 4 & 7 & 11 & 8 & 12 \\
\hline
\end{tabular}

Fonte: Yara Santucci Barreto, 2021

Embora o espaço físico possa representar um bom caminho integrativo e catalizador para o processo de transição para a sustentabilidade na escola, há muito mais a se trilhar para se alcançar o conceito Escola Sustentável, como pretendo analisar neste trabalho.

$\mathrm{Na}$ época em que a experiência relatada ocorreu, ainda quando distante do meio acadêmico e alheia à métodos de pesquisa como os que este mestrado, anos após, me apresentou, é interessante hoje ler André (1984), por exemplo, trazendo históricos de discussões acerca de como o estudo de caso envolve "diversos métodos de pesquisa" - observação, entrevistas, fotografias, anotações de campo, negociações - para a "investigação sistemática de uma única instância" (NISBETT e WATT, 197812 apud ANDRÉ, 1984, p. 51) e "pretende retratar o idiossincrático e o particular como legítimos [por meio do] desenvolvimento de um conhecimento idiográfico do caso, [...] tratado como uma entidade única, singular" (p. 52); ou Thiollent (1986), sobre como aspectos do método da pesquisa-ação, em que a interação "ampla e explícita" entre pesquisador e pessoas, da qual resulta uma "ordem de prioridade dos problemas", que são de "diversas naturezas" e cujas resoluções levam a um aumento de conhecimentos e "nível de consciência" (p. 16) dos atores envolvidos - descrições metodológicas tão próximas ao vivenciado.

Ainda que na época dos fatos deste relato o enfoque fosse profissional e o desejo de um projeto acadêmico embora presente, ainda fosse remoto, surpreendo-me com tais similaridades e delas extraio uma reflexão fundamental:

Como arquiteta urbanista, não me restam dúvidas de que a visão abrangente e sensível desta formação profissional se ajusta à compreensão da complexidade do universo escolar. No entanto, a minuciosa investigação do seu contexto social, material e ambiental da forma como foi neste caso realizada, caso não seja área de interesse do profissional, como é para mim, pode acabar indo além do repertório regular de atividades e competências da classe e sobrecarregar o profissional arquiteto. De forma equivalente, pode inviabilizar trabalhos também de outros especialistas contratados para projetos, consultorias ou execuções em espaços escolares. 
Elencar problemas e elaborar o programa de necessidades geralmente é da parte contratante, embora possa ser perfeitamente compartilhado, quando fruto de consultoria ou acordo ${ }^{13}$, como foi neste caso. Para tanto, tudo o que foi executado nesta instância escolar partiu de um vasto levantamento, como foi visto. Sem tal imersão no contexto diário dessa comunidade escolar e no seu território de convivências, não haveria bases suficientes para o trabalho se desenvolver de forma congruente à sustentabilidade, com intervenções planejadas para formarem um ciclo virtuoso de estabilidade das soluções adotadas, ampliação de repertórios educativos e bem-estar para a sua comunidade. Conhecer a fundo o contexto em que a escola se insere torna-se ponto de partida inerente ao seu alinhamento ao conceito Escola Sustentável, como o pensamento de Gonçalves e Duarte (2006) sobre arquitetura sustentável vem confirmar:

\section{[...] arquitetura sustentável é mais do que tratar de conforto ambiental e energia. Pode-se listar uma série de outros fatores ambientais, sociais, econômicos e até mesmo urbanos e de infra-estrutura. Assim, as premissas para a sustentabilidade da arquitetura são extraídas do contexto em questão e do problema ou do programa que é colocado para a proposição do projeto. Dessa forma, pode-se afirmar que a sustentabilidade de um projeto arquitetônico começa na leitura e no entendimento do contexto no qual o edifício se insere e nas decisões iniciais de projeto. \\ (GONÇALVES; DUARTE, 2006).}

Se tal levantamento de dados que conforma cada instância escolar dentro de seu contexto é ponto de partida indispensável para a implementação do conceito Escola Sustentável, e se esse exercício deve ser elaborado pela parte nele inserida - a própria comunidade escolar - neste momento vale relembrar a justificação desta pesquisa em proporcionar ao gestor e comunidade escolares o exercício de autoconhecimento e autoavaliação da sustentabilidade para a construção ou desenvolvimento de seu próprio perfil de potenciais e demandas existentes - sociais, materiais e ambientais. Tal "planejamento participativo", recomendado por Guimarães (1995, apud BRASIL, 1998, p. 96) a todos os atores da comunidade escolar, seria uma forma de se conhecer a "realidade concreta [da] escola, contexto social, etc., com todos participando de tudo: desde a decisão do que fazer até a execução e avaliação do trabalho".

Souza Santos (1988) já sustentava que a ciência moderna se afastou do cidadão comum e a pós-moderna se reaproxima dele em busca do "senso comum" e da visão real de mundo que julgava ter antes dos "desconhecimentos" que aquela gerou:

[...] A ciência moderna construiu-se contra o senso comum que considerou superficial, ilusório e falso. A ciência pós-moderna procura reabilitar o senso

\footnotetext{
13 Segundo o Código de Ética e Disciplina do Conselho de Arquitetura e Urbanismo do Brasil (2015), dentre as obrigações para com o contratante, "o arquiteto e urbanista deve oferecer propostas para a prestação de serviço somente após obter informações necessárias e suficientes sobre a natureza e extensão dos serviços profissionais solicitados por seu contratante" (p. 8), mas é recomendado "considerar e interpretar as necessidades das pessoas, da coletividade e dos grupos sociais, relativas ao ordenamento do espaço, à concepção e execução das construções, à preservação e valorização do patrimônio arquitetônico, urbanístico, paisagístico e natural” (p. 6).
} 
comum por reconhecer nesta forma de conhecimento algumas virtualidades para enriquecer a nossa relação com o mundo." (SANTOS, 1988).

Dentro desse raciocínio, o resultado da autoavaliação da sustentabilidade que o produto deste mestrado pretende proporcionar às comunidades escolares promoveria os exercícios do senso comum e do planejamento participativo, entre seus atores, em prol do autoconhecimento e maturidade. O produto Guia de Princípios da Escola Sustentável passaria a servir da mesma forma a profissionais arquitetos, ou a outros especialista igualmente envolvidos com intervenções físicas dentro do ambiente escolar, como um inventário contextualizado e programa de necessidades da instância escolar, a balizar seus trabalhos de forma mais objetiva para adequações do espaço físico escolar ao conceito Escola Sustentável, salvaguardando o ideário escolar de deformações indesejáveis e valorizando-o, na mesma proporção. 


\section{METODOLOGIA}

Ao abranger o roteiro a que se propõe de localizar nas literaturas e delas extrair contribuições para delinear o conceito Escola Sustentável, a fim dele extrair a matéria-prima do produto deste mestrado profissional, esta pesquisa se volta neste momento à apresentação da metodologia de pesquisa adotada para tal tarefa - a análise documental e bibliográfica com análise de conteúdo, que conduzirá a investigação e esclarecimento do objetivo central e também específicos a que se propôs.

\subsection{ANÁLISE DOCUMENTAL E BIBLIOGRÁFICA}

A metodologia da análise documental e bibliográfica, adotada para extrair os princípios do conceito Escola Sustentável, vem se apoiar em conteúdos nacionais e internacionais que envolvem o tema objetivamente e estejam diretamente relacionados a ele ou envolvidos significativamente nesse conceito. Vem embasar a investigação científica de como o conceito Escola Sustentável dessas fontes emerge a fim de se obter o estado da arte de seu contorno atual, reunir os princípios encontrados e dessa forma obter o seu quadro mais completo possível.

Conforme Cellard (2008, p. 299), na primeira etapa da análise documental e bibliográfica é feita uma "avaliação crítica [sob] cinco dimensões" - contexto, autoria, autenticidade, natureza e conceitos-chave - comentadas a seguir, de forma a elucidar sobre como a metodologia foi trabalhada sobre os conteúdos selecionados:

Os seus contextos são variados, mas com o aspecto de mover esforços em favor do avanço da EA e da sustentabilidade em comum - programas de políticas públicas; resoluções legislativas de conselhos, negociações de agendas, relatórios de conferências, manuais, leis ou relatos de experiência em educação, são exemplos.

Sobre os autores, configuram-se em três categorias distintas:

a) pesquisadores acadêmicos, cujos interesses são essencialmente investigativos e de cunhos específicos segundo suas áreas de exploração científica;

b) funcionários públicos, que compõem departamentos e coordenações internas de órgãos administrativos, integrantes das equipes técnicas dos Ministérios do Meio Ambiente e da Educação, que se alinham ideologicamente e se reportam às suas gestões, alguns apresentando formações acadêmicas sem maiores expressões ou sem lattes (alguns redatores), enquanto outros apresentam amplo lattes (coordenações) e participações em 
artigos ou livros; e acadêmicos cujas contribuições não apenas se reportam à essas esferas governamentais e aos compromissos destas perante à sociedade que se reporta, mas também a interesses de desenvolvimento integrado nos âmbitos ambiental e educacional, segundo verificado em suas formações, especialidades e experiências;

c) membros de organizações não governamentais com amplas formações em diversas competências técnicas e analíticas, muitas vezes com ampla experiência e carreira no mercado, visando implementos em políticas voltadas ao bem-estar econômico e social ao redor do mundo.

No caso da análise documental de legislações, resoluções, declarações, manuais, agendas ou políticas públicas - embora primários, são documentos oficiais publicados na internet em sites do governo brasileiro e de instituições governamentais e não-governamentais notórias e reconhecidas nacional ou internacionalmente, garantindo a procedência e autenticidade de informações; no caso da análise bibliográfica, sendo em sua totalidade de obras secundárias de dissertações, artigos acadêmicos e livros, publicados em periódicos científicos ou disponíveis em formato digital em portais de periódicos científicos ou bibliotecas virtuais e em bibliotecas universitárias, pode-se considerá-las igualmente fontes de autenticidade e confiabilidade garantidas de informações ${ }^{14}$.

Documentos oficiais nacionais e internacionais, artigos de periódicos científicos e dissertações vêm apresentar uma natureza, em sua maioria, de estrutura formal, especialmente textos oficiais. Já livros, cartilhas, manuais seguem cada qual sua natureza própria, segundo a diversidade dos contextos mencionados e subjetividade dos autores.

A análise metodológica buscou conceitos-chave na lógica dos argumentos ou relatos dos conteúdos documentais e bibliográficos, que contenham contribuições de seus respectivos autores ao tema pesquisado. Em textos oficiais, tais conceitos-chave são mais simples de serem identificados por não terem uma autoria subjetiva, o que torna mais fácil a identificação dos argumentos neles objetivados.

Holsti $^{15}$ (1969, apud LÜDKE; ANDRÉ, 2012, p.42), recomenda adotar unidades de registro que podem ser contabilizadas no texto ou interpretadas segundo contextos em que nele ocorrem: termos, palavras, tópicos, mas também outras formas que o pesquisador julgar

14 Obras secundárias recebem essa terminologia por terem recebido tratamentos científicos posteriores à sua produção original. Obras primárias são documentos originais, sem tratamento científico, a serem analisadas pelo pesquisador. (OLIVEIRA, 2007, apud SÁ-SILVA; ALMEIDA; GUINDANI).

15 HOLSTI, O. R. Content Analysis for the Social Sciences and Humanities. Reading. MA: Addison-Wesley, 1969. 
estratégicos ou relativas aos objetivos de sua pesquisa. Foram incorporadas duas questões investigativas abrangentes, visando orientar tais buscas nos conteúdos, perseguir respostas para as questões desta pesquisa (Capítulo 1) e otimizar a extração de dados das fontes documentais e bibliográficas selecionadas:

a) Quais as contribuições nesta literatura para a construção do conceito Escola Sustentável?

b) Como o espaço físico escolar é citado nesta literatura?

Acerca da análise dos conteúdos obtidos, sob o esclarecimento de Bardin (1977):

Tratar o material é codificá-lo. A codificação corresponde a uma transformação efectuada segundo regras precisas - dos dados brutos do texto, transformação esta que, por recorte, agregação e enumeração, permite atingir uma representação do conteúdo, ou da sua expressão, susceptível de esclarecer o analista acerca das características do texto, que podem servir de índices. (BARDIN, 1977, pg. 103).

Se a unidade de registro "é a unidade de significação a codificar e corresponde ao segmento de conteúdo a considerar como unidade de base" (p. 104), tais recortes se configuram como o alicerce para os procedimentos metodológicos desta pesquisa. A análise limitou-se a levantar e reunir unidades de registros nos textos que contribuem para responder estritamente às questões investigativas, isentando-se de qualquer outro aspecto subjetivo ou ideológico observado na análise de seus conteúdos, que não correspondem ao objetivo deste trabalho.

Além das unidades de registro, algumas unidades de análise, de palavras e termoschave pertinentes ao tema da pesquisa, num exercício contrário, foram previamente elencadas (Tabela 9). Sendo praticamente todos os conteúdos digitais, utilizou-se recurso de busca sobre os textos de tais unidades, com o objetivo de checar a pertinência e abrangência dessas literaturas ao tema de fato.

Tabela 9 - Unidades de análise para busca

\begin{tabular}{lllll}
\hline Escola/ Escola & Espaço/ Espaço & Bem-estar & Espaço físico/ & Ambiental/Meio \\
sustentável & físico & & Ambiente físico & ambiente \\
Sustent* & Constru* & Edific* & Interdisciplin* & \\
\hline
\end{tabular}

Fonte: Yara Santucci Barreto, 2019

Lüdke e André (2012, p. 42) alertam sobre o "rigor" e "dedicação" nesse momento de reunir e analisar todos os dados colhidos com "sistematização e coerência", independente da "forma" adotada para tais anotações. Portanto, escolheu-se criar um modelo para o fichamento dos dados coletados nos textos (Tabela 10) para serem reunidos de forma organizada, onde 
especialmente os conceitos-chave e segmentos de conteúdo com contribuições para as respostas às perguntas investigativas pudessem ser registrados para a facilitação da coleta de unidades de registro neles identificados com grifos próprios e um melhor manejo dos dados.

Tabela 10 - Modelo de ficha

\begin{tabular}{|c|c|}
\hline Referência & \\
\hline Contexto & \\
\hline Autor & \\
\hline $\begin{array}{c}\text { Autenticidade } \\
\text { Natureza }\end{array}$ & \\
\hline $\begin{array}{c}\text { Conceitos- } \\
\text { chave }\end{array}$ & \\
\hline \multicolumn{2}{|c|}{ Quais as contribuições nesta literatura para a construção do conceito Escola Sustentável? } \\
\hline \multicolumn{2}{|c}{ Como o espaço físico escolar é citado nesta literatura? } \\
\hline
\end{tabular}

Fonte: Yara Santucci Barreto, 2019

Contexto, autoria, autenticidade e natureza são dimensões que apresentaram uma variação bastante menor nos textos primários. Dessa forma, permitiram ser apresentados conjuntamente neste capítulo, conforme já feito acima, e, portanto, suprimidos de suas respectivas fichas (Tabela 11).

Tabela 11 - Modelo de ficha - textos primários

\begin{tabular}{|c|c|}
\hline $\begin{array}{c}\text { Referência } \\
\text { Conceitos- } \\
\text { chave }\end{array}$ & \\
\hline \multicolumn{2}{|c|}{ Quais as contribuições nesta literatura para a construção do conceito Escola Sustentável? } \\
\hline \multicolumn{2}{|c|}{ Como o espaço físico escolar é citado nesta literatura? } \\
\hline
\end{tabular}

Fonte: Yara Santucci Barreto, 2019

Por meio do software Excel, tais fichamentos foram organizados para cada título documental ou bibliográfico analisado em guias individuais nomeadas respectivamente com o nome do primeiro ou único autor e ano de publicação, em ordem cronológica, de forma a gerar um banco de dados digitalizado das literaturas selecionadas.

Após essa primeira coleta, seguindo Cellard (2008), Lüdke e André (2012), a segunda etapa de análise consiste na investigação e análise dos dados coletados, o que envolve por sua vez a metodologia da análise de conteúdo: uma vez extraídas dos conteúdos documentais e bibliográficos, as unidades de registro são identificadas segundo os assuntos a que se referem e organizadas em categorias de análise (p. 42, grifo nosso). Bardin (1977, p. 117-118) detalha o 
critério dessa categorização entre "semântico" (pelo sentido comum entre palavras), "sintático" (pela concordância entre as palavras), "léxico" (pelo sentido variado das palavras, "com emparelhamento dos sinônimos e dos sentidos próximos"). Na ocorrência de unidades de registro idênticas e repetidas ou com sentidos próximos, deverão ser consideradas de forma unificada, dentro de sua respectiva categoria; no caso de termos de menor abrangência de significado, suprimidas pelas de maior abrangência, com significado o mais completo possível.

A organização das unidades de registro em categorias se fez por meio de outra planilha utilizando o mesmo software: em uma linha superior fixa, 16 categorias encabeçaram colunas respectivas, pouco a pouco preenchidas por células individuais de cada unidade de registro encontrada, formando um corpo de dados progressivo e deslizante em sentido vertical (Figura 4). Cores identificaram a procedência dessas unidades. Essa configuração foi adotada a fim de permitir com relativa facilidade não apenas a visualização completa em tempo real do painel geral das unidades de registro, mas também seus eventuais deslocamentos de uma categoria para outra, conforme o processo intensivo de análise foi amadurecendo.

Figura 4 - Unidades de registro distribuídas em categorias.

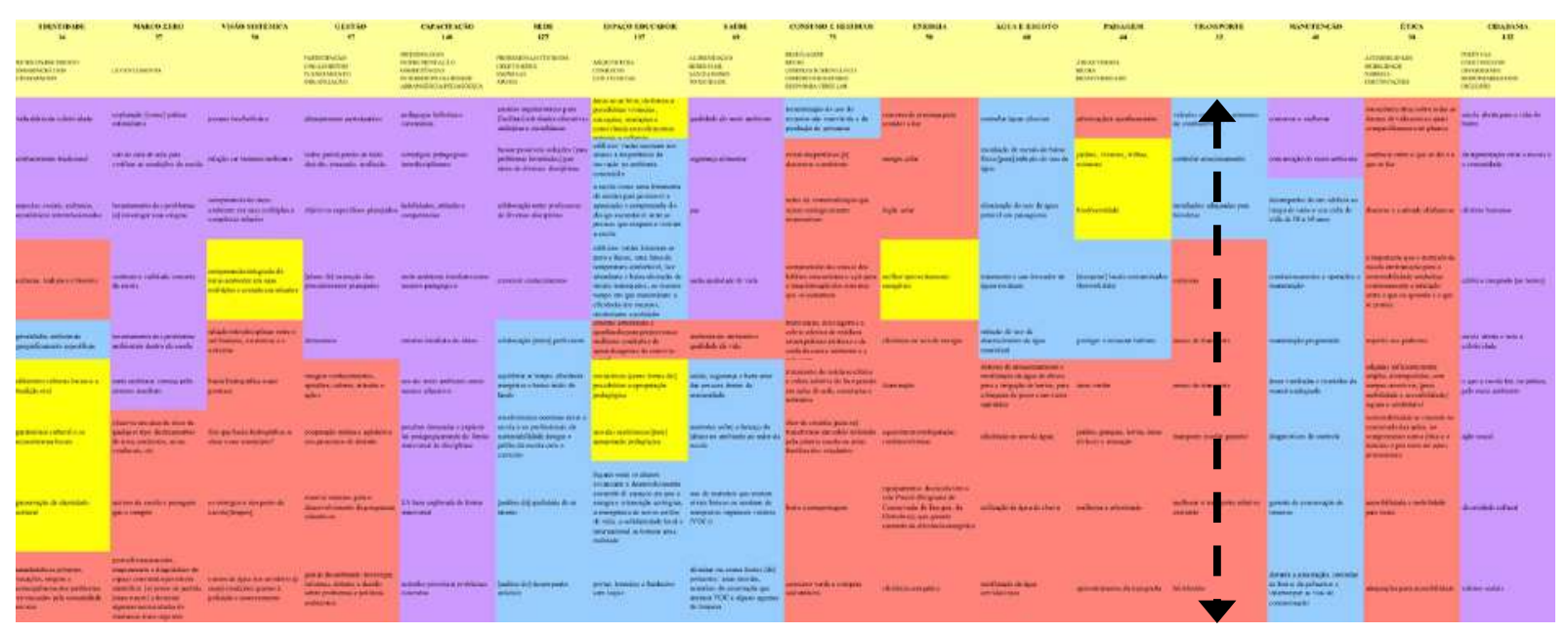

Fonte: Yara Santucci Barreto, 2021

Em suma, na medida em que as literaturas foram analisadas, segmentos de conteúdo representativos das questões investigativas foram sendo localizados nos textos e armazenados em fichas; grifos próprios foram adotados para destacar unidades de registro dentro desses recortes; os assuntos dessas unidades de registro foram sendo identificados e se tornaram categorias; as unidades de registro foram sendo distribuídas conforme a pertinência dentro dessas categorias, primeiramente em estado bruto - antes dos procedimentos de unificação e supressão - e após, já processados, o que será apresentado no capítulo 5 por se tratar de parte significativa dos resultados. 


\section{REVISÃO DE LITERATURA}

A composição do referencial bibliográfico, sobre o qual o embasamento teórico e a investigação da pesquisa acerca do conceito Escola Sustentável se desdobram, partiu de uma revisão sistemática de literatura a seguir apresentada.

\subsection{BASES DE DADOS}

O GOOGLE SCHOLAR proporcionou localizar obras e artigos segundo autores específicos e checar importância das obras segundo o número de suas citações em outros artigos ou livros.

O CAPES PERIÓDICOS por concentrar muitas plataformas científicas na sua busca de forma automática foi usado para testar diversas strings na língua portuguesa e inglesa pela opção Buscar Assunto, bem como salvar essas buscas e organizar as obras selecionadas em pastas. Pela opção Buscar Periódico, área de conhecimento Ciências Sociais Aplicadas e sub área Arquitetura e Urbanismo foram digitados consecutivamente os termos "sustain*", "educ*" e "school", dos quais artigos internacionais atuais e relevantes sobre o tema foram localizados.

Bases de Dados via CAPES: recurso do CAPES PERIÓDICOS onde foi personalizada uma base de busca em dez plataformas de buscas científicas, escolhendo primeiramente como área de conhecimento Ciências Sociais Aplicadas e sub área Arquitetura e Urbanismo, selecionando as que incluíssem em suas sinopses conteúdos convergentes ao tema pesquisado. Resultou no seguinte conjunto: SciELO, Networked Digital Library of Theses and Dissertations: NDLTD, Cambridge Core, Google Scholar, Derwent Innovations Index - DII, Library of Congress (United States Library of Congress - LOC), Directory of Open Access Journals - DOAJ, Duke University Press, SCOPUS (Elsevier), Web of Science - Coleção Principal (Clarivate Analytics).

\subsubsection{CRITÉRIOS DE INCLUSÃO E EXCLUSÃO}

Critérios de inclusão (CI):

- CI 1: artigos publicados entre 2000 a 2020 - período de maior maturidade quanto ao desenvolvimento das pesquisas sobre sustentabilidade, como será visto ainda neste capítulo em uma breve análise sobre a evolução histórica da EA e da sustentabilidade;

- CI 2: apenas artigos revisados por pares foram considerados; 
- CI 3: o título e/ou resumo inclua os termos-chave "Escola Sustentável" ou "Espaço físico escolar", em português ou inglês;

- CI 4: o resumo aborde a integração do espaço físico escolar com outros assuntos objetos desta pesquisa, tais como, o projeto político-pedagógico (PPP), visão sistêmica, gestão escolar, ciências ambientais, sustentabilidade ou desenvolvimento sustentável;

- CI 5: o resumo denote alguma contribuição (abordagem, processo, método, técnica ou ferramenta) em prol da contextualização do ensino das ciências ambientais no meio físico escolar.

Critérios de exclusão (CE):

- CE 1: se dois estudos abordarem o mesmo tópico, o menos completo será excluído;

- CE 2: textos duplicados;

- CE 3: textos indisponíveis na internet.

\subsubsection{STRINGS (ST) DE BUSCA}

Diversas strings de busca foram construídas, ora com as palavras-chave, ora incluindo termos relativos aos objetivos específicos desta pesquisa (Capítulo 1). De cada uma das strings de busca abaixo mantidas, foi possível coletar materiais importantes e pertinentes à pesquisa.

Curiosamente, a string (ST) que levou a conteúdos mais pertinentes e abrangentes, foi a ST 2, que embora inclua apenas o principal termo-chave desta pesquisa, trouxe também contribuições sobre os demais, dentro dos conteúdos por ela coletados com parâmetros atuais ao redor do mundo. A ST 4, buscando conjugar todas as faces desejadas da pesquisa, acabou por desviar para assuntos diversos e alheios a ela (agroecologia, economia solidária ou saúde pública são exemplos). Foram adotados refinamentos de busca por meio da escolha de tópicos dentre os disponibilizados a cada busca pela plataforma CAPES, nessa ordem de preferência: Sustainable Development, Schools ou Education.

- ST 4: (Espaço escolar) AND (Planejamento OR Adequação) AND (Sustent* OR Ecolog* OR Particip* OR Interdisciplinar*) AND ((ciências ambientais) OR (projeto político pedagógico)). Resultados da busca: 503 títulos no total, reduzidos a 72 após refinar o tópico para Educação; 
- ST 3: "escola sustentável" OR "escolas sustentáveis". Resultados da busca: Apenas 12 títulos, apontados entre 2011 até o momento, o que demonstra ser bastante recente e iniciante a produção nacional sobre o tema;

- ST 2: "sustainable school" OR "sustainable schools". Resultados da busca: 817 títulos, reduzidos a 148 após refinar o tópico para Sustainable Development;

- ST 1: ((Espaço escolar) OR (School buildings)) AND (Escola OR School) AND (Etnografia OR Etnography). Resultados da busca: 268 títulos - sem alternativas de tópicos adequados para refinamento, optou-se por selecionar três artigos atuais que atendem ao enfoque que a presente pesquisa demanda. Foi observado que o termo "espaço escolar" foi empregado de forma genérica - sem se referir ao espaço físico escolar, propriamente. Inserir o termo "físico", tampouco resultou em melhores resultados.

\subsubsection{SELEÇÃO DOS ESTUDOS}

Foram escolhidos não apenas conteúdos periféricos acerca da EA e suas legislações, mas também acerca de programas direcionados objetivamente à implantação da sustentabilidade em escolas no mundo atual por meio da educação para o desenvolvimento sustentável (EDS).

A partir dessas buscas foram selecionados 36 títulos de obras secundárias, que abordam diretamente o tema, objetivo principal e objetivos secundários desta pesquisa (Capítulo 1). Somam-se 45 títulos secundários no total, dos quais 9 compuseram o acervo para embasamento teórico, contexto histórico e metodologia científica.

Quanto aos textos primários, foram selecionados 40 títulos a partir de citações ou referências bibliográficas em artigos, livros ou nos próprios documentos analisados, mas também em sites oficiais de instituições de governo brasileiro ou instituições não governamentais globais. Incluem legislações, políticas públicas, relatórios, manuais, normas, declarações, agendas, estatísticas, entre outros documentos oficiais publicados por ministérios ou órgãos institucionais governamentais.

Entre obras primárias e secundárias, este trabalho de mestrado se baseou num total de 85 títulos, dos quais 30 receberam análise metodológica documental e bibliográfica. 
A organização destes conteúdos a título de verificar a composição das fontes de pesquisa documental e bibliográfica, ilustrada pela Figura 5, foi feita por meio da categorização dos assuntos e segundo o número de obras.

Figura 5 - Categorias das literaturas

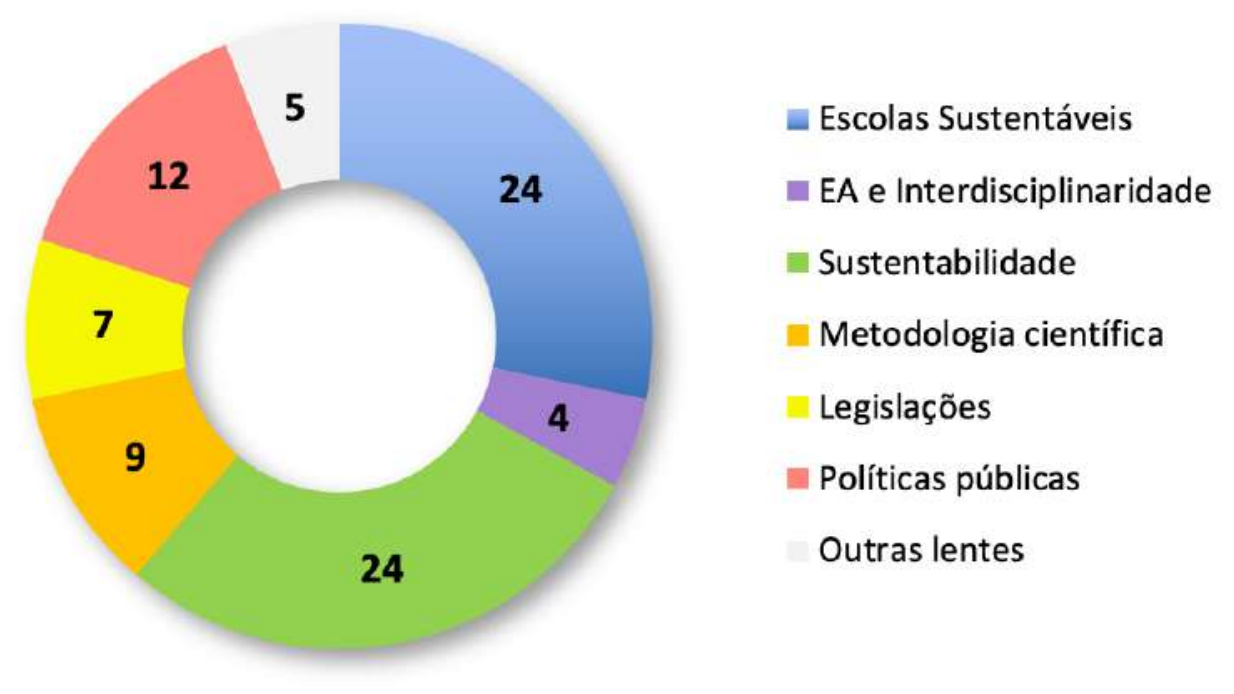

Fonte: Yara Santucci Barreto, 2019

- Escolas Sustentáveis: eco-escolas, green-schools, programas governamentais e políticas públicas educacionais para escolas sustentáveis ao redor do mundo; espaço físico escolar; indicadores de sustentabilidade em escolas; escolas para o futuro.

- EA e Interdisciplinaridade: alfabetização ecológica e ecoletramento; interdisciplinaridade e transdisciplinaridade.

- Sustentabilidade: desenvolvimento sustentável; agendas globais; obras centrais de teoria e reflexão para a transição; indicadores de sustentabilidade.

- Metodologia Científica: análise documental; análise de conteúdo; abordagens qualitativas em pesquisa.

- Legislações: leis federais acerca da EA; resoluções; Constituição Brasileira.

- Políticas Públicas: Programa Nacional Escolas Sustentáveis (PNES); Programa Dinheiro Direto na Escola (PDDE); COM-Vida; Vamos Cuidar do Brasil; Programa Nacional de Educação Ambiental (ProNEA).

- Outras lentes: arquitetura escolar; arquitetura sustentável; conforto; gestão escolar; manutenção de edificações; percepção e apropriação espacial. 
Observou-se que, após a execução da revisão sistemática de literatura, poucos foram os conteúdos encontrados com o objetivo de equalizar os princípios do conceito Escola Sustentável de forma científica e equânime - contemplando os três elos da sustentabilidade havendo favorecimento ora num ou noutro aspecto.

O programa Eco-Schools da Foundation for Environmental Education (FEE) ${ }^{16}$, que nasceu de um modelo europeu e evoluiu para um modelo global de EA e EDS (SHARMA, 2018); livros dedicados à arquitetura escolar sustentável (FORD et al., 2007; GELFAND, 2010); manual de implantação da permacultura em escolas, como o de Legan (2009), Criando Habitats na Escola Sustentável; legislações como a Resolução no 2, de 15 de junho de 2012 do Conselho Nacional de Educação que estabelece as diretrizes curriculares nacionais para a EA; políticas públicas para implementar a EA nas escolas que incluam o espaço físico escolar, como o Programa Nacional Escolas Sustentáveis desenvolvido em 2013 pela Coordenação-Geral de Educação Ambiental CGEA/DPDHUC/SECADI/MEC; questionário de identificação da qualidade dos espaços físicos escolares, como o desenvolvido pela Organização para a Cooperação e Desenvolvimento Econômico (OECD), o School User Survey (OECD, 2018); ou artigos recentes sobre modelos de escolas em periódicos internacionais de educação e sustentabilidade como o CELE - Centre for Effective Learning Environments da OECD; são exemplos claros que demonstram em diversos âmbitos haver um amplo caminho em curso para a construção de uma nova ótica ampliada para a educação básica atual e futura em prol da formação gradual de uma sociedade progressivamente consciente sobre seus atos e comprometida com a vida do e no planeta.

\subsection{CONTEXTO HISTÓRICO}

A percepção que a revisão de literatura trouxe, é a de que há uma multiplicidade de ações e argumentações a favor do conceito Escola Sustentável ao redor do mundo, com propostas e reflexões válidas, embora por vezes parciais conquanto a lógica sistêmica da sustentabilidade. Muitas, possivelmente, alheias entre si. Na busca por artigos científicos, por exemplo, localizei uma gama surpreendente de assuntos que tangem a preocupação, dentro do que talvez seria possível chamar de uma unanimidade diversificada ao conceito, o que me levou a buscar compreender melhor a trajetória que nos trouxe até essa confluência de opiniões.

O foco desta pesquisa concentra-se em investigar o conceito Escola Sustentável - base para a construção do produto que objetiva. Dessa forma, se torna imprescindível o exercício da 
visão abrangente a que todo tema vinculado à sustentabilidade inevitavelmente se submete - o que, neste caso, significa apreender o contexto histórico de onde partiram essas movimentações de transição dos espaços físicos escolares para o conceito Escola Sustentável.

\subsubsection{DESASTRES AMBIENTAIS}

A cultura de desenvolvimento econômico construída a partir da revolução industrial suporta a crença em grandes produtores, grandes indústrias, em grandes lucros, em grandes mercados como forma de atender a grandes populações. As grandes estruturas que nasceram com a revolução industrial e crescimento populacional vêm também gerando desde então grandes impactos e externalidades ambientais. Lélé (1991) já havia concluído que isso tudo reforça a conclusão de que o desenvolvimento sustentável necessita "mudar a qualidade do crescimento". Meadows (1999) reitera e vai além afirmando ser "necessário um crescimento muito mais lento $[\ldots]$, nenhum crescimento ou crescimento negativo."

Desde a década de 60 a sociedade já era alertada por estudiosos sobre o modelo de crescimento socioeconômico insustentável, originado pelo processo de industrialização e suas graves implicações ambientais.

O inseticida de baixo custo DDT (Dicloro-Difenil-Tricloroetano), assim como muitos outros inseticidas - chamados de "biocidas" por Carson (1969), utilizados indiscriminadamente desde 1943 e no pós-guerra, diretamente sobre soldados, ambientes domésticos, bairros inteiros, para combater piolhos, carrapatos e insetos transmissores de doenças, ou por fazendeiros para combater "pestes" agrícolas, decorrentes da simples anulação da biodiversidade pelas monoculturas - contaminaram o solo e a água, eliminaram apiários, comprometendo polinizações, alterando o ecossistema natural da fauna e flora e trazendo altos riscos à saúde pública pelo seu efeito acumulativo no organismo.

O mercúrio lançado por mais de duas décadas desde 1930 na baía de Minamata, Japão, pela empresa química Chisso, contaminou peixes e frutos do mar, base alimentar na região, causando muitas mortes e intoxicações graves com sequelas neurológicas até hoje observadas. ${ }^{17}$

Catástrofes como essas, provocadas no período pós Segunda Guerra Mundial por despejo de produtos tóxicos no meio ambiente, ainda causavam surpresa quando começariam então a nascer as primeiras sementes plantadas pela EA. Importantes publicações como "Fundaments of Ecology", de Eugene P. Odum, ornitólogo norte-americano, lançada em 1953,

$17 \mathrm{https} / /$ acervo.oglobo.globo.com/fatos-historicos/desastre-de-minamata-crime-ecologico-que-deixou-marcas-por-decadasno-japao-10102255 
ou "Primavera Silenciosa", de Rachel Carson, escritora, cientista e ecologista norte-americana, lançada em 1962, ambas reeditadas sucessivas vezes, ou ainda “Antes que a Natureza Morra”, do francês Jean Dorst, em 1965, catalisaria o movimento de construção da EA. Desde então se desdobraram encontros, conselhos, congressos, conferências, agendas, fóruns, cúpulas, workshops e toda gama de eventos, que vêm debatendo, estudando, analisando, divulgando o cenário ambiental mundial com uma frequência cada vez maior. (BRASIL, 1998).

Novos desastres de grandes proporções na década de 80 , porém, como o de vazamento mortal de isocianato de metila a partir da explosão de um tanque da empresa Union Carbide em Bhopal, na Índia ${ }^{18}$, ou a explosão de reator na Usina Nuclear de Chernobyl, na antiga União Soviética ${ }^{19}$, com suas dezenas de milhares de mortes, reforçaram ainda mais a comoção geral e a preocupação da sociedade perante tais cenários e mostraram que muito mais seria necessário para a mudança de condutas se efetivar.

O conceito de sustentabilidade vai surgindo da reação de preocupação e insegurança da sociedade causada pelos desastres ambientais decorrentes da negligência - ou ausência de uma EA de base que pudesse assegurar uma visão abrangente, que desse condições ao menos mínimas de sustentabilidade aos avanços do crescimento econômico pretendido pela mesma sociedade e de segurança à saúde (informação verbal) ${ }^{20}$.

\subsubsection{LINHA HISTÓRICA INSTITUCIONAL DA EDUCAÇÃO AMBIENTAL E SUSTENTABILIDADE}

Em 1942, durante a Segunda Guerra Mundial, por iniciativa de Roosevelt (EUA) e Churchill (RU), 26 países da força aliada se uniram em prol de oito princípios comuns de esperança por um "futuro melhor para o mundo", paz, liberdade, soberania, prosperidade - a Declaração das Nações Unidas. Até o final da guerra, se tornariam 50 países membros, quando em 1945 se formalizaria a organização entre as Nações Unidas, a ONU²1, que hoje reúne 193 países membros em torno das mesmas causas e ao longo de sua história vem se dedicando à construção dos caminhos de tais termos. Mas os primeiros registros da utilização do termo “Educação Ambiental” datam de 1948, quando do encontro inaugural da União Internacional para a Conservação da Natureza (UICN) ${ }^{22}$, em Fontainebleau, França - uma união de membros

$18 \mathrm{https} / /$ acervo.oglobo.globo.com/incoming/a-tragedia-de-bhopal-24102018

19 https://acervo.oglobo.globo.com/fotogalerias/o-acidente-nuclear-de-chernobyl-9948617

20 Mesa Redonda "Desenvolvimento sustentável e Sustentabilidade: visões e desafios" por Prof ${ }^{\circ} \operatorname{Dr}^{\circ}$ Valdir Fernandes

(UFTPR) em 9 de setembro de 2020 na disciplina Indicadores de Sustentabilidade para o Programa de Pós-Graduação em

Rede Nacional para Ensino das Ciências Ambientais (PROFCIAMB).

$21 \mathrm{https} / / / \mathrm{www}$.un.org/en/sections/history/history-united-nations/index.html

$22 \mathrm{https} / / / \mathrm{www}$. iucn.org/ 
composta exclusivamente por organizações governamentais e da sociedade civil, que até hoje proporciona às organizações públicas, privadas e não governamentais o conhecimento e as ferramentas que permitam o progresso humano, o desenvolvimento econômico e a conservação da natureza de forma conjunta.

Em 1968, um cientista e um industrial concernentes com o futuro da humanidade no planeta fundaram o Clube de Roma, que ainda também permanece reunindo economistas, líderes empresariais, ex-políticos e pesquisadores em torno de soluções abrangentes para as atuais questões complexas do nosso mundo ${ }^{23}$.

Em 1972, a Conferência da ONU sobre o Meio Ambiente Humano, em Estocolmo, Suécia, reúne 113 países e "atribui a inserção da temática da Educação Ambiental na agenda internacional" com 26 princípios construídos ao redor do tema. A conferência de Estocolmo, como ficou conhecida, trouxe também pela primeira vez o termo "desenvolvimento sustentável" em seu relatório intitulado Limites do Crescimento, encomendado pelo Clube de Roma ao Massachussets Institute of Technology (MIT) e coordenado por Donella Meadows. O padrão produção/consumo exagerado junto com o veloz crescimento populacional e as consequentes depressão dos recursos não renováveis e deterioração do meio ambiente já comprometiam a capacidade de regeneração das reservas naturais para além de 100 anos, caso mantivessem aquele mesmo ritmo. Traria consequências desastrosas e demandaria limites, o que retumbou sobre a sociedade mundial. Em pleno processo de industrialização na ditadura militar, o Brasil rejeitou o documento. Entretanto, sequencialmente, em 1973, o governo militar brasileiro institucionaliza a EA em âmbito federal com a criação da Secretaria Especial do Meio Ambiente (SEMA), vinculada à Presidência da República. (ONU, 1972; BRASIL, 2007a; MEADOWS, 1972).

Em 1975, lança-se em Belgrado, na então Iugoslávia, o Programa Internacional de Educação Ambiental, no qual são definidos oito "Princípios Orientadores de Programas de Educação Ambiental", sendo contemplado pertinentemente logo no primeiro, o ambiente antrópico: “A educação ambiental deve considerar o meio ambiente em sua totalidade - natural e antrópico, ecológico, político, econômico, tecnológico, social, legislativo, cultural e estético". (UNESCO-UNEP, 1976, p. 2).

Em 1977, na Conferência Intergovernamental sobre Educação Ambiental em Tibilisi, na Georgia (ex-União Soviética), organizada "a partir da parceria entre a UNESCO e o então 
recente Programa de Meio Ambiente da ONU (PNUMA)" (BRASIL, 2007a, p. 12), 41 recomendações foram elencadas sobre EA em sua Declaração, demonstrando logo na primeira delas as preocupações sobre as quais a EA traria luz:
Um dos objetivos fundamentais da educação ambiental é conseguir que os indivíduos e as coletividades compreendam a natureza complexa do meio ambiente natural e do meio criado pelo homem, resultante da interação de seus aspectos biológicos, físicos, sociais, econômicos e culturais, e que adquiram conhecimentos, valores, comportamentos e habilidades práticas para participarem, com responsabilidade e eficácia, da prevenção e solução dos problemas ambientais e da gestão da qualidade do meio ambiente;
[...] cabe à educação ambiental dispensar os conhecimentos necessários para se interpretar os complexos fenômenos que configuram o meio ambiente e fomentar os valores éticos, econômicos e estéticos que constituem a base da autodisciplina, favorecendo o desenvolvimento de comportamentos compatíveis com a preservação e a melhoria do meio [...]. (UNESCO; IBAMA, 1997).

As estratégias traçadas para esse evento, que partiram desde as premissas de Estocolmo, foram consideradas "alicerces para a o desenvolvimento da EA em todos os níveis, dentro e fora do sistema escolar" o que é comprovado por terem sido corroboradas em novos eventos globais futuros. (BRASIL, 1998, p. 30-34).

Em 1981, a Lei No 6938 estabelece a Política Nacional de Meio Ambiente (PNMA), que "estabeleceu, no âmbito legislativo, a necessidade de inclusão da Educação Ambiental em todos os níveis de ensino, incluindo a educação da comunidade, objetivando capacitá-la para a participação ativa na defesa do meio ambiente”. (BRASIL, 2007a, p.13).

Em 1987, 94 países debatem avanços e dificuldades sobre EA em dez anos de Tibilisi na Conferência Internacional sobre Educação e Formação Ambiental em Moscou e propõem a "Estratégia Internacional de Ação em Matéria de Educação e Formação Ambiental para o Decênio de 90". Pouco antes no mesmo ano, o antigo Conselho Federal de Educação aprova o Parecer 226/87, que enfatiza a urgência da introdução da EA "a partir da escola, numa abordagem interdisciplinar, levando à população posicionamento em relação a fenômenos ou circunstâncias do ambiente". O documento sugeriu também a criação de Centros de Educação Ambiental (CEA) nos Estados, para irradiar a EA no Brasil. (BRASIL, 1998, p. 33-43).

Com a retomada da democracia no Brasil, a Constituição Federal de 1988 vem preconizar o meio ambiente em praticamente todas suas seções, além de seu capítulo VI, Do Meio Ambiente, exclusivo ao tema, onde a referência à EA está localizada suscintamente no inciso VI do parágrafo $1^{\text {o: }}$ "Promover a educação ambiental em todos os níveis de ensino e a conscientização pública para a preservação do meio ambiente.” (BRASIL, 1988). 
A inclusão do tema na Constituição brasileira e a criação subsequente, em fevereiro de 1989, do Instituto Brasileiro do Meio Ambiente e dos Recursos Naturais Renováveis (IBAMA), possivelmente foram influenciadas pela forte repercussão do Relatório de Brundtland no ano de 1987, intitulado Nosso Futuro Comum, elaborado pela Comissão Mundial sobre o Meio Ambiente e o Desenvolvimento, chefiada pela então primeira-ministra da Noruega, Gro Harlen Brundtland. O documento insere um novo paradigma de desenvolvimento com a visão da sustentabilidade sob todos os aspectos - essencialmente econômicos, sociais e ambientais como forma de suprir as necessidades da geração presente sem afetar a possibilidade das gerações futuras de suprir as suas. Embora tenha publicado sobre o mesmo ritmo defasado entre consumo e recarga dos estoques naturais de recursos que o relatório de 1972, dá uma tônica menos pessimista, adotando o caminho do meio, acreditando numa conciliação entre crescimento econômico e preservação ambiental. Ou seja, conclui-se que a sociedade e seus representantes não estariam dispostos a abrir mão de suas necessidades e aspirações, mas buscar meios de calibrar os mecanismos exploratórios para um padrão menos nocivo em que pudesse localizar o ponto de equilíbrio ecológico, prevendo a revisão de valores, do consumismo e dos modelos de negócios, o que modificou o modelo de desenvolvimento. (KATES; PARRIS; LEISEROWITZ, 2005). Consiste em sair do modelo "crescer a qualquer custo" para o da solidariedade às gerações futuras e à sobrevivência da própria espécie humana. Adota-se então instrumentalizar e organizar as instituições e governos, dentro dessas novas condicionantes, por meio de uma manutenção de convenções internacionais com periodicidades em média de 5 a 10 anos.

Em 1992, a Agenda 21, por exemplo, foi o resultado da Conferência da ONU, conhecida por Rio 92, que reuniu 178 países ao redor da construção de propostas e medidas para o planejamento do desenvolvimento de forma sustentável, organizando e elencando não apenas parâmetros sociais, ambientais, econômicos e suas instituições, mas também meios de convergir para a implementação internacional desses preceitos, que conformou num programa de ações distribuídas em 40 capítulos. O seu capítulo 40 trouxe especificamente a contribuição aos países e organizações de buscarem bases sólidas de dados próprios como meio seguro de identificarem suas demandas com maior precisão e objetividade. (UNSD, 1992, p. 346-351). A nova ótica "pensar globalmente e agir localmente" ecoada a partir da Rio 92, catalizaria ao redor do mundo o desenvolvimento de programas dedicados a incorporar a sustentabilidade na educação. 
Estudos afirmam que nesse momento a EA passa a ser substituída pela EDS, que se baseia nos mesmos princípios, mas "sua preocupação central é desviar a educação para o desenvolvimento sustentável, em vez de apenas para a sustentabilidade ambiental." (HARB; ELHAGGAR; SEWILAM, 2019). De fato, programas sistematicamente buscam se alinhar aos três pilares - social, ambiental e econômico - do desenvolvimento sustentável, tais como: Enviroschools (Nova Zelândia, 1993), Eco-Schools (Dinamarca, Alemanha, Grécia e Reino Unido, 1994), ECOLOG (Austria, 1996), Green School (China, 1996), Australian Sustainable Schools Initiative - AuSSI (1997), EcoSchools (Canadá, 1999), Sustainable Schools (Australia 2002), entre outros; todos vigentes e ativos ao redor do globo com procedimentos que embora apresentem similaridades, possuem variáveis claras entre si, como por exemplo os modelos Enviroschools, Eco-Shools e Sustainable Schools, apresentados na Figura 6. (GOUGH; GOUGH, 2019).

Figura 6 - Diversidade entre programas de educação para a sustentabilidade em escolas

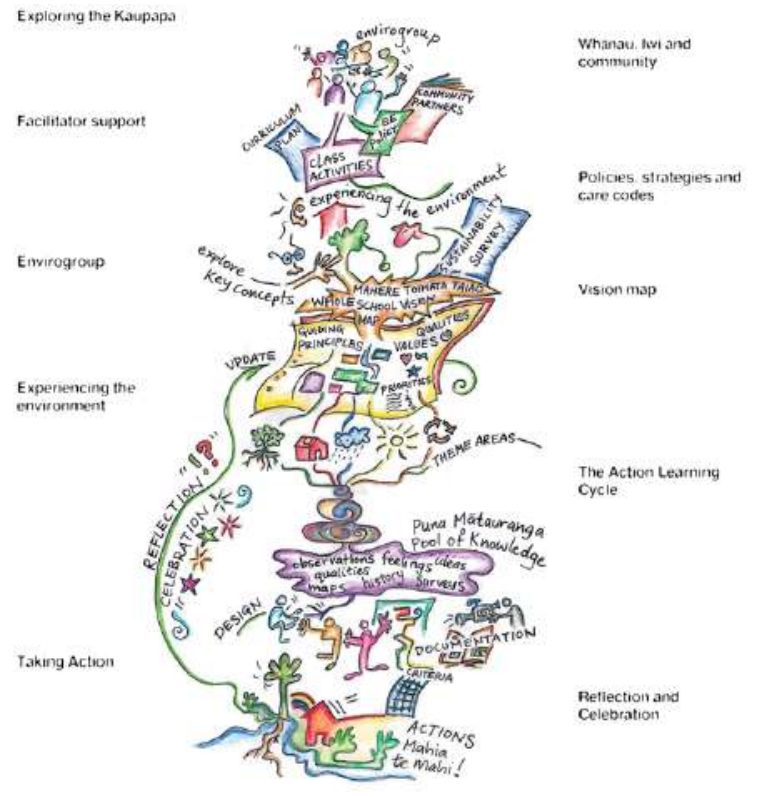

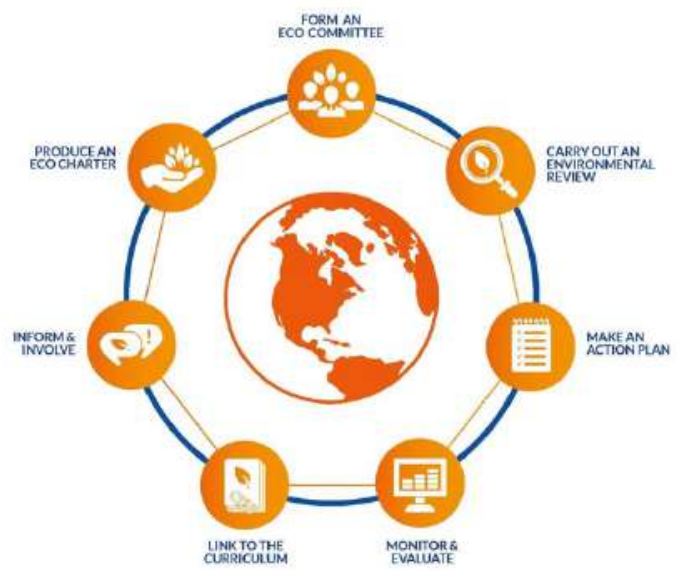

Eco-Schools Seven Step

The Enviroschools Programme

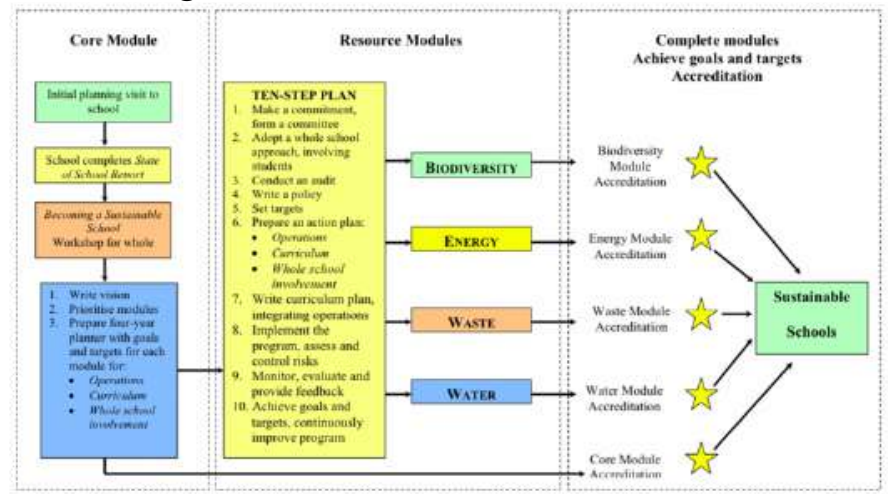

Sustainable Schools Process

Fontes: https://enviroschools.org.nz/about-us/; GOUGH; GOUGH, 2019. 
Nesse mesmo impulso, surgem paralelamente sistemas de classificação de edifícios verdes, como o Building Research Establishment Environmental Assessment Method (BREAM), da Building Research Establishment (BRE) e o Leadership in Energy and Environmental Design (LEED), da U.S. Green Building Council (USGBC), ambos muito presentes globalmente, além de diversos outros que atuam localmente em seus respectivos países, em certificações visando proporcionar de reduções de consumo de recursos naturais à benefícios sociais e econômicos enquanto mitigam os impactos ambientais do ambiente construído (Figura 7).

Figura 7 - Certificações ambientais de edificações

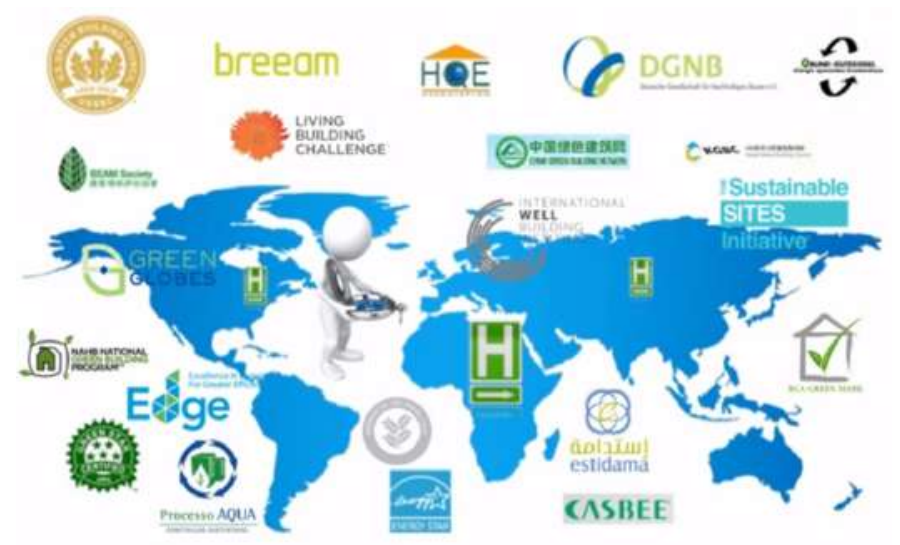

Fonte: https://ecobuildingforum.com.br/as-5-certificacoes-ambientais-mais-conhecidas-no-brasil/

Em 1995, a Comissão de Desenvolvimento Sustentável (CSD) da ONU, desdobramento relevante da proposta desse mesmo capítulo, elaborou inicialmente 134 indicadores para o desenvolvimento sustentável (ISD) balizados pela Agenda 21 e os testou até 1999 em 22 países voluntários. Os resultados levaram a uma revisão que os sintetizou em 58 indicadores. (DESA, 2007, p. 5-6).

Em 1997, a Conferência Meio Ambiente e Sociedade: Educação e Consciência Pública para a Sustentabilidade organizada pela UNESCO reuniu em Thessaloniki, Grécia, 90 países que elaboraram declaração reafirmando preceitos oriundos da Agenda 21 e também de Tibilisi.

Enfatizando a virada do milênio, em setembro de 2000, a Assembleia Geral da ONU reuniu 191 governos para reunir as diretrizes que vinham sendo discutidas quanto aos rumos da globalização e seus resultados desiguais entre as nações. Para tanto, a "Cúpula do Milênio", como foi nomeada, gerou a "Declaração do Milênio", onde 8 objetivos foram traçados para os 15 anos subsequentes, prevendo ações em prol da igualdade e inclusão social, boa governança e proteção do meio-ambiente. Foram adotados indicadores estatísticos acerca da população abaixo da linha da pobreza, subnutrição, sub-empregos, escolaridade infantil, paridade 
educacional, de trabalho e de participação entre gêneros, mortalidade infantil, vacinação, mortalidade e assistência no pré-natal/parto/pós-parto, faixa-etária de engravidamento, prevenção e mortes por HIV, malária, tuberculose, emissões de poluentes, consumo, limites biológicos, índices de extinção de espécies, áreas de preservação, acesso à água e saneamento, exportações e tarifas, assistência financeira, dívida externa, acesso à internet e aquisição de linhas de telefonia celular. Os resultados dos esforços globais envolvidos para tais equalizações foram significativos e positivos, incentivando a uma atitude continuada de tais ações. (IPEA, 2014; UNDP, 2015).

Em 2000, é lançada a Carta da Terra, documento internacional escrito desde os preâmbulos da Rio-92 num processo participativo sem precedentes, "endossada por 14.000 indivíduos e organizações em todo o mundo" (KATES; PARRIS; LEISEROWITZ, 2005). No mesmo ano, as contribuições da Declaração do Milênio, que consolidam a responsabilidade conjunta das nações no levantamento e disponibilização dos dados, levaram a CSD à uma nova revisão dos ISD, até que em 2007 foram totalizados 50 indicadores essenciais de desenvolvimento sustentável, que se desdobram à 96, permitindo gerenciamentos segundo as avaliações de cada país (DESA, 2007, p. 9). O Brasil, por sua vez, pelo Instituto Brasileiro de Geografia e Estatística (IBGE), adotou os ISD da CSD como referência para a elaboração de seu próprio roteiro, que se estendeu de 2002 até 2015. Nessa experiência brasileira em aplicar tais indicadores foram necessárias diversas adaptações à nossa realidade e, ainda que muitos parâmetros não possam ter encontrado total encaixe em nosso cenário, certamente ampliou as reflexões abrangentes e pôde haver um aprimoramento do sistema das coletas de dados brasileira. (BOLLINGER; SCANDAR, 2004; IBGE, 2015).

Em 2002, na Conferência de Johannesburgo, a UNESCO estabelece a Década da Educação para o Desenvolvimento Sustentável entre 2005 e 2014, quando os esforços nessa direção se tornam uma agenda disseminada em agências governamentais e privadas. (MAHAT, et al., 2016; HARB; ELHAGGAR; SEWILAM, 2019; MOORE, et al, 2019; FRANQUESASOLER; SANDOVAL-RIVERA, 2019).

Em 2015 nova iniciativa da ONU expandiu os 8 Objetivos do Milênio (ODM) para 17 Objetivos de Desenvolvimento Sustentável (ODS) ${ }^{24}$, com 169 metas escritas a partir do compromisso com diversos documentos anteriores, novamente somando e avolumando expertises e experiências em direção a um mundo mais justo, equânime e resiliente. Na atual 
missão pós-2015 de força-tarefa da ONU, a medição das evoluções rumo aos objetivos previstos para novos 15 anos vem sendo feita em periodicidade anual. Os ODS destacam questões antes inseridas entre metas dos objetivos, promovendo-as a uma atenção focal. A Agenda 2030, como foi chamada, amplia substancialmente a visão abrangente dentro de cada objetivo, assistindo uma gama real de problemas a serem enfrentados e vencidos. Para tanto, além dos indicadores já provenientes dos documentos anteriores, incluem novos, ainda mais inclusivos em diversos aspectos sociais, para avaliações de temas como bem-estar, vida saudável, preocupação com adictos a tóxicos e álcool, cultura de paz, formação de professores, reciclagem, turismo, comércio, indústria, pesquisa científica, urbanismo, patrimônio cultural, consumo, ecossistemas, ética, transparência. Conformam ações que atendem cenários de forma sistêmica, mas por meio de um modelo simplificado e didático, acessível a quaisquer esferas - empresas, governo, instituições, negócios ou famílias. (IPEA, 2014; ONU, 2015; PNUD, 2015).

Aos poucos os esforços globais vão se somando e ganhando volume. Novos custos envolvidos nos incrementos e exercícios institucionais para tais levantamentos e principalmente nas ações corretivas podem ser encarados como investimentos para o futuro. Assim como os IDS brasileiros, a Agenda 21 brasileira, concluída somente em 2001, veio assinalar o início do comprometimento do país nessa associação mundial em prol do desenvolvimento sustentável. (BOLLINGER; SCANDAR, 2007; IBGE, 2015).

$\mathrm{Na}$ linha histórica brasileira após a Rio 92, vemos em 1994 o nascimento do Programa Nacional de Educação Ambiental, o ProNEA, dois anos após a Agenda 21, resultante da parceria entre quatro ministérios - MEC, MMA, Cultura, Ciência e Tecnologia. Sua criação certamente foi também impulsionada pelos princípios estabelecidos pela sociedade civil no Tratado de Educação Ambiental para Sociedades Sustentáveis e Responsabilidade Global no Fórum Global durante a Rio 92, como o pensamento crítico, coletivo e solidário, de interdisciplinaridade, de multiplicidade e diversidade, também um plano de ação para educadores ambientais e ainda processos participativos voltados para a recuperação, conservação e melhoria do meio ambiente e da qualidade de vida. (BRASIL, 2007a, p.103107). Dentre as perspectivas do ProNEA, teria na "boa gestão ambiental" e no ensino formal da escola instrumentos de "aprofundamento e sistematização da EA". (BRASIL, 1998, p. 129).

A partir do ProNEA, iniciaram-se no Brasil movimentos como: a $1^{\text {a }}$ Conferência Nacional de Educação Ambiental (CNEA) em 1997, cuja Declaração de Brasília para a Educação Ambiental, redigida a partir de seus relatórios regionais, reuniu um complexo de críticas e demandas em aberto quanto à implantação da EA em âmbitos nacional, estadual e 
municipal e foi levada à Thessaloniki no mesmo ano para representar oficialmente a EA brasileira (BRASIL, 1998, p. 63-70); a Política Nacional de Educação Ambiental (PNEA) pela Lei 9.795 em 1999; as cinco Conferências Nacionais Infantojuvenis pelo Meio Ambiente (CNIJMA), que ocorreram entre 2003 a 2018. O MEC, que desde 1995 vinha elaborando os Parâmetros Curriculares Nacionais (PCN), em 1997 define as áreas de conhecimento obrigatórias, mas também cinco temas transversais, que incluem Meio Ambiente. (p. 61).

Em 2004, o MEC cria a Secretaria de Educação Continuada, Alfabetização e Diversidade (SECADI), quando a EA ganha ainda maior visibilidade por se tornar transversal, do MMA ao MEC. Em resposta às CNIJMA I e II, o Programa Vamos Cuidar do Brasil, que se originou em 2004, concluiria em 2007 a implantação da política pública Comissões de Meio Ambiente e Qualidade de Vida nas Escolas (COM-Vida). Em 2012, seriam definidas as Diretrizes Curriculares Nacionais para a Educação Ambiental - Resolução $n^{\circ} 2$ do Conselho Nacional de Educação (CNE) - e então criado, em 2013, o Programa Nacional Escolas Sustentáveis (PNES), com seus três eixos - currículo, gestão e espaço físico (Figura 8) - para compor mais uma vertente de atuação da EA, favorecendo a internalização das Diretrizes Curriculares Nacionais para a Educação Ambiental, amparado pelo Programa Dinheiro Direto na Escola-Escolas Sustentáveis (PDDE-ES), versão do PDDE criada para suplementar financeiramente escolas públicas de ensino básico das redes estaduais e municipais frente à manutenções e melhorias de infraestrutura de ordem física e pedagógica, atendidas “necessariamente" pela COM-Vida e suas premissas: temática socioambiental inserida no PPP, participação social e autogestão escolar. Infelizmente, como já foi contextualizado no início desta pesquisa, o PNES sucumbiu em 2016 e com ele, a versão PDDE-ES. (BRASIL, 2012a; 2012b; 2012c; 2013b; 2014a).

Figura 8 - Gráfico das Escolas Sustentáveis - PNES

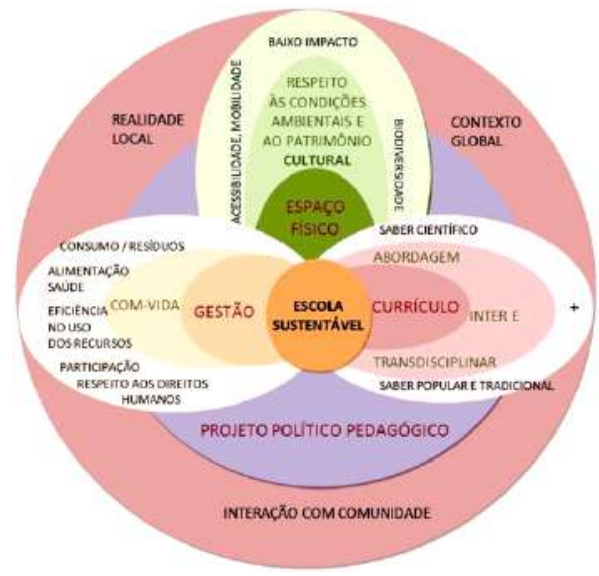

Fonte: BRASIL, 2013b, p. 4. 
Reunindo os eventos internacionais e nacionais até aqui mencionados em uma linha do tempo, teríamos:

Tabela 12 - Linha histórica institucional da Educação Ambiental e Sustentabilidade no Brasil a partir de movimentos internacionais

\begin{tabular}{|c|c|}
\hline Ano & Título do Evento \\
\hline 1942 & Declaração das Nações Unidas - Washington, EUA \\
\hline 1945 & Organização das Nações Unidas - ONU - São Francisco, EUA \\
\hline 1948 & $\begin{array}{l}\text { União Internacional para a Conservação da Natureza (UINC) - Fontainebleau, } \\
\text { França }\end{array}$ \\
\hline 1968 & Clube de Roma, Itália \\
\hline 1972 & Relatório Limites do Crescimento e Conferência de Estocolmo, Suécia \\
\hline 1973 & Secretaria Especial do Meio Ambiente (SEMA) \\
\hline 1975 & Programa Internacional de Educação Ambiental - Belgrado, Iugoslávia \\
\hline 1977 & $\begin{array}{l}\text { Conferência Intergovernamental sobre Educação Ambiental, UNESCO + } \\
\text { PNUMA ONU - Tibilisi, Georgia }\end{array}$ \\
\hline 1981 & Lei No 6938 - Política Nacional de Meio Ambiente (PNMA) \\
\hline 1985 & Ministério do Desenvolvimento Urbano e Meio Ambiente \\
\hline 1987 & Relatório de Brundtland - Nosso Futuro Comum \\
\hline 1987 & Conferência Internacional sobre Educação e Formação Ambiental, Moscou \\
\hline 1987 & Parecer 226/87 - Conselho Federal de Educação \\
\hline 1988 & Constituição Federal Brasileira \\
\hline 1989 & $\begin{array}{l}\text { Instituto Brasileiro do Meio Ambiente e dos Recursos Naturais Renováveis } \\
\text { (IBAMA) }\end{array}$ \\
\hline 1992 & $\begin{array}{l}\text { RIO } 92 \text { (ou ECO 92) Conferência das Nações Unidas sobre o Meio Ambiente e } \\
\text { o Desenvolvimento: Agenda } 21 \text { e Tratado de Educação Ambiental para } \\
\text { Sociedades Sustentáveis e Responsabilidade Global - Fórum Global }\end{array}$ \\
\hline 1993 & Início dos programas de sustentabilidade na educação ao redor do mundo \\
\hline
\end{tabular}




\begin{tabular}{|c|c|}
\hline & Primeiros sistemas de classificação de edifícios verdes \\
\hline 1994 & Programa Nacional de Educação Ambiental (ProNEA) \\
\hline 1995 & $\begin{array}{l}\text { Indicadores para o desenvolvimento sustentável pela Comissão de } \\
\text { Desenvolvimento Sustentável (CSD) - ONU }\end{array}$ \\
\hline \multirow{3}{*}{1997} & $\begin{array}{l}1^{\text {a }} \text { Conferência Nacional de Educação Ambiental (CNEA) - "Declaração de } \\
\text { Brasília para a EA" }\end{array}$ \\
\hline & Parâmetros Curriculares Nacionais (PCN) \\
\hline & $\begin{array}{l}\text { Conferência Internacional sobre Meio Ambiente e Sociedade: Educação e } \\
\text { Consciência Pública para a Sustentabilidade - Thessaloniki, Grécia }\end{array}$ \\
\hline \multirow{2}{*}{1999} & Lei 9.795 - Política Nacional de Educação Ambiental (PNEA) \\
\hline & Revisão I dos Indicadores para o desenvolvimento sustentável (ISD) - CSD \\
\hline \multirow{3}{*}{2000} & Carta da Terra \\
\hline & $\begin{array}{l}\text { Declaração do Milênio - } 8 \text { Objetivos de Desenvolvimento do Milênio (ODM) - } \\
\text { ONU }\end{array}$ \\
\hline & Agenda 21 Brasileira - Bases para Discussão \\
\hline 2001 & Agenda 21 Brasileira \\
\hline 2002 & Conferência de Johannesburgo, África do Sul \\
\hline 2003 & Conferência Nacional Infantojuvenil pelo Meio Ambiente (CNIJMA I) \\
\hline \multirow{2}{*}{2004} & Secretaria de Educação Continuada, Alfabetização e Diversidade (SECADI) \\
\hline & Programa Vamos Cuidar do Brasil \\
\hline $2005-6$ & Conferência Nacional Infantojuvenil pelo Meio Ambiente (CNIJMA II) \\
\hline \multirow{2}{*}{2007} & Revisão II dos Indicadores para o desenvolvimento sustentável (ISD) - CSD \\
\hline & Comissões de Meio Ambiente e Qualidade de Vida nas Escolas (COM-Vida) \\
\hline $2008-9$ & Conferência Nacional Infantojuvenil pelo Meio Ambiente (CNIJMA III) \\
\hline 2010 & Conferência Internacional Infantojuvenil (CONFINT) \\
\hline
\end{tabular}


2012

Diretrizes Curriculares Nacionais para a Educação Ambiental pelo CNE Resolução $n^{\circ} 2$

2012-13 Conferência Nacional Infantojuvenil pelo Meio Ambiente (CNIJMA IV)

2013 Programa Nacional Escolas Sustentáveis (PNES)

2015 Agenda 2030 - 17 Objetivos de Desenvolvimento Sustentável (ODS) - ONU

2015 Indicadores brasileiros para o desenvolvimento sustentável (IDS) - IBGE

2017-18 Conferência Nacional Infantojuvenil pelo Meio Ambiente (CNIJMA V)

Fonte: Yara Santucci Barreto, 2020

Políticas públicas e programas têm o poder de alavancar movimentos de maior porte e promover avanços reais, quando de forma continuada. Na última edição do ProNEA, de 2018, permanecem as COM-Vida e a referência à todas as leis e resoluções já mencionadas e diversos outros marcos oficiais, mas exclui o PNES, que foi descontinuado. (BRASIL, 2007ª; 2010; 2018).

A evolução histórica da EA no Brasil, no entanto, vem demonstrar a sua vocação e aspiração entre os atores públicos e sociais no cenário escolar brasileiro, confirmada em depoimentos e pesquisas, como por exemplo a realizada em doze escolas públicas paulistas, onde destacam que para os atores entrevistados, "questões vinculadas à sustentabilidade eram consideradas 'vitais', pois mesmo com o repasse financeiro pendente, conseguiam trabalhar nessa direção", referindo-se a um atraso de dois à oito anos à essas instâncias escolares, contempladas pelo PNES, via PDDE. (BOGADO; FREITAS, 2017).

Essa breve linha histórica não se encerra nos eventos elencados, tampouco pretende ir além de referências históricas orientadoras. Porém, visa elucidar sobre a evolução dos conceitos de EA e da Sustentabilidade como referencial ético e catalizador para o ensino das ciências ambientais, que este trabalho e o programa ao qual se submete intencionam. Dentro desse arcabouço histórico, um esforço profundo e global é claramente percebido - o que imprimiu consciência, responsabilidade e comprometimento com tais evoluções na construção desta pesquisa e produto. Pelas mesmas razões, não caberia serem tais eventos incorporados ao currículo escolar? 


\subsection{EMBASAMENTO TEÓRICO}

À frente de seu tempo, Fuller (1969), exercia continuamente o pensar abrangente. Arquiteto, educador, cientista, matemático, poeta, economista, entre diversas outras formações, foi o inventor da cúpula geodésica, com a qual representou o princípio da sinergia, sua maior crença. "A sinergia é da essência” (p. 60), dizia.

Buscou polinizar a ideia de que "a especialização impede o pensamento global" em visitas à mais de 300 universidades e institutos ao redor do mundo. Defendia nos libertarmos da "especialização intelectual", que "não passa na realidade de uma forma requintada de escravatura", mas resgatarmos a nossa "globalidade inata". (FULLER, 1969, passim).

As especializações em todas as áreas do conhecimento diminuíram o amplo saber, embora creiam ser o contrário, dada a profundidade cada vez maior em limites cada vez mais restritos. Para Santos (1988, p. 9), “o conhecimento é tanto mais rigoroso quanto mais restrito é o objeto sobre que incide" e nos aponta as consequências disso:

Sendo um conhecimento disciplinar, tende a ser um conhecimento disciplinado, isto
é, segrega uma organização do saber orientada para policiar as fronteiras entre as
disciplinas e reprimir os que as quiserem transpor. É hoje reconhecido que a
excessiva parcelização e disciplinarização do saber científico faz do cientista um
ignorante especializado e que isso acarreta efeitos negativos. (SANTOS, 1988, p. 9).

A ciência moderna tenta recobrar o generalismo para corrigir a limitação da especialização, porém, tornando-o viciosamente em nova especialidade, pois "criam-se novas disciplinas para resolver os problemas produzidos pelas antigas e por essa via reproduz-se o mesmo modelo de cientificidade" (p. 10).

Os “Teaching Green Buildings (TGB)" (COLE, 2014), por exemplo, são projetados "para abordar as dimensões técnicas e socioculturais" de forma abrangente e também "representam uma solução atraente para as ameaças globais substanciais da mudança climática e da escassez de recursos". Têm "muito potencial" educativo, tanto para "integrar questões ambientais construídas [...] na educação formal e, particularmente, nas áreas de ciência, tecnologia, engenharia e matemática (STEM)", como para "transmitir uma ética geral de sustentabilidade aos ocupantes e oferecer uma variedade de oportunidades de aprendizagem de livre escolha para temas de sustentabilidade de forma ampla", na educação informal. No entanto, pesquisas qualitativas e quantitativas recentes vêm procurando encontrar nos edifícios verdes, sejam escolares ou outros, uma comprovação de que por si só geram em seus usuários conhecimento ou engajamento em sustentabilidade. Os TGBs trazem essencialmente uma abordagem de soluções passivas, porém isso não os torna exatamente uma ferramenta de 
comunicação, capaz de gerar conhecimento e atitudes em prol da sustentabilidade em seus usuários pela simples permanência em seus domínios, como estudos de caso demonstram. Podem "gerar consciência" num primeiro momento, pelo impacto que algumas soluções mais atraentes geram ${ }^{25}$, como paineis fotovoltaicos ou bicicletário, por exemplo, "mas não o aprofundamento do saber" em sustentabilidade em todo o seu contexto abrangente, físico, social e ecológico. Embora não haja uma teoria que comprove a conexão de um edifício de soluções sustentáveis com o comprometimento ambiental no comportamento de seus usuários, estudos demonstram que os edifícios verdes "podem desempenhar um papel na mudança de comportamento" de seus usuários, uma vez estes se tornem cientes de suas propriedades e benefícios, o que demanda comunicação e informação de conhecimentos multidisciplinares por parcerias que tragam "forças socioculturais de apoio". O estudo dos TGBs, acima de tudo, "é uma busca interdisciplinar na intersecção da arquitetura e da educação ambiental”, e essa parceria pode dar voz aos edifícios verdes perante seus usuários e ampliar resultados em conhecimento e engajamento (COLE, 2020, passim):

A capacidade de identificar elementos de construção verdes genéricos e de conectar esses elementos a outros sistemas sociais e ecológicos requer uma ampla rede mental de conhecimentos em sustentabilidade que pode ser transportada para vários ambientes. Assim, em vez de saber precisamente como operar recursos e se comportar em um único contexto da construção verde, um ocupante de edifício com GBK factual e conceitual ${ }^{26}$ pode aplicar mais facilmente esse conhecimento em uma variedade de configurações. (COLE, 2020, p. 1051).

Para atender essa ampla gama de conhecimentos, a multi ou interdisciplinaridade ${ }^{27}$ podem se aproximar mais de um bom resultado, quando em sinergia. Uma educação que ensina o pensar abrangente desenvolve habilidades diversificadas e integradas:

O modelo educacional antigo, do aprendizado passivo dos fatos e da repetição descontextualizada não mais é suficiente. No futuro, a necessidade de resolver problemas complexos exigirá que todos tenham habilidades fundamentais, tais como leitura, escrita e cálculo, habilidades avançadas na resolução de problemas, trabalho em equipe, pesquisa aplicada, gerenciamento de tempo, síntese de informação e saber tecnológico. (LEGAN, 2007, p. 12).

Nada seria mais profícuo como cada indivíduo de uma sociedade ter os seus olhares ampliados e uma compreensão do sistema todo. As intersecções entre esses olhares podem ser complementares e ainda mais benéficas. A EA vem propor ir além dos limites da escola e do

\footnotetext{
25 Como vimos no relato de experiência, algumas soluções de alta visibilidade chamam atenção dos usuários e outras de média ou baixa visibilidade passam despercebidas.

26 Green Building Knowledge (GBK) é um termo abrangente adotado que se refere aos conhecimentos adquiridos a partir do conhecimento sobre recursos de sustentabilidade aplicados no edifício. Factual, segundo a autora, seriam sobre os elementos de construção adotados; conceitual, sobre a relação entre os sistemas físico, social e ambiental abrigados no edifício. 27 Desde 1968 a UNESCO já havia concluído estudo junto a setenta e nove países-membros que a EA "não deveria constituir-se em uma disciplina específica no currículo das escolas, tendo em vista sua complexidade e interdisciplinaridade." (BRASIL, 1998, p. 28). Mas foi apenas em 1991, quando a Rio-92 se aproximava, que o MEC determinou que a EA deveria permear todo o currículo escolar e nos diferentes níveis e modalidades de ensino (p. 53).
} 
conteúdo que é próprio da disciplina. (POMBO, 2005). Nicolescu ${ }^{28}$ (2000) define a transdisciplinaridade como um conceito que diz respeito àquilo que está ao mesmo tempo entre, através e além de toda disciplina, em que o objetivo é a compreensão do mundo presente. Podese depreender das colocações desses autores que a visão sistêmica e a transdisciplinaridade têm propostas entrelaçadas.

Santos (1988) defendeu o autoconhecimento às comunidades como forma de proporcionar maturidade perceptiva e noção ampliada do bem-viver coletivo. Parafraseando-o, se "o aprofundamento do conhecimento permitiu ver a fragilidade dos pilares em que se funda" (p. 51), o diagnóstico que a autoavaliação proporciona pode levar-nos a detectar as enfermidades de cada comunidade escolar e dessa forma proporcionar procedimentos que restabeleçam sua saúde e bem-viver.

Pode-se extrair das colocações desses autores uma interessante reflexão sobre a complementaridade entre a visão ampliada "para fora" e a ampliada "para dentro". A soma de ambas deve resultar certamente numa visão completa, ou sistêmica, tão necessária para o equilíbrio desejado da sustentabilidade.

Vale ressaltar, porém, a quem possa estar motivado a avançar em direção a mudanças de hábitos ou de ampliação do ângulo de visão para um grau coletivo e sistêmico perante o meio ambiente, sociedade, recursos e tanto outros, sobre a real possibilidade de tais processos sofrerem significativo retardo, decorrente da resistência e morosidade daqueles que são desmotivados a elas, por razões subjetivas, acomodação ou interesses pessoais, como Lück nos alerta:

\footnotetext{
É necessário ter em mente que uma cultura não é mudada apenas por desejo, sendo necessário o alargamento da consciência e da competência técnica para tanto. É importante reconhecer que mesmo que as pessoas desejem participar da formulação e construção dos destinos de uma unidade social, não desejam aceitar, rapidamente, o ônus de fazê-lo, daí por que, após manifestarem esse interesse, manifestam, por meio de comportamentos evasivos, resistência ao envolvimento nas ações necessárias à mudança desejada. [...]Esse processo de resistência se explica pela desestabilização da ordem vigente e de nichos de poder, provocados pela mudança da prática social e que motivam reações demandando desacomodação geral. (LÜCK, 2011, p.20)
}

No entanto, a EA sendo "um componente essencial e permanente da educação nacional, devendo estar presente, de forma articulada, em todos os níveis e modalidades do processo educativo, em caráter formal e não-formal", segundo a Lei no. 9.795, que institui a 
Política Nacional de Educação Ambiental, resistências a mudanças em direção à sustentabilidade podem ser consideradas infrações. (BRASIL, 1999).

No sentido inverso, há mundo afora quem venha buscando se lançar em novos protocolos, como o "do berço ao berço", que preconiza uma nova matriz, onde a tríade “ambiente, equidade e economia" utilizada convencionalmente para gerir os impactos negativos após suas ocorrências, seria utilizada desde o princípio no projeto de novos produtos e serviços, o que inverteria para positivos os impactos ao meio ambiente. McDonough e Braungart chamam a isso de ecoefetividade no lugar de ecoeficiência. Nesse sistema, resíduos passam a retroalimentar ciclos da natureza e também industriais e tornam-se nutrientes tanto biológicos como técnicos. (MCDONOUGH; BRAUNGART, 2002, grifo nosso).

Capra (1982) nos esclarece dizendo que a visão de mundo mecanicista já ultrapassada não pode entender a atualidade e seus problemas sistêmicos e interdependentes, o que exige mudança e transformação profunda das instituições sociais, valores e ideias, incluindo uma “intuição não linear”, que somada ao nosso conhecimento lógico-racional seja capaz de acompanhar a teia complexa formada de problemas e aprender a trabalhar nessa interconectividade entre as diferentes disciplinas, desenvolvendo uma visão holística, sistêmica e melhor estruturada.

Da mesma forma, assim deve ser visto o edifício escolar e também, segundo Kowaltowski (2011), como "reflexo" de aspectos "que vão além da sua materialidade". Há muito mais em jogo numa instância escolar a ser percebido e considerado.

\footnotetext{
[...] a discussão sobre a escola ideal não se restringe a um único aspecto, seja de ordem arquitetônica, pedagógica ou social: torna-se necessária uma abordagem multidisciplinar, que inclua o aluno, o professor, a área de conhecimento, as teorias pedagógicas, a organização de grupos, o material de apoio e a escola como instituição e lugar. (KOWALTOWSKI, 2011, p. 11).
}

Outra vez encontro a mesma visão sutil, mas dessa vez no sistema formulado por Meadows (1999) para avaliação de sustentabilidade, com seus 12 Pontos de Alavancagem. Ao invés de julgar que o que aparentemente (intuitivamente) possa trazer resultados bons, há mecanismos contra-intuitivos para indicar os verdadeiros caminhos de desenvolvimento sustentável. Isso porque os sistemas não são lineares ou simples, são complexos. Há variáveis que nem imaginamos, atuando dentro dos "sistemas complexos". Segundo a contribuição de Meadows, é preciso reformular a visão e compreender que mais do mesmo apenas aumenta o problema. 
É curioso ver os reflexos de todas essas linhas de raciocínio rebatidos sobre os documentos que se formulam na direção da transformação do modelo de desenvolvimento e crescimento para o de sustentabilidade. As seis "premissas para a construção e implementação da Agenda 21 brasileira" (2002) demonstram bem isso:

1. estabelecer uma abordagem multissetorial e sistêmica - com visão prospectiva, entre as dimensões econômica, social, ambiental e institucional;

2. promover a sustentabilidade progressiva e ampliada. A Agenda 21 apresenta essencialmente a construção de consensos e pontes, a partir da realidade atual, para o futuro desejado; não existem fórmulas mágicas e a sustentabilidade será resultado de uma transição, e não de uma transformação abrupta;

3. promover o planejamento estratégico participativo - a agenda 21 não pode ser um documento de governo, e sim um projeto de toda a sociedade brasileira, pois só assim serão forjados compromissos para sua implementação efetiva;

4. estabelecer o envolvimento constante dos atores no estabelecimento de parcerias - o processo de construção e implantação da agenda deve sempre estar aberto à participação e envolvimento das pessoas, instituições e organizações da nossa sociedade;

5. entender que o processo é tão importante como o produto - os maiores ganhos virão das novas formas de cooperação e diálogo entre os atores sociais e da eficiência e eficácia dos resultados pretendidos;

6. estabelecer consensos e superar os entraves do atual processo de desenvolvimento - a construção da agenda demanda a mediação e a negociação como forma de se avançar sobre os conflitos e contradições dos processos, para que se lance luz sobre os grandes entraves que devem ser enfrentados, para caminharmos rumo a sustentabilidade é fundamental que as ações sejam pactuadas. (BRASIL, 2002, p. 26).

Certamente, a multiplicidade brasileira de realidades sociais, econômicas, culturais, climáticas, geográficas, políticas, históricas tenha sido um dos motivos pelos quais nossa versão da Agenda 21 traga esse teor orgânico da construção democrática e tenha sido concluído somente após dez anos. O desafio desse exercício possivelmente tenha sido proporcional à essa diversidade que o Brasil apresenta e, ao mesmo tempo, uma experimentação real de como exercer o conceito da sustentabilidade na prática sistemática do diálogo.

Dificuldade similar em aplicar agendas globais é encontrada não apenas no Brasil. Embora sejam universais enquanto demandas globais, há contextos variáveis ao redor do mundo que exigirão dedicação de seus atores para enquadrá-las, o que de toda forma é esperado enquanto mobilização mundial. Franquesa-Soler e Sandoval-Rivera (2019) contribuem mostrando um estudo de caso recente em comunidades no sul do México com herança cultural indígena maia para implantação de uma rede de escolas sustentáveis, as Escuelas Ya'ax ${ }^{29}$, que utiliza 5 ODS's da Agenda 2030 como referência para essencialmente alcançar "proteção e melhoria do próprio meio ambiente" capacitando os alunos numa metodologia de mentoria em 
lideranças do "saber científico e o saber tradicional/ indígena" e também em habilidades para a autosuficiência sustentável, com intuito de se irradiar para as suas comunidades locais. Segundo os autores, "não é fácil" aplicar os ODSs "do global ao local”. Mas "de baixo para cima, os ODS deixam de ser uma agenda global e se tornam uma ferramenta analítica que ajuda a explorar as complexidades dos contextos locais e, assim, conectá-los globalmente”. (p. 110111).

\subsubsection{CONSIDERAÇÕES FINAIS}

Junto aos autores teóricos citados, identifico linhas de pensamento e contribuições muito alinhadas com diversas passagens das experiências pregressas relatadas e que jogam luz sobre demandas comuns na macro escala global, mas também na micro escala, como a da instância escolar - resistência a mudanças, sistemas complexos, problemas sistêmicos e especialização foram aspectos presentes no contexto escolar vivenciado, como possivelmente também podem ser no de outras escolas, e que trazem grandes desafios para a transição dos espaços físicos escolares para o conceito Escola Sustentável.

Felizmente, nesse mesmo repertório teórico pude identificar caminhos potenciais e recursos cientificamente sólidos para solucionar tais demandas - sinergia, pensamento abrangente, visão sistêmica, autoconhecimento, multi e interdisciplinaridade, ecoefetividade e avaliação de sustentabilidade - que se exercitados pela comunidade sob critérios metodológicos conscientes e conjuntos, podem contribuir progressivamente para sanar as demandas persistentes e rumar em direção à evolução do espaço físico escolar pelos parâmetros de sustentabilidade, ou conceito Escola Sustentável. 


\section{RESULTADOS E DISCUSSÃO}

Os dados obtidos são resultantes do processo metodológico de pesquisa descrito anteriormente, que foi aplicado sobre os documentos e sobre bibliografias selecionadas, ambos de procedência nacional e internacional. A identificação das unidades de registro em tais textos primários e secundários, organizadas em categorias e processadas segundo a metodologia descrita, permitiu reunir de diversas partes atuantes em pesquisa e execução recentes de Escolas Sustentáveis ao redor do mundo, representadas pelas literaturas selecionadas e abaixo relacionadas, contribuições importantes à construção de um contorno universalizado para o conceito Escola Sustentável.

\subsection{TEXTOS PRIMÁRIOS E SECUNDÁRIOS}

Foi adotada a sequência cronológica das publicações para a análise documental e bibliográfica dos textos e assim se apresentam no arquivo de fichamento, conforme modelos apresentados no Capítulo 3, em abas individuais para cada título, aqui apresentadas, brevemente, as suas referências e respectivos conceitos-chave:

UNESCO; IBAMA. Educação ambiental: as grandes diretrizes da Conferência de Tbilisi. Brasília: 1997. 154 p.

Apresentação das principais diretrizes formuladas pela Conferência de Tbilisi para a organização e o desenvolvimento da educação ambiental.

BRASIL, Ministério da Educação e do Desporto - Coord. de Educação Ambiental. Implantação da Educação Ambiental no Brasil. Brasília, DF, 1998. 166p.

O livro reúne dados históricos, experiências e bagagens junto a diversos atores do cenário da EA ao longo de algumas décadas do século XX. Traz compilações de diversos eventos marcantes na linha histórica da EA, no Brasil e no mundo, além de depoimentos relacionados a eles e à EA.

BRASIL. Lei no. 9.795, de 27 de abril de 1999. Dispõe sobre a educação ambiental, institui a Política Nacional de Educação Ambiental e dá outras providências. In: Educação Ambiental: aprendizes de sustentabilidade. Brasília, DF, 2007. 95-99 p.

Dispõe especificamente sobre a Educação Ambiental (EA) e institui a Política Nacional de Educação Ambiental (PNEA). Estabelece princípios e objetivos fundamentais da EA enquanto descreve as atividades para sua implantação em todo o âmbito esducacinal brasileiro.

BRASIL. Ministério da Educação. Secretaria de Educação Continuada, Alfabetização e Diversidade. Tratado de Educação para Sociedades Sustentáveis e Responsabilidade Global. In: Educação Ambiental: aprendizes de sustentabilidade. Brasília, DF, 2007. p. 103-107. 
Tratado de Educação Ambiental para Sociedades Sustentáveis e Responsabilidade Global, elaborado no âmbito da sociedade civil internacional durante a RIO 92 e inclui planos de ação.

LEGAN, Lúcia. A escola sustentável: eco-alfabetização pelo ambiente. São Paulo: Imprensa Oficial do Estado de São Paulo; Pirenópolis: Instituto de Permacultura e Ecovilas do Cerrado (IPEC), 2007. 172 p.

Levantar discussões sobre o desenvolvimento sustentável nas salas de aula. Culturas tradicionais e indígenas e tecnologias e informações da ciência moderna lado a lado. Observação e a compreensão da natureza.

BRASIL. Ministério da Educação, Secretaria de Educação Continuada, Alfabetização e Diversidade. Processo Formativo Escolas Sustentáveis e Com-Vida. Brasília, DF, 2010. 45 p.

Processo formativo em EA desenvolvido pela antiga SECADI-MEC para formar escolas sustentáveis e COM-Vida, voltado à comunidade escolar como um todo.

GORDON, Douglas E. Green Schools as High-Performance Learning Facilities. National Clearinghouse for Educational Facilities, 2010.

Apresentação acerca do conceito das green schools e de alguns sistemas de avaliação da sustentabilidade em escolas existentes no mercado dos E.U.A.

BRASIL. Ministério do Meio Ambiente; Ministério da Educação. Recomendação Conama n⿳11, de 04 de maio de 2011. In: Educação Ambiental por um Brasil sustentável - ProNEA: marcos legais e normativos - Brasília, DF, MMA 2018. p. 68-70.

Recomenda diretrizes para a implantação, funcionamento e melhoria da organização dos Centros de Educação Ambiental-CEA, e dá outras orientações.

KUUSKORPI, M.; GOnZÁleZ, N. Cabellos. The Future of the Physical Learning Environment: School Facilities that Support the User. CELE Exchange, Centre for Effective Learning Environments, 2011/11. Paris, OECD Publishing, 2011.

Espaços dinâmicos de ensino podem favorecer a atualização do modelo educacional convencional em espaços físicos engessados, em favor das tecnologias avançadas que vêm sendo incorporadas pedagogicamente.

JORGE Graça, F..; COSTA, Marta M. da. High Performance School Buildings in Portugal: A Life Cycle Perspective. CELE Exchange, Centre for Effective Learning Environments, 2011/09. Paris: OECD Publishing, 2011.

Destaca-se a atenção dada a sistemas de gerenciamento e monitoramento da energia para obter eficiência energética conjugada à contextualização pedagógica e da manutenção sistemática das edificações com participação dos alunos.

MOORE, K. Schools of the Future Initiative in California. CELE Exchange, Centre for Effective Learning Environments, 2011/07. Paris: OECD Publishing, 2011.

Medidas elaboradas em rede multidisciplinar colaborativa para criação de novo padrão de escolas sustentáveis na Califórnia. 
Estabelece as Diretrizes Curriculares Nacionais para a Educação Ambiental, que reconhecem a relevância e a obrigatoriedade da Educação Ambiental em todas as suas etapas e modalidades.

BRASIL. Ministério da Educação. Secretaria de Educação Continuada, Alfabetização, Diversidade e Inclusão. Vamos cuidar do Brasil com escolas sustentáveis: educando-nos para pensar e agir em tempos de mudanças socioambientais globais. Brasília, DF, 2012. 46 p.

A publicação direciona questionamentos à comunidade escolar acerca da sustentabilidade e a convida a "arreagaçar as mangas" para agir em suas instâncias, propondo ações de alinhamento do espaço físico escolar, do currículo e da sua gestão com a sustentabilidade.

BRASIL. Ministério da Educação; Secretaria de Educação Continuada, Alfabetização, Diversidade e Inclusão. Manual Escolas Sustentáveis - Resolução CD/FNDE Nº 18, de 21 de maio de 2013. Brasília, DF, 2013.

Orientações operacionais para apoiar a implementação da Resolução CD/FNDE no 18, de 21 de maio de 2013, que destina recursos financeiros, via PDDE, a escolas públicas municipais, estaduais e distritais de educação básica, a fim de favorecer a melhoria da qualidade de ensino e a promoção da sustentabilidade socioambiental nas unidades escolares.

BRASIL. LEI no 13.005, DE 25 DE JUNHO DE 2014: aprova o Plano Nacional de Educação - PNE e dá outras providências. Brasília, DF, 2014.

Conjunto de 20 metas voltadas a atender o Art. 214 da Constituição Federal a serem aferidas em cada estado a cada 10 anos.

BRASIL. Ministério da Educação; Secretaria de Educação Continuada, Alfabetização, Diversidade e Inclusão; Diretoria de Políticas de Educação em Direitos Humanos e Cidadania; Coordenação-geral de Educação Ambiental. Programa Dinheiro Direto na Escola - PDDE Escolas Sustentáveis: guia de orientações operacionais. Brasília, DF, 2014.

Orientações operacionais para o preenchimento do plano de ação para assistência financeira, conforme a regulamentação do PDDE, a fim de favorecer a melhoria da qualidade de ensino e a promoção da sustentabilidade socioambiental nas escolas públicas de educação básica, de acordo com a Resolução FNDE nº 18, de 03 de setembro de 2014

BRASIL. Ministério das Relações Exteriores. Negociações da Agenda de Desenvolvimento Pós- 2015: Elementos orientadores da posição brasileira. 2014. 30 p.

Medidas orientadoras para a negociação da Agenda Pós-2015 elencadas pelo grupo de trabalho interministerial brasileiro, que visam atender aos Objetivos de Desenvolvimento Sustentável - ODS, por uma iminência ambiental a partir da educação das novas e futuras gerações.

USGBC. LEED 2009 For Schools New Construction and Major Renovations. USGBC, 2016. 109 p. 
Parâmetros de avaliação da sustentabilidade em edificações escolares em formato checklist visando promover práticas saudáveis, duráveis, acessíveis e ambientalmente corretas em projetos e construção de edifícios.

MAHAT, Hanifah et al. Model development on awareness of education for sustainable schools development in Malaysia. Indonesian Journal of Geography, v. 48, n. 1, p. 37-46, 2016.

Pesquisa quantitativa para verificação da eficácia do programa SLAAS nas escolas da Malásia em gerar conhecimento, atitude e comportamento de EDS.

TUCKER, Richard; IZADPANAHI, Parisa. Live green, think green: Sustainable school architecture and children's environmental attitudes and behaviors. Journal of Environmental Psychology, v. 51, p. 209-216, 2017.

$\mathrm{O}$ artigo testa a hipótese de que as crianças que frequentam escolas projetadas para a sustentabilidade terão atitudes e comportamentos em relação ao meio ambiente que são mais pró-ambientais do que aqueles que frequentam escolas com projetos convencionais.

BRASIL. Ministério do Meio Ambiente; Ministério da Educação. Educação Ambiental por um Brasil sustentável - ProNEA: marcos legais e normativos - Brasília, DF, MMA 2018.104 p.

$5^{\text {a }}$ edição de 2018 do Programa Nacional de Educação Ambiental - ProNEA, consolidada após consulta pública e o IX Fórum Brasileiro de Educação Ambiental realizados em 2017, ainda vigente.

SHARMA, P. K. et al. Positive actions for the sustainable development goals. Foundation for Environmental Education, 2018. 48 p.

Apresenta os propósitos do programa Eco-Schools, alguns cases que exemplificam sua aplicação em diversas partes do mundo, além de descrever como ele se aplica em cada um dos ODS.

OECD. OECD School User Survey: Improving Learning Spaces Together. 2018. 51 p.

Questionário gratuito de autoavaliação sobre o espaço físico escolar, direcionado a alunos, professores e diretores de escolas pelo Programa de Avaliação de Ambientes de Aprendizagem da OCDE.

GOUGH, Noel \& GOUGH, Annette. The Green Schools Movement Around the World. In: PRESENTATION TO ASIAN STUDIES FACULTY AND STUDENTS, UNIVERSITY OF WESTERN AUSTRALIA, 2019.

Apresentação de políticas públicas de educação ambiental em 19 países ao redor do mundo, suas oportunidades e desafios.

FRANQUESA-SOLER, Montserrat; SANDOVAL-RIVERA, Juan Carlos A. Mentoring Program to achieve SDGs in local contexts: a case study in communities from southern Mexico. Sustainability: The Journal of Record, v. 12, n. 2, p. 109-114, 2019.

Descreve a metodologia de mentoria para formar líderes em EDS nas escolas Ya'ax no sul do México com heranças tradicionais da cultura maia para implantar sustentabilidade ao contexto cultural local utilizando ODSs como referência. 
MOORE, Mary et al. Extending communities of practice: a partnership model for sustainable schools. Environment, Development and Sustainability, v. 21, n. 4, p. 1745-1762, 2019.

A comunidade de prática $(\mathrm{CoP})$ dentro da escola, a implantação de sistema de gestão ambiental (EMS), as parcerias HEI (universidades e instituições do terceiro setor) e as indústrias podem formar um modelo estável e sustentável para construção de conhecimentos em sustentabilidade de forma continuada para a formação de professores, diretores, funcionários, alunos das escolas sustentáveis.

FUNDAÇÃO PARA O DESENVOLVIMENTO DA EDUCAÇÃO (FDE), Portal eletrônico. Apresenta serviços sustentáveis para escolas. 2019.

Portal eletrônico da Fundação para o Desenvolvimento da Educação - FDE que dedica todo um segmento à sustentabilidade nas edificações de escolas que projeta e relaciona procedimentos adotados para uso responsável de água, energia, materiais, entre outros aspectos, além de disponibilizar manuais técnicos orientativos.

ASSOCIATION FOR THE ADVANCEMENT OF SUSTAINABILITY IN HIGHER EDUCATION (AASHE). Stars ${ }^{\circledR}$ Technical Manual. Version 2.2. AASHE: Philadelphia, jun. 2019. 322 p.

Estrutura voluntária de autoavaliação para ajudar faculdades e universidades a rastrear e medir seu progresso de sustentabilidade.

HARB, S.; ELHAGGAR, S. M.; SEWILAM, H. Developing sustainable school guidelines: the case of Egypt. In: E3S Web of Conferences. EDP Sciences, 2019.

Reunir parâmetros de sustentabilidade para a avaliação do espaço físico escolar a fím de sugerir modelo de avaliação compatível com a realidade local (Egito).

COLE, Laura B.; HAMILTON, Erin M. Can a green school building teach? A pre-and post-occupancy evaluation of a teaching green school building. Environment and Behavior, 2020, v. 52, n. 10, p. 1047-1078.

A informação transmitida ao usuário de TGB (Teaching Green Buildings) sobre seus benefícios e propriedades é necessária para gerar envolvimento e aumento do GBK (Green Building Knowledge) e do ERB (Environmentally Responsible Behaviors), pois o edifício por si não ensina sozinho.

\subsubsection{UNIDADES DE REGISTRO}

$\mathrm{Na}$ medida em que as literaturas elencadas acima foram analisadas, segmentos de conteúdo representativos das questões investigativas e dos objetivos desta pesquisa foram sendo transferidos para suas fichas respectivas e neles destacadas com grifos as unidades de registro, como pode ser acompanhado em detalhes acessando o domínio informado na seção anterior.

Foram obtidas ao todo 1.161 unidades de registro, ora formadas por termos menores, ora, por extratos maiores dos textos, de acordo com a disposição original encontrada, de forma a evitar a redução indesejada no sentido expressado pelos autores. No entanto, conforme foi 
visto no Capítulo 3, na ocorrência de unidades de análise idênticas e repetidas, como ocorre com os termos eficiência energética, bicicletário ou acessibilidade; ou redundantes, como os termos indivíduo e coletividade e posturas individuais e coletivas foram considerados de forma unificada enquanto unidades de registro, optando-se sempre por uma terminologia mais abrangente, no caso participação individual e coletiva, permanente e responsável, que por sua vez somou-se a outras unidades sobre o tema para gerar a sentença final, responsabilidade e o engajamento individual e coletivo na transformação local e global, conforme segue:

indivíduo e a coletividade $x$ responsabilidade individual e coletiva a nível local, nacional e planetário x posturas individuais e coletivas $\mathrm{x}$ incentivar a participação individual e coletiva $\mathrm{x}$ exercício de participação $\mathrm{x}$ responsabilidade e o exercício consciente da cidadania + exercício da cidadania local e planetária + participação individual e coletiva, permanente e responsável + responsabilidade e o engajamento individual e coletivo na transformação local e global = $\underline{\text { responsabilidade e o engajamento individual e coletivo na transformação local e }}$ global

Notam-se que outras unidades de registro dentro dessa mesma análise são relativas ao mesmo tema, no caso, a conjugação encontrada entre o indivíduo x local e coletividade x global, além de termos periféricos complementares do sentido, como participação, responsabilidade, engajamento, transformação, que foram consideradas na soma final.

Esse exemplo descreve o trabalho de tratamento das unidades de registro e o exercício de síntese dos dados colhidos, destilando as informações de uma forma precisa.

Noutro exemplo, os termos aquecimento solar de água e instalar paineis solares foram anulados pelo termo aquecedores solares pela redundância que apresentam dentro do conjunto de unidades reunidas ao redor do tema - empregos da energia solar na escola - que da mesma forma foi somado a outras unidades complementares, resultando:

aquecedores solares x aquecimento solar da água x instalar painéis solares + incentivo à utilização de energia solar + painéis solares térmicos para produzir água quente para cozinhas escolares quanto em instalações esportivas + fogão solar = apoia a utilização da energia solar ao adotar um fogão solar para preparo de alimentos e aquecedores solares para produção de água quente em vestiários e cozinhas

Ainda para exemplificar o procedimento, outro tema identificado - água da chuva exigiu reunir diversas unidades de registro para completar o assunto. A supressão de termos redundantes e repetidos não foi tão significativa em relação ao número de dados complementares colhidos sobre o tema e que somados definiram mais um princípio, conforme segue:

redução do uso de abastecimento de água municipal + uso de águas servidas + água da chuva como um recurso + controlar águas pluviais x utilização da água da chuva x eaptação de água de chuva x eaptação de chuva + captação de águas pluviais + retenção e o aproveitamento das águas pluviais + coleta das águas de chuva incidentes na cobertura + encaminhamento para um reservatório enterrado + cisterna para captação de água da chuva + reservatórios para retenção das águas de chuva x instalar tanques de água + distribuição [da água de chuva dos telhados tratada] para os pontos de consumo - bacias sanitárias e mictórios - através de tubulação exclusiva e com cor diferenciada + reutilizar a água da chuva para usos não potáveis, como irrigação de jardins, descarga de vasos sanitários e mictórios + sistema de armazenamento e reutilização da água de chuva para a irrigação de hortas, para a limpeza de pisos e em vasos sanitários = valorizar a água da chuva como um recurso 
para a redução do consumo de água servida pela rede pública municipal construindo um sistema para coleta nas coberturas, retenção em telhados verdes, armazenamento em cisternas, tratamento para descontaminação, distribuição em tubulação exclusiva e identificada para as descargas de bacias sanitárias e mictórios, irrigação de jardim, de hortas e lavagem de pisos

Dessa forma, pouco a pouco, foram sendo obtidos os contornos dos princípios da Escola Sustentável.

Outras formas de processamentos também aplicadas permitiram destilar os dados de forma objetiva sem prejudicar seus conteúdos. Nota-se, por exemplo, que certos termos por vezes são utilizados com maior abrangência por uma literatura em relação a outra. Nestes casos, tais unidades de menor abrangência e já contidas no significado mais completo das primeiras, foram suprimidas e eliminadas por estas, como por exemplo coleta e destinação ambientalmente adequada de resíduos (mantida) destinação apropriada de resíduos da escola (suprimida), ou políticas, metodologias e práticas de educação ambiental (mantida) e práticas no ambiente escolar (suprimida). Dessa mesma forma, muitas outras ocorrências desse tipo foram processadas.

Houve diversos casos em que unidades de registro não se conjugaram com outras por serem de assuntos muito específicos:

coletor para pilhas e bateria

níveis de formaldeído nas escolas devem ser mantidos muito baixos educação informal em edifícios verdes avaliação ambiental do solo local e remediação, caso contaminado portas, torneiras e banheiros sem toque

Em outros casos, apenas desejou-se manter destaque de seu foco com o seu isolamento, por se apresentarem como máximas, ou colocações incontestáveis:

é de interesse global promover e desenvolver escolas sustentáveis meio ambiente começa pelo entorno imediato promover a paz não comprar se não for necessário não poluir ou desperdiçar água

Em determinado momento, a leitura passou a encontrar muitas recorrências entre os conteúdos de literatura, o que evidenciou o "princípio da saturação", demonstrando ser um momento para concluir a coleta de unidades de registro, conforme Pires (2008) orienta: "quando após aplicações sucessivas, os dados não acrescentam nenhuma propriedade nova ao conceito, pode-se dizer que o conceito criado está saturado." (p. 198).

Após tais processamentos as unidades de registro resultaram em 482, de forma a objetivar o trabalho de construção dos princípios do conceito Escola Sustentável e dar precisão à realização dessa tarefa, o que demandará um último tratamento de síntese. Mas já nesta extração resultante, foi possível perceber alinhamento entre autores e sincronicidade sobre 
inúmeros tópicos por eles abordados, como em assuntos relativos à capacitação, gestão, métodos, procedimentos, entre outros. Essa convergência entre contribuições de autores ao redor do mundo trouxe importante significação à esta pesquisa, uma vez que a grande maioria das ocorrências foi de dados complementares entre si, que uma vez somados, deram profundidade e detalhamento a um arcabouço informativo, formado pelas unidades de registro finais resultantes, num mosaico global elaborado para a construção do conceito Escola Sustentável.

\subsubsection{CATEGORIAS}

Assuntos diversos e pertinentes à construção de um contorno global do conceito Escolas Sustentáveis foram sendo identificados nesses recortes. Tais unidades de registro foram sendo agrupadas segundo esses assuntos - as categorias de análise - de forma que 16 categorias (Tabela 13) emergiram desse processo gradual e intensivo de examinação e de organização de dados dessa análise de conteúdo, a seguir apresentadas:

Tabela 13 - Categorias de análise

\begin{tabular}{|c|c|c|}
\hline $\begin{array}{l}\sum_{1}^{\infty} \\
\sum_{0}^{0} \\
0 \\
0 \\
0\end{array}$ & IDENTIDADE & $\begin{array}{l}\text { Refere-se ao passo inicial, em que a comunidade busca o seu } \\
\text { autoconhecimento enquanto instituição: valores, tradições, } \\
\text { influências, referências e experiências adquiridas. Volta seu } \\
\text { primeiro olhar para dentro de suas vivências atuais ou } \\
\text { passadas e identifica aspectos locais, etnográficos e também } \\
\text { idiossincráticos que compõem o dia-a-dia da sua comunidade. } \\
\text { Hábitos, costumes e rotinas que denotem traços } \\
\text { característicos próprios. }\end{array}$ \\
\hline 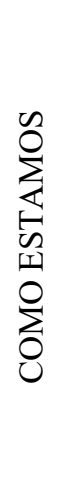 & MARCO ZERO & $\begin{array}{l}\text { Vem aprofundar o autoconhecimento adquirido para um } \\
\text { levantamento concreto da situação física, ambiental e social } \\
\text { atual da escola. O mapeamento das demandas e potenciais da } \\
\text { escola poderá ser elaborado pela sua comunidade seguindo o } \\
\text { Guia de Princípios da Escola Sustentável, produto final deste } \\
\text { trabalho. A participação e o engajamento da comunidade } \\
\text { como um todo segue imprescindível também neste momento. }\end{array}$ \\
\hline
\end{tabular}




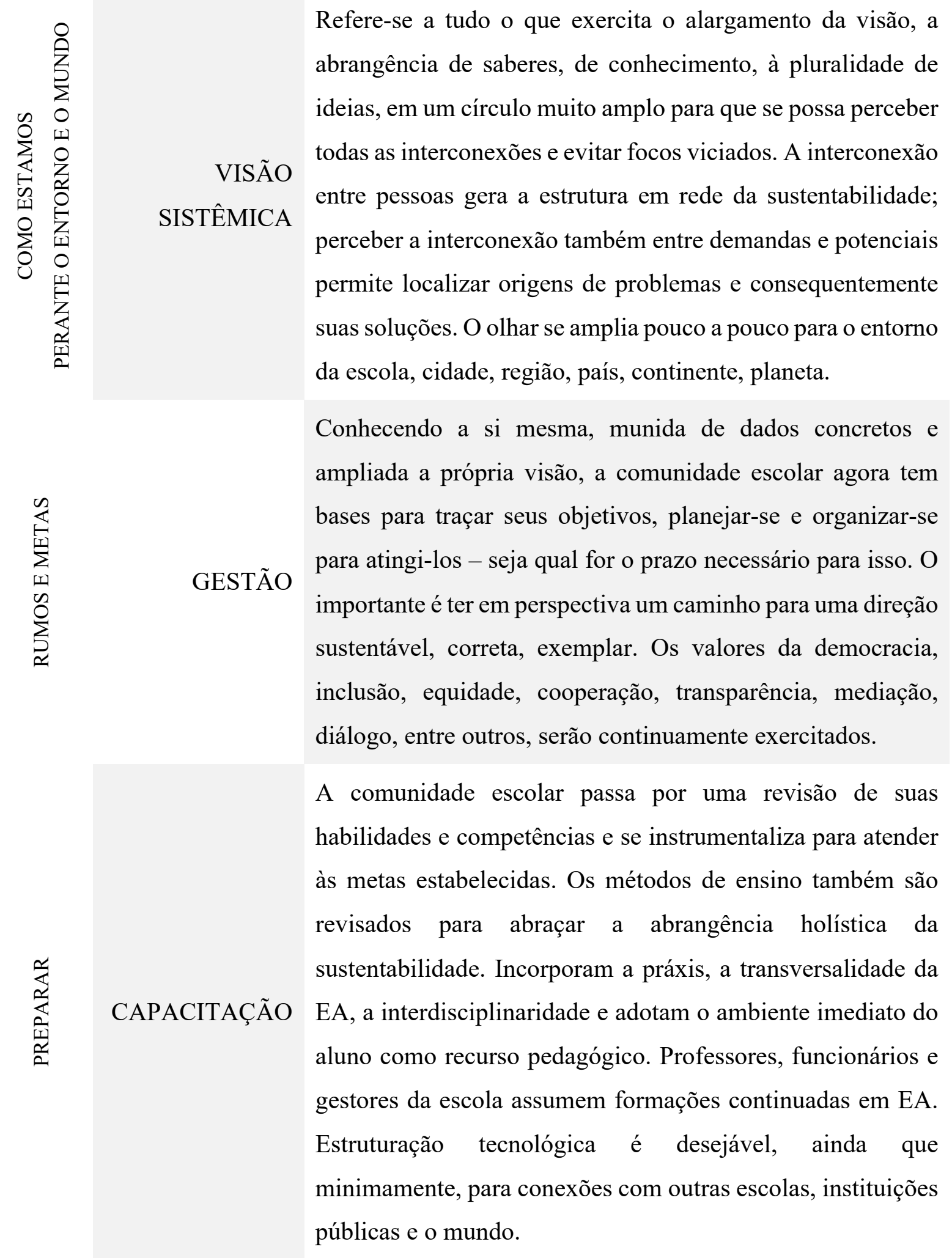


Apoios e parcerias junto a profissionais multidisciplinares, empresas e indústrias, preferencialmente locais e alinhados com a sustentabilidade, e instituições, que possam somar força ao processo de transição, tornam-se imprescindíveis no processo para orientar ou executar com propriedade técnica, REDE segurança e durabilidade muitas das ações de melhorias pretendidas, especialmente relacionadas ao espaço físico escolar. Parcerias internas de colaboração entre professores, funcionários, gestores são igualmente essenciais. Trocas junto a outras comunidades escolares, de locais à estrangeiras, são também parte integrante da visão abrangente desejada.

Relaciona tudo o que diz respeito à qualidade do espaço físico escolar, enquanto laboratório e instrumento educador para a sustentabilidade. A arquitetura bioclimática, eco-técnicas e conforto, uma vez aplicados, podem reverter demandas em

ESPAÇO potenciais e adequar os ambientes aos princípios da Escola EDUCADOR Sustentável, transformando gradualmente o meio ambiente escolar num cenário real de sustentabilidade, que ensina pelo exemplo. É uma das principais ações estruturantes do processo sequencial de implantação da sustentabilidade na escola por ser parte das vivências pedagógicas.

Melhorias no ambiente físico e social trazem segurança e bem-estar nas pessoas dentro da comunidade escolar, o que é essencial ao processo de ensino/ aprendizado. Praticar a paz, higiene, alimentação saudável e reduzir riscos à saúde é um direito e também um dever de todos, mas para tanto necessita de ser identificado em pormenores e incorporado aos hábitos e rotinas diárias de todos os atores da escola, sem exceção. A conscientização coletiva das implicações que hábitos e conceitos danosos têm sobre a saúde física, espiritual e mental é uma ação importante para a mudança. 


\begin{tabular}{|c|c|c|}
\hline 怘 & $\begin{array}{r}\text { CONSUMO E } \\
\text { RESÍDUOS }\end{array}$ & $\begin{array}{l}\text { Hábitos passivos profunda reformulação são os relativos ao } \\
\text { que se compra e se descarta, ciclo vicioso destrutivo que } \\
\text { ostensivamente permanece no cenário global, embora as } \\
\text { ações dos } 5 \text { "R" } 30 \text { e a logística reversa busquem, senão } \\
\text { revertê-lo, ao menos estabilizar o esvaziamento de fontes não } \\
\text { renováveis, poluição, riscos à saúde pública e outros } \\
\text { impactos. Torna-se imperativo compreender a origem do } \\
\text { consumismo, imunizar-se de seus efeitos e realizar compras } \\
\text { responsáveis e sustentáveis. Lixo torna-se recurso sob a ótica } \\
\text { da sustentabilidade, outro exercício de revisão de conceitos. }\end{array}$ \\
\hline 导 & ENERGIA & $\begin{array}{l}\text { Compreender os custos públicos e ambientais para a geração } \\
\text { e fornecimento de energia elétrica é peça-chave para a } \\
\text { mudança de hábitos tanto na escolha do padrão de obtenção } \\
\text { da energia como no seu consumo diário. Há alternativas de } \\
\text { acessórios economizadores e de tecnologias limpas de } \\
\text { geração energética disponíveis a serem estudados e } \\
\text { incorporados mediante ajustes técnicos devidamente } \\
\text { capacitados e planejamento financeiro para tal. A } \\
\text { conscientização indistintamente coletiva permanece sendo } \\
\text { uma premissa para essa ação de mudança. }\end{array}$ \\
\hline 这 & $\begin{array}{l}\text { ÁGUA E } \\
\text { ESGOTO }\end{array}$ & $\begin{array}{l}\text { Assim como o lixo, o esgoto passa a ser visto como recurso e, } \\
\text { no caso, ainda como água. Diversas tecnologias bioecológicas } \\
\text { de baixo custo para tratamento de águas cinzas ou negras } \\
\text { agregam valor e minimizam impactos diversos. E assim como } \\
\text { energia, saber como a água chega na torneira e os riscos que } \\
\text { as mudanças climáticas iminentes podem trazer sobre o seu } \\
\text { fornecimento é essencial para eliminar desperdícios e saber } \\
\text { como armazenar e utilizar águas pluviais. Respeitar o ciclo } \\
\text { hidrológico, facilitando a infiltração das águas das chuvas no } \\
\text { solo, intensificando a vegetação, preservando nascentes, rios } \\
\text { e córregos são parte de inúmeras possíveis ações. }\end{array}$ \\
\hline
\end{tabular}

30 A Política ou Pedagogia dos 5R's recebeu essa nomenclatura devido à junção das iniciais das palavras "Repensar", "Recusar", "Reduzir", "Reutilizar" e "Reciclar". 
Refere-se essencialmente à inclusão definitiva do elemento natural no cenário escolar, da calçada às coberturas, conforme possibilidades tecnicamente e financeiramente viáveis. São possíveis ações: incorporar os ecossistemas do entorno no repertório escolar, enquanto ações de pesquisa, de conservação ou de restauração acerca da sua biodiversidade ou da integridade do solo perante efeitos erosivos ou contaminantes e a arborização como outra fundamental ação estruturante, que se soma a outras ações ambientais e de conforto na escola.

Refere-se a ações voltadas a minimizar os muitos impactos ambientais, sociais e urbanos negativos causados especialmente pelo transporte por automóveis em escolas urbanas. Algumas ações de logística interna da comunidade escolar, intervenções urbanas junto ao entorno da escola, e também relativas à itens de segurança podem ser planejadas e executadas pela comunidade escolar junto a parcerias para transformar demandas em soluções e torná-las referências para outras escolas a replicarem, de forma a promover a mitigação de congestionamentos de veículos poluentes, geração de ruídos e acidentes nas cidades.

O bom desempenho físico esperado de um edifício e de todas as suas instalações ao longo de seu ciclo de vida depende de uma estrutura de operação equipada para atender inúmeras ações preventivas e corretivas dentro da escola. Todas as intervenções de outras ações que possam vir a ser executadas

\section{遮 MANUTENÇÃO} no espaço físico escolar segundo o conceito da sustentabilidade devem necessariamente prever e programar as respectivas ações futuras de manutenção, ainda que sejam minimizadas. Diagnósticos de controle sobre consumos, equipamentos ou ambientes podem ser ações de elevada contextualização pedagógica. 


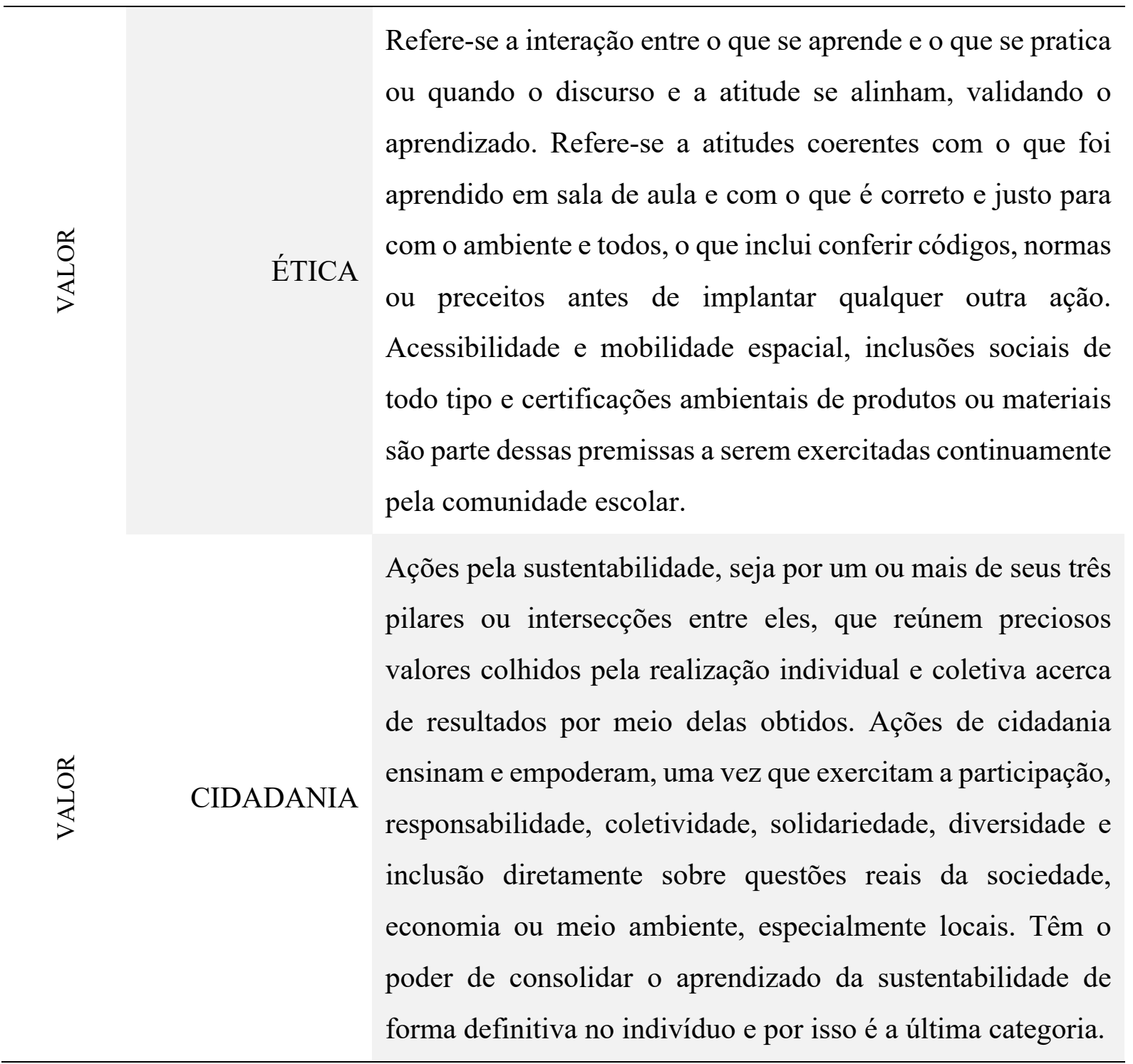

Fonte: Yara Santucci Barreto, 2021

A diversidade de temas das categorias reflete a abrangência da sustentabilidade ao recolherem as mais diversas unidades de registro sobre aspectos ambientais, materiais, humanos, culturais, operacionais, entre tantos outros encontrados nas literaturas acerca das questões de pesquisa. A redução do número de categorias acabaria por comprometer tal riqueza e também contradizer a complexidade imanente ao conceito da sustentabilidade e essencial a sua real compreensão e exercício.

Algumas outras categorias foram testadas antes desse elenco final. Contexto local ou Currículo, são exemplos. Acabaram se revelando transversais e sendo absorvidas por diversas outras categorias, como Identidade, Paisagem, Cidadania no primeiro caso; no segundo caso, Currículo, foi ainda mais ampla a disseminação, senão total, o que confirmou ser mesmo transversal o propósito da EA e do ensino da sustentabilidade, pois todas as categorias guardam 
aspectos passíveis de contextualização pedagógica - o que curiosamente pensava ser uma suposição íntima em minha experiência pregressa.

Inicialmente as categorias foram dispostas sem nenhuma sequência, apenas seguiram emergindo conforme as unidades de registro eram reunidas. Após um maior acúmulo desses dados e o consequente enriquecimento informativo de cada uma delas - mas também a organização e reorganização por vezes de diversas unidades de registro, o que exercitou muitas reflexões para chegar a suas posições finais - foi possível detectar uma sequência entre as categorias; um processo sequencial, ou roteiro, destacado pela primeira coluna da Tabela 13 (Quem Somos; Como Estamos; Como Estamos Perante o Entorno e o Mundo; Rumos e Metas; Preparar; Estruturar; Ações; Valores), que poderá auxiliar o processo de transição das escolas para a sustentabilidade. A disposição se apresenta linear pela própria lógica que descreve e assim deve ser assimilada em teoria enquanto início, meio e fim de um processo, mas certamente poderá ser percorrida na prática de forma não-linear quantas forem as implicações próprias de cada comunidade escolar ao longo de seu processo.

Vale pontuar ainda que o número de incidências de unidades de registro que compõem cada categoria variaram muito, o que não significa serem relativas a temas mais ou menos importantes, mas apenas mais ou menos citados ou lembrados. Por essa razão a Tabela 13 buscou apresentar as categorias de forma equivalente em tamanho e conteúdo, com a intenção de equalizar as suas abrangências e papeis perante o processo, que assim devem ser consideradas para um resultado sustentável.

O gráfico da Figura 9 demonstra essas variações entre as categorias, antes e depois das supressões por repetições e redundâncias entre as unidades de registro que as compõem, representadas respectivamente pelos tons claro e escuro no gráfico e revela o quão frequente cada categoria é citada, o que indica as tendências de maior atenção ou preocupação por parte dos autores das literaturas.

A comparação dos indicadores entre ambas circunstâncias que esse gráfico apresenta permite localizar quais as categorias de assuntos que possuem mais ou menos atenção e quais as que demonstram maiores ou menores diretrizes - após supressão de repetições, redundâncias e dados complementares dentro de um mesmo tema, ou resultantes.

Resultantemente, essa amostragem global traz respostas e um repertório amplo de discussão acerca da questão de pesquisa principal e complementares investigadas (Tabela 1), a saber: 
Figura 9 - Categorias segundo as incidências totais e resultantes das unidades de registro

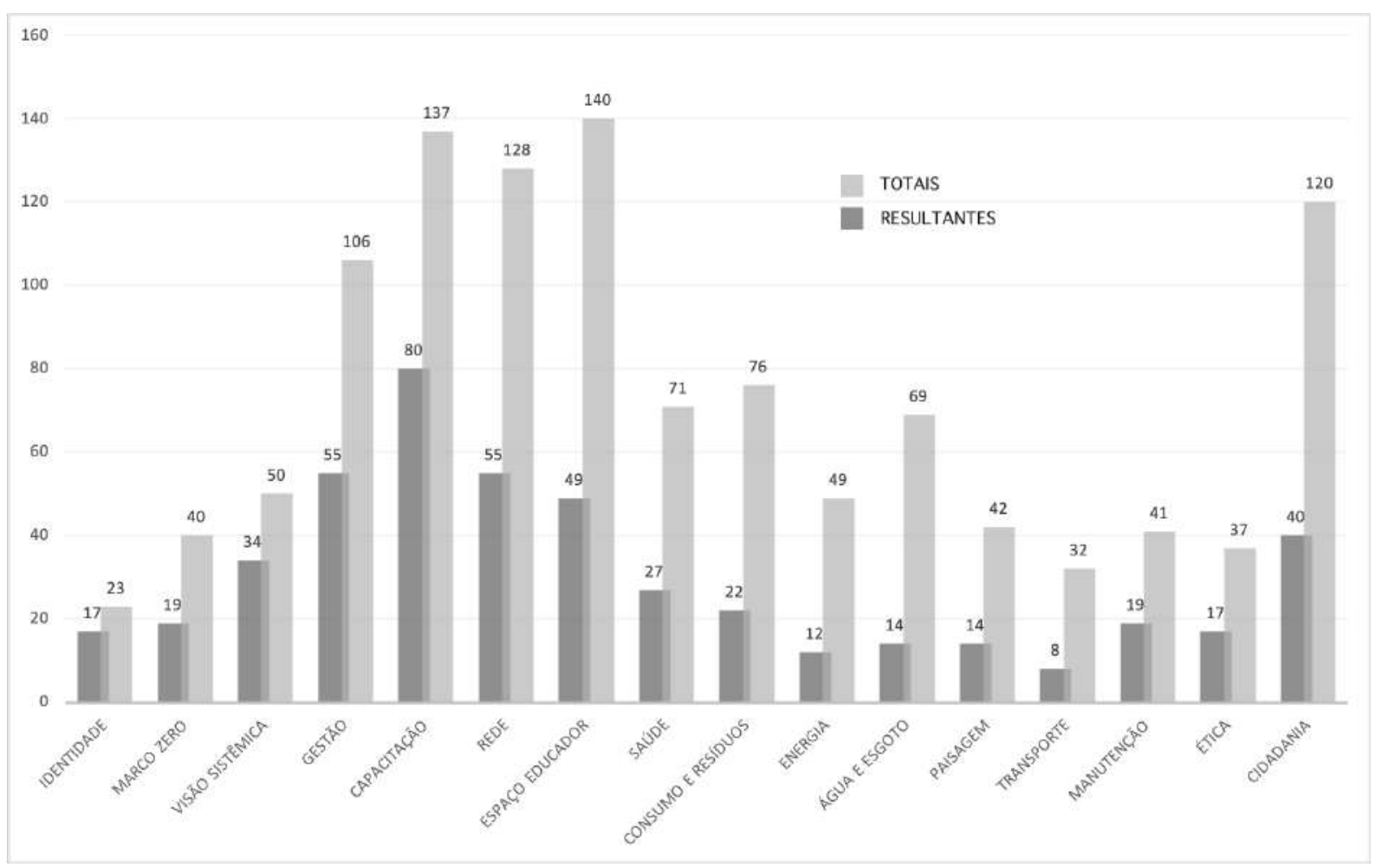

Fonte: Yara Santucci Barreto, 2021

As maiores atenções dos autores pesquisados estão voltadas para como descrever o espaço físico ideal da ES (Espaço Educador); como se capacitar para incorporar transversalmente a EA e a EDS (Capacitação); com quem contar para estruturar esses dois processos anteriores (Rede); quantas são as mudanças de atitude e comportamento da sociedade almejadas e demandadas (Cidadania); como se reinventar e se organizar internamente para otimizar os próprios recursos, distribuir funções e catalisar o processo todo (Gestão). Apresentam-se na faixa média entre 110 e 140 unidades. Nota-se que mesmo após o tratamento dos dados, são essas mesmas as categorias em maior destaque. No entanto, Espaço Educador, Rede e Cidadania apresentaram os maiores índices de supressão dos dados (entre 57\% e 60\%) o que demonstra acima de tudo que há repetição e redundância nesses cenários. Por um lado, isso aponta convergência e unanimidade e por outro, a necessidade de maior foco sobre quais são as reais demandas nessas áreas. Capacitação e Gestão tiveram uma menor supressão (42\% e $48 \%$, respectivamente) dentre essas categorias mais presentes, ainda assim bastante elevadas.

As maiores supressões sofridas, no entanto, entre $70 \%$ e $80 \%$, foram sobre as categorias Água e Esgoto, Consumo e Resíduos, Energia e Transporte. Curiosamente, as três primeiras, são temas que chegam em segundo lugar entre os mais citados, na faixa média entre 50 e 70 unidades, com a abrupta distância de $50 \%$ da faixa média anterior. São assuntos 
emergentes, são discutidos, mas com intensidade e consistência aquém do que necessitam para serem atendidos. Transporte também seria um tema emergente nas escolas, dado o volume de veículos da comunidade e de fornecedores que fazem circular com intensidade diária, mas foi o segundo menos citado com apenas 32 unidades totais, e ainda assim com supressão dos dados em 75\%. Saúde, tema cuja importância dispensa reforçar, também está nessa faixa e também com uma variação de $62 \%$. Paisagem apresentou apenas 42 unidades totais e uma redução de 66\% sobre elas. Manutenção e Ética tiveram supressão de 54\% sobre apenas 41 e 37 unidades totais, respectivamente.

As demais categorias, Identidade, Marco Zero e Visão Sistêmica, referem-se as primeiras etapas e onde o processo todo proposto (Tabela 13) vai construir suas bases - num olhar primeiramente para dentro (Identidade e Marco Zero) e depois progressivamente para fora dos limites da escola (Visão Sistêmica), numa busca que vai do autoconhecimento à consciência abrangente. Demonstram índices mais baixos de supressão: Identidade com 26\% apenas, mas paradoxalmente tem apenas 23 unidades totais, o índice mais baixo de todas as categorias, o que demonstra ser um território pouco citado e quase inexplorado; Marco Zero, mesmo ainda mantendo o olhar para dentro dos limites da comunidade escolar, não incorpora aspectos idiossincráticos como a etapa anterior propõe verificar, mas sim concretos - físicos, estatísticos - e apresentou supressão de $52,5 \%$ sobre 40 unidades de registro totais; e Visão Sistêmica, que mesmo com o olhar ampliado para fora, a categoria teve, no entanto, apenas 50 unidades totais com redução de $32 \%$ após supressões.

Esses índices baixos podem ser melhor comentados a partir do que Meadows (1999) afirma sobre sistemas complexos (Figura 10). Segundo a autora, podem ser de qualquer contexto, então podemos pressupor que a escola pode ser considerada um exemplo de sistema complexo.

Figura 10 - Diagrama de sistemas complexos

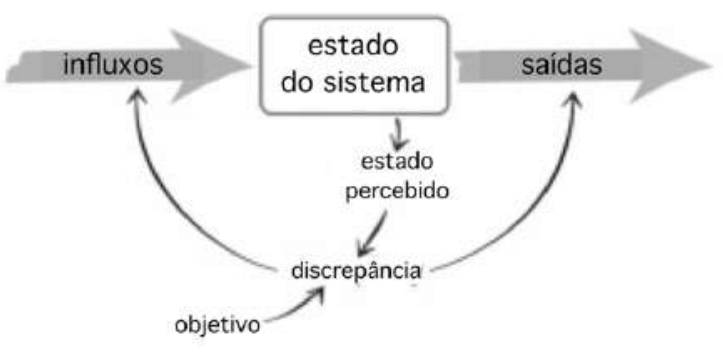

Fonte: MEADOWS, 1999, p. 4, tradução nossa. 
Esse gráfico de Meadows (p. 4) ajuda a compreender a importância dessa primeira etapa do processo proposto, que envolve autoconhecimento e visão sistêmica a partir da escola: o "estado do sistema" seria a realidade de sustentabilidade que a escola apresenta (a se descobrir); o "estado percebido", tudo aquilo que se pode observar em levantamentos pela escola; o "objetivo" seria alcançar o conceito Escola Sustentável; a "discrepância", o que falta para alcançar esse conceito (ou o ao menos o que se acredita faltar); "influxos" seriam ações que somam sustentabilidade e "saídas", procedimentos que subtraem sustentabilidade à escola.

O autoconhecimento toma uma posição central e definitiva para a evolução "negativa" do sistema complexo escolar, como Meadows se refere àqueles que se dirigem mais ao fundo do problema para paradoxalmente solucioná-lo. Compreender em profundidade os mecanismos próprios existentes que interferem na calibragem desse mecanismo complexo, portanto, tornase fundamental.

Pode-se observar que as 5 categorias - Gestão, Capacitação, Rede, Espaço Educador e Cidadania - com pelo menos 50\% de destaque acima das demais, em contraposição as iniciais - Identidade, Marco Zero e Visão Sistêmica - somam ao todo 5,58 vezes mais unidades de registro que este segundo grupo, o que mede a atenção voltada para o meio do processo, sem antes reforçar os alicerces desse movimento; e somam-se ainda 1,66 vezes mais unidades sobre todas as unidades totais somadas das outras Ações (Tabela 13) - Saúde, Consumo e Resíduos, Energia, Água e Esgoto, Paisagem, Transporte, Manutenção. Daí se conclui, respectivamente:

a) muitas das escolas atendidas por programas para implantar a EDS podem ter sua identidade e realidade menos privilegiadas em contraposição aos rumos e metas, preparação e estruturação, já incidentes e em avanço de forma pré-estabelecida por sistemas de autoavaliação existentes. Esses sistemas podem ser válidos e positivos, quando adaptados a cada realidade e ideário escolar, caso contrário, podem levar a consequências como, por exemplo, processos que apresentam progresso parcial ou inicialmente, mas por terem sido estabelecidos verticalmente, sem participação e, portanto, conexão e reverberação com os atores da comunidade escolar (COLE, 2020, p. 1055), tendem a ser descontinuados;

b) ações ambientais efetivas podem estar sendo pouco exploradas ou detalhadas para que sejam efetivadas, ou ao menos acelerem nesse movimento, e ainda demandam atenção.

Dessa metodologia analítica obtém-se os critérios formuladores do conceito Escola Sustentável a seguir apresentado. Vale pontuar neste momento que em resposta à questão principal desta pesquisa, os parâmetros necessários para se alcançar o conceito Escola 
Sustentável puderam ser localizados em bom número, mas seguem evoluindo em função do amadurecimento das pesquisas acerca desse assunto e se adaptando segundo crescentes experimentações em realidades e contextos locais diversos. Quanto ao papel do espaço físico escolar no ensino das ciências ambientais e na sua incorporação ao projeto político-pedagógico, questões complementares deste estudo, são nitidamente movimentos iniciados e em avanço ao redor do mundo, mas demandam mudança estrutural no modelo de ensino e aprendizagem formal enraizado, o que necessita de reverberar em mudanças individuais de todos os atores do cenário escolar, o que nem sempre pode trazer a velocidade que a urgência da transição demanda. Felizmente, os dados mostraram que a capacitação é uma das maiores e mais ativas dedicações neste momento e certamente tende a se expandir por estar sendo atendida com equivalente intensidade pelas parcerias que estruturam esse preparo, como o gráfico da Figura 9 sugere.

\subsection{O CONCEITO ESCOLA SUSTENTÁVEL}

Vale ressaltar neste momento que a definição do conceito Escola Sustentável não visa meramente elencar um plano de necessidades, como por exemplo laboratório de ciências, biblioteca, oficina, estúdio para artes, área para ginástica e esportes, cantina, entre outros ambientes convencionalmente denominados como essenciais para atender funções pedagógicas específicas. O desafio aqui é de extrair, depurar, destilar ainda mais os dados obtidos e obter sentenças que sintetizem com precisão informativa e transmitam com clareza os princípios derivados de todos os temas categorizados que definam o conceito Escola Sustentável.

As contribuições encontradas para essa construção felizmente são vastas, ao que a análise documental e bibliográfica permitiu dimensionar.

As referências utilizadas na estruturação dos Princípios da Escola Sustentável seguem relacionadas:

a) o conceito Escola Sustentável, obtido por meio do método de análise documental e bibliográfica;

b) experiência pregressa vivenciada relatada;

c) embasamento teórico desta pesquisa.

O trabalho de agrupamento e organização dos dados extraídos dos documentos e bibliografias, mais a experiência pregressa em instância escolar - ambos apoiados sobre os conceitos básicos teóricos de sinergia, pensamento abrangente, visão sistêmica, 
autoconhecimento, interdisciplinaridade, ecoefetividade e avaliação de sustentabilidade - são os balizadores para o delineamento desse conceito.

Refletindo sobre o conjunto desenvolvido até aqui, é surpreendente confirmar ao longo do conteúdo pesquisado que o conceito Escola Sustentável adquire sentido somente quando o edifício escolar em seu conjunto:

Torna-se um instrumento interativo de ensino e aprendizagem das ciências ambientais;

II Torna-se incluído ao PPP;

III Reflete a cultura e o ideário da escola.

Sincronicamente, para tanto é preciso que:

I'

O espaço físico escolar se adeque aos princípios ambientais do conceito Escola Sustentável, mas igualmente aos dois outros âmbitos, social e econômico ${ }^{31}$;

II’ A comunidade escolar exercite continuamente a comunicação horizontal;

A comunidade escolar conheça ou construa seu próprio ideário, com bases no III' contexto local - cultural, econômico, social, ambiental e demais dimensões que sejam relevantes caso a caso.

A construção dos preceitos I, II e III acabam por se alinhar simetricamente aos objetivos complementares deste trabalho. As condições I', II' e III' para que eles sejam alcançados se tornam arcabouço para a construção do produto final, o Guia de Princípios da Escola Sustentável.

O conceito Escola Sustentável supõe formar-se numa instância escolar de forma gradual, enquanto vão sendo assimiladas, discutidas e construídas as condições I', II' e III' dentro de seus limites físicos e comunidade, de forma que seus preceitos possam ser aos poucos alcançados, mas como foi visto, numa ordem inversa: III', II', I'.

Sobre as bases dos dados reunidos, delineia-se o conceito Escola Sustentável - com seus respectivos princípios elencados ao longo de uma trajetória encontrada por meio da análise sistemática das literaturas selecionadas, que trafegam indefinidas vezes em múltiplas direções entre os três pilares da sustentabilidade e suas intersecções - no quadro resultante a seguir:

31 Sem os quais não há visão abrangente ou sistêmica e, portanto, sustentabilidade, durabilidade ou estabilidade no sistema. 
Tabela 14 - Princípios do conceito Escola Sustentável

\section{IDENTIDADE}

1. Partilhar da vida diária de toda a comunidade escolar, autoavaliar comportamentos em relação a si mesmo, aos outros e aos ambientes que o cercam.

2. Reconhecer o patrimônio cultural, história e tradições (se indígena, oral, ou outros conhecimentos tradicionais) herdadas no ideário escolar e sua preservação.

3. Avaliar se ecossistemas locais e prioridades ambientais geograficamente específicas interferem na realidade escolar.

4. Reconhecer na escola os seus diferentes aspectos sociais, culturais, ambientais e econômicos interrelacionados; avaliar a preservação e desenvolvimento desse ideário.

5. Buscar conhecer as origens dos problemas já vivenciados pela comunidade escolar ou em curso e identificar suas consequências.

6. Analisar periodicamente o conjunto de prioridades, desafios, oportunidades e eventuais restrições.

7. Avaliar periodicamente os valores sociais presentes na comunidade, os conhecimentos, vocações e habilidades disponíveis na comunidade, as atitudes e competências necessários para a conservação do meio ambiente.

8. Ações para com o fortalecimento do compromisso com a identidade da escola.

\section{MARCO ZERO}

9. Georreferenciamento da escola no mapa do município; examinar ao vivo o terreno da escola e a paisagem do entorno, condições ecológicas, possíveis áreas de risco relativas à erosão, enchentes, secas, vendavais, etc. é um reconhecimento fundamental.

10. Realizar cadastro de biodiversidade na escola e no entorno.

11. Verificar se fornecimento de água potável na escola é regular e em quantidade e qualidade suficientes; ter ciência de onde vem a água consumida pela escola.

12. Calcular o volume do esgoto gerado pela escola e conhecer o seu destino.

13. Ter ciência da origem e tipo da fonte de energia (rede elétrica, vento, água, gerador solar, combustível) que abastece a escola; verificar se fornecimento é regular.

14. Levantamento das relações sociais na comunidade escolar e entre a comunidade escolar; preocupações sociais, econômicas e ambientais urgentes; necessidades sociais, psicológicas e de desenvolvimento de toda a comunidade escolar são reconhecimentos complexos necessários e exercitados.

15. Realizar inventário e divulgação de emissões de gases de efeito estufa e poluentes atmosféricos resultantes das atividades institucionais da escola.

16. Explorar e reconhecer o espaço escolar e analisar as suas condições físicas.

17. Levantamento dos aspectos positivos e áreas potenciais dos espaços escolares.

18. Mapeamento das deficiências no edifício escolar, investigação de suas origens para diagnóstico. 
19. Produzir indicadores físicos e ambientais e acompanhar a cada 2 anos por meio de auditoria autônoma da infraestrutura escolar

\section{VISÃO SISTÊMICA}

20. Conhecer a bacia hidrográfica a que a localidade da escola pertence, cursos de água nos arredores e suas condições quanto à poluição e assoreamento.

21. Conhecer fonte(s) de energia (rede elétrica, vento, água, gerador solar, combustível) que abastece(m) a região ou potenciais locais.

22. Conhecer área(s) de vegetação nativa acessível(is) existente(s) nas proximidades, o bioma ao qual pertence $(\mathrm{m})$ e quais as [suas] características hoje e há 20 (ou mais) anos.

23. Estudar sobre os ecossistemas e recursos naturais locais e verificar seus graus de integridade.

24. Verificar se empresas próximas tratam seus resíduos e como; se a prática de queimar o lixo ainda ocorre na comunidade.

25. Verificar se existem ciclovias perto da escola (se em meio urbano) e se normatizadas.

26. Realizar atividades sensoriais e de integração com a natureza; ampliar o sentido de pertencimento dos seres humanos à natureza; observar a diversidade das espécies de seres vivos são práticas continuadas.

27. Disponibilizar estratégias interdisciplinares no espaço escolar para ampliar o horizonte sustentável e científico da sua comunidade como um todo, cientes do papel significativo que a conscientização, o treinamento e a educação do público têm para alcançar o desenvolvimento sustentável.

28. Estudar programas de gestão ambiental junto aos funcionários para aumentar sua compreensão sobre as questões de sustentabilidade no ambiente construído ou no gerenciamento de serviços.

29. Desenvolver uma compreensão integrada das relações estabelecidas entre os vários grupos sociais locais com o meio natural e com o meio construído.

30. Compreender e abraçar a diversidade entre países e culturas.

31. Estimular a visão complexa, abrangente e a reflexão crítica sobre problemas ambientais para uma educação sistêmica e de cultura compartilhada.

32. Estudar sobre princípios da permacultura e cradle-to-cradle e praticá-los para habitar na Terra sem destruir a vida.

33. Esboçar programa com estrutura holística e perspectiva de um futuro sustentável para a escola e sua comunidade para a criação de ambientes produtivos, sustentáveis e ecológicos e para promover mudança na forma como os alunos percebem e interagem com o ambiente.

\section{GESTÃO}

34. Gestão democrática de governança organizada, inclusiva e participativa do coletivo escolar, lideranças e conselho, nas avaliações, decisões e execuções, com respeito à diversidade, inovação e criatividade.

35. Praticar a convivência de respeito intercultural entre diferenças, a escuta, o diálogo, mediação e arbitragem, a equidade e cooperação.

36. Dedicação, colaboração, gerenciamento de tempo e trabalho em equipe. 
37. Estabelecer um espaço participativo e consensual para planejamento de roteiro de projeto e execução (plano de ação) voltado à sustentabilidade na escola com objetivos e metas viáveis.

38. Estruturar uma coordenação de sustentabilidade - comitês, escritórios ou diretores encarregados - para conectar o currículo, edificação e comunidade escolar ao plano de ação na solução de problemas complexos e discussão das políticas ambientais.

39. Promover modificação holística do currículo escola, objetivos e métodos de ensino e liberdade de escolha de temas transversais ao currículo segundo contextos próprios expostos por meio de uma estrutura organizacional comunitária para trocas mútuas de comunicação

40. Gestão ambiental com dupla função: melhorar a eficiência do edifício e serviços, identificando e corrigindo práticas inadequadas, e envolver os alunos na EDS participativa com o monitoramento e avaliação periódicos do desempenho das ações para atender questões ambientais e de sustentabilidade implementadas nos setores de água, energia, materiais, alimentos, biodiversidade, resíduos ou controle de poluição na escola para que o ambiente de aprendizagem física desempenhe papel central na reforma da cultura operacional da escola.

41. Divulgar, informar e envolver a comunidade escolar sobre iniciativas de sustentabilidade, experiências bem-sucedidas, dificuldades ou oportunidades e criar um código de sustentabilidade da escola a partir das experiências construídas.

42. Sinalizar o compromisso administrativo da instituição com a sustentabilidade e preservação e estimular o conhecimento da sustentabilidade por meio de ferramentas de ensino e mudanças físicas na escola para infundir uma ética de responsabilidade ambiental, fiscal e social em toda a comunidade e gerar engajamento com o desenvolvimento sustentável.

43. Incentivar o desenvolvimento continuado reconhecendo e destacando a comunidade escolar por seus esforços de sustentabilidade.

44. Gestão de pessoas e uso de questionários regulares a funcionários ou outra avaliação para medir seu desempenho como empregadora, a satisfação e o engajamento do funcionário, integrar conhecimentos, aptidões, valores, atitudes e ações.

45. Gestão financeira que administra recursos para atender necessidades atuais com fundos operacionais e para atender projetos futuros, com participação da comunidade escolar no planejamento e na aplicação dos recursos e ampliação da transparência.

46. Plano-diretor prevendo expansão potencial da escola para acomodar as necessidades futuras.

47. Participar de eventos que estimulam inovações e empreendedorismo.

48. Implementar um sistema de gestão ambiental ISO 14001 é padrão internacional

\section{CAPACITAÇÃO}

49. Elaborar o projeto político-pedagógico de forma participativa e submetido a um processo de revisão ou revalidação continuados na construção de conhecimentos interdisciplinares, valores, habilidades, atitudes e competências para a resolução de problemas, pesquisa aplicada, síntese de informação, saber tecnológico, além das habilidades fundamentais de leitura, escrita e cálculo.

50. Auxiliar os alunos a desenvolver os conhecimentos e as habilidades necessárias para serem líderes criativos e autossuficientes num futuro ambiental desafiador e complexo e a cultivar a aprendizagem ao longo da vida por meio de processos dinâmicos ou por mentoria, onde cada indivíduo reconheça suas potencialidades e se tornem embaixadores do desenvolvimento sustentável. 
51. Promover a capacitação ou formação pré-serviço e continuada em EDS de professores e profissionais da área de educação (diretores, coordenadores, monitores) por meio de cursos, workshops e facilitadores que contribuam para o desenvolvimento profissional desses atores.

52. Valorizar os professores que vivenciam uma mudança pessoal em direção à sustentabilidade.

53. Professores recebem tempo e assessoria para planejar a melhor forma de usar os espaços de aprendizagem da escola.

54. Permitir aos professores flexibilidade na escolha de tópicos sobre os quais tenham conhecimento para que tenham domínio sobre o que é ensinado, como é ensinado, o calibre da discussão e a qualidade das atividades de acompanhamento.

55. Estabelecer como tópicos a eco-alfabetização; a permacultura; a conscientização sobre mudanças do clima ou princípios básicos de organização das comunidades ecológicas para incorporá-los na vida diária e na vida da comunidade.

56. Promover uma comunidade de prática $(\mathrm{CoP})$ ou fórum de participação voluntária e informal para professores e profissionais da área de educação discutirem e compartilharem experiências e conhecimento na prática de EDS.

57. A EDS como uma abordagem imperativa e uma estratégia pedagógica holística de metodologia inter, multi e transdisciplinar da educação com campo participativo para o pluralismo de ideias de colaboradores, em novas formas e oportunidades de ensino transversal a todas as disciplinas e na educação especial.

58. Promover pontes entre o saber científico moderno e o saber tradicional enraizado no repertório local.

59. Aprendizagem experiencial, por investigação e educação em valores utilizando o meio ambiente imediato do aluno e do entorno da escola como recurso pedagógico para a educação; perceber demandas sobre o meio ambiente no edifício escolar e comunidade local e explorá-las pedagogicamente de forma transversal às disciplinas junto à gestão ambiental escolar participando da tomada de decisões.

60. Encorajar a aprendizagem baseada em projetos práticos e motivada por uma investigação sobre problemas concretos conecta o currículo da sala de aula ao mundo real do aluno seus próprios interesses: a educação sobre o meio ambiente, para o meio ambiente e no meio ambiente gera impactos mais amplos em sua compreensão da EDS.

61. Ensinar a importância de práticas sustentáveis e soluções ecológicas por meio do exemplo pode envolver alunos, professores e funcionários e fortalecer o currículo escolar servindo como ferramenta pedagógica ativa para a EDS.

62. Salas de aula ao ar livre são mais eficazes no fornecimento de oportunidades de aprendizagem para crianças do ensino fundamental.

63. Capacitar os alunos a se tornarem alunos ativos e participantes ativos em questões locais e globais, desenvolvendo-os em habilidades e criatividade para a solução de problemas à medida que os desafios da sustentabilidade são apresentados.

64. Fomentar a alfabetização ecológica na comunidade escolar como um todo e oferecer programas ambientais na escola, fornecimento de sites interativos, passeios ecológicos, cursos ou workshops em EA curtos, práticas sustentáveis de forma voluntária e gratuita ou palestras sobre os Objetivos de Desenvolvimento Sustentável [ODS].

65. Incentivar alunos e funcionários a adotar ou experimentar práticas e estilos de vida sustentáveis.

66. Fomentar o trabalho voluntário como forma de desenvolver habilidades de liderança e aprofundamento de conhecimentos sobre problemas práticos reais. 
67. Tradução dos princípios de equidade, deferência e democracia no currículo: alunos e adultos ouvem sobre experiências, histórias, documentos, ideias, ferramentas, etc. e respondem ao contexto ambiental; todos aprendem uns com os outros, e todas as formas de conhecimento são ouvidas e respeitadas.

68. Capacitar administradores em habilidades técnicas e competências-chave, como pensamento sistêmico, antecipação, normativa, competência estratégica e interpessoal para a gestão sustentável da escola, e funcionários para preservar, conservar e gerenciar o ambiente e implementar práticas e sistemas sustentáveis.

69. Utilização pedagógica das tecnologias atuais de informação e comunicação para tarefas, pesquisa, avaliação, apresentar trabalhos, desenvolver habilidades e expressão criativa e oferecer acesso à internet e equipamentos eletrônicos possíveis.

\section{REDE}

70. Promover parcerias intersetoriais de partes interessadas em enfrentar os desafios da sustentabilidade num ambiente multicultural e afirmativo reunindo educadores, profissionais de negócios, arquitetos, praticantes de instalações escolares, defensores verdes, profissionais de energia e formuladores de políticas pode ser eficaz em soluções possíveis para os problemas encontrados.

71. Coletivo multidisciplinar de profissionais habilitados convidados, preferencialmente da própria comunidade escolar, é um meio de construir conhecimento, motivar a tomada de ações e melhorar a prática pela experiência compartilhada, além de professores trabalhando juntos para melhorar a educação em suas próprias escolas e diretores locais que se reúnem regularmente para discutir uma gestão eficaz.

72. A escola e seus professores precisam estar continuamente conectados com arquitetos, profissionais de sustentabilidade e outros especialistas externos da indústria e de instituições do terceiro setor para poder explorar tópicos que vão da integração entre design escolar e EDS em seu currículo, à tecnologias emergentes e tendências de programação educacional.

73. Introduzir outras comunidades de profissionais interessados, que podem possibilitar a transferência de conhecimentos e habilidades pertinentes à sustentabilidade; universidades e instituições de terceiro setor têm um papel importante a desempenhar na busca do DS; profissionais de instalações da indústria desenvolveram conhecimentos procedimentais que podem potencialmente beneficiar a implementação de um EMS na escola

74. A EDS é interdisciplinar e deve filtrar todas as disciplinas curriculares e permear todos os aspectos da vida escolar, e dessa forma a colaboração entre professores de diversas disciplinas torna-se uma prática indispensável.

75. Promover co-design: projetar uma solução para a comunidade pela comunidade incentiva os alunos a serem conscientes e reflexivos, diagnosticando e aplicando soluções reais.

76. Buscar suporte especializado para a construção de escola ou a análise sobre a viabilidade de intervenções arquitetônicas sustentáveis em edificações existentes a partir de adequações identificadas como prioritárias.

77. Solicitar avaliação ambiental do solo local e remediação, caso contamidado, atender prioridades ambientais geograficamente específicas e buscar soluções inteligentes para mitigar e melhorar as condições ambientais identificadas.

78. Promover a difusão de tecnologias sociais de adaptação às mudanças climáticas.

79. Priorizar projetos arquitetônicos bioclimáticos, que adotam estratégias passivas para solucionar o conforto térmico e luminoso dos edifícios escolares e corroboram com a busca contínua por soluções para os desafios locais e globais; que reutilizam estruturas existentes, planejam vários usos para as instalações e melhoram o design e a organização do prédio escolar com arranjos espaciais voltados ao bom desempenho de suas 
funções; que adotam sistemas e materiais de construção adequados aos biomas, climas, materiais, paisagens e culturas locais.

80. Espaços educacionais devem ser analisados e desenvolvidos holisticamente para serem atraentes, estimulantes e colaborarem com diversos estilos e oportunidades de aprendizagem para uma cultura sustentável.

81. Buscar recursos de design arquitetônico para espaços de aprendizagem que representem visivelmente a sustentabilidade e gerem conexão com o mundo natural para aproximar a criança da natureza e nela estimular atitudes pró-ambientais.

82. Tornar edificações referências de sustentabilidade socioambiental onde o design dos espaços de aprendizagem permita atividades educativas múltiplas e versáteis e a arquitetura dos espaços de aprendizagem sejam projetados para atender a sustentabilidade e refletir valores pró-ambientais, criando melhores ambientes de aprendizagem ao desempenhar um papel pedagógico na alfabetização ambiental e contribuir para maiores níveis de envolvimento escolar.

83. Projetos para teaching green buildings (TGB) exigem amplos conhecimentos em sustentabilidade para resultar em alta performance de conservação de água e energia e desempenho sustentável de sua construção segundo suas dimensões técnicas e socioculturais.

84. A envoltória do edifício é um componente de projeto que demanda especificações a favor da qualidade do ar interior, conforto e eficiência energética; integrar os espaços interiores e exteriores, maximizar a iluminação natural e minimizar ganho de calor e ofuscamento com elementos de design, como prateleiras de luz e dimensionamento e posicionamento adequados das janelas, orientação e aumento do perímetro do edifício e dispositivos de sombreamento devem ser considerados.

85. Planejar caminhos de ventilação natural segundo zonas de alta e baixa pressão para manter limpa a qualidade do ar de forma passiva e sem geração de ruídos.

86. Solicitar análise da qualidade do ar interno e, se necessário condicionamento do ar, adotar sistemas HVAC \& R que minimizam o impacto direto na redução da camada de ozônio e nas mudanças climáticas.

87. Análise do desempenho acústico, seja nos tetos para controle de ruído e reverberação sonora com materiais absorventes de som adequados, seja para detectar caminhos de ruído como dutos, estruturas e equipamentos ou adjacências.

88. Solicitar cálculos de simulação para maximizar o conforto acústico, térmico e luminoso no projeto arquitetônico de forma passiva com redução do consumo energético.

89. Solicitar desenho arquitetônico para edificações dotadas de conforto térmico prevendo recursos como janelas operáveis, vidros, materiais de qualidade para isolamentos de coberturas ou para radiação do calor para o interior, conforme o clima local.

90. Soluções de eficiência energética em relação ao projeto e construção incluem especificações de equipamentos e especificação de luminárias eficientes para complementar a luz do dia disponível.

91. Solicitar análise do cilco de vida para o projeto do edifício escolar para prever custos da sua construção e operações ao longo da sua vida, demolição, incluindo reciclagem e descarte.

92. Sempre que possível adotar a eco-construção visando o menor impacto de implantação, canteiro e materiais.

93. Avaliar o potencial de energia renovável local e buscar aplicar tecnologias limpas.

94. Priorizar o design para adaptabilidade de pessoas com necessidades educacionais especiais.

95. Apoiar empresas preferencialmente locais comprometidas com a comunidade local, com a sustentabilidade e balizadas em valores sociais e ambientais. 
96. Fomentar e reportar sobre empregos verdes como caminho para a sustentabilidade.

97. Promover o patrimônio cultural e natural locais.

98. Aumentar os canais de comunicação para fortalecer a conexão e o diálogo entre escolas situadas em contextos diferentes e diversos - socioeconômicos, geográficos, culturais para compreender os desafios da sustentabilidade juntos e compartilhar ideias, histórias, problemas, trabalhos, projetos, conhecimentos.

\section{ESPAÇO EDUCADOR}

99. Adotar o espaço físico escolar como uma ferramenta de ensino para promover a apreciação e compreensão do design sustentável e oferecer uma variedade de oportunidades de aprendizagem de livre escolha para temas de sustentabilidade, onde o aprendizado e a ação ambiental acontecem dentro e fora da sala de aula.

100. Ensinar aos alunos a importância da inovação no ambiente construído, seja pelo uso de materiais tradicionalmente adotados pela população local ou técnicas sofisticadas de alta tecnologia.

101. Fornecer ar limpo e fresco que geram conforto térmico, luz natural abundante, baixa distração com ruídos indesejados, qualidade acústica, eficiência energética, segurança pessoal e mínima poluição são diretrizes básicas na ES.

102. Ambientes construídos que integram à paisagem natural e o patrimônio cultural locais são benéficos para a aprendizagem e são especialmente adequados para EDS; lugares onde os alunos vivenciam o desenvolvimento sustentável, espaços em que a energia e a transição ecológica, a emergência de novos estilos de vida, a solidariedade local e internacional se tornem uma realidade.

103. ES apresentam uma concepção de ambiente em sua totalidade, considerando a interdependência sistêmica entre o meio natural e o construído, o socioeconômico, o cultural, a trajetória histórica, o espiritual, sob o enfoque da sustentabilidade e considerando as especificidades territoriais; apresentam boa temperatura, cores adequadas, mobília confortável, visão para fora, liberdade para me mover e permite escolher onde trabalhar, proporcionam um ambiente saudável, confortável, seguro, protegido e estimulante que ensinam práticas sustentáveis.

104. A ES é uma intersecção entre arquitetura e EA e têm muito potencial para transmitir uma ética geral de sustentabilidade pela facilidade de identificação visual de recursos; monitores de feedback de energia, jardins, programas de reciclagem, bicicletários ou painéis fotovoltaicos alguns são exemplos.

105. Parques e espaços exteriores e de lazer da escola são utilizados para aprendizagem como salas de aula; jardim escolar e entorno arborizado e ajardinado para proporcionar melhores condições de aprendizagem e de convívio social.

106. Áreas de lazer e recreação ao ar livre para possibilitar a convivência da comunidade escolar ou mais ampla, com elementos naturais e culturais, propiciar vivências, sensações, interações, onde o ambiente físico de aprendizagem ocorre sob contexto social e individual em processos formal e informal.

107. Centro de sustentabilidade com criação de animais, galinheiro, horta, cultivo de plantas e compostagem é incorporado como espaço educativo.

108. Pavimentação permeável e pisos exteriores de cores claras no lugar de asfalto.

109. Uso das ecotécnicas para apropriação pedagógica.

110. Portas, torneiras e banheiros sem toque.

111. O aproveitamento máximo da luz do dia na edificação escolar tem uma associação positiva e altamente significativa com a melhoria do desempenho do aluno por manter ritmos circadianos de crianças e ciclos de sono saudáveis, além de minimizar o impacto ambiental da edificação por permitir o aquecimento 
radiante passivo, o que demanda a adequada orientação solar do edifício e de suas aberturas e cuidados para não causar desconforto térmico e ofuscamento.

112. A iluminação artificial é complementar, mas de alta eficiência energética.

113. Ambientes pedagógicos da ES apresentam forros acústicos e conforto acústico necessário para isolar ruídos externos e escutar bem o professor e alunos.

114. Sistemas de controle térmico, de iluminação ambiente e sobre as janelas, segundo as preferências dos ocupantes.

115. Vistas abertas para o exterior em corredores ou outros ambientes no edifício são positivas e altamente significativas para o desempenho dos alunos.

116. O caminho natural das correntes de ar nos ambientes promove o equilíbrio térmico quando atendidas as taxas ideais de ventilação e conforto.

117. Os materiais construtivos são preferencialmente naturais e locais, ambientalmente corretos, adaptados às condições climáticas, em conformidade com seu uso construtivo e de fácil aceitação pela comunidade.

118. A sala de aula tem acesso direto a espaços externos, espaço de descanso, espaços para várias possibilidades de aprendizagem: trabalho em grupo colaborativo, trabalho de projeto ou trabalho individual.

119. Espaços dinâmicos de aprendizagem com flexibilidade de layouts para métodos de trabalho individual, em pares e em grupo apoiam a apresentação e o trabalho individual, a aprendizagem em pequenos grupos e dois ou mais professores ensinando em equipe com pequenos grupos de alunos; as cadeiras e mesas são confortáveis, ajustáveis em suas alturas, para que fiquem ergonômicas e podem ser facilmente reorganizados antes ou durante a aula.

120. Uma variedade de espaços bem equipados de diferentes tamanhos conectados que apoiam múltiplos e diversos programas e pedagogias de ensino e aprendizagem: espaço de oficina, estúdio para arte, música ou design, uma cozinha/ espaço de tecnologia alimentar, um espaço de oficina de tecnologias de materiais.

121. Espaço tranquilo para professores socializarem e conversarem com outros funcionários/ professores antes ou depois das aulas.

122. Os telhados verdes operam no gerenciamento do escoamento de águas pluviais e na mediação do ganho de calor solar; regulam a umidade do ar e minimizam ilhas de calor assim como a presença de árvores nativas ou adaptadas, grandes arbustos, treliças com vegetação e a pavimentação permeável.

123. As áreas de alimentação são preferencialmente ao ar livre ou abertas para o exterior.

124. As edificações na ES são acessíveis para pessoas com deficiência, mobilidade comprometida ou necessidades especiais.

125. Adoção preferencialmente de produtos pré-fabricados, pré-montados e modulados, que reduzem perdas e desperdício.

126. O conforto térmico, luminoso, olfativo e a acuidade visual estão equalizados em todos os ambientes de ensino.

127. Tecnologias, modernas ou tradicionais estão integradas ao espaço.

128. Sistema fotovoltaico ou outros sistemas de geração de energia estão presentes.

129. Sistema aparente de aproveitamento de água da chuva, da sua coleta em coberturas ao seu armazenamento em cisterna; calculadora de água da chuva para as crianças medirem a quantidade de água economizada. 
130. Comunicados de mensagens pró-ambientais estão por toda a escola.

\section{SAÚDE}

131. Promover a paz.

132. Promover a saúde por meio da melhoria do ambiente e da qualidade de vida das pessoas e na escola e seu entorno.

133. Ajudar alunos e professores a se manterem saudáveis de corpo, mente e espírito, estimulam passar tempo na natureza ou ar livre e investiga a relação entre a saúde e bem-estar das comunidades locais e o meio ambiente.

134. Oferecer comida saudável, refeições com alimentos de base vegetal de baixo impacto ambiental, alimentos e bebidas à base de vegetais cultivados na horta da escola ou produzidos de forma sustentável e ética promove a segurança alimentar, favorece a preservação da biodiversidade na agricultura de alimentos orgânicos e melhores condições aos trabalhadores agrícolas, solos e hidrovias mais saudáveis.

135. Cultivar pomar de árvores frutíferas que podem complementar as necessidades nutricionais das escolas.

136. Cultivar espiral de ervas e plantas medicinais que podem ser usadas em remédios caseiros em práticas tradicionais de saúde.

137. Garantir a qualidade sanitária dos ambientes, do ar e da água; medidas sanitárias e de hábitos de higiene pessoal para garantia de saúde, segurança e bem-estar coletivo e do ambiente.

138. Facilitar uso dos serviços e instalações de água e saneamento por todos os usuários potenciais do edifício.

139. Eliminar focos de empoçamentos ou água parada em pisos, coberturas ou calhas.

140. Promover o trabalho seguro e socialmente responsável, uso obrigatório de equipamentos de proteção individual (EPI), e prevenir doenças ocupacionais aos funcionários.

141. Os ambientes são livres de cigarro dentro da escola e entorno, por proibição.

142. Garantir a especificação de materiais de acabamento usados em construções e equipamentos não poluentes e/ou com reduzida toxidade. Uso de tintas minerais ecológicas a base de terra crua

143. Os níveis de formaldeído nas ES devem ser mantidos muito baixos ou nulos.

144. Eliminar materiais ou produtos que representam um risco de contaminação.

145. Os materiais de limpeza não devem ser tóxicos, perigosos ou deixar resíduos no ambiente.

146. As áreas verdes são manejadas organicamente, sem o uso de fertilizantes inorgânicos e pesticidas químicos, fungicidas e herbicidas.

147. Reduzir a potencial presença de mofo nas escolas por meio de medidas preventivas de projeto e construção

148. Ventilação é a alternativa eficaz para eliminar CO2 do ar interior gerado pelos ocupantes.

149. Banimento do uso de materiais cuja matéria-prima é o amianto.

150. Uso de lâmpadas isentas de mercúrio ou preferencialmente LED. 
151. A proteção e segurança deve ser garantida em todos os espaços da escola em relação a acidentes ou qualquer tipo de perigo.

\section{CONSUMO E RESÍDUOS}

152. Sistema escolar de gestão de resíduos sólidos e orgânicos prevendo minimização da produção de resíduos, redução de emissões poluentes e do uso de recursos não renováveis, melhoria dos serviços e sistemas de limpeza, distribuição de lixeiras seletivas para segregação dos diversos resíduos, procedimentos de coleta, armazenamento e destinação corretas, compostagem de resíduos orgânicos, apoio à reciclagem de resíduos secos.

153. Compreensão das causas dos hábitos consumistas e agir para a transformação dos sistemas que os sustentam.

154. Não compra se não for necessário.

155. Os 5R: repensar hábitos de consumo; recusar produtos danosos ao meio ambiente ou à saúde; reduzir a geração de lixo; reutilizar sempre que possível; reciclar, transformando em um novo produto.

156. O plano de gerenciamento de resíduos de construção civil e demolição envolve conscientização dos recursos naturais, matérias-primas e emissões poluentes neles agregados e exige segregação e isolamento em área do canteiro de obras dos materiais para reciclagem, reutilização ou descarte correto.

157. Promover a importância da economia circular e da reciclabilidade dos produtos derivados da madeira e incorpora ao projeto de construção materiais recuperados, com conteúdo reciclado, de origem local, de fontes renováveis, madeira certificada por fornecedores comprometidos.

158. Possuir programa de reutilização, recuperação e reciclagem na comunidade escolar de produtos ou materiais, incluindo os de construção, como meio de reduzir o lixo dentro e ao redor da escola.

159. Buscar taxas de participação altas no descarte seletivo consciente e correto, no tratamento de resíduos sólidos por meio da reutilização e reciclagem e da compostagem para os resíduos alimentares, criando uma cultura da prática estética do cuidado com o ambiente e a paisagem, em toda a escola, da sala de aula às operações e administração, da secretaria ao refeitório.

160. Evitar o descarte em aterros sanitários e instalações de incineração de resíduos químicos perigosos à programas de reciclagem; verificar procedimentos junto ao fabricante.

161. O desperdício de todo tipo, incluindo alimentos, onera o ambiente e a escola e deve ser evitado; sobras de alimentos ainda saudáveis podem ser compartilhadas, reaproveitadas ou consumidas posteriormente.

162. A compostagem por minhocário dos resíduos orgânicos vegetais nutrem a horta escolar num ciclo virtuoso com a participação da comunidade.

163. Atender à logística reversa de produtos sempre que possível, que prevê o retorno do resíduo gerado por determinado produto ao seu produtor ou o processamento por empresas recicladoras, especialmente na destinação e descontaminação adequada de lâmpadas, pilhas, baterias e aparelhos eletrônicos.

164. Programa para transformar o óleo de cozinha em sabão, destinado ao uso pela própria escola ou pelas famílias dos estudantes.

165. Reduzir o consumo de materiais em geral e de papel por meio de equipamentos eletrônicos ou outros recursos, reduzir ou eliminar materiais descartáveis ou materiais que tenham embalagens desnecessárias.

166. Comprar papel de escritório somente com conteúdo reciclado e certificado. 
167. Comprar produtos e serviços de comércio justo e preferencialmente de negócios comunitários ou empresas locais que promovem aspectos da sustentabilidade.

168. Compra de produtos, serviços e da agricultura familiar locais para minimizar impactos ambientais e favorecer o pequeno negócio, prevalecendo a produção de alimentos em horta local.

169. Comprar materiais e equipamentos duráveis, eficientes, de baixo consumo energético e de água.

\section{ENERGIA}

170. Gestão eficiente do consumo de energia.

171. Realizar medição do desempenho energético do edifício escolar para controlar e otimizar a sua eficiência energética.

172. Comprar equipamentos com o selo PROCEL (Programa de Conservação de Energia, da Eletrobras), que garante aumento da eficiência energética mantendo baixo o consumo dos sistemas.

173. Adotar sistemas de gerenciamento de energia personalizados como interruptores individualizados.

174. Comprar lâmpadas eficientes de alto rendimento luminoso com baixo consumo energético.

175. Conservar energia nos sistemas de iluminação, ventilação, aquecimento ou refrigeração por meio de dispositivos como termostatos, sensores de movimento ou de presença e fotocélulas.

176. Apoiar o desenvolvimento de sistemas de energia alternativa e produzir a própria energia elétrica a partir de uma ou mais fontes renováveis locais disponíveis, seja solar, eólica, geotérmica, hidrelétrica de baixo impacto, biomassa e biogás.

177. Apoiar a utilização da energia solar ao adotar um fogão solar para preparo de alimentos e em aquecedores solares para produção de água quente em vestiários e cozinhas.

178. Prevalecer a iluminação natural solar sobre a artificial em todos os ambientes da escola.

179. Adotar recursos passivos da arquitetura bioclimática com dispositivos e materiais próprios para sombreamento e isolamento térmico, o que reduz drasticamente as necessidades de aquecimento e refrigeração elevando o desempenho energético do edifício.

\section{ÁGUA E ESGOTO}

180. Não poluir ou desperdiçar água.

181. A rede de água potável é acessível a todos os usuários da escola como direito básico.

182. As instalações de saneamento funcionais são separadas para homens e mulheres.

183. Gestão de águas pluviais prevendo a sua captação, armazenamento e reuso, a sua infiltração natural hidrológica para reduzir contaminação, erosões em canais e sobrecarga na infraestrutura pública.

184. Respeitar e preservar os fluxos naturais das águas pluviais, promovendo a infiltração, minimizando ou substituindo superfícies impermeáveis por pavimentações permeáveis, preservando árvores e espaços verdes que contribuem para a absorção, e recarga de aquíferos.

185. Eliminar o uso de água potável em paisagismo. 
186. Promover uma infraestrutura verde: bioretenção, jardins pluviais, telhados com vegetação, barris de chuva e pavimentos permeáveis.

187. Plantar espécies endêmicas e tolerantes à seca, agrupando as plantas de acordo com suas necessidades de irrigação.

188. Valorizar a água da chuva como um recurso para a redução do consumo de água servida pela rede pública municipal construindo um sistema para coleta nas coberturas, retenção em telhados verdes, armazenamento em cisternas, tratamento para descontaminação, distribuição em tubulação exclusiva e identificada para as descargas de bacias sanitárias e mictórios, irrigação de jardim, de hortas e lavagem de pisos.

189. A água condensada pelo ar-condicionado e coletada pelos seus próprios drenos também pode ser uma fonte alternativa.

190. Gestão integrada de água e esgoto.

191. Adotar dispositivos de economia e eficiência no uso da água, como torneiras de fechamento automático ou por sensor de movimento, válvulas de descarga de baixo fluxo para bacias sanitárias de volume reduzido, válvulas de fechamento automático nos mictórios, chuveiros e metais de baixo fluxo de água, arejador para torneiras e restritores de vazão de água em torneiras de jardim e de lavagem.

192. Usar a água de maneira responsável, sem desperdiçar, reduzir os volumes de águas residuais e garantir o seu tratamento por meio de filtro biológico.

193. Sistemas de saneamento mais inteligentes para esgoto, com redução da demanda de água potável, adotando princípios de decomposição e purificação biológica.

\section{PAISAGEM}

194. Conservar as espécies e seus habitats.

195. Identificar ecossistemas locais, espécies e habitats em estado de vulnerabilidade ou danificados, contribuir para proteger a sua integridade, para restaurá-los e para mantê-los saudáveis e para promover a biodiversidade.

196. Proteger árvores existentes e plantar espécies nativas do bioma local.

197. Contribuir para recuperar o microclima original local e áreas degradadas ou contaminadas ao seu estado natural.

198. Gestão sustentável da paisagem e da biodiversidade.

199. Estruturar as áreas verdes com jardins educacionais, intensificação da arborização, plantio de alimentos, viveiro de plantas, trilhas, mirantes, parques, áreas de lazer e recreação que tornem o terreno verde.

200. Incorporar a sala de aula viva: padrões, microclimas, solos, água, chuvas, flores e vegetais, alimento e nutrição, insetos, répteis, anfíbios, pássaros, animais, ecossitemas, árvores, sol, polinização, vento, ar, atmosfera, bio-indicadores.

201. Prevalecer as plantas nativas/ adaptadas, que requerem irrigação mínima ou nenhuma irrigação e baixa manutenção.

202. Buscar aumentar a área vegetada da escola para além do exigido pela legislação, ainda que por meio de tetos verdes nas coberturas.

203. Adotar a calçada verde. 
204. Adotar serviços ecossistêmicos com vistas à promoção e conservação da biodiversidade dentro da escola.

205. Aproveitar a topografia natural do terreno para drenagens e evitar impactar a paisagem.

206. Prevenir a poluição e erosão com proteção da camada superficial do solo, em circunstâncias de risco, obras civis ou transportes pesados.

\section{TRANSPORTE}

207. Compor sua frota de veículos com baixo consumo e de combustíveis mais limpos.

208. Controlar acesso e minimizar o tamanho do estacionamento.

209. Propor otimizar o uso de estacionamentos vizinhos compartilhados.

210. Estimular o uso de bicicletas e oferecer instalações e dimensionamentos normatizados para bicicletários seguros.

211. Defender o uso de modais de transportes mais sustentáveis para deslocamento diário da comunidade escolar como um todo.

212. Oferecer transporte escolar gratuito, ao menos numa pequena porcentagem, caso esteja dentro da viabilidade da escola.

213. Verificar alternativas possíveis de acordo com a realidade de cada comunidade para mobilidade entre moradia e escola, considerando: transporte público, vans, caronas, compartilhamento de veículos, motocicletas ou scooters, andar de bicicleta, caminhar.

214. Programas de mobilidade sustentável devem prever a proximidade de transportes públicos, faixas de pedestres e ciclofaixas que atendam critérios normativos de segurança, mas também reduzir o deslocamento diário de funcionários, seja por opção de trabalho remoto, seja pelo encorajamento de morar perto da escola.

\section{MANUTENÇÃO}

215. A sustentabilidade depende da eficiência e da qualidade de conservação dos espaços de aprendizagem e da infraestrutura escolar; garantir um ambiente saudável, ventilado e seguro, com foco na supervisão.

216. Garantir um saneamento seguro e manusear a água potável de maneira higiênica.

217. Incluir a manutenção de longo prazo como um componente fundamental do projeto de escolas.

218. Dispor de manuais e diretrizes de design são fornecidos aos profissionais no início do processo de projeto ou de prestação de serviço e estabelecem o cenário previamente.

219. Dispor de manuais de treinamento para informar a comunidade escolar sobre os padrões sustentáveis construídos na edificação e estratégias de economia de energia.

220. O bom desempenho da construção e operações de um edifício escolar ao longo do tempo exige um gerenciamento permanente de equipes de manutenção que cuidarão da conservação das estruturas e dos equipamentos durante todo o seu ciclo de vida.

221. Estabelecer e seguir um programa preventivo e corretivo de comissionamento das operações e manutenções prediais programadas.

222. Diagnósticos de controle sobre os sistemas podem trazer inovação na manutenção dos edifícios escolares. 
223. Durante obras de construções ou reformas, controlar as fontes de poluentes e interromper as vias de contaminação.

224. Eficiência de recursos e poluição mínima.

225. Grades de drenagem nas portas ajudarão a impedir que água da chuva entre nas edificações.

226. O plano de prevenção da poluição em obras civis de construção ou reforma deve prever uma limpeza do edifício ou teste os níveis de contaminantes do ar no edifício antes de sua ocupação pela comunidade escolar a fim de proteger a saúde dos ocupantes dos edifícios e o meio ambiente.

227. Sistema de gerenciamento de energia, aquecimento, captação de água de chuva, de iluminação e arcondicionado centralizados com interfaces simples para serem facilmente monitorados e poder ajustar o consumo de recursos de acordo com o que é colhido.

228. Impedir perda de água e consertar vazamentos em sistemas hidráulicos ou gotejamentos de água em torneiras.

229. Realizar manutenção periódica de equipamentos para uso eficiente da energia.

230. Produtos e sistemas duráveis necessitam de menor manutenção e geram economia.

231. Licitação com a incorporação de exigências de ações de sustentabilidade e responsabilidade social na qualificação das empresas contratadas para serviços ou produtos.

\section{ÉTICA}

232. É de interesse global promover e desenvolver escolas sustentáveis.

233. Refletir criticamente sobre o conjunto de valores defendidos e atitudes praticadas.

234. É fundamental que o currículo da escola em transição para a sustentabilidade estabeleça continuamente a interação entre o que se aprende e o que se pratica, alinhando discurso e atitude, para que a escola seja congruente com a sustentabilidade que ensina e forme cidadãos que apliquem os aprendizados recebidos à vida diária.

235. O funcionamento de um campus escolar reflete a filosofia da educação que impulsiona as políticas e práticas educacionais.

236. A sustentabilidade se constrói na concretude das ações, no compromisso com a ética, o humano e o planeta, por meio de ações permanentes.

237. Ter consciência ética, respeito e sensibilidade sobre todas as formas de vida do planeta.

238. Respeitar os pedestres com calçadas suficientemente amplas, desimpedidas, com rampas acessíveis, para mobilidade e acessibilidade segura e confortável.

239. Infraestrutura adaptada para a mobilidade e acessibilidade de alunos com diferentes tipos de deficiência segundo as normas vigentes.

240. Uso exclusivo de madeira legal adquirida em fornecedores cadastrados para construções novas, reformas ou ampliações e na aquisição de mobiliário.

241. Buscar a especificação correta de materiais e componentes em conformidade as normas técnicas ou certificadas. 
242. Seguir as regras e normas para que os gerenciamentos de resíduos e transporte funcionem.

243. Remunerar de forma justa e cuidar da saúde dos trabalhadores.

244. A ES se posiciona contrária a qualquer forma de suborno.

245. Professores com conhecimento de EDS influenciem os alunos, e alunos com conhecimentos de EDS poderão influenciar as atitudes e alterar comportamentos.

246. O compromisso pessoal e os objetivos de ensino dos professores são fatores destacados como importantes para a EDS.

247. O processo de EDS começa com o conhecimento do conteúdo EDS, práticas de EDS, atitudes a partir da EDS e termina com a construção de comportamento resultante da assimilação da EDS.

248. Promover práticas sustentáveis que conservem os recursos naturais e limitem as emissões de gases de efeito estufa.

249. Edifícios escolares com elementos naturais interiores, motivos da natureza, luz do dia, entre outros diversos componentes de mensagem visível da sustentabilidade podem ser uma oportunidade para a mudança de comportamento de seus ocupantes e melhorar o engajamento com relação por exemplo ao consumo de energia e água.

\section{CIDADANIA}

250. Defender a qualidade ambiental como um valor inseparável do exercício da cidadania em campanhas de divulgação da sustentabilidade na instituição e com a participação em políticas públicas que abordem a sustentabilidade.

251. Transmitir a capacidade de transformar o conhecimento fundamental em ação consciente e irradiar soluções sustentáveis para a comunidade e além.

252. Promover uma consciência crítica e a interpenetração entre escola, comunidade e o meio ambiente com a abertura da escola para a vida do bairro, os seus problemas e a sua comunidade mais ampla.

253. Promover a conectividade da comunidade a diversos serviços básicos ao redor ou proximidades da escola.

254. Diretrizes de sustentabilidade têm influenciado o cuidado dos alunos pelos outros, pelo meio ambiente e por toda a comunidade.

255. Demonstrar que uma mudança na educação regular para processos ascendentes que envolvem discurso, reflexão crítica e ação são meios viáveis de abordar os desafios de sustentabilidade no nível da comunidade e de incentivar abordagens de aprendizagem social, colaborativa e multidisciplinar.

256. Participar interessados na formulação e execução de pesquisas relacionadas à problemáticas ambientais.

257. Comemorar datas e realizar campanhas de conscientização incentivando a divulgação de ações pela sustentabilidade.

258. Compartilhar sobre ações por diferentes meios de comunicação, como escrever blogs e posts em redes sociais, criar vídeos, organizar comícios e demonstrações, exposições, peças de rua e flash mobs ou escrever para as autoridades.

259. Estimular o comportamento dos alunos em relação ao meio ambiente, preparando-os para serem indivíduos responsáveis, éticos, com pensamento crítico e cidadania ativa em prol da sustentabilidade. 
260. Promover atitudes pró-ambientais nos pais, uma vez que é preciso uma mudança social generalizada para lidar com as questões de sustentabilidade.

261. Edifícios verdes de ensino podem desempenhar um papel na mudança de comportamento em prol do comprometimento com o meio ambiente a partir do conhecimento e engajamento em sustentabilidade que promovem especialmente por meio de disposições afetivas que inspiram em seus ocupantes.

262. Praticar reconhecimento, valorização e o respeito à pluralidade e à diversidade individual biológica, social, cultural, etnorracial, de gênero.

263. Defender uma sociedade de direitos, ambientalmente justa, inclusiva e sustentável.

264. Praticar e promover valores sociais de solidariedade, igualdade de gêneros, respeito aos direitos humanos, equidade social, cidadania, interação entre as culturas.

265. Protesta contra enfoques etnocêntricos, raciais ou sexistas, contra o vandalismo, a discriminação, a violência e preconceitos.

266. Pratica e desenvolve habilidades essenciais da sustentabilidade: cooperação, interagir com diferenças, mediação e resolução de conflitos.

267. Dedicar esforço para compreender e promover o diálogo local e global.

268. Experimentar senso de compaixão e solidariedade que os serviços comunitários durante e após desastres ajudam a desenvolver são fundamentais para alcançar a sustentabilidade.

269. Compartilhar exemplos positivos de redução das desigualdades e tempo e outros recursos com comunidades ou pessoas em desvantagem ou marginalizadas.

270. Definir posição contrária o estigma associado aos transtornos mentais.

271. Tradução no currículo escolar de todos os valores sociais como diversidade e equidade dos alunos e dos funcionários, cultura inclusiva e acolhedora na escola, remuneração de funcionários e benefícios suficientes para atender às suas necessidades básicas.

272. Adquirir autonomia na busca do saber: autocapacitação.

273. Praticar o engajamento individual e coletivo na transformação local e global por meio de articulações de ações de educação ambiental nas escolas e compartilhamento de responsabilidades pela mobilização das comunidades como cidadão global ativo.

274. Investigar e relatar exemplos que ajudam a erradicar a pobreza em vários níveis, de local a internacional.

275. Dar suporte a esforços globais para atender aos ODS.

276. Formar uma cidadania ativa em favor da sustentabilidade por meio de ações como a de plantio de árvores que contribuem para a economia, segurança alimentar e proteção das funções da paisagem ou a de crianças participando de limpezas de rios ou praias, ou da estabilização da erosão do solo.

277. Favorecer parcerias com cooperativas e associações de catadores de lixo no município para a manipulação e compra local dos resíduos gerados pela escola.

278. Colaborar com autoridades, empresas e outras partes interessadas na sustentabiliadde.

279. Colaborar com alunos de outras escolas locais, de outras regiões ou com alunos em outros países.

280. Facilitar e apoiar a resiliência da economia solidária local e justa. 
281. Apoiar o uso de materiais e produtos de preferência que possam ser adquiridos no comércio local.

282. Reduzir ou ser seletivo em relação aos alimentos importados e estimular o consumo de alimentos locais.

Fonte: Yara Santucci Barreto, 2021

O repertório de contextualizações pedagógicas que desse quadro se depreende pode demonstrar o vigor e potencial educacional que a EDS por meio da Escola Sustentável pode alcançar e seria redundante mencionar práticas pedagógicas dentre os princípios, pois todos os temas são passíveis de ricas abordagens educacionais e de transversalidade.

Entende-se por base que o sistema inteiro apresentado se integra ao conteúdo pedagógico e passa a ter o papel interativo e facilitador às disciplinas pretendido nesta pesquisa. A Escola Sustentável, como muitos dos autores analisados declamam em uníssono, traz uma mudança de paradigma no universo escolar e no modelo de ensino: o de abrir as portas das salas de aula, de ampliar a visão e compreensão do seu sistema como um todo, apropriar-se de todos os espaços da escola para fins de ensino e aprendizagem e proporcionar a esse processo a liberdade criativa, intelectual, emocional e física; levantar o olhar para além da comunidade e cenário próprio escolar e exercitar a visão abrangente, o pensamento holístico.

\subsection{GUIA DE PRINCÍPIOS DA ESCOLA SUSTENTÁVEL}

Como objetivo final alcançado, o Guia de Princípios da Escola Sustentável, produto final deste mestrado profissional, pretende conduzir a comunidade escolar e seus gestores a um exercício orientado e sistêmico de autoconhecimento, percepção local e ampliada, para a autoavaliação das demandas e potenciais existentes na escola e sua comunidade e balizar-se ao buscar adequações e alinhamentos que nela se façam necessárias, de forma que as ações que desse instrumento se revertam, favoreçam a transição das escolas para o conceito Escola Sustentável.

Tal exercício propõe também identificar a identidade da escola, fortalecendo o seu ideário e também autonomia. Ao se percorrer os numerosos tópicos desse instrumento, é igualmente esperada a contribuição à transversalidade pedagógica das ciências ambientais aplicadas ao contexto físico escolar e à horizontalidade entre o espaço escolar sustentável e o projeto político-pedagógico (PPP) em escolas de educação básica, ao conjugar elementos pertinentes à sustentabilidade e comuns nessas duas instâncias. 
O guia segue o modelo de universalidade e foi feito para ser utilizado por qualquer escola em qualquer contexto e pressupõe o mesmo "espírito de solidariedade global" da atual referência em agenda global, os ODS da Agenda 2030 (ONU, 2015, p. 2).

A proposta deste guia é a de que os próprios gestores e comunidade escolar assumam o papel de autoavaliadores contínuos e permanentes dos princípios do conceito Escola Sustentável colhidos aqui ao redor do mundo. Não haverá um pesquisador ou figura externa a avaliar de fora para dentro, como é comumente em pesquisa. Este instrumento pretende estimular gestores e comunidade escolar a serem autônomos e a exercitarem o autoconhecimento e a autoavaliação interna de forma colaborativa, conjunta, continuada e sistêmica. Outro aspecto refere-se à profundidade por este instrumento proporcionada, necessária para alcançar resultados concretos e permanentes.

A comunidade escolar pode inserir-se no "princípio de diversificação interna ou intragrupo", critério de orientação de pesquisas qualitativas que Pires (2008, p. 196) descreve como um modelo onde "pretende-se apresentar um 'retrato global', mas somente no interior de um grupo restrito e homogêneo de indivíduos." Com isso, quer dizer que a análise deve ocorrer somente entre os membros daquela comunidade ou "grupo", mas em seguida "deve se ater à diversificação interna de seu grupo" e escolher representantes de diferentes setores, classes sociais, idades, etc.

Com relação à composição do grupo ou "intragrupo" onde cada ator é, segundo Poupart (2008, p. 222),

\footnotetext{
[...] informante-chave, capaz precisamente de 'informar' não só sobre as suas próprias práticas e as suas próprias maneiras de pensar, mas também - na medida em que ele é considerado 'representativo' de seu grupo ou de uma fração dele sobre os diversos componentes de suas sociedades e sobre seus diferentes meios de pertencimento. (POUPART, 2008).
}

O trabalho de analisar e discutir as questões, uma a uma e definir suas respostas, seria realizado em grupo composto por um ou mais representantes de quantas mais forem as categorias de atores constantes na instância escolar, como a Figura 11 exemplifica, e não apenas por parte delas ou atores individuais. 
Figura 11 - Modelo equânime de composição de grupo multidisciplinar em instância escolar

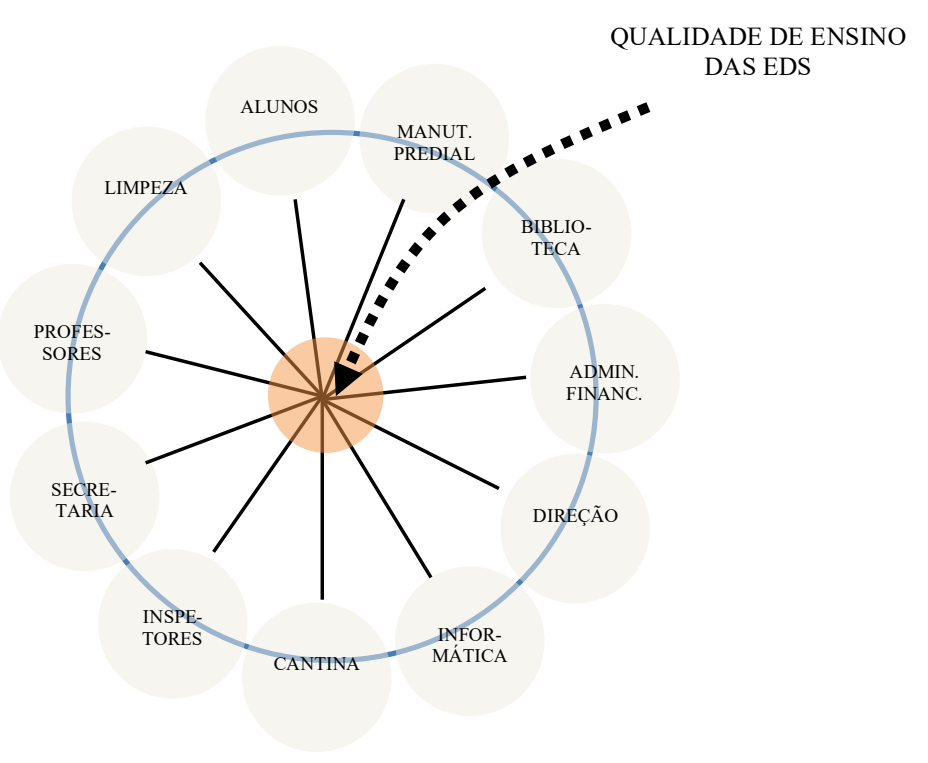

Fonte: Yara Santucci Barreto, 2019

Análises subjetivas próprias e compartilhadas, lembra-nos Flick (2004), "proporcionam um levantamento real", de forma que entre os membros da comunidade escolar torna-se fundamental e indispensável o exercício democrático e equânime de opiniões, para alcançar um resultado preciso e com maior garantia de sucesso na sua implantação.

Lembrando Freire ${ }^{32}$ (1974, p. 93, apud BRASIL, 2012b, p.18), “neste lugar de encontro não há ignorantes absolutos, nem sábios absolutos: há homens que, em comunhão, buscam saber mais", a participação dialógica conjunta de todos os atores indistintamente reconhecidos como imprescindíveis em seus papéis perante as metas de ensino pedagógico e bom funcionamento do espaço escolar, sem distinção de nível hierárquico, cultural, econômico ou social será portanto condição, para que a autoavaliação se torne um trabalho amplo, compartilhado, cooperado, participativo e com um resultado eficiente e seguro, tendo como objetivo comum e último a ser perseguido a transição das escolas para o conceito Escola Sustentável.

[...] toda pessoa tem um poder de influência sobre o contexto de que faz parte [...]. No entanto, a falta de consciência dessa interferência resulta em uma falta de consciência do poder de participação que tem [...], o que não traz benefícios para nenhuma parte. (LÜCK, 2011, p. 19)

Trabalhar em um clima participativo provoca a melhoria do comportamento, que consequentemente reduz a resistência a mudanças, ao mesmo tempo em que aumenta a motivação [...], por meio da satisfação de expectativas mais altas. (ibid, p. 21) 
Cada comunidade escolar com sua própria conjuntura cultural, material e dinâmica terá uma composição própria, mas deverá exercitar os princípios democráticos da imparcialidade e horizontalidade aqui ressaltados, proporcionando sempre empoderamento e representatividade à todas as partes que a integram. Lideranças serão imprescindíveis para o engajamento participativo da comunidade, como Lück também ressalta:

\footnotetext{
Chamamos de liderança a um conjunto de fatores associados como, por exemplo, a dedicação, a visão, os valores, o entusiasmo, a competência e a integridade expressos por uma pessoa, que inspira os outros a trabalharem conjuntamente para atingirem objetivos e metas coletivos. (ibid., p. 33)
}

Pais poderão também compor o grupo, especialmente se forem atuantes na escola e assim tenham repertório com maior validade para participar. Cabe à cada grupo formado definir o ritmo, modelo e dinâmica dos encontros para tais discussões, com ou sem intervalos, sendo o mais importante prolongar a experiência e com isso potencializar o desdobramento do autoconhecimento.

\subsection{CONSIDERAÇÕES FINAIS}

Vista como questão emergencial, a pulverização da EDS pode ficar sujeita a ações precipitadas, se estas não envolverem a devida capacitação das partes que pretendem executálas. Sendo a instância escolar, privada ou pública, uma unidade autônoma ou semiautônoma, essa capacitação pode ser entendida como um compromisso assumido ou ser negligenciada, o que dependerá especialmente do perfil de seus gestores e comunidade. Isso pode tornar o processo frágil ou incipiente, por haver ainda altos riscos de improcedências nas condutas desses atores, que já enfrentam problemas sociais crônicos recorrentes e acumulados.

Promover a percepção global de seu meio ambiente à cada ator da comunidade escolar em prol da construção de um senso crítico construtivo e criativo, é um esforço coletivo, mas também um trabalho de liderança importante, que pode motivar o empoderamento construtivo e o pertencimento, os quais são assuntos excessivamente carentes à sociedade atual.

Sobre o significado do termo adequação, adotado amplamente neste trabalho e em textos consultados para referir-se a intervenções físicas no espaço escolar para alinhamento aos preceitos da sustentabilidade, há de se atentar que tais execuções envolvem complexidades e dificuldades diversas em função das amplas diversidades circunstanciais técnicas, humanas, climáticas, culturais, econômicas, dentre outras possíveis variáveis. Portanto, é essencial cuidar para que o termo seja adotado pela escola e atores de sua comunidade sem eximir-se de uma 
aferição preliminar caso a caso de eventuais alertas sobre a viabilidade e executabilidade de tais adequações que se intencione.

Para tanto, há uma menção clara em alguns programas internacionais dedicados ao alinhamento das escolas à sustentabilidade sobre a participação multidisciplinar de profissionais que somem conhecimentos, que assumem responsabilidades técnicas perante seus respectivos conselhos sobre as adequações previstas, como procedimento correto para se obter parâmetros seguros às intervenções físicas no espaço escolar ou de outros tipos. Sem tal consciência, escolas podem escolher a arbitrariedade, já que as dificuldades financeiras e de gestão das escolas públicas brasileiras, por exemplo, nos levam a considerar que muitas delas acabariam invariavelmente impelidas a economizar custeios adicionais com contratações para projetos e planejamentos e buscariam suas próprias alternativas práticas.

No caso de intervenções físicas, há diversos riscos implicados nesse procedimento: 1) acidentes decorrentes de eventual inviabilidade técnica ou estrutural; 2) execução irregular ou ineficaz, por eventual inabilidade de mão-de-obra, técnica ou materiais inadequados ou sem supervisão de profissional técnico responsável competente; 3) conflitos de uso e conservação decorrentes de novas demandas geradas; 4) uso indevido ou desperdício de verbas (públicas ou privadas) e de materiais mal-empregados; 5) dissociação cultural ou idiossincrática do ideário escolar em cada caso.

Talvez por algumas dessas inadequações terem sido localizadas por Bianchi (2016) em lacunas na configuração do único e não-consolidado programa brasileiro para escolas sustentáveis, o PNES, é que o conceito Escola Sustentável tenha sido prematuramente julgado uma "utopia" aos olhos de seus próprios autores, como as entrevistas de sua pesquisa a estes relatam:

\begin{abstract}
A partir das falas dos entrevistados, identifiquei que as escolas sustentáveis representam um horizonte utópico, que busca desenvolver no espaço escolar uma nova cultura, fundada na noção multidimensional de sustentabilidade (ambiental, social, econômica, cultural ética, estética, espiritual), com base em intensa participação, no sentido de formar cidadãos e cidadãs politicamente engajados na transição para uma nova sociedade (BIANCHI, 2016).
\end{abstract}

Baseada em experiência pregressa relatada e nos dados colhidos por esta pesquisa, seria possível e caberia aqui argumentar acerca dessa controversa impressão inalcançável da Escola Sustentável em relação ao progresso desse conceito evidenciado em vários lugares do mundo atual, que procedimentos técnicos devidamente coordenados por profissionais capacitados e qualificados, como foi colocado ao final do relato de experiência, mais a presença e participação responsável da comunidade escolar e seus gestores em todo o processo, são 
essenciais para efetivar a implantação da sustentabilidade nas escolas. Responsabilidades compartilhadas, a transição ganha impulso - o profissional responde tecnicamente e a comunidade escolar, beneficiária ou proprietária, responde pelo uso e conservação sobre o que foi executado no espaço físico escolar. Porém, “exime-se da responsabilidade técnica a empresa ou profissional quando o seu parecer técnico não for observado pelo proprietário ou usuários da edificação", conforme alerta a NBR 5674, o que aponta para uma fragilidade que essa questão pode trazer, caso a comunidade escolar e seus gestores não se tornarem plenamente conscientes de seu papel e o assumirem nesse empreendimento compartilhado. (ABNT, 1999, p. 3). Os passos a serem percorridos para alcançar a adequação ambiental do espaço escolar, como as análises documentais e bibliográficas puderam demonstrar, em consonância à experiência pregressa relatada, são trilhados por meio de planejamento de ações graduais programadas que partem de um mapeamento diagnóstico inicial, ou "marco zero", como foi chamado o "levantamento inicial sobre as condições de infraestrutura e de consumo da escola", desenvolvido a partir da implantação da COM-Vida na escola, para "dar início às atividades voltadas para a transformação da escola em um espaço educador sustentável.” (BRASIL, 2012b, p. 34) - cujo nome foi então adotado em uma das categorias resultantes da análise documental e bibliográfica realizada por esta pesquisa. Na escola em São Paulo, conforme relatado, a administração das primeiras forças-tarefas e ações pontuais emergenciais, mais a demonstração dos procedimentos dentro de um ritmo ajustado em comum acordo no cronograma escolar, prepararam o setor administrativo e técnico para as etapas subsequentes.

O conceito Escola Sustentável pode tornar-se uma realidade de transformação continuada se dentro de uma estrutura em rede - que traga a mínima estabilidade necessária para esse movimento se tornar factível e permanecer em avanço. A própria proposta da COMVida considerava "fazer parcerias com outras escolas, entidades da sociedade civil, poder público - como prefeitura, secretarias (especialmente de educação e de meio ambiente) estabelecimentos comerciais, empresas, indústiras.” (BRASIL, 2012a, p. 28).

Nota-se ao redor do mundo um movimento amplo que agrega instituições, governos, grupos sociais, organizações não governamentais e empresas, que converge para catalisar a transição das escolhas e condutas humanas de maneira consciente e equalizada perante o seu meio ambiente, a sociedade e a economia. Há novos paradigmas se conformando aos poucos e avançando, embora a resistência ainda seja uma realidade em muitos círculos.

Tal rede deve incluir não apenas atores internos, mas contribuições de atores externos, tais como arquitetos, urbanistas, profissionais da área de meio ambiente, ou outros, mas pode 
também incluir stakeholders por parte da administração pública, instituições e também setor empresarial. A construção de parcerias governamentais e institucionais e mesmo empresariais pode trazer ainda mais força e estabilidade para o círculo virtuoso sustentável nas escolas atores estes que podem ser conjugados conforme cada caso, a partir do esforço conjunto de toda a comunidade escolar em buscar articular tais apoios e parcerias, para se alcançar resultados concretos e duráveis.

O sucesso do neozelandês Enviroschools Programme, por exemplo, adotado por $1.354^{33}$ das $2.500^{34}$ escolas do país, que conta com a parceria e apoio do ministério do meio ambiente do governo da Nova Zelândia e com uma vasta rede de parceiros institucionais e empresariais, confirma a importância de poder contar com todos esses atores:

\section{Através do empenho de tantos, temos agora uma rede de apoio madura com uma gama de parceiros, patrocinadores e colaboradores desempenhando diferentes funções e apoiando vários aspectos da Enviroschools." (ENVIROSCHOOLS. Enviroschools Programme, 2021, tradução nossa. Disponível em: $<$ https://enviroschools.org.nz/about-us/our-partners/> Acesso em 11 de jul. de 2021).}

Entretanto, avaliações autônomas da sustentabilidade nos espaços escolares, ou autoavaliações, como é o caso dos formulários OECD School User Survey (OECD, 2018) e LEED for Schools (USGBC, 2016), vêm sendo disponibilizados gratuitamente pela internet, buscando certamente alavancar o movimento de adequação dos espaços escolares ao conceito da sustentabilidade. O primeiro é voltado mais essencialmente a questões subjetivas de como o espaço físico escolar é aproveitado e aspectos acerca de recursos disponíveis, conforto e segurança. O segundo, que traz uma visão esmiuçada de diversos aspectos técnicos incluindo tópicos como entorno, transportes, poluição, terreno, materiais, qualidade do ar interior, entre outros, se baseia em normativas e traços culturais do seu país de origem (EUA), mas se adaptado, pode ser aproveitado noutras localidades. Buscam ser universais, embora tragam visões específicas. Demandam, como todo formulário, uma postura disciplinada de autoavaliação, mas também a complementaridade externa técnica profissional e institucional, especialmente no segundo caso.

O Guia de Princípios da Escola Sustentável aqui proposto, por reunir múltiplas contribuições desses e de diversos outros conteúdos analisados, amplia o instrumento para uma ótica e ação diversificada e abrangente de forma a eliminar lacunas que uma ou outra literatura

33 https://enviroschools.org.nz/your-region/ 
possa apresentar, com o objetivo de atender de forma o mais completa possível à sustentabilidade. 


\section{CONCLUSÕES}

O principal objetivo deste trabalho - definir um contorno global do conceito Escola Sustentável e elencar seus princípios universais por meio do Guia de Princípios da Escola Sustentável, produto final deste mestrado profissional - foi alcançado a partir de contribuições globais colhidas em análises documental e bibliográfica, refinadas com a análise de conteúdo, conforme aplicações demonstradas. Considero tal contorno obtido um resultado fiel do estado da arte desse conceito no momento atual. O conceito não deverá, obviamente, se encerrar e sim permitir absorver alterações que decorram de futuras mudanças de qualquer classe, sejam, por exemplo, climáticas, ambientais, urbanas, tecnológicas, culturais ou econômicas. Equitativamente, em resposta à questão principal desta pesquisa, os parâmetros necessários para se alcançar o conceito Escola Sustentável puderam ser localizados e apresentados em grande número e seguem evoluindo em função do amadurecimento das pesquisas ainda em avanço acerca desse assunto e se adaptando segundo crescentes experimentações em realidades e contextos locais diversos.

Os três objetivos específicos desta pesquisa foram identificados no decorrer dos estudos como parte intrínseca do processo de construção da sustentabilidade na escola e dessa forma se tornam etapas indispensáveis a serem atendidas para a evolução do processo. Curiosamente, se desencadeiam em ordem inversa ao apresentado introdutoriamente: o objetivo de preservar, fortalecer ou mesmo construir o ideário escolar e conhecer o perfil etnográfico e idiossincrático de sua comunidade torna-se primeiro passo no roteiro, o do autoconhecimento; subsequentemente, o exercício da observação do meio ambiente imediato, com ampliação gradual para o circundante como meio de contextualizações pedagógicas, atende ao segundo objetivo específico ao integrar o espaço físico escolar ao PPP; e, finalmente, adotar o espaço educador da escola sustentável, ou em processo de alinhamento com a sustentabilidade, e o vasto repertório de ações relacionadas à contextualização das ciências ambientais que ele envolve, vem alcançar de forma continuada e permanente o terceiro objetivo específico. Em resposta às duas questões complementares deste estudo, quanto ao papel do espaço físico escolar no ensino das ciências ambientais e aos esforços para a sua incorporação ao PPP, são nitidamente movimentos iniciados e em avanço ao redor do mundo, mas demandam mudança estrutural no modelo de ensino e aprendizagem formal enraizado, o que necessita de reverberar em mudanças individuais de todos os atores do cenário escolar, o que o produto final deste mestrado profissional, o Guia de Princípios da Escola Sustentável, propõe estimular. 
Os desastres ambientais de grandes proporções citados na revisão de literatura encontram correspondência com pequenos múltiplos impactos em cenários de menor escala, como os das escolas. Questões sociais e econômicas igualmente podem ser reproduzidas dentro de suas comunidades. Os desvios da sociedade são diversos e já somados. No microcosmo escolar essa também pode ser uma realidade, o que em maior ou menor proporção demandará tempo, empenho, comprometimento e determinação para revertê-la a um percurso onde o discurso e ação são coerentes quanto ao conceito Escola Sustentável. O edifício escolar revela muito do que é preciso corrigir na conduta da gestão escolar e o instrumento aqui oferecido pretende trazer motivação esse processo.

Em todas as literaturas analisadas e estudadas não foi encontrado um instrumento sistêmico como o presente guia desenvolvido. O produto neste oferecido, vem elencar 282 princípios balizadores acerca de todos os aspectos contemplados até hoje pelos autores atentos há décadas ao tema Escolas Sustentáveis, abrangentes o bastante para assegurar uma transição real para a EDS. Trata-se de um repertório reunido de forma inédita e que vem contribuir para o alinhamento das escolas às agendas internacionais já criadas.

O que garante o interesse e o envolvimento das escolas em um sistema de autoavaliação e reflexão como o que este trabalho propõe?

Já que não temos no momento um programa nacional próprio, nada garantirá essa mobilização, além da profunda compreensão e conscientização de que implantar a sustentabilidade dentro e fora da escola se tornou "um imperativo moral e ético" (p. 72), como aponta a Declaração de Thessaloniki desde 1997 (BRASIL, 1998, p. 71-74), além de emergente, diante do cenário sistêmico crítico atingido a partir das ações antrópicas - fontes não renováveis reduzidas, biodiversidade prejudicada, poluição atmosférica e das águas - por uma população que em breve alcançará 8 bilhões de habitantes ${ }^{35}$.

Restabelecer um programa como o PNES e reativar políticas públicas já experimentadas, como a COM-Vida, poderia enquadrar e acelerar o movimento em direção à EDS nos domínios brasileiros.

O conceito Escola Sustentável uma vez em processo de implantação somente colherá benefícios, não apenas à instância escolar - enquanto instituição pedagógica de ensino ou patrimônio físico e cultural a ser conservado - mas essencialmente à comunidade que ali conforma e à sociedade que ajuda a formar, enquanto incubabora de cidadãos responsáveis, 
críticos, inclusivos e pró-ativos - o que consequentemente polinizará a intenção genuína e o encorajamento em mover esforços nessa direção.

Espera-se que o leitor possa ser contagiado com o conteúdo apresentado como um todo e que a partir desse conhecimento adquirido se engaje com sua comunidade escolar para nela fomentar um processo progressivo ao longo de suas etapas graduais de autoconhecimento, ampliação da visão, organização, preparação, estruturação, ação e aquisição de valores, segundo o roteiro encontrado e apresentado - fazendo pleno uso do instrumento produzido por este estudo para localizar potenciais e demandas em sustentabilidade na instância escolar.

Espera-se - finalmente e essencialmente - provocar a transição das escolas para o conceito Escola Sustentável, mas igualmente o desencadeamento continuado na coletividade escolar da incorporação de conhecimentos e comportamentos conscientes e saudáveis nos âmbitos sócio-econômico-ambientais, os 3 macroelos da visão abrangente:

a) social - respeito, ética, inclusão social, democracia, comunicação horizontal;

b) ambiental - consciência, atitude, responsabilidade, comprometimento continuado;

c) econômico - desperdício zero, baixo consumo, preservação do patrimônio físico.

Para os que desejam fazer da sua escola um lugar vivo, pleno e sustentável de fato, ou seja, equilibrado ou trabalhando pelo seu equilíbrio entre as 3 macroáreas da sustentabilidade e suas 3 respectivas áreas de intersecções, que tenha a inclusão de seu espaço físico no PPP para contextualizações pedagógicas continuadas, terão no instrumento que o produto deste mestrado resulta um recurso. 


\section{REFERÊNCIAS}

ANDRÉ, Marli E. D. A. Estudo de Caso: seu potencial na educação. Cadernos de Pesquisa, n.49, Rio de Janeiro, 1984. p. 51-54,

ASSOCIAÇÃO BRASILEIRA DE NORMAS TÉCNICAS (ABNT). NBR $\mathbf{5 6 7 4}$ Manutenção de Edificações: procedimento. Rio de Janeiro, 1999.

ASSOCIATION FOR THE ADVANCEMENT OF SUSTAINABILITY IN HIGHER EDUCATION (AASHE). Stars ${ }^{\circledR}$ Technical Manual. Version 2.2. Philadelphia, Jun/2019.

BARDIN, Lawrence. Análise de conteúdo. Tradução: Luís Antero Reto e Augusto Pinheiro. Lisboa: Edições 70, 1977. 226 p.

BARONI, Margaret. Ambigüidades e deficiências do conceito de desenvolvimento sustentável. Revista de administração de empresas, v. 32, n. 2, p. 14-24, abr/jun. 1992. Disponível em: <http://www.scielo.br/pdf/rae/v32n2/a03v32n2.pdf> Acesso em 27 mai 2019.

BIANCHI, Camila Santos Tolosa. Programa Nacional Escolas Sustentáveis: o fluxo de uma ideia no campo das políticas públicas de educação ambiental. 2016. 182 f. Dissertação (Mestrado em Educação) - Faculdade de Educação, Universidade de Brasília, Brasília, DF, 2016. Disponível em: <http://repositorio.unb.br/handle/10482/22696> Acesso em: 11 jan 2019.

BOGADO, A. M.; FREITAS, D. Programa Nacional Escolas Sustentáveis no Brasil: construindo estratégias para a sustentabilidade em contextos complexos. In: CONGRESO INTERNACIONAL SOBRE INVESTIGACIÓN EN DIDÁCTICA DE LAS CIENCIAS, 10., 2017, Sevilla. Enseñanza de las Ciencias, Vigo, ${ }^{\circ}$ extraordinario, p. 3111-3116, 2017. Disponível em: <https://ddd.uab.cat/pub/edlc/edlc_a2017nEXTRA/69__Programa_Nacional_Escolas_Sustentaveis_no_Brasil.pdf $>$ Acesso em 11 jan 2019.

BOLLINGER, F. P.; SCANDAR NETO, W. J. Indicadores de Desenvolvimento Sustentável para o Brasil. In: Estatísticas ambientais e indicadores de desenvolvimento sustentável para o Brasil. Avaliação e mensuração de impactos ambientais. Campinas: Unicamp, p. 271-297, 2004.

BRASIL, Ministério da Educação e do Desporto - Coord. de Educação Ambiental. Implantação da Educação Ambiental no Brasil. Brasília, DF, 1998. 166p.

Lei no. 9.795, de 27 de abril de 1999. Dispõe sobre a educação ambiental, institui a Política Nacional de Educação Ambiental e dá outras providências. Disponível em: $<$ http://www.planalto.gov.br/ccivil_03/leis/19795.htm>. Acesso em: 08 jan.2019.

. Ministério do Meio Ambiente/PNUD. Agenda 21 Brasileira: resultado da consulta nacional. Brasília, DF, 2002. 156 p. Disponível em: $<$ http://www.mma.gov.br/estruturas/agenda21/_arquivos/resultcons.pdf $>$ Acesso em 08 jan 2019.

(a). Ministério da Educação. Secretaria de Educação Continuada, Alfabetização e Diversidade. Educação Ambiental: aprendizes de sustentabilidade. Brasília, DF, 2007. 109 p. Disponível em: <http://portal.mec.gov.br/dmdocuments/publicacao2.pdf> Acesso em 24 de jun. de 2018. 
(b). Ministério do Meio Ambiente; Ministério da Educação. Comissão de meio ambiente e qualidade de vida na escola - Com-Vida. Série Documentos Técnicos, $\mathrm{n}^{\circ} 10$. 1.ed. Brasília, $2007 . \quad 30 \quad$ p. $\quad$ Disponível em: $<$ http://portal.mec.gov.br/index.php?option=com_docman\&view=download\&alias=9921-doctecnico-10-com-vida\&category_slug=fevereiro-2012-pdf\&Itemid=30192> Acesso em 09 jan 2019.

(c). Ministério da Educação, Coordenação Geral de Educação Ambiental: Ministério do Meio Ambiente, Departamento de Educação Ambiental UNESCO. Vamos cuidar do Brasil: conceitos e práticas em educação ambiental na escola, Brasília, DF, 2007. 248 p. Disponível em: <http://portal.mec.gov.br/dmdocuments/publicacao3.pdf> Acesso em 09 jan 2019.

- Ministério da Educação, Secretaria de Educação Continuada, Alfabetização e Diversidade. Processo Formativo Escolas Sustentáveis e Com-Vida. Brasília, DF, 2010. 45 p. Disponível em: <https://nova-escolaproducao.s3.amazonaws.com/CKqCGUArHjks35wauWGVTKz7n3yzjuta9NbazJztf6rKFDBt stX6qDjwy6rf/blog-sustentabilidade-escolas-sustentantaveis-com-vidas2010-mec.pdf> Acesso em 09 jan 2019.

(a). Ministério da Educação. Secretaria de Educação Continuada, Alfabetização e Diversidade. Formando Com-Vida: Comissão de Meio Ambiente e Qualidade de Vida na Escola, construindo Agenda 21 na escola. Brasília, DF, 2012. 53 p. Disponível em: $<$ http://portal.mec.gov.br/index.php?option=com_docman\&view $=$ download\&alias $=16493$ formando-com-vida-agenda21-na-escola\&category_slug=outubro-2014-pdf\&Itemid=30192> Acesso em 09 jan 2019.

(b). Ministério da Educação. Secretaria de Educação Continuada, Alfabetização, Diversidade e Inclusão. Vamos cuidar do Brasil com escolas sustentáveis: educando-nos para pensar e agir em tempos de mudanças socioambientais globais. Brasília, DF, 2012. 46 p. Disponível em: $<$ http://www.seduc.go.gov.br/documentos/nucleomeioambiente/material2013/caderno.pdf $>$. Acesso em 24 de jun. de 2018.

(c). Ministério da Educação. Conselho Nacional de Educação. Resolução no 2, de 15 de junho de 2012: estabelece as diretrizes curriculares nacionais para a educação ambiental. Brasília, DF, 2012. Disponível em: $<$ http://portal.mec.gov.br/index.php?option=com_docman\&task=doc_download\&gid=10988 \&Itemid=> Acesso em 08 de jan 2019.

(a). Ministério da Educação; Secretaria de Educação Continuada, Alfabetização, Diversidade e Inclusão. Manual Escolas Sustentáveis - Resolução CD/FNDE No 18, de 21 de maio de 2013. Brasília, DF, 2013. Disponível em: $<$ http://pdeinterativo.mec.gov.br/escolasustentavel/manuais/Manual_Escolas_Sustentaveis_v \%2005.07.2013.pdf $>$ Acesso em 09 jan 2019.

(b). Ministério da Educação, Coordenação-Geral de Educação Ambiental/DPDHUC/SECADI. Programa Nacional Escolas Sustentáveis. Brasília, DF, out 2013. 11 p. Disponível em: $<$ https://cursosdh.files.wordpress.com/2013/10/programa-nacionalescolas-sustentc3a1veis-28-10-2013.pdf > Acesso em 10 jan 2019. 
(c). Ministério do Meio Ambiente; Ministério da Educação. IV Conferência Nacional Infantojuvenil pelo Meio Ambiente: Relatório Final. Brasília, DF, nov. 2013. 72 p. Disponível em: < http://portal.mec.gov.br/pnaes/194-secretarias-112877938/secad-educacaocontinuada-223369541/17455-conferencia-infanto-juvenil-pelo-meio-ambiente-novo $>$ Acesso em 10 jan 2019.

(a). Ministério da Educação; Secretaria de Educação Continuada, Alfabetização, Diversidade e Inclusão; Diretoria de Políticas de Educação em Direitos Humanos e Cidadania; Coordenação-geral de Educação Ambiental. Programa Dinheiro Direto na Escola - PDDE Escolas Sustentáveis: guia de orientações operacionais. Brasília, DF, 2014. 20 p.

(b). LEI no 13.005, DE 25 DE JUNHO DE 2014: aprova o Plano Nacional de Educação - PNE e dá outras providências. Brasília, DF, 2014. Disponível em: $<$ http://www2.camara.leg.br/legin/fed/lei/2014/lei-13005-25-junho-2014-778970publicacaooriginal-144468-pl.html> Acesso em: 10 jan 2019.

(c). Ministério da Educação; Fundo Nacional de Desenvolvimento da Educação; Conselho Deliberativo. Resolução $\mathbf{n}^{0}$ 18, de 3 de setembro de 2014. Brasília, DF, 2014. Disponível em: $<$ http://www.lex.com.br/legis_25919903_resolucao_n_18_de_3_de_setembro_de_2014.aspx $>$ Acesso em 10 jan 2019.

(d). Ministério das Relações Exteriores. Negociações da Agenda de Desenvolvimento Pós- 2015: Elementos orientadores da posição brasileira. 2014. Disponível em: $<$ http://www.itamaraty. gov.br/images/ed_desenvsust/ODS-pos-bras.pdf $>$. Acesso em: $10 \mathrm{fev}$. 2020.

Ministério do Meio Ambiente; Ministério da Educação. V Conferência Nacional Infantojuvenil pelo Meio Ambiente. Brasília, DF, dez 2017. 13 p. Disponível em: $<\mathrm{http}$ //conferenciainfanto.mec.gov.br/images/material_grafico/apresentacao-V-CNIJMAresumida-04-dezembro-2017.pdf $>$ Acesso em 10 jan 2019.

. Ministério do Meio Ambiente; Ministério da Educação. Educação Ambiental por um Brasil sustentável - ProNEA: marcos legais e normativos - Brasília, DF, MMA 2018. 104 p. Disponível em: $<$ http://mma.gov.br/images/arquivo/80219/images/ProNEA_2018_versaofinal.pdf $>$ Acesso em 09 jan 2019

. Ministério do Meio Ambiente; Ministério da Educação. Recomendação Conama n⿳11, de 04 de maio de 2011. In: Educação Ambiental por um Brasil sustentável - ProNEA: marcos legais e normativos - Brasília, DF, MMA 2018. p. 68-70.

CAPRA, Fritjof (1982). O Ponto de Mutação. Tradução: Álvaro Cabral. São Paulo: Cultrix, 2006. 464 p.

CARSON, Rachel. Primavera Silenciosa. Tradução: Raul de Polillo. São Paulo: Melhoramentos, 1969.

CELlARD, André. A Análise Documental. In: POUPART, J. et al. A Pesquisa Qualitativa: enfoques: epistemológico e metodológicos. Petrópolis, Vozes, 2008, p. 295-316. 
COLE, Laura B. The teaching green school building: A framework for linking architecture and environmental education. Environmental Education Research, v. 20, n. 6, p. 836-857, 2014.

COLE, Laura B.; HAMILTON, Erin M. Can a green school building teach? A pre-and postoccupancy evaluation of a teaching green school building. Environment and Behavior, v. 52, 2020.

CONSELHO DE ARQUITETURA E URBANISMO DO BRASIL (CAU/BR). Código de Ética e Disciplina do Conselho de Arquitetura e Urbanismo do Brasil. Brasília, DF, 2015.

DAVIS, Julie M.; COOKE, Sue M. Educating for a healthy, sustainable world: an argument for integrating health promoting schools and sustainable schools. Health Promotion International, v. 22, n. 4, p. 346-353, 2007.

DEPARTMENT OF ECONOMIC AND SOCIAL AFFAIRS OF THE UNITED NATIONS SECRETARIAT (DESA). Indicators of Sustainable Development: Guidelines and Methodologies (p. 93). New York, USA: UN DESA, 2007.

FLICK, Uwe. Uma Introdução à Pesquisa Qualitativa. Porto Alegre: Bookman, 2004. 312 p.

FORD, Alan et al. Designing the sustainable school. Australia: Images Publishing, 2007. 256 p.

FRANQUESA-SOLER, Montserrat; SANDOVAL-RIVERA, Juan Carlos A. Mentoring Program to achieve SDGs in local contexts: a case study in communities from southern Mexico. Sustainability: The Journal of Record, v. 12, n. 2, p. 109-114, 2019.

FULLER, Buckminster (1969). Manual de Instruções para a Nave Espacial Terra. 2a ed. Tradução: Luís Torres Fontes. Porto: Via Optima, 1998. 81 p.

FUNDAÇÃO PARA O DESENVOLVIMENTO DA EDUCAÇÃO, Portal eletrônico. Apresenta serviços sustentáveis para escolas. Disponível em: $<$ http://www.fde.sp.gov.br/PagePublic/Interna.aspx?codigoMenu=219> Acesso em 3 fev 2019.

GELFAND, Lisa. Sustainable school architecture: design for elementary and secondary schools. New Jersey: John Wiley \& Sons, 2010. 339 p.

GONÇALVES, Joana Carla Soares; DUARTE, Denise Helena Silva. Arquitetura sustentável: uma integração entre ambiente, projeto e tecnologia em experiências de pesquisa, prática e ensino. Ambiente construído, v. 6, n. 4, p. 51-81, 2006.

GORDON, Douglas E. Green Schools as High Performance Learning Facilities. National Clearinghouse for Educational Facilities, 2010.

GOUGH, Noel \& GOUGH, Annette. The Green Schools Movement Around the World. In: PRESENTATION TO ASIAN STUDIES FACULTY AND STUDENTS, UNIVERSITY OF WESTERN AUSTRALIA, 2019. Disponível em: < https://www.researchgate.net/publication/332393660_The_Green_Schools_Movement_Aroun d_the_World $>$ Acesso em 14 jan 2020. 
HARB, S.; ELHAGGAR, S. M.; SEWILAM, H. Developing sustainable school guidelines: the case of Egypt. In: E3S Web of Conferences. EDP Sciences, 2019. p. 03004.

INSTITUTO BRASILEIRO DE GEOGRAFIA (IBGE). Indicadores de desenvolvimento sustentável: Brasil 2015. Coordenação de Recursos Naturais e Estudos Ambientais [e] Coordenação de Geografia. Rio de Janeiro: IBGE, 2015. 352p.

INSTITUTO DE PESQUISA ECONÔMICA APLICADA (IPEA). Objetivos de desenvolvimento do milênio: relatório nacional de acompanhamento. 2014.

JORGE Graça, F..; COSTA, Marta M. da. High Performance School Buildings in Portugal: A Life Cycle Perspective. CELE Exchange, Centre for Effective Learning Environments, 2011/09. Paris: OECD Publishing, 2011. Disponível em: $<$ http://dx.doi.org/10.1787/5kg0lkznt3bp-en> Acesso em 14 jan 2019.

KATES, Robert W.; PARRIS, Thomas M.; LEISEROWITZ, Anthony A. What is sustainable development? Goals, indicators, values, and practice. Environment: science and policy for sustainable development. Environment: Science and Policy for Sustainable Development, v. 47, n. 3, p. 8-21, 2005.

KOWALTOWSKI, Doris C. C. K. Arquitetura Escolar: o Projeto do Ambiente de Ensino. São Paulo, Oficina de Textos, 2011. 270 p.

KUUSKORPI, M.; GONZÁLEZ, N. Cabellos. The Future of the Physical Learning Environment: School Facilities that Support the User. CELE Exchange, Centre for Effective Learning Environments, 2011/11. Paris, OECD Publishing, 2011. Disponível em: $<\mathrm{http}$ ://dx.doi.org/10.1787/5kg0lkz2d9f2-en> Acesso em 14 jan 2019.

LEGAN, Lúcia. A escola sustentável: eco-alfabetização pelo ambiente. São Paulo: Imprensa Oficial \& Pirenópolis: IPEC, 2007. Disponível em: < https://issuu.com/ecocentro/docs/escolasustentavel> Acesso em 3 jan 2021.

LEGAN, Lúcia. Criando Habitats na Escola Sustentável: livro do educador. São Paulo: Imprensa Oficial \& Pirenópolis: IPEC, 2009. 96 p.

LÉLÉ, Sharachchandra M. Sustainable development: a critical review. World development, v. 19, n. 6, p. 607-621, 1991.

LÜCK, Heloísa et al. A Escola Participativa: o trabalho do gestor escolar. Petrópolis: Vozes, 2011. $160 \quad$ p. $\quad$ Disponível $\quad$ em: https://books.google.com.br/books?id=k4owDwAAQBAJ\&hl=pt-BR> Acesso em 3 jan 2021.

LÜDKE, M. e ANDRÉ, M. (1986) Pesquisa em Educação: abordagens qualitativas. São Paulo: EPU, 2012. 99 p.

MAHAT, Hanifah et al. Model development on awareness of education for sustainable schools development in Malaysia. Indonesian Journal of Geography, v. 48, n. 1, p. 37-46, 2016.

MALAGUZZI, Loris. Part I: History. The hundred languages of children: The Reggio Emilia approach-Advanced reflections, v. 49, 1998. 
MCDONOUGH, William; BRAUNGART, Michael. Cradle to cradle: remaking the way we make things. North point press, 2002. 208 p.

MEADOWS, Donella H. Leverage points: Places to intervene in a system. 1999.

MEADOWS, Donella H. et al. The limits to growth: A Report for the Club of Rome's Project on the Predicament of Mankind. New York, Universe Books, 1972. 205 p.

MOORE, K. Schools of the Future Initiative in California. CELE Exchange, Centre for Effective Learning Environments, 2011/07. Paris: OECD Publishing, 2011. Disponível em: $<\mathrm{http}$ //dx.doi.org/10.1787/5kg5c8c30mkk-en> Acesso em 14 jan 2019.

MOORE, Mary et al. Extending communities of practice: a partnership model for sustainable schools. Environment, Development and Sustainability, v. 21, n. 4, p. 1745-1762, 2019.

NICOLESCU, Basarab. Um Novo Tipo de Conhecimento: transdisciplinaridade. In: Educação e transdisciplinaridade. Brasília, UNESCO/USP, 2000. p. 9-25. Disponível em: $<$ https://unesdoc.unesco.org/ark:/48223/pf0000127511> Acesso em 10 jan 2019.

OECD. OECD School User Survey: Improving Learning Spaces Together. 2018. 51 p. Disponível em: <http://dx.doi.org/10.1787/eco_surveys-bra-2018-en> Acesso em 11 jan 2019.

ORGANIZAÇÃO DAS NAÇÕES UNIDAS (ONU). Conferencia Das Nacões Unidas Sobre O Meio Ambiente Humano, 5-16 de junho de 1972, Estocolmo. Declaração de Estocolmo sobre o ambiente humano. Estocolmo, Junho 1972. Tradução livre. 6 p. Disponível em: $<$ http://www.direitoshumanos.usp.br/index.php/Meio-Ambiente/declaracao-de-estocolmosobre-o-ambiente-humano.html $>$ Acesso em 3 jan 2021.

BRASIL; ORGANIZAÇÃO DAS NAÇÕES UNIDAS (ONU). Transformando nosso mundo: A agenda 2030 para o desenvolvimento sustentável. Tradução: Centro de Informação das Nações Unidas para o Brasil (UNIC Rio), out. 2015. Disponível em: $<$ https://nacoesunidas.org/wp-content/uploads/2015/10/agenda2030-pt-br.pdf $>$ Acesso em 10 jan 2019.

PIRES, Álvaro P. Amostragem e pesquisa qualitativa: ensaio teórico e metodológico. Poupart J, Deslauriers JP, Groulx LH, Lapemère A, Mayer R, Pires AP, organizadores. A pesquisa qualitativa: enfoques epistemológicos e metodológicos. Petrópolis: Editora Vozes, p. 154-211, 2008.

POMBO, Olga. Interdisciplinaridade e Integração dos Saberes. Laboratório Interdisciplinar sobre Informação e Conhecimento, v.1, n.1, março 2005, p. 3-15. Disponível em: $<$ http://revista.ibict.br/liinc/article/view/3082> Acesso em 10 jan 2019.

POUPART, Jean. A entrevista de tipo qualitativo: considerações epistemológicas, teóricas e metodológicas. In. Poupart $\mathrm{J}$, et al, organizadores. A pesquisa qualitativa: enfoques epistemológicos e metodológicos. Petrópolis: Editora Vozes, p. 215-253, 2008.

PROGRAMA DAS NAÇÕES UNIDAS PARA O DESENVOLVIMENTO (PNUD). Acompanhando a agenda 2030 para o desenvolvimento sustentável: subsídios iniciais do Sistema das Nações Unidas no Brasil sobre a identificação de indicadores nacionais referentes aos objetivos de desenvolvimento sustentável/Programa das Nações Unidas para o Desenvolvimento. Brasília: PNUD, 2015. 250 p. 
REDCLIFT, Michael. Sustainable development: needs, values, rights. Environmental values, p. 3-20, 1993. Disponível em: <https://www.jstor.org/stable/pdf/30301305.pdf $>$ Acesso em 27 may 2019.

SÁ-SILVA, J. R.; ALMEIDA, C. D.; GUINDANI, J. F. Pesquisa Documental: pistas teóricas e metodológicas. Revista Brasileira de História \& Ciências Sociais, n. 1. Rio Grande do Sul, jul 2009. Disponível em: <https://www.rbhcs.com/rbhcs/article/view/6> Acesso em 11 jan 2019.

SANTOS, Boaventura de S. Um Discurso sobre as Ciências na Transição para uma Ciência Pós-moderna. Estudos Avançados, v.2 n.2, São Paulo, 1988. Disponível em: $<$ http://dx.doi.org/10.1590/S0103-40141988000200007> Acesso em 11 jan 2019.

SHARMA, P. K. et al. Positive actions for the sustainable development goals. Foundation for Environmental Education, 2018. 48 p.

SILVA, Maria A.; SANTANA, Luiz C. Programa Nacional Escolas Sustentáveis: a implementação em quatro escolas municipais de João Pessoa/PB. REMEA-FURG, Rio Grande do Sul, v. 35, n. 1, p. 333-352, jan./abr. 2018. Disponível em: $<$ https://periodicos.furg.br/remea/article/view/7513> Acesso em 11 jan 2019.

STRONG-WILSON, Teresa; ELLIS, Julia. Children and place: Reggio Emilia's environment as third teacher. Theory into practice, v. 46, n. 1, p. 40-47, 2007.

THIOLLENT, Michel. Metodologia da pesquisa-ação. São Paulo: Cortez e Ed. Autores Associados, 1986. 107 p. (Coleção temas básicos de pesquisa-ação).

TUCKER, Richard; IZADPANAHI, Parisa. Live green, think green: Sustainable school architecture and children's environmental attitudes and behaviors. Journal of Environmental Psychology, v. 51, p. 209-216, 2017.

UNESCO-UNEP. The Belgrade Charter: A Global Framework for Environmental Education. Environmental Education Newsletter. Paris: Connect, v. I, n. 1, jan 1976.

UNESCO; IBAMA. Educação ambiental: as grandes diretrizes da Conferência de Tbilisi. Brasília: 1997. 154 p.

UNITED NATIONS DEVELOPMENT PROGRAM (UNDP). The Millennium Development Goals Report 2015. 2015.

UNITED NATIONS SUSTAINABLE DEVELOPMENT (UNSD). United Nations Conference on Environment \& Development. Agenda 21. Rio de Janeiro, 1992.

USGBC. LEED 2009 For Schools New Construction and Major Renovations. USGBC, 2016. $109 \mathrm{p}$. 


\title{
TERMO DE CONSENTIMENTO LIVRE E ESCLARECIDO
}

Declaro, por meio deste termo, que concordei em conceder à pesquisa intitulada $\underline{O}$ espaço escolar sustentável como educador, desenvolvida por Yara Santucci Barreto, o conteúdo da experiência profissional pregressa colhido durante o período de junho de 2012 à outubro de 2014, realizada nesta instância escolar sob minha direção. Fui informado, ainda, de que a pesquisa é orientada pela prof $\mathrm{Dr}^{2}$ Fernanda da Rocha Brando Fernandez, a quem poderei contatar/ consultar a qualquer momento que julgar necessário por meio do telefone $n^{\circ} \underline{14}$ $\underline{98123.8548 \text { ou e-mail ferbrando@fffclrp.usp.br. }}$

Afirmo que aceitei conceder tal espaço de pesquisa gentilmente, sem receber qualquer incentivo financeiro ou ter qualquer ônus e com a finalidade exclusiva de colaborar para o bom andamento da pesquisa. Fui informado sobre os objetivos estritamente acadêmicos do estudo, que seguem:

\begin{abstract}
Definir um contorno global do conceito Escola Sustentável e elencar seus princípios universais a serem adotados no produto final, o Guia de Princípios da Escola Sustentável, que pretende facilitar e simplificar a localização dos potenciais e demandas em sustentabilidade na instância escolar, tanto pela comunidade escolar e seus gestores como por profissionais por ela contratados. Os alinhamentos que desse instrumento se revertam, poderão favorecer a transição das escolas para o conceito Escola Sustentável, movimento global que cresce há décadas visando_à instância escolar realizar valores teorizados em sala de aula acerca da sustentabilidade, consolidar tal conceito por meio da sua incorporação em hábitos sócio-econômicoambientais conscientes e continuados dentro da própria comunidade e, dessa forma, empoderar e capacitar as novas gerações e futuras à solução de problemas complexos em direção ao equilibrio entre esses valores.
\end{abstract}

Minha colaboração segue de forma anônima, por meio de vivências, entrevistas informais, levantamentos de dados e encaminhamentos junto a outros atores desta escola para que os trabalhos de mapeamento diagnóstico e obras de adequações no espaço físico desta escola pudessem ser realizadas ao longo do periodo supracitado por esta mestranda, então contratada como arquiteta para a elaboração e execuções de tais serviços.

Declaro também não ser de responsabilidade da escola ou minha pessoal a sistematização e tratamento dos dados coletados que levam a conclusões no trabalho acadêmico que apenas a autora e sua orientadora devem responder.

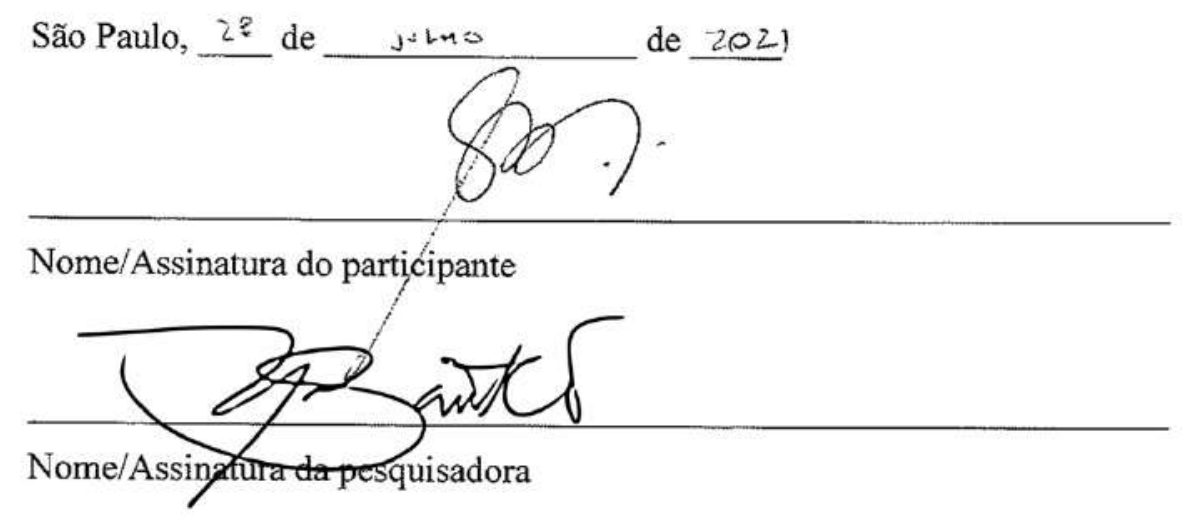




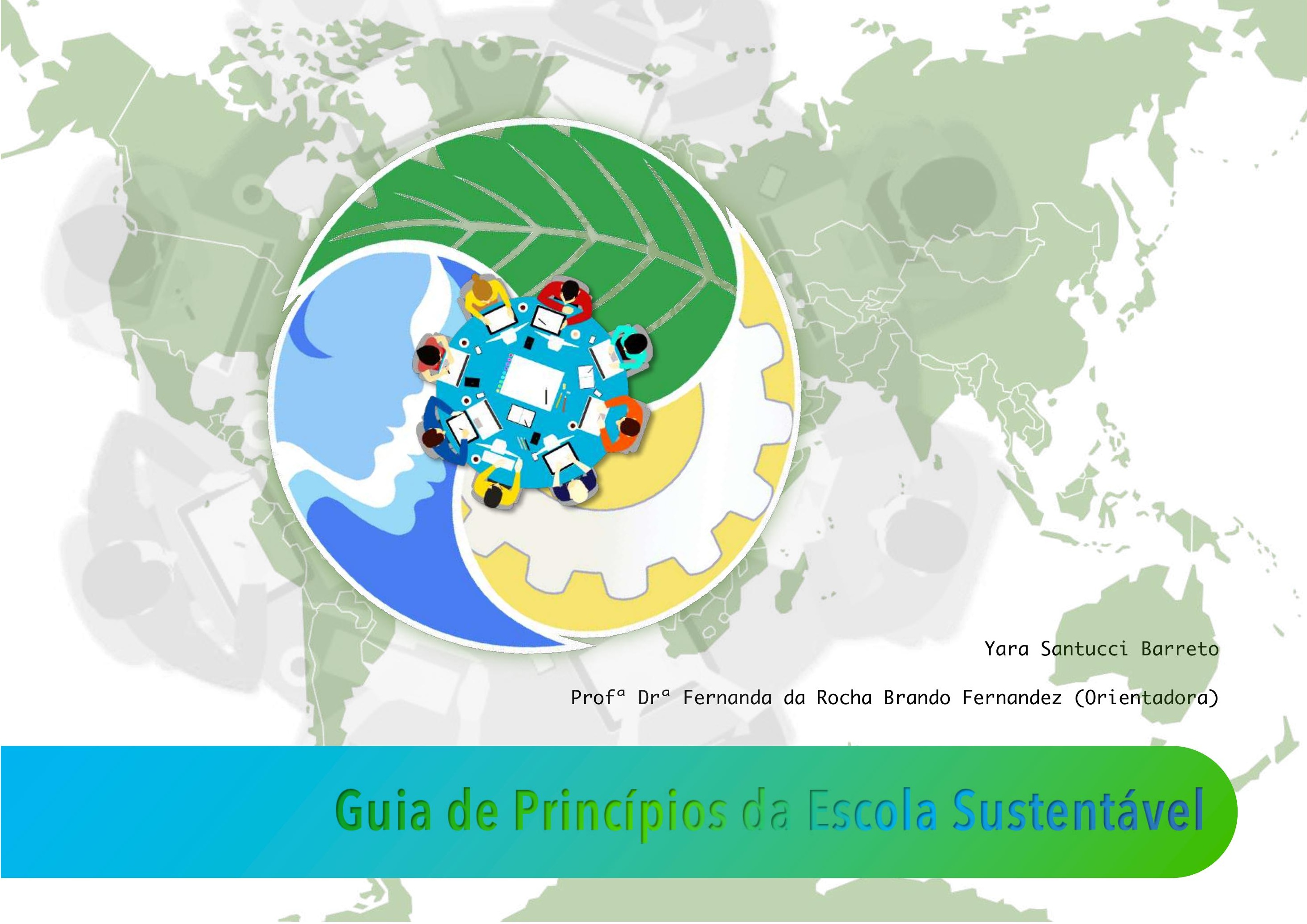




\section{TERMO DE LICENCEAMENTO}

Esse Produto Educacional está licenciado pela Creative Commons, atribuição uso nãocomercial/compartilhamento sob a mesma licença 4.0 Brasil. Para ver uma cópia desta licença, visite o endereço https://creativecommons.org/licenses/by-nc- sa/4.0/deed.pt_BR ou envie uma carta para Creative Commons, 171 Second Street, Suit 300, San Francisco, Califórnia 94105, USA.

Link de acesso:

https://www.oercommons.org/courses/guia-de-princi-pios-da-escola-sustenta-vel-pdf 


\section{Guia de Princípios da Escola Sustentável}

Guia desenvolvido pela Mestranda Yara Santucci Barreto, sob a Supervisão e Orientação da Professora Doutora Fernanda da Rocha Brando Fernandez, como "Produto Final" do Mestrado Profissional em Ciências Ambientais, através do Programa de PósGraduação em Rede Nacional para o Ensino de Ciências Ambientais, PROFCIAMB, através da Escola de Engenharia de São Carlos, EESC, USP de São Carlos, em parceria com a Agência Nacional de Águas (ANA).

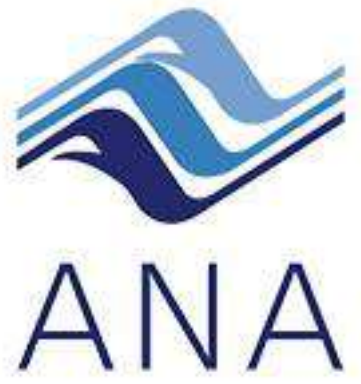

\section{EES[・USP}

Escola de Engenharia de São Carlos Assistência Técnica Acadêmica

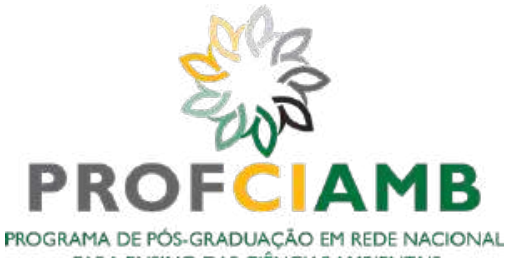

PROGRAMA DE POSS-GRADUACÁO EM REDE NACIO
PARA ENSINO DAS CIENCIASAMBIENTAIS

São Carlos

2020 


\section{ÍNDICE}

\begin{tabular}{ll}
\hline INTRODUÇÃO & 4 \\
\hline INSTRUÇÕES DE USO & 6 \\
LEGENDA DE NOMENCLATURAS & 7 \\
\hline GUIA DE PRINCÍPIOS DA ESCOLA SUSTENTÁVEL & \\
IDENTIDADE (QUEM SOMOS) & 8 \\
MARCO ZERO (COMO ESTAMOS) & \\
VISÃO SISTÊMICA (COMO ESTAMOS PERANTE O ENTORNO E O MUNDO) & 10 \\
GESTÃO (RUMOS E METAS) & 12 \\
CAPACITAÇÃO (PREPARAR) & 14 \\
REDE (ESTRUTURAR) & 17 \\
ESPAÇO EDUCADOR (AÇÃO) & 21 \\
SAÚDE (AÇÃO) & 24 \\
CONSUMO E RESÍDUOS (AÇÃO) & 26 \\
ENERGIA (AÇÃO) & 28 \\
ÁGUA E ESGOTO (AÇÃO) & 29 \\
PAISAGEM (AÇÃO) & 31 \\
TRANSPORTE (AÇÃO) & 33 \\
MANUTENÇÃO (AÇÃO) & 34 \\
ÉTICA (VALOR) & 36 \\
CIDADANIA (VALOR) & 38 \\
EXEMPLOS PRÁTICOS DE APLICAÇÕES & 41 \\
\hline REFERÊNCIAS & 48
\end{tabular}


0 espaço físico das escolas, independente de sua solução arquitetônica, com frequência vem sendo utilizado como mero meio passivo para o ensino e negligenciado o seu potencial educador por meio de soluções paliativas de uso e conservação improvisadas, imediatistas e sem planejamento, tornando-se desconfortável, ambientalmente inadequado ou padronizado, pedagogicamente antagônico aos valores ético-ambientais ensinados em sala de aula e, portanto, distante do conceito Escola Sustentável pretendido.

\section{Este Guia de Principios da Escola Sustentável tem por}

objetivo instrumentalizar e orientar gestores e a comunidade escolar, de forma compartilhada e conjunta, a detectarem nos respectivos domínios de sua instância escolar as adequações que se façam necessárias, de ordem física e também social e econômica, de forma que as ações de incrementos que desse instrumento se revertam favoreçam a transição das escolas para o conceito Escola Sustentável e, dessa forma, se alinhem à Educação para o Desenvolvimento Sustentável (EDS), preconizada desde a Conferência da ONU Rio-92 e sua Agenda 21, momento que catalisaria ao redor do mundo 0 desenvolvimento de programas educacionais dedicados a incorporar a sustentabilidade nas escolas. Um número crescente de escolas ao redor do mundo vem se filiando a esses programas desde então, como uma busca para se adequarem ao contexto atual de demandas globais, apresentadas desde há décadas à sociedade por relatórios e agendas mundiais.

0 conceito Escola Sustentável a seguir apresentado, foi construído a partir de um mosaico global de contribuições extraídas de títulos representativos sobre o tema ao redor do mundo: documentos oficiais - legislações, resoluções, declarações, manuais, agendas ou políticas públicas publicados na internet em sites do governo brasileiro e de instituições governamentais e não-governamentais notórias e reconhecidas nacional e internacionalmente e artigos científicos - publicados entre 2000 a 2020, período de maior maturidade quanto ao desenvolvimento das pesquisas sobre sustentabilidade. Os conteúdos foram analisados por metodologia científica da análise documental e bibliográfica com análise de conteúdo.

0 presente guia, produto resultante dessa pesquisa, vem elencar 282 princípios balizadores acerca dos aspectos até hoje contemplados por autores atentos há décadas ao tema Escolas Sustentáveis, abrangentes o bastante para assegurar uma transição real para a EDS. Trata-se de um repertório reunido de forma inédita como forma de obter o estado da arte 
do que é possivel chamar de Escola Sustentável e que vem contribuir para o alinhamento das escolas às agendas internacionais já criadas.

0 conceito Escola Sustentável uma vez em processo de implantação na instância escolar, somente trará benefícios e não apenas à instância escolar - enquanto instituição pedagógica de ensino ou patrimônio físico e cultural a ser conservado - mas essencialmente à comunidade que ali se conforma e à sociedade que ajuda a formar, enquanto incubabora de cidadãos responsáveis, críticos, inclusivos e próativos - o que consequentemente polinizará a intenção genuína e 0 encorajamento em mover esforços nessa direção.

0 que garante 0 interesse e 0 envolvimento das escolas em um sistema de autoavaliação e reflexão como o que este guia propõe?

Nada garantirá essa mobilização, além da profunda compreensão e conscientização de que implantar a sustentabilidade dentro e fora da escola se tornou "um imperativo moral e ético" (p. 72), como foi apontado logo em 1997 na Declaração de Thessaloniki (BRASIL, 1998, p. 71-74), e também emergente, diante do cenário sistêmico crítico atingido a partir das ações antrópicas - fontes não renováveis reduzidas, biodiversidade prejudicada, poluição atmosférica e das águas - por uma população que em breve alcançará 8 bilhões de habitantes.

Espera-se essencialmente provocar a transição das escolas para o conceito Escola Sustentável, mas igualmente 0 desencadeamento continuado na coletividade escolar da incorporação de conhecimentos e comportamentos conscientes e saudáveis nos âmbitos sócio-econômico-ambientais, os 3 macroelos da visão abrangente:

SOCIAL - respeito, ética, inclusão social, democracia, comunicação horizontal;

AMBIENTAL - consciência, atitude, responsabilidade, comprometimento continuado;

ECONÔMICO - desperdício zero, baixo consumo, preservação do patrimônio físico.

Para os que desejam fazer da sua escola um lugar vivo, pleno e sustentável de fato, equilibrado entre as 3 macroáreas da sustentabilidade e suas 3 respectivas áreas de intersecções, e que tenha o seu espaço físico inserido no PPP para contextualizações pedagógicas continuadas, terão neste instrumento um recurso.

\section{2on}




\section{INSTRUÇÕES DE USO}

COMPOSIÇÃO DE GRUPO - 0 preenchimento da última coluna presente em todas as tabelas que compõem o guia a seguir será em conjunto por quantos forem os atores representativos da comunidade escolar e o mais diversificados possivel, em idade, classe social, função, etc. Pais também poderão compor o grupo, caso sejam atuantes nos espaços físicos da escola e assim tenham repertório válido para avaliá-lo.

ROTINA - Cabe à cada grupo formado definir o ritmo, modelo e dinâmica dos encontros para as discussões, com ou sem intervalos, sendo o mais importante prolongar a experiência, torná-la um hábito continuado, e com isso potencializar 0 desdobramento do autoconhecimento como forma de fortalecer o conjunto de valores da escola, apropriação e pertencimento.

SEQUÊNCIA - 0 grupo representativo avaliará, no prazo de tempo e ritmo estipulado em comum acordo, como cada um dos 282 princípios a seguir elencados em cada etapa do processo vem sendo aplicado na instância escolar. A sequência das autoavaliações poderá ser variada em função da realidade de cada escola, embora o ideal seja buscar seguir as etapas conforme o guia apresenta e de forma o mais linear possivel, uma vez que são evolutivas, ou seja, dependem em grande parte ou ao menos se beneficiam do amadurecimento da etapa anterior e apresentam uma sequência lógica que aparecerá sempre intitulada no alto e início de cada tabela: "Quem Somos", "Como Estamos", "Como Estamos Perante o Entorno e o Mundo", "Rumos e Metas", "Preparar", "Estruturar", "Ação" (8) e "Valor" (‡).

DICA - Atenção sempre aos ícones orientativos situados na coluna à esquerda das tabelas e que se referem a cada um dos princípios elencados a serem trilhados, pois sinalizam como proceder para melhor alcançá-lo. Consulte sempre a Legenda de Nomenclaturas na próxima página para conhecer esses ícones e os procedimentos aos quais se referem.

A comunidade poderá realizar periodicamente suas comemorações acerca de suas evoluções!

Boa sorte! 


\section{LEGENDA DAS NOMENCLATURAS}

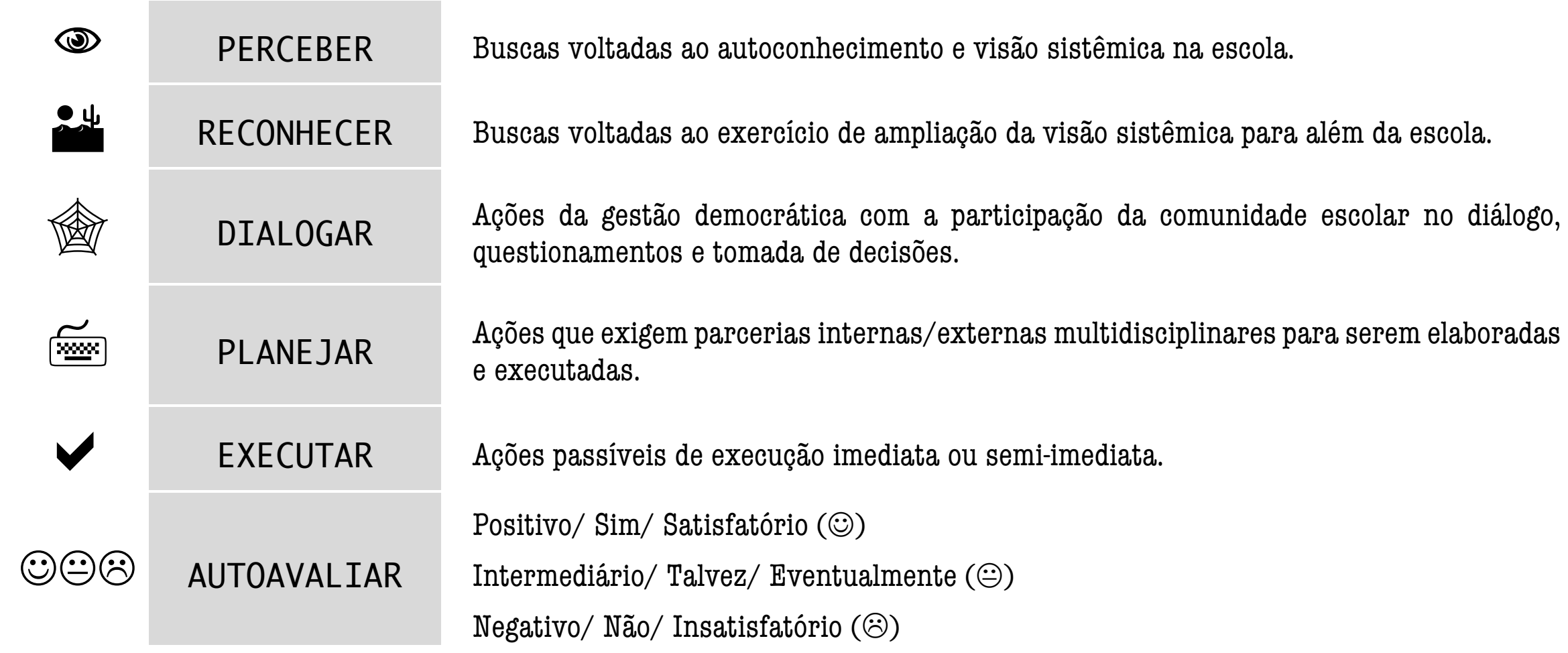




\begin{tabular}{|c|c|c|}
\hline & (4) & $\begin{array}{l}\text { 1. Partilhar da vida diária de toda a comunidade escolar, autoavaliar comportamentos em relação a si mesmo, aos } \\
\text { outros e aos ambientes que o cercam. }\end{array}$ \\
\hline & (4) & $\begin{array}{l}\text { 2. Reconhecer o patrimônio cultural, história e tradições (se indígena, oral, ou outros conhecimentos tradicionais) } \\
\text { herdadas no ideário escolar e sua preservação. }\end{array}$ \\
\hline & (3) & $\begin{array}{l}\text { 3. Avaliar se ecossistemas locais e prioridades ambientais geograficamente específicas interferem na realidade } \\
\text { escolar. }\end{array}$ \\
\hline$\stackrel{\leftarrow}{\underline{E}}$ & (4) & $\begin{array}{l}\text { 4. Reconhecer na escola os seus diferentes aspectos sociais, culturais, ambientais e econômicos inter-relacionados; } \\
\text { avaliar a preservação e desenvolvimento desse ideário. }\end{array}$ \\
\hline 岂 & (4) & $\begin{array}{l}\text { 5. Buscar conhecer as origens dos problemas já vivenciados pela comunidade escolar ou em curso e identificar suas } \\
\text { consequências. }\end{array}$ \\
\hline & (D) & 6. Analisar periodicamente o conjunto de prioridades, desafios, oportunidades e eventuais restrições. \\
\hline & (4) & $\begin{array}{l}\text { 7. Avaliar periodicamente os valores sociais presentes na comunidade, os conhecimentos, vocações e habilidades } \\
\text { disponiveis na comunidade, as atitudes e competências necessários para a conservação do meio ambiente. }\end{array}$ \\
\hline & $\checkmark$ & 8. Ações para com o fortalecimento do compromisso com a identidade da escola. \\
\hline
\end{tabular}


9. Georreferenciamento da escola no mapa do município; examinar ao vivo o terreno da escola e a paisagem do entorno, condições ecológicas, possivveis áreas de risco relativas à erosão, enchentes, secas, vendavais, etc. é um reconhecimento fundamental.

(a)

10. Realizar cadastro de biodiversidade na escola e no entorno.

(a)

11. Verificar se fornecimento de água potável na escola é regular e em quantidade e qualidade suficientes; ter ciência de onde vem a água consumida pela escola.

(2)

12. Calcular o volume do esgoto gerado pela escola e conhecer o seu destino.

\begin{tabular}{|c|c|}
\hline (1) & $\begin{array}{l}\text { 13. Ter ciência da origem e tipo da fonte de energia (rede elétrica, vento, água, gerador solar, combustivel) que } \\
\text { abastece a escola; verificar se fornecimento é regular. }\end{array}$ \\
\hline (2) & $\begin{array}{l}\text { 14. Levantamento das relações sociais na comunidade escolar e entre a comunidade escolar; preocupações sociais, } \\
\text { econômicas e ambientais urgentes; necessidades sociais, psicológicas e de desenvolvimento de toda a comunidade } \\
\text { escolar são reconhecimentos complexos necessários e exercitados. }\end{array}$ \\
\hline (a) & $\begin{array}{l}\text { 15. Realizar inventário e divulgação de emissões de gases de efeito estufa e poluentes atmosféricos resultantes das } \\
\text { atividades institucionais da escola. }\end{array}$ \\
\hline (4) & 16. Explorar e reconhecer o espaço escolar e analisar as suas condições físicas. \\
\hline (1) & 17. Levantamento dos aspectos positivos e áreas potenciais dos espaços escolares. \\
\hline$\approx$ & 18. Mapeamento das deficiências no edificio escolar, investigação de suas origens para diagnóstico. \\
\hline$\approx$ & $\begin{array}{l}\text { 19. Produzir indicadores físicos e ambientais e acompanhar a cada } 2 \text { anos por meio de auditoria autônoma da } \\
\text { infraestrutura escolar }\end{array}$ \\
\hline
\end{tabular}




\begin{tabular}{|c|c|}
\hline & $\begin{array}{l}\text { 20. Conhecer a bacia hidrográfica a que a localidade da escola pertence, cursos de água nos arredores e suas condições } \\
\text { quanto à poluição e assoreamento. }\end{array}$ \\
\hline & $\begin{array}{l}\text { 21. Conhecer fonte(s) de energia (rede elétrica, vento, água, gerador solar, combustível) que abastece(m) a região ou } \\
\text { potenciais locais. }\end{array}$ \\
\hline & $\begin{array}{l}\text { 22. Conhecer área(s) de vegetação nativa acessivel(is) existente(s) nas proximidades, o bioma ao qual pertence }(\mathrm{m}) \text { e } \\
\text { quais as [suas] características hoje e há } 20 \text { (ou mais) anos. }\end{array}$ \\
\hline & 23. Estudar sobre os ecossistemas e recursos naturais locais e verificar seus graus de integridade. \\
\hline & $\begin{array}{l}\text { 24. Verificar se empresas próximas tratam seus resíduos e como; se a prática de queimar o lixo ainda ocorre na } \\
\text { comunidade. }\end{array}$ \\
\hline & 25. Verificar se existem ciclovias perto da escola (se em meio urbano) e se normatizadas. \\
\hline 2 & $\begin{array}{l}\text { 26. Realizar atividades sensoriais e de integração com a natureza; ampliar o sentido de pertencimento dos seres } \\
\text { humanos à natureza; observar a diversidade das espécies de seres vivos são práticas continuadas. }\end{array}$ \\
\hline 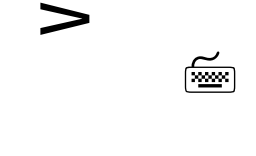 & $\begin{array}{l}\text { 27. Disponibilizar estratégias interdisciplinares no espaço escolar para ampliar o horizonte sustentável e científico } \\
\text { da sua comunidade como um todo, cientes do papel significativo que a conscientização, o treinamento e a educação } \\
\text { do público têm para alcançar o desenvolvimento sustentável. }\end{array}$ \\
\hline 成 & $\begin{array}{l}\text { 28. Estudar programas de gestão ambiental junto aos funcionários para aumentar sua compreensão sobre as questões } \\
\text { de sustentabilidade no ambiente construído ou no gerenciamento de serviços. }\end{array}$ \\
\hline 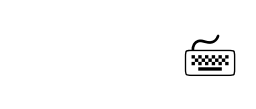 & $\begin{array}{l}\text { 29. Desenvolver uma compreensão integrada das relações estabelecidas entre os vários grupos sociais locais com o } \\
\text { meio natural e com o meio construído. }\end{array}$ \\
\hline 2,4 & 30. Compreender e abraçar a diversidade entre países e culturas. \\
\hline
\end{tabular}




\begin{tabular}{|c|c|c|}
\hline & $\approx$ & $\begin{array}{l}\text { 31. Estimular a visão complexa, abrangente e a reflexão crítica sobre problemas ambientais para uma educação } \\
\text { sistêmica e de cultura compartilhada. }\end{array}$ \\
\hline$\frac{\leftrightarrow \omega}{\sim}$ & $\checkmark$ & $\begin{array}{l}\text { 32. Estudar sobre princípios da permacultura e cradle-to-cradle e praticá-los para habitar na Terra sem destruir a } \\
\text { vida. }\end{array}$ \\
\hline$\stackrel{\substack{\frac{0}{4} \\
>}}{>}$ & 盛 & $\begin{array}{l}\text { 33. Esboçar programa com estrutura holística e perspectiva de um futuro sustentável para a escola e sua comunidade } \\
\text { para a criação de ambientes produtivos, sustentáveis e ecológicos e para promover mudança na forma como os } \\
\text { alunos percebem e interagem com o ambiente. }\end{array}$ \\
\hline
\end{tabular}


RUMOS E METAS

\begin{tabular}{|c|c|c|}
\hline & 重 & $\begin{array}{l}\text { 34. Gestão democrática de governança organizada, inclusiva e participativa do coletivo escolar, lideranças e conselho, } \\
\text { nas avaliações, decisões e execuções, com respeito à diversidade, inovação e criatividade. }\end{array}$ \\
\hline & 成 & $\begin{array}{l}\text { 35. Praticar a convivência de respeito intercultural entre diferenças, a escuta, o diálogo, mediação e arbitragem, a } \\
\text { equidade e cooperação. }\end{array}$ \\
\hline & 坥 & 36. Dedicação, colaboração, gerenciamento de tempo e trabalho em equipe. \\
\hline & 成 & $\begin{array}{l}\text { 37. Estabelecer um espaço participativo e consensual para planejamento de roteiro de projeto e execução (plano de } \\
\text { ação) voltado à sustentabilidade na escola com objetivos e metas viáveis. }\end{array}$ \\
\hline ? & 盛 & $\begin{array}{l}\text { 38. Estruturar uma coordenação de sustentabilidade - comitês, escritórios ou diretores encarregados - para conectar } \\
\text { o currículo, edificação e comunidade escolar ao plano de ação na solução de problemas complexos e discussão das } \\
\text { políticas ambientais. }\end{array}$ \\
\hline تصن & 萬 & $\begin{array}{l}\text { 39. Promover modificação holística do currículo escola, objetivos e métodos de ensino e liberdade de escolha de temas } \\
\text { transversais ao currículo segundo contextos próprios expostos por meio de uma estrutura organizacional } \\
\text { comunitária para trocas mútuas de comunicação }\end{array}$ \\
\hline & $\checkmark$ & $\begin{array}{l}\text { 40. Gestão ambiental com dupla função: melhorar a eficiência do edificio e serviços, identificando e corrigindo práticas } \\
\text { inadequadas, e envolver os alunos na EDS participativa com o monitoramento e avaliação periódicos do } \\
\text { desempenho das ações para atender questões ambientais e de sustentabilidade implementadas nos setores de água, } \\
\text { energia, materiais, alimentos, biodiversidade, resíduos ou controle de poluição na escola para que o ambiente de } \\
\text { aprendizagem física desempenhe papel central na reforma da cultura operacional da escola. }\end{array}$ \\
\hline & 国 & $\begin{array}{l}\text { 41. Divulgar, informar e envolver a comunidade escolar sobre iniciativas de sustentabilidade, experiências bem- } \\
\text { sucedidas, dificuldades ou oportunidades e criar um código de sustentabilidade da escola a partir das experiências } \\
\text { construídas. }\end{array}$ \\
\hline & $\checkmark$ & $\begin{array}{l}\text { 42. Sinalizar o compromisso administrativo da instituição com a sustentabilidade e preservação e estimular } 0 \\
\text { conhecimento da sustentabilidade por meio de ferramentas de ensino e mudanças físicas na escola para infundir }\end{array}$ \\
\hline
\end{tabular}




\begin{tabular}{|c|c|c|}
\hline & & $\begin{array}{l}\text { uma ética de responsabilidade ambiental, fiscal e social em toda a comunidade e gerar engajamento com } 0 \\
\text { desenvolvimento sustentável. }\end{array}$ \\
\hline & $\checkmark$ & $\begin{array}{l}\text { 43. Incentivar o desenvolvimento continuado reconhecendo e destacando a comunidade escolar por seus esforços de } \\
\text { sustentabilidade. }\end{array}$ \\
\hline & 盛 & $\begin{array}{l}\text { 44. Gestão de pessoas e uso de questionários regulares a funcionários ou outra avaliação para medir seu desempenho } \\
\text { como empregadora, a satisfação e o engajamento do funcionário, integrar conhecimentos, aptidões, valores, } \\
\text { atitudes e ações. }\end{array}$ \\
\hline 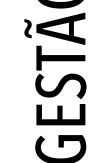 & 盛 & $\begin{array}{l}\text { 45. Gestão financeira que administra recursos para atender necessidades atuais com fundos operacionais e para } \\
\text { atender projetos futuros, com participação da comunidade escolar no planejamento e na aplicação dos recursos e } \\
\text { ampliação da transparência. }\end{array}$ \\
\hline & 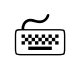 & 46. Plano-diretor prevendo expansão potencial da escola para acomodar as necessidades futuras. \\
\hline & $\checkmark$ & 47. Participar de eventos que estimulam inovações e empreendedorismo. \\
\hline & $\checkmark$ & 48. Implementar um sistema de gestão ambiental ISO 14001 é padrão internacional \\
\hline
\end{tabular}




\begin{tabular}{|c|c|c|}
\hline \multicolumn{2}{|l|}{ PREPARAR } & 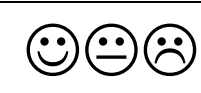 \\
\hline 更 & $\begin{array}{l}\text { 49. Elaborar o projeto político-pedagógico de forma participativa e submetido a um processo de revisão ou revalidação } \\
\text { continuados na construção de conhecimentos interdisciplinares, valores, habilidades, atitudes e competências para } \\
\text { a resolução de problemas, pesquisa aplicada, síntese de informação, saber tecnológico, além das habilidades } \\
\text { fundamentais de leitura, escrita e cálculo. }\end{array}$ & \\
\hline$\approx$ & $\begin{array}{l}\text { 50. Auxiliar os alunos a desenvolver os conhecimentos e as habilidades necessárias para serem líderes criativos e } \\
\text { autossuficientes num futuro ambiental desafiador e complexo e a cultivar a aprendizagem ao longo da vida por } \\
\text { meio de processos dinâmicos ou por mentoria, onde cada indivíduo reconheça suas potencialidades e se tornem } \\
\text { embaixadores do desenvolvimento sustentável. }\end{array}$ & \\
\hline 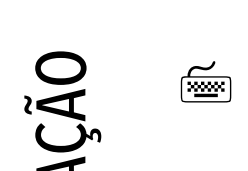 & $\begin{array}{l}\text { 51. Promover a capacitação ou formação pré-serviço e continuada em EDS de professores e profissionais da área de } \\
\text { educação (diretores, coordenadores, monitores) por meio de cursos, workshops e facilitadores que contribuam } \\
\text { para o desenvolvimento profissional desses atores. }\end{array}$ & \\
\hline $\bar{v}$ & 52. Valorizar os professores que vivenciam uma mudança pessoal em direção à sustentabilidade. & \\
\hline گे & $\begin{array}{l}\text { 53. Professores recebem tempo e assessoria para planejar a melhor forma de usar os espaços de aprendizagem da } \\
\text { escola. }\end{array}$ & \\
\hline$\checkmark$ & $\begin{array}{l}\text { 54. Permitir aos professores flexibilidade na escolha de tópicos sobre os quais tenham conhecimento para que tenham } \\
\text { domínio sobre o que é ensinado, como é ensinado, o calibre da discussão e a qualidade das atividades de } \\
\text { acompanhamento. }\end{array}$ & \\
\hline$\checkmark$ & $\begin{array}{l}\text { 55. Estabelecer como tópicos a eco-alfabetização; a permacultura; a conscientização sobre mudanças do clima ou } \\
\text { princípios básicos de organização das comunidades ecológicas para incorporá-los na vida diária e na vida da } \\
\text { comunidade. }\end{array}$ & \\
\hline 迺 & $\begin{array}{l}\text { 56. Promover uma comunidade de prática (CoP) ou fórum de participação voluntária e informal para professores e } \\
\text { profissionais da área de educação discutirem e compartilharem experiências e conhecimento na prática de EDS. }\end{array}$ & \\
\hline
\end{tabular}




\begin{tabular}{|c|c|c|}
\hline \multirow{10}{*}{ 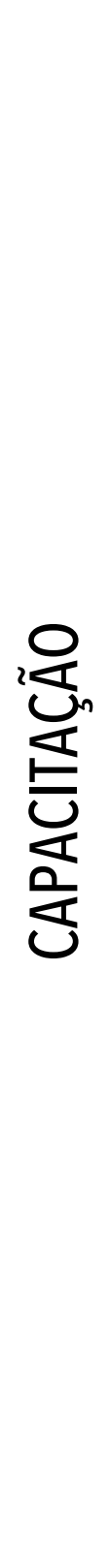 } & 盛 & $\begin{array}{l}\text { 57. A EDS como uma abordagem imperativa e uma estratégia pedagógica holística de metodologia inter, multi e } \\
\text { transdisciplinar da educação com campo participativo para o pluralismo de ideias de colaboradores, em novas } \\
\text { formas e oportunidades de ensino transversal a todas as disciplinas e na educação especial. }\end{array}$ \\
\hline & $\approx$ & 58. Promover pontes entre o saber científico moderno e o saber tradicional enraizado no repertório local. \\
\hline & 成 & $\begin{array}{l}\text { 59. Aprendizagem experiencial, por investigação e educação em valores utilizando o meio ambiente imediato do aluno } \\
\text { e do entorno da escola como recurso pedagógico para a educação; perceber demandas sobre o meio ambiente no } \\
\text { edificio escolar e comunidade local e explorá-las pedagogicamente de forma transversal às disciplinas junto à } \\
\text { gestão ambiental escolar participando da tomada de decisões. }\end{array}$ \\
\hline & & $\begin{array}{l}\text { 60. Encorajar a aprendizagem baseada em projetos práticos e motivada por uma investigação sobre problemas } \\
\text { concretos conecta o currículo da sala de aula ao mundo real do aluno seus próprios interesses: a educação sobre } \\
\text { o meio ambiente, para o meio ambiente e no meio ambiente gera impactos mais amplos em sua compreensão da } \\
\text { EDS. }\end{array}$ \\
\hline & & $\begin{array}{l}\text { 61. Ensinar a importância de práticas sustentáveis e soluções ecológicas por meio do exemplo pode envolver alunos, } \\
\text { professores e funcionários e fortalecer o currículo escolar servindo como ferramenta pedagógica ativa para a EDS. }\end{array}$ \\
\hline & (a) & $\begin{array}{l}\text { 62. Salas de aula ao ar livre são mais eficazes no fornecimento de oportunidades de aprendizagem para crianças do } \\
\text { ensino fundamental. }\end{array}$ \\
\hline & & $\begin{array}{l}\text { 63. Capacitar os alunos a se tornarem alunos ativos e participantes ativos em questões locais e globais, desenvolvendo- } \\
\text { os em habilidades e criatividade para a solução de problemas à medida que os desafios da sustentabilidade são } \\
\text { apresentados. }\end{array}$ \\
\hline & & $\begin{array}{l}\text { 64. Fomentar a alfabetização ecológica na comunidade escolar como um todo e oferecer programas ambientais na } \\
\text { escola, fornecimento de sites interativos, passeios ecológicos, cursos ou workshops em EA curtos, práticas } \\
\text { sustentáveis de forma voluntária e gratuita ou palestras sobre os Objetivos de Desenvolvimento Sustentável [ODS]. }\end{array}$ \\
\hline & (a) & 65. Incentivar alunos e funcionários a adotar ou experimentar práticas e estilos de vida sustentáveis. \\
\hline & & $\begin{array}{l}\text { 66. Fomentar o trabalho voluntário como forma de desenvolver habilidades de liderança e aprofundamento de } \\
\text { conhecimentos sobre problemas práticos reais. }\end{array}$ \\
\hline
\end{tabular}




\begin{tabular}{|c|c|}
\hline 些 & $\begin{array}{l}\text { 67. Tradução dos princípios de equidade, deferência e democracia no curriculo: alunos e adultos ouvem sobre } \\
\text { experiências, histórias, documentos, ideias, ferramentas, etc. e respondem ao contexto ambiental; todos aprendem } \\
\text { uns com os outros, e todas as formas de conhecimento são ouvidas e respeitadas. }\end{array}$ \\
\hline (a) & $\begin{array}{l}\text { 68. Capacitar administradores em habilidades técnicas e competências-chave, como pensamento sistêmico, } \\
\text { antecipação, normativa, competência estratégica e interpessoal para a gestão sustentável da escola, e funcionários } \\
\text { para preservar, conservar e gerenciar o ambiente e implementar práticas e sistemas sustentáveis. }\end{array}$ \\
\hline & $\begin{array}{l}\text { 69. Utilização pedagógica das tecnologias atuais de informação e comunicação para tarefas, pesquisa, avaliação, } \\
\text { apresentar trabalhos, desenvolver habilidades e expressão criativa e oferecer acesso à internet e equipamentos } \\
\text { eletrônicos possiveis. }\end{array}$ \\
\hline
\end{tabular}




\begin{tabular}{|c|c|c|}
\hline \multirow{8}{*}{ بே } & 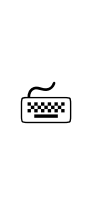 & $\begin{array}{l}\text { 70. Promover parcerias intersetoriais de partes interessadas em enfrentar os desafios da sustentabilidade num } \\
\text { ambiente multicultural e afirmativo reunindo educadores, profissionais de negócios, arquitetos, praticantes de } \\
\text { instalações escolares, defensores verdes, profissionais de energia e formuladores de politicas pode ser eficaz em } \\
\text { soluções possiveis para os problemas encontrados. }\end{array}$ \\
\hline & 成 & $\begin{array}{l}\text { 71. Coletivo multidisciplinar de profissionais habilitados convidados, preferencialmente da própria comunidade } \\
\text { escolar, é um meio de construir conhecimento, motivar a tomada de ações e melhorar a prática pela experiência } \\
\text { compartilhada, além de professores trabalhando juntos para melhorar a educação em suas próprias escolas e } \\
\text { diretores locais que se reúnem regularmente para discutir uma gestão eficaz. }\end{array}$ \\
\hline & $\approx$ & $\begin{array}{l}\text { 72. A escola e seus professores precisam estar continuamente conectados com arquitetos, profissionais de } \\
\text { sustentabilidade e outros especialistas externos da indústria e de instituições do terceiro setor para poder explorar } \\
\text { tópicos que vão da integração entre design escolar e EDS em seu currículo, à tecnologias emergentes e tendências } \\
\text { de programação educacional. }\end{array}$ \\
\hline & 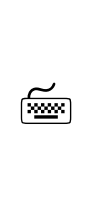 & $\begin{array}{l}\text { 73. Introduzir outras comunidades de profissionais interessados, que podem possibilitar a transferência de } \\
\text { conhecimentos e habilidades pertinentes à sustentabilidade; universidades e instituições de terceiro setor têm um } \\
\text { papel importante a desempenhar na busca do DS; profissionais de instalações da indústria desenvolveram } \\
\text { conhecimentos procedimentais que podem potencialmente beneficiar a implementação de um EMS na escola }\end{array}$ \\
\hline & $\approx$ & $\begin{array}{l}\text { 74. A EDS é interdisciplinar e deve filtrar todas as disciplinas curriculares e permear todos os aspectos da vida escolar, } \\
\text { e dessa forma a colaboração entre professores de diversas disciplinas torna-se uma prática indispensável. }\end{array}$ \\
\hline & 国 & $\begin{array}{l}\text { 75. Promover co-design: projetar uma solução para a comunidade pela comunidade incentiva os alunos a serem } \\
\text { conscientes e reflexivos, diagnosticando e aplicando soluções reais. }\end{array}$ \\
\hline & $\approx$ & $\begin{array}{l}\text { 76. Buscar suporte especializado para a construção de escola ou a análise sobre a viabilidade de intervenções } \\
\text { arquitetônicas sustentáveis em edificações existentes a partir de adequações identificadas como prioritárias. }\end{array}$ \\
\hline & $\approx$ & $\begin{array}{l}\text { 77. Solicitar avaliação ambiental do solo local e remediação, caso contamidado, atender prioridades ambientais } \\
\text { geograficamente específicas e buscar soluções inteligentes para mitigar e melhorar as condições ambientais } \\
\text { identificadas. }\end{array}$ \\
\hline
\end{tabular}




\begin{tabular}{|c|c|c|}
\hline & $\approx$ & 78. Promover a difusão de tecnologias sociais de adaptação às mudanças climáticas. \\
\hline & $\approx$ & $\begin{array}{l}\text { 79. Priorizar projetos arquitetônicos bioclimáticos, que adotam estratégias passivas para solucionar o conforto } \\
\text { térmico e luminoso dos edificios escolares e corroboram com a busca contínua por soluções para os desafios locais } \\
\text { e globais; que reutilizam estruturas existentes, planejam vários usos para as instalaçôes e melhoram o design e a } \\
\text { organização do prédio escolar com arranjos espaciais voltados ao bom desempenho de suas funçôes; que adotam } \\
\text { sistemas e materiais de construção adequados aos biomas, climas, materiais, paisagens e culturas locais. }\end{array}$ \\
\hline & $\widetilde{\alpha . ~}$ & $\begin{array}{l}\text { 80. Espaços educacionais devem ser analisados e desenvolvidos holisticamente para serem atraentes, estimulantes e } \\
\text { colaborarem com diversos estilos e oportunidades de aprendizagem para uma cultura sustentável. }\end{array}$ \\
\hline & 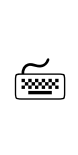 & $\begin{array}{l}\text { 81. Buscar recursos de design arquitetônico para espaços de aprendizagem que representem visivelmente a } \\
\text { sustentabilidade e gerem conexão com o mundo natural para aproximar a criança da natureza e nela estimular } \\
\text { atitudes pró-ambientais. }\end{array}$ \\
\hline صب & $\simeq$ & $\begin{array}{l}\text { 82. Tornar edificações referências de sustentabilidade socioambiental onde o design dos espaços de aprendizagem } \\
\text { permita atividades educativas múltiplas e versáteis e a arquitetura dos espaços de aprendizagem sejam projetados } \\
\text { para atender a sustentabilidade e refletir valores pró-ambientais, criando melhores ambientes de aprendizagem } \\
\text { ao desempenhar um papel pedagógico na alfabetização ambiental e contribuir para maiores níveis de envolvimento } \\
\text { escolar. }\end{array}$ \\
\hline & 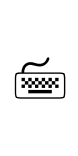 & $\begin{array}{l}\text { 83. Projetos para teaching green buildings (TGB) exigem amplos conhecimentos em sustentabilidade para resultar em } \\
\text { alta performance de conservação de água e energia e desempenho sustentável de sua construção segundo suas } \\
\text { dimensões técnicas e socioculturais. }\end{array}$ \\
\hline & $\stackrel{\sim}{\simeq}$ & $\begin{array}{l}\text { 84. A envoltória do edificio é um componente de projeto que demanda especificações a favor da qualidade do ar interior, } \\
\text { conforto e eficiência energética; integrar os espaços interiores e exteriores, maximizar a iluminação natural e } \\
\text { minimizar ganho de calor e ofuscamento com elementos de design, como prateleiras de luz e dimensionamento e } \\
\text { posicionamento adequados das janelas, orientação e aumento do perimetro do edificio e dispositivos de } \\
\text { sombreamento devem ser considerados. }\end{array}$ \\
\hline & $\approx$ & $\begin{array}{l}\text { 85. Planejar caminhos de ventilação natural segundo zonas de alta e baixa pressão para manter limpa a qualidade do } \\
\text { ar de forma passiva e sem geração de ruídos. }\end{array}$ \\
\hline
\end{tabular}




\begin{tabular}{|c|c|c|}
\hline \multirow{12}{*}{ 부뭄 } & $\approx$ & $\begin{array}{l}\text { 86. Solicitar análise da qualidade do ar interno e, se necessário condicionamento do ar, adotar sistemas HVAC \& } \mathrm{R} \\
\text { que minimizam o impacto direto na redução da camada de ozônio e nas mudanças climáticas. }\end{array}$ \\
\hline & 幽 & $\begin{array}{l}\text { 87. Análise do desempenho acústico, seja nos tetos para controle de ruído e reverberação sonora com materiais } \\
\text { absorventes de som adequados, seja para detectar caminhos de ruído como dutos, estruturas e equipamentos ou } \\
\text { adjacências. }\end{array}$ \\
\hline & 幽 & $\begin{array}{l}\text { 88. Solicitar cálculos de simulação para maximizar o conforto acústico, térmico e luminoso no projeto arquitetônico } \\
\text { de forma passiva com redução do consumo energético. }\end{array}$ \\
\hline & $\approx$ & $\begin{array}{l}\text { 89. Solicitar desenho arquitetônico para edificações dotadas de conforto térmico prevendo recursos como janelas } \\
\text { operáveis, vidros, materiais de qualidade para isolamentos de coberturas ou para radiação do calor para o interior, } \\
\text { conforme o clima local. }\end{array}$ \\
\hline & $\approx$ & $\begin{array}{l}\text { 90. Soluções de eficiência energética em relação ao projeto e construção incluem especificações de equipamentos e } \\
\text { especificação de luminárias eficientes para complementar a luz do dia disponível. }\end{array}$ \\
\hline & $\approx$ & $\begin{array}{l}\text { 91. Solicitar análise do cilco de vida para o projeto do edificio escolar para prever custos da sua construção e operações } \\
\text { ao longo da sua vida, demolição, incluindo reciclagem e descarte. }\end{array}$ \\
\hline & 幽 & 92. Sempre que possível adotar a eco-construção visando o menor impacto de implantação, canteiro e materiais. \\
\hline & 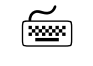 & 93. Avaliar o potencial de energia renovável local e buscar aplicar tecnologias limpas. \\
\hline & $\cong$ & 94. Priorizar o design para adaptabilidade de pessoas com necessidades educacionais especiais. \\
\hline & $\checkmark$ & $\begin{array}{l}\text { 95. Apoiar empresas preferencialmente locais comprometidas com a comunidade local, com a sustentabilidade e } \\
\text { balizadas em valores sociais e ambientais. }\end{array}$ \\
\hline & $\checkmark$ & 96. Fomentar e reportar sobre empregos verdes como caminho para a sustentabilidade. \\
\hline & $\checkmark$ & 97. Promover o patrimônio cultural e natural locais. \\
\hline
\end{tabular}


98. Aumentar os canais de comunicação para fortalecer a conexão e o diálogo entre escolas situadas em contextos diferentes e diversos - socioeconômicos, geográficos, culturais para compreender os desafios da sustentabilidade juntos e compartilhar ideias, histórias, problemas, trabalhos, projetos, conhecimentos. 


\begin{tabular}{|c|c|c|c|}
\hline & & & 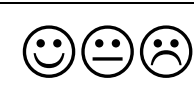 \\
\hline & $\approx$ & $\begin{array}{l}\text { 99. Adotar o espaço físico escolar como uma ferramenta de ensino para promover a apreciação e compreensão do } \\
\text { design sustentável e oferecer uma variedade de oportunidades de aprendizagem de livre escolha para temas de } \\
\text { sustentabilidade, onde o aprendizado e a ação ambiental acontecem dentro e fora da sala de aula. }\end{array}$ & \\
\hline & $\approx$ & $\begin{array}{l}\text { 100. Ensinar aos alunos a importância da inovação no ambiente construído, seja pelo uso de materiais } \\
\text { tradicionalmente adotados pela população local ou técnicas sofisticadas de alta tecnologia. }\end{array}$ & \\
\hline & $\checkmark$ & $\begin{array}{l}\text { 101. Fornecer ar limpo e fresco que geram conforto térmico, luz natural abundante, baixa distração com ruídos } \\
\text { indesejados, qualidade acústica, eficiência energética, segurança pessoal e mínima poluição são diretrizes básicas } \\
\text { na ES. }\end{array}$ & \\
\hline 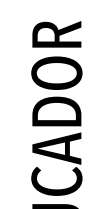 & $\approx$ & $\begin{array}{l}\text { 102. Ambientes construídos que integram à paisagem natural e o patrimônio cultural locais são benéficos para a } \\
\text { aprendizagem e são especialmente adequados para EDS; lugares onde os alunos vivenciam o desenvolvimento } \\
\text { sustentável, espaços em que a energia e a transição ecológica, a emergência de novos estilos de vida, a } \\
\text { solidariedade local e internacional se tornem uma realidade. }\end{array}$ & \\
\hline Un & $\approx$ & $\begin{array}{l}\text { 103. ES apresentam uma concepção de ambiente em sua totalidade, considerando a interdependência sistêmica } \\
\text { entre o meio natural e o construído, o socioeconômico, o cultural, a trajetória histórica, o espiritual, sob o enfoque } \\
\text { da sustentabilidade e considerando as especificidades territoriais; apresentam boa temperatura, cores adequadas, } \\
\text { mobília confortável, visão para fora, liberdade para me mover e permite escolher onde trabalhar, proporcionam } \\
\text { um ambiente saudável, confortável, seguro, protegido e estimulante que ensinam práticas sustentáveis. }\end{array}$ & \\
\hline & $\approx$ & $\begin{array}{l}\text { 104. A ES é uma intersecção entre arquitetura e EA e têm muito potencial para transmitir uma ética geral de } \\
\text { sustentabilidade pela facilidade de identificação visual de recursos; monitores de feedback de energia, jardins, } \\
\text { programas de reciclagem, bicicletários ou painéis fotovoltaicos alguns são exemplos. }\end{array}$ & \\
\hline & $\approx$ & $\begin{array}{l}\text { 105. Parques e espaços exteriores e de lazer da escola são utilizados para aprendizagem como salas de aula; jardim } \\
\text { escolar e entorno arborizado e ajardinado para proporcionar melhores condições de aprendizagem e de convívio } \\
\text { social. }\end{array}$ & \\
\hline & $\approx$ & $\begin{array}{l}\text { 106. Áreas de lazer e recreação ao ar livre para possibilitar a convivência da comunidade escolar ou mais ampla, } \\
\text { com elementos naturais e culturais, propiciar vivências, sensações, interações, onde o ambiente fisico de } \\
\text { aprendizagem ocorre sob contexto social e individual em processos formal e informal. }\end{array}$ & \\
\hline
\end{tabular}




\begin{tabular}{|c|c|c|}
\hline & $\checkmark$ & $\begin{array}{l}\text { 107. Centro de sustentabilidade com criação de animais, galinheiro, horta, cultivo de plantas e compostagem é } \\
\text { incorporado como espaço educativo. }\end{array}$ \\
\hline & 픘 & 108. Pavimentação permeável e pisos exteriores de cores claras no lugar de asfalto. \\
\hline & 唡 & 109. Uso das ecotécnicas para apropriação pedagógica. \\
\hline & 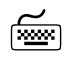 & 110. Portas, torneiras e banheiros sem toque. \\
\hline ᄋ్ & 풌 & $\begin{array}{l}\text { 111. } 0 \text { aproveitamento máximo da luz do dia na edificação escolar tem uma associação positiva e altamente } \\
\text { significativa com a melhoria do desempenho do aluno por manter ritmos circadianos de crianças e ciclos de sono } \\
\text { saudáveis, além de minimizar o impacto ambiental da edificação por permitir o aquecimento radiante passivo, } 0 \\
\text { que demanda a adequada orientação solar do edificio e de suas aberturas e cuidados para não causar desconforto } \\
\text { térmico e ofuscamento. }\end{array}$ \\
\hline & $\approx$ & 112. A iluminação artificial é complementar, mas de alta eficiência energética. \\
\hline$\Theta_{n}$ & 풌 & $\begin{array}{l}\text { 113. Ambientes pedagógicos da ES apresentam forros acústicos e conforto acústico necessário para isolar ruídos } \\
\text { externos e escutar bem o professor e alunos. }\end{array}$ \\
\hline 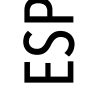 & 풌 & $\begin{array}{l}\text { 114. Sistemas de controle térmico, de iluminação ambiente e sobre as janelas, segundo as preferências dos } \\
\text { ocupantes. }\end{array}$ \\
\hline & $\approx$ & $\begin{array}{l}\text { 115. Vistas abertas para o exterior em corredores ou outros ambientes no edifício são positivas e altamente } \\
\text { significativas para o desempenho dos alunos. }\end{array}$ \\
\hline & 풌 & $\begin{array}{l}\text { 116. } 0 \text { caminho natural das correntes de ar nos ambientes promove o equilíbrio térmico quando atendidas as taxas } \\
\text { ideais de ventilação e conforto. }\end{array}$ \\
\hline & 풌 & $\begin{array}{l}\text { 117. Os materiais construtivos são preferencialmente naturais e locais, ambientalmente corretos, adaptados às } \\
\text { condições climáticas, em conformidade com seu uso construtivo e de fácil aceitação pela comunidade. }\end{array}$ \\
\hline & $\approx$ & $\begin{array}{l}\text { 118. A sala de aula tem acesso direto a espaços externos, espaço de descanso, espaços para várias possibilidades } \\
\text { de aprendizagem: trabalho em grupo colaborativo, trabalho de projeto ou trabalho individual. }\end{array}$ \\
\hline
\end{tabular}




\begin{tabular}{|c|c|c|}
\hline \multirow{12}{*}{ 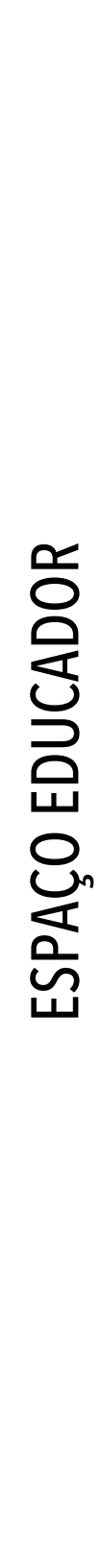 } & 풌 & $\begin{array}{l}\text { Espaços dinâmicos de aprendizagem com flexibilidade de layouts para métodos de trabalho individual, em pares } \\
\text { e em grupo apoiam a apresentação e o trabalho individual, a aprendizagem em pequenos grupos e dois ou mais } \\
\text { professores ensinando em equipe com pequenos grupos de alunos; as cadeiras e mesas são confortáveis, ajustáveis } \\
\text { em suas alturas, para que fiquem ergonômicas e podem ser facilmente reorganizados antes ou durante a aula. }\end{array}$ \\
\hline & $\approx$ & $\begin{array}{l}\text { 120. Uma variedade de espaços bem equipados de diferentes tamanhos conectados que apoiam múltiplos e diversos } \\
\text { programas e pedagogias de ensino e aprendizagem: espaço de oficina, estúdio para arte, música ou design, uma } \\
\text { cozinha/ espaço de tecnologia alimentar, um espaço de oficina de tecnologias de materiais. }\end{array}$ \\
\hline & $\checkmark$ & $\begin{array}{l}\text { 121. Espaço tranquilo para professores socializarem e conversarem com outros funcionários/ professores antes ou } \\
\text { depois das aulas. }\end{array}$ \\
\hline & $\approx$ & $\begin{array}{l}\text { 122. Os telhados verdes operam no gerenciamento do escoamento de águas pluviais e na mediação do ganho de calor } \\
\text { solar; regulam a umidade do ar e minimizam ilhas de calor assim como a presença de árvores nativas ou adaptadas, } \\
\text { grandes arbustos, treliças com vegetação e a pavimentação permeável. }\end{array}$ \\
\hline & $\approx$ & 123. As áreas de alimentação são preferencialmente ao ar livre ou abertas para o exterior. \\
\hline & $\approx$ & $\begin{array}{l}\text { 124. As edificações na ES são acessiveis para pessoas com deficiência, mobilidade comprometida ou necessidades } \\
\text { especiais. }\end{array}$ \\
\hline & $\approx$ & $\begin{array}{l}\text { 125. Adoção preferencialmente de produtos pré-fabricados, pré-montados e modulados, que reduzem perdas e } \\
\text { desperdício. }\end{array}$ \\
\hline & $\approx$ & 126. 0 conforto térmico, luminoso, olfativo e a acuidade visual estão equalizados em todos os ambientes de ensino. \\
\hline & $\approx$ & 127. Tecnologias, modernas ou tradicionais estão integradas ao espaço. \\
\hline & $\approx$ & 128. Sistema fotovoltaico ou outros sistemas de geração de energia estão presentes. \\
\hline & 풌 & $\begin{array}{l}\text { 129. Sistema aparente de aproveitamento de água da chuva, da sua coleta em coberturas ao seu armazenamento } \\
\text { em cisterna; calculadora de água da chuva para as crianças medirem a quantidade de água economizada. }\end{array}$ \\
\hline & $\checkmark$ & 130. Comunicados de mensagens pró-ambientais estão por toda a escola. \\
\hline
\end{tabular}




\begin{tabular}{|c|c|c|c|}
\hline \multicolumn{3}{|c|}{ AÇÃO } & 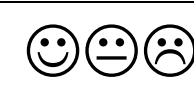 \\
\hline \multirow{12}{*}{ 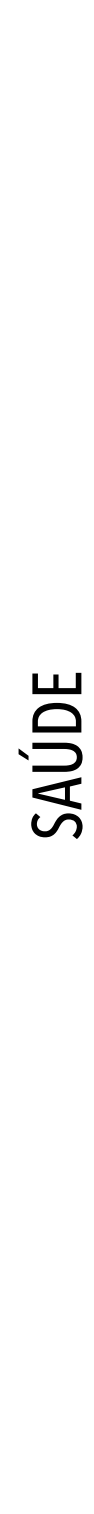 } & $\checkmark$ & 131. Promover a paz. & \\
\hline & $\checkmark$ & $\begin{array}{l}\text { 132. Promover a saúde por meio da melhoria do ambiente e da qualidade de vida das pessoas e na escola e seu } \\
\text { entorno. }\end{array}$ & \\
\hline & (8) & $\begin{array}{l}\text { 133. Ajudar alunos e professores a se manterem saudáveis de corpo, mente e espírito, estimulam passar tempo na } \\
\text { natureza ou ar livre e investigáa a relação entre a saúde e bem-estar das comunidades locais e o meio ambiente. }\end{array}$ & \\
\hline & 2,4 & $\begin{array}{l}\text { 134. Oferecer comida saudável, refeições com alimentos de base vegetal de baixo impacto ambiental, alimentos e } \\
\text { bebidas à base de vegetais cultivados na horta da escola ou produzidos de forma sustentável e ética promove a } \\
\text { segurança alimentar, favorece a preservação da biodiversidade na agricultura de alimentos orgânicos e melhores } \\
\text { condições aos trabalhadores agrícolas, solos e hidrovias mais saudáveis. }\end{array}$ & \\
\hline & $\checkmark$ & 135. Cultivar pomar de árvores frutíferas que podem complementar as necessidades nutricionais das escolas. & \\
\hline & $\checkmark$ & $\begin{array}{l}\text { 136. Cultivar espiral de ervas e plantas medicinais que podem ser usadas em remédios caseiros em práticas } \\
\text { tradicionais de saúde. }\end{array}$ & \\
\hline & $\checkmark$ & $\begin{array}{l}\text { 137. Garantir a qualidade sanitária dos ambientes, do ar e da água; medidas sanitárias e de hábitos de higiene } \\
\text { pessoal para garantia de saúde, segurança e bem-estar coletivo e do ambiente. }\end{array}$ & \\
\hline & $\checkmark$ & 138. Facilitar uso dos serviços e instalações de água e saneamento por todos os usuários potenciais do edifício. & \\
\hline & $\checkmark$ & 139. Eliminar focos de empoçamentos ou água parada em pisos, coberturas ou calhas. & \\
\hline & $\checkmark$ & $\begin{array}{l}\text { 140. Promover o trabalho seguro e socialmente responsável, uso obrigatório de equipamentos de proteção individual } \\
\text { (EPI), e prevenir doenças ocupacionais aos funcionários. }\end{array}$ & \\
\hline & $\checkmark$ & 141. Os ambientes são livres de cigarro dentro da escola e entorno, por proibição. & \\
\hline & $\simeq$ & $\begin{array}{l}\text { 142. Garantir a especificação de materiais de acabamento usados em construções e equipamentos não poluentes } \\
\text { e/ou com reduzida toxidade. Uso de tintas minerais ecológicas a base de terra crua }\end{array}$ & \\
\hline
\end{tabular}




\begin{tabular}{|c|c|c|}
\hline & $\approx$ & 143. Os níveis de formaldeído nas ES devem ser mantidos muito baixos ou nulos. \\
\hline & $\checkmark$ & 144. Eliminar materiais ou produtos que representam um risco de contaminação. \\
\hline & $\checkmark$ & 145. Os materiais de limpeza não devem ser tóxicos, perigosos ou deixar resíduos no ambiente. \\
\hline & $\checkmark$ & $\begin{array}{l}\text { 146. As áreas verdes são manejadas organicamente, sem o uso de fertilizantes inorgânicos e pesticidas químicos, } \\
\text { fungicidas e herbicidas. }\end{array}$ \\
\hline 2 & 뜼 & 147. Reduzir a potencial presença de mofo nas escolas por meio de medidas preventivas de projeto e construção \\
\hline & $\checkmark$ & 148. Ventilação é a alternativa eficaz para eliminar CO2 do ar interior gerado pelos ocupantes. \\
\hline & $\checkmark$ & 149. Banimento do uso de materiais cuja matéria-prima é o amianto. \\
\hline & $\checkmark$ & 150. Uso de lâmpadas isentas de mercúrio ou preferencialmente LED. \\
\hline & $\checkmark$ & $\begin{array}{l}\text { 151. A proteção e segurança deve ser garantida em todos os espaços da escola em relação a acidentes ou qualquer } \\
\text { tipo de perigo. }\end{array}$ \\
\hline
\end{tabular}




\begin{tabular}{|c|c|c|c|}
\hline \multicolumn{3}{|c|}{ AÇÃO } & $\ddot{\theta} \odot \ddot{\theta}$ \\
\hline \multirow{9}{*}{ 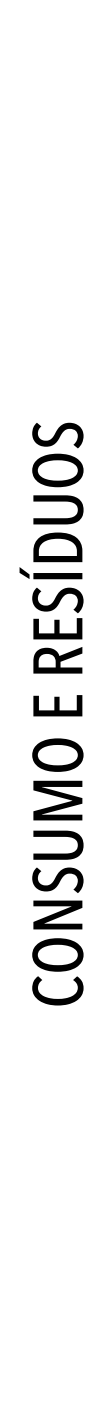 } & $\approx$ & $\begin{array}{l}\text { 152. Sistema escolar de gestão de resíduos sólidos e orgânicos prevendo minimização da produção de resíduos, } \\
\text { redução de emissões poluentes e do uso de recursos não renováveis, melhoria dos serviços e sistemas de limpeza, } \\
\text { distribuição de lixeiras seletivas para segregação dos diversos resíduos, procedimentos de coleta, armazenamento } \\
\text { e destinação corretas, compostagem de resíduos orgânicos, apoio à reciclagem de resíduos secos. }\end{array}$ & \\
\hline & 24 & 153. Compreensão das causas dos hábitos consumistas e agir para a transformação dos sistemas que os sustentam. & \\
\hline & & 154. Não compra se não for necessário. & \\
\hline & & $\begin{array}{l}\text { 155. Os 5R: repensar hábitos de consumo; recusar produtos danosos ao meio ambiente ou à saúde; reduzir a geração } \\
\text { de lixo; reutilizar sempre que possível; reciclar, transformando em um novo produto. }\end{array}$ & \\
\hline & 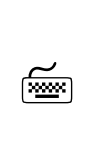 & $\begin{array}{l}\text { 156. } 0 \text { plano de gerenciamento de resíduos de construção civil e demolição envolve conscientização dos recursos } \\
\text { naturais, matérias-primas e emissões poluentes neles agregados e exige segregação e isolamento em área do } \\
\text { canteiro de obras dos materiais para reciclagem, reutilização ou descarte correto. }\end{array}$ & \\
\hline & $\simeq$ & $\begin{array}{l}\text { 157. Promover a importância da economia circular e da reciclabilidade dos produtos derivados da madeira e } \\
\text { incorpora ao projeto de construção materiais recuperados, com conteúdo reciclado, de origem local, de fontes } \\
\text { renováveis, madeira certificada por fornecedores comprometidos. }\end{array}$ & \\
\hline & (8) & $\begin{array}{l}\text { 158. Possuir programa de reutilização, recuperação e reciclagem na comunidade escolar de produtos ou materiais, } \\
\text { incluindo os de construção, como meio de reduzir o lixo dentro e ao redor da escola. }\end{array}$ & \\
\hline & (9) & $\begin{array}{l}\text { 159. Buscar taxas de participação altas no descarte seletivo consciente e correto, no tratamento de resíduos sólidos } \\
\text { por meio da reutilização e reciclagem e da compostagem para os resíduos alimentares, criando uma cultura da } \\
\text { prática estética do cuidado com o ambiente e a paisagem, em toda a escola, da sala de aula às operações e } \\
\text { administração, da secretaria ao refeitório. }\end{array}$ & \\
\hline & $\approx$ & $\begin{array}{l}\text { 160. Evitar o descarte em aterros sanitários e instalações de incineração de resíduos químicos perigosos à } \\
\text { programas de reciclagem; verificar procedimentos junto ao fabricante. }\end{array}$ & \\
\hline
\end{tabular}




\begin{tabular}{|c|c|c|}
\hline \multirow{4}{*}{$\frac{\tilde{0}}{\frac{\mathfrak{\theta}}{\tilde{n}}}$} & $\checkmark$ & $\begin{array}{l}\text { 161. O desperdício de todo tipo, incluindo alimentos, onera o ambiente e a escola e deve ser evitado; sobras de } \\
\text { alimentos ainda saudáveis podem ser compartilhadas, reaproveitadas ou consumidas posteriormente. }\end{array}$ \\
\hline & $\checkmark$ & $\begin{array}{l}\text { 162. A compostagem por minhocário dos resíduos orgânicos vegetais nutrem a horta escolar num ciclo virtuoso } \\
\text { com a participação da comunidade. }\end{array}$ \\
\hline & $\stackrel{\sim}{\simeq}$ & $\begin{array}{l}\text { 163. Atender à logistica reversa de produtos sempre que possivel, que prevê o retorno do resíduo gerado por } \\
\text { determinado produto ao seu produtor ou o processamento por empresas recicladoras, especialmente na destinação } \\
\text { e descontaminação adequada de lâmpadas, pilhas, baterias e aparelhos eletrônicos. }\end{array}$ \\
\hline & $\checkmark$ & $\begin{array}{l}\text { 164. Programa para transformar o óleo de cozinha em sabão, destinado ao uso pela própria escola ou pelas famílias } \\
\text { dos estudantes. }\end{array}$ \\
\hline & $\checkmark$ & $\begin{array}{l}\text { 165. Reduzir o consumo de materiais em geral e de papel por meio de equipamentos eletrônicos ou outros recursos, } \\
\text { reduzir ou eliminar materiais descartáveis ou materiais que tenham embalagens desnecessárias. }\end{array}$ \\
\hline & $\checkmark$ & 166. Comprar papel de escritório somente com conteúdo reciclado e certificado. \\
\hline & $\checkmark$ & $\begin{array}{l}\text { 167. Comprar produtos e serviços de comércio justo e preferencialmente de negócios comunitários ou empresas } \\
\text { locais que promovem aspectos da sustentabilidade. }\end{array}$ \\
\hline & $\checkmark$ & $\begin{array}{l}\text { 168. Compra de produtos, serviços e da agricultura familiar locais para minimizar impactos ambientais e favorecer } \\
\text { o pequeno negócio, prevalecendo a produção de alimentos em horta local. }\end{array}$ \\
\hline & $\checkmark$ & 169. Comprar materiais e equipamentos duráveis, eficientes, de baixo consumo energético e de água. \\
\hline
\end{tabular}




\begin{tabular}{|c|c|c|c|}
\hline \multicolumn{3}{|c|}{ AÇÃO } & 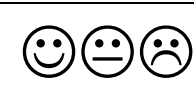 \\
\hline \multirow{10}{*}{ 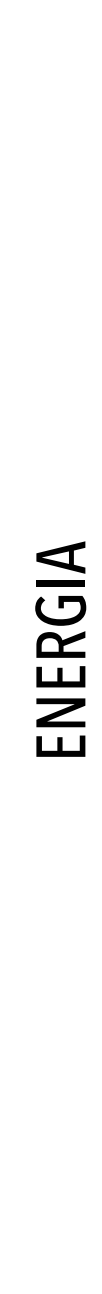 } & 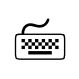 & 170. Gestão eficiente do consumo de energia. & \\
\hline & $\approx$ & $\begin{array}{l}\text { 171. Realizar medição do desempenho energético do edificio escolar para controlar e otimizar a sua eficiência } \\
\text { energética. }\end{array}$ & \\
\hline & $\checkmark$ & $\begin{array}{l}\text { 172. Comprar equipamentos com o selo PROCEL (Programa de Conservação de Energia, da Eletrobras), que garante } \\
\text { aumento da eficiência energética mantendo baixo o consumo dos sistemas. }\end{array}$ & \\
\hline & $\approx$ & 173. Adotar sistemas de gerenciamento de energia personalizados como interruptores individualizados. & \\
\hline & $\checkmark$ & 174. Comprar lâmpadas eficientes de alto rendimento luminoso com baixo consumo energético. & \\
\hline & $\checkmark$ & $\begin{array}{l}\text { 175. Conservar energia nos sistemas de iluminação, ventilação, aquecimento ou refrigeração por meio de } \\
\text { dispositivos como termostatos, sensores de movimento ou de presença e fotocélulas. }\end{array}$ & \\
\hline & $\approx$ & $\begin{array}{l}\text { 176. Apoiar o desenvolvimento de sistemas de energia alternativa e produzir a própria energia elétrica a partir de } \\
\text { uma ou mais fontes renováveis locais disponiveis, seja solar, eólica, geotérmica, hidrelétrica de baixo impacto, } \\
\text { biomassa e biogás. }\end{array}$ & \\
\hline & $\approx$ & $\begin{array}{l}\text { 177. Apoiar a utilização da energia solar ao adotar um fogão solar para preparo de alimentos e em aquecedores } \\
\text { solares para produção de água quente em vestiários e cozinhas. }\end{array}$ & \\
\hline & $\checkmark$ & 178. Prevalecer a iluminação natural solar sobre a artificial em todos os ambientes da escola. & \\
\hline & $\approx$ & $\begin{array}{l}\text { 179. Adotar recursos passivos da arquitetura bioclimática com dispositivos e materiais próprios para } \\
\text { sombreamento e isolamento térmico, o que reduz drasticamente as necessidades de aquecimento e refrigeração } \\
\text { elevando o desempenho energético do edificio. }\end{array}$ & \\
\hline
\end{tabular}




\begin{tabular}{|c|c|c|c|}
\hline \multicolumn{3}{|c|}{ AÇÃO } & \multirow[t]{2}{*}{ 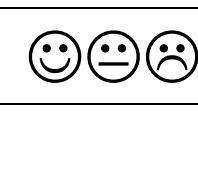 } \\
\hline \multirow{11}{*}{ 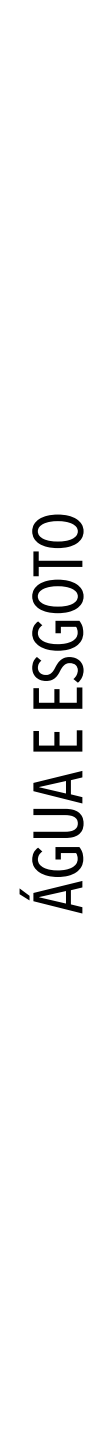 } & $\checkmark$ & 180. Não poluir ou desperdiçar água. & \\
\hline & $\checkmark$ & 181. A rede de água potável é acessivel a todos os usuários da escola como direito básico. & \\
\hline & $\checkmark$ & 182. As instalações de saneamento funcionais são separadas para homens e mulheres. & \\
\hline & $\approx$ & $\begin{array}{l}\text { 183. Gestão de águas pluviais prevendo a sua captação, armazenamento e reuso, a sua infiltração natural } \\
\text { hidrológica para reduzir contaminação, erosões em canais e sobrecarga na infraestrutura pública. }\end{array}$ & \\
\hline & $\checkmark$ & $\begin{array}{l}\text { 184. Respeitar e preservar os fluxos naturais das águas pluviais, promovendo a infiltração, minimizando ou } \\
\text { substituindo superficies impermeáveis por pavimentações permeáveis, preservando árvores e espaços verdes que } \\
\text { contribuem para a absorção, e recarga de aquíferos. }\end{array}$ & \\
\hline & $\checkmark$ & 185. Eliminar o uso de água potável em paisagismo. & \\
\hline & $\approx$ & $\begin{array}{l}\text { 186. Promover uma infraestrutura verde: bioretenção, jardins pluviais, telhados com vegetação, barris de chuva e } \\
\text { pavimentos permeáveis. }\end{array}$ & \\
\hline & $\checkmark$ & $\begin{array}{l}\text { 187. Plantar espécies endêmicas e tolerantes à seca, agrupando as plantas de acordo com suas necessidades de } \\
\text { irrigação. }\end{array}$ & \\
\hline & $\approx$ & $\begin{array}{l}\text { 188. Valorizar a água da chuva como um recurso para a redução do consumo de água servida pela rede pública } \\
\text { municipal construindo um sistema para coleta nas coberturas, retenção em telhados verdes, armazenamento em } \\
\text { cisternas, tratamento para descontaminação, distribuição em tubulação exclusiva e identificada para as descargas } \\
\text { de bacias sanitárias e mictórios, irrigação de jardim, de hortas e lavagem de pisos. }\end{array}$ & \\
\hline & $\checkmark$ & $\begin{array}{l}\text { 189. A água condensada pelo ar-condicionado e coletada pelos seus próprios drenos também pode ser uma fonte } \\
\text { alternativa. }\end{array}$ & \\
\hline & 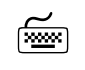 & 190. Gestão integrada de água e esgoto. & \\
\hline
\end{tabular}




\begin{tabular}{|c|c|c|}
\hline \multirow{3}{*}{ 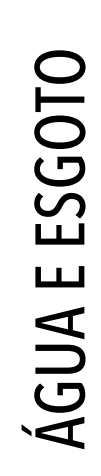 } & $\approx$ & $\begin{array}{l}\text { 191. Adotar dispositivos de economia e eficiência no uso da água, como torneiras de fechamento automático ou por } \\
\text { sensor de movimento, válvulas de descarga de baixo fluxo para bacias sanitárias de volume reduzido, válvulas de } \\
\text { fechamento automático nos mictórios, chuveiros e metais de baixo fluxo de água, arejador para torneiras e } \\
\text { restritores de vazão de água em torneiras de jardim e de lavagem. }\end{array}$ \\
\hline & $\approx$ & $\begin{array}{l}\text { 192. Usar a água de maneira responsável, sem desperdiçar, reduzir os volumes de águas residuais e garantir o seu } \\
\text { tratamento por meio de filtro biológico. }\end{array}$ \\
\hline & $\approx$ & $\begin{array}{l}\text { 193. Sistemas de saneamento mais inteligentes para esgoto, com redução da demanda de água potável, adotando } \\
\text { princípios de decomposição e purificação biológica. }\end{array}$ \\
\hline
\end{tabular}




\begin{tabular}{|c|c|c|c|}
\hline \multicolumn{3}{|c|}{ AÇÃO } & \multirow[t]{2}{*}{ 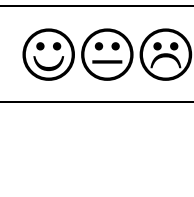 } \\
\hline \multirow{12}{*}{$\frac{\sum}{\frac{\Sigma}{\pi}}$} & ب. & 194. Conservar as espécies e seus habitats. & \\
\hline & & $\begin{array}{l}\text { 195. Identificar ecossistemas locais, espécies e habitats em estado de vulnerabilidade ou danificados, contribuir } \\
\text { para proteger a sua integridade, para restaurá-los e para mantê-los saudáveis e para promover a biodiversidade. }\end{array}$ & \\
\hline & $\checkmark$ & 196. Proteger árvores existentes e plantar espécies nativas do bioma local. & \\
\hline & $\checkmark$ & $\begin{array}{l}\text { 197. Contribuir para recuperar o microclima original local e áreas degradadas ou contaminadas ao seu estado } \\
\text { natural. }\end{array}$ & \\
\hline & $\approx$ & 198. Gestão sustentável da paisagem e da biodiversidade. & \\
\hline & 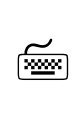 & $\begin{array}{l}\text { 199. Estruturar as áreas verdes com jardins educacionais, intensificação da arborização, plantio de alimentos, } \\
\text { viveiro de plantas, trilhas, mirantes, parques, áreas de lazer e recreação que tornem o terreno verde. }\end{array}$ & \\
\hline & $\checkmark$ & $\begin{array}{l}\text { 200. Incorporar a sala de aula viva: padrões, microclimas, solos, água, chuvas, flores e vegetais, alimento e nutrição, } \\
\text { insetos, répteis, anfíbios, pássaros, animais, ecossitemas, árvores, sol, polinização, vento, ar, atmosfera, bio- } \\
\text { indicadores. }\end{array}$ & \\
\hline & $\checkmark$ & $\begin{array}{l}\text { 201. Prevalecer as plantas nativas/ adaptadas, que requerem irrigação mínima ou nenhuma irrigação e baixa } \\
\text { manutenção. }\end{array}$ & \\
\hline & $\sim$ & $\begin{array}{l}\text { 202. Buscar aumentar a área vegetada da escola para além do exigido pela legislação, ainda que por meio de tetos } \\
\text { verdes nas coberturas. }\end{array}$ & \\
\hline & $\approx$ & 203. Adotar a calçada verde. & \\
\hline & 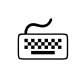 & Adotar serviços ecossistêmicos com vistas à promoção e conservação da biodiversidade dentro da escola. & \\
\hline & $\checkmark$ & 205. Aproveitar a topografia natural do terreno para drenagens e evitar impactar a paisagem. & \\
\hline
\end{tabular}


206. Prevenir a poluição e erosão com proteção da camada superficial do solo, em circunstâncias de risco, obras civis ou transportes pesados. 


\begin{tabular}{|c|c|c|c|}
\hline \multicolumn{3}{|c|}{ AÇÃO } & $\ddot{\theta} \odot \ddot{\theta}$ \\
\hline \multirow{8}{*}{ 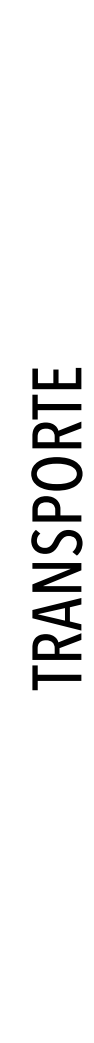 } & 24 & 207. Compor sua frota de veículos com baixo consumo e de combustiveis mais limpos. & \\
\hline & $\checkmark$ & 208. Controlar acesso e minimizar o tamanho do estacionamento. & \\
\hline & $\checkmark$ & 209. Propor otimizar o uso de estacionamentos vizinhos compartilhados. & \\
\hline & $\approx$ & $\begin{array}{l}\text { 210. Estimular o uso de bicicletas e oferecer instalações e dimensionamentos normatizados para bicicletários } \\
\text { seguros. }\end{array}$ & \\
\hline & & $\begin{array}{l}\text { 211. Defender o uso de modais de transportes mais sustentáveis para deslocamento diário da comunidade escolar } \\
\text { como um todo. }\end{array}$ & \\
\hline & $\checkmark$ & $\begin{array}{l}\text { 212. Oferecer transporte escolar gratuito, ao menos numa pequena porcentagem, caso esteja dentro da viabilidade } \\
\text { da escola. }\end{array}$ & \\
\hline & 些 & $\begin{array}{l}\text { 213. Verificar alternativas possiveis de acordo com a realidade de cada comunidade para mobilidade entre moradia } \\
\text { e escola, considerando: transporte público, vans, caronas, compartilhamento de veículos, motocicletas ou scooters, } \\
\text { andar de bicicleta, caminhar. }\end{array}$ & \\
\hline & 24 & $\begin{array}{l}\text { 214. Programas de mobilidade sustentável devem prever a proximidade de transportes públicos, faixas de pedestres } \\
\text { e ciclofaixas que atendam critérios normativos de segurança, mas também reduzir o deslocamento diário de } \\
\text { funcionários, seja por opção de trabalho remoto, seja pelo encorajamento de morar perto da escola. }\end{array}$ & \\
\hline
\end{tabular}




\begin{tabular}{|c|c|c|c|}
\hline AÇÃ & & & $\ddot{\theta} \odot \ddot{\theta}$ \\
\hline & $\checkmark$ & $\begin{array}{l}\text { 215. A sustentabilidade depende da eficiência e da qualidade de conservação dos espaços de aprendizagem e da } \\
\text { infraestrutura escolar; garantir um ambiente saudável, ventilado e seguro, com foco na supervisão. }\end{array}$ & \\
\hline & $\checkmark$ & 216. Garantir um saneamento seguro e manusear a água potável de maneira higiênica. & \\
\hline & $\approx$ & 217. Incluir a manutenção de longo prazo como um componente fundamental do projeto de escolas. & \\
\hline & (a) & $\begin{array}{l}\text { 218. Dispor de manuais e diretrizes de design são fornecidos aos profissionais no início do processo de projeto ou } \\
\text { de prestação de serviço e estabelecem o cenário previamente. }\end{array}$ & \\
\hline & (a) & $\begin{array}{l}\text { 219. Dispor de manuais de treinamento para informar a comunidade escolar sobre os padrões sustentáveis } \\
\text { construídos na edificação e estratégias de economia de energia. }\end{array}$ & \\
\hline 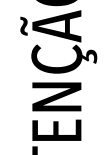 & 뜼 & $\begin{array}{l}\text { 220. } 0 \text { bom desempenho da construção e operações de um edificio escolar ao longo do tempo exige um gerenciamento } \\
\text { permanente de equipes de manutenção que cuidarão da conservação das estruturas e dos equipamentos durante } \\
\text { todo o seu ciclo de vida. }\end{array}$ & \\
\hline$\sum$ & $\approx$ & $\begin{array}{l}\text { 221. Estabelecer e seguir um programa preventivo e corretivo de comissionamento das operações e manutenções } \\
\text { prediais programadas. }\end{array}$ & \\
\hline & $\approx$ & 222. Diagnósticos de controle sobre os sistemas podem trazer inovação na manutenção dos edifícios escolares. & \\
\hline & $\checkmark$ & $\begin{array}{l}\text { 223. Durante obras de construções ou reformas, controlar as fontes de poluentes e interromper as vias de } \\
\text { contaminação. }\end{array}$ & \\
\hline & $\checkmark$ & 224. Eficiência de recursos e poluição mínima. & \\
\hline & $\approx$ & 225. Grades de drenagem nas portas ajudarão a impedir que água da chuva entre nas edificações. & \\
\hline & $\approx$ & $\begin{array}{l}\text { 226. O plano de prevenção da poluição em obras civis de construção ou reforma deve prever uma limpeza do edificio } \\
\text { ou teste os níveis de contaminantes do ar no edificio antes de sua ocupação pela comunidade escolar a fim de } \\
\text { proteger a saúde dos ocupantes dos edificios e o meio ambiente. }\end{array}$ & \\
\hline
\end{tabular}




\begin{tabular}{|c|c|c|}
\hline & $\approx$ & $\begin{array}{l}\text { 227. Sistema de gerenciamento de energia, aquecimento, captação de água de chuva, de iluminação e ar- } \\
\text { condicionado centralizados com interfaces simples para serem facilmente monitorados e poder ajustar o consumo } \\
\text { de recursos de acordo com o que é colhido. }\end{array}$ \\
\hline & $\checkmark$ & Impedir perda de água e consertar vazamentos em sistemas hidráulicos ou gotejamentos de água em torneiras. \\
\hline 巨 & 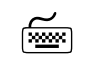 & 229. Realizar manutenção periódica de equipamentos para uso eficiente da energia. \\
\hline 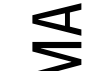 & $\approx$ & 230. Produtos e sistemas duráveis necessitam de menor manutenção e geram economia. \\
\hline & $\approx$ & $\begin{array}{l}\text { 231. Licitação com a incorporação de exigências de ações de sustentabilidade e responsabilidade social na } \\
\text { qualificação das empresas contratadas para serviços ou produtos. }\end{array}$ \\
\hline
\end{tabular}




\begin{tabular}{|c|c|c|}
\hline \multicolumn{2}{|l|}{ VALOR } & 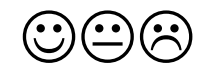 \\
\hline 24 & 232. É de interesse global promover e desenvolver escolas sustentáveis. & \\
\hline (1) & 233. Refletir criticamente sobre o conjunto de valores defendidos e atitudes praticadas. & \\
\hline 慗 & $\begin{array}{l}\text { 234. É fundamental que o currículo da escola em transição para a sustentabilidade estabeleça continuamente a } \\
\text { interação entre o que se aprende e o que se pratica, alinhando discurso e atitude, para que a escola seja congruente } \\
\text { com a sustentabilidade que ensina e forme cidadãos que apliquem os aprendizados recebidos à vida diária. }\end{array}$ & \\
\hline (1) & $\begin{array}{l}\text { 235. O funcionamento de um campus escolar reflete a filosofia da educação que impulsiona as políticas e práticas } \\
\text { educacionais. }\end{array}$ & \\
\hline & $\begin{array}{l}\text { 236. A sustentabilidade se constrói na concretude das ações, no compromisso com a ética, o humano e o planeta, } \\
\text { por meio de ações permanentes. }\end{array}$ & \\
\hline 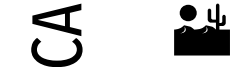 & 237. Ter consciência ética, respeito e sensibilidade sobre todas as formas de vida do planeta. & \\
\hline 풌 & $\begin{array}{l}\text { 238. Respeitar os pedestres com calçadas suficientemente amplas, desimpedidas, com rampas acessiveis, para } \\
\text { mobilidade e acessibilidade segura e confortável. }\end{array}$ & \\
\hline$\widetilde{\underline{\underline{\alpha}}}$ & $\begin{array}{l}\text { 239. Infraestrutura adaptada para a mobilidade e acessibilidade de alunos com diferentes tipos de deficiência } \\
\text { segundo as normas vigentes. }\end{array}$ & \\
\hline$\checkmark$ & $\begin{array}{l}\text { 240. Uso exclusivo de madeira legal adquirida em fornecedores cadastrados para construções novas, reformas ou } \\
\text { ampliações e na aquisição de mobiliário. }\end{array}$ & \\
\hline$\approx$ & $\begin{array}{l}\text { 241. Buscar a especificação correta de materiais e componentes em conformidade as normas técnicas ou } \\
\text { certificadas. }\end{array}$ & \\
\hline$\checkmark$ & Seguir as regras e normas para que os gerenciamentos de resíduos e transporte funcionem. & \\
\hline$\checkmark$ & Remunerar de forma justa e cuidar da saúde dos trabalhadores. & \\
\hline
\end{tabular}




\begin{tabular}{|c|c|}
\hline$\checkmark$ & 244. A ES se posiciona contrária a qualquer forma de suborno. \\
\hline (1) & $\begin{array}{l}\text { 245. Professores com conhecimento de EDS influenciem os alunos, e alunos com conhecimentos de EDS poderão } \\
\text { influenciar as atitudes e alterar comportamentos. }\end{array}$ \\
\hline (1) & $\begin{array}{l}\text { 246. } 0 \text { compromisso pessoal e os objetivos de ensino dos professores são fatores destacados como importantes para } \\
\text { a EDS. }\end{array}$ \\
\hline (1) & $\begin{array}{l}\text { 247. } 0 \text { processo de EDS começa com o conhecimento do conteúdo EDS, práticas de EDS, atitudes a partir da EDS e } \\
\text { termina com a construção de comportamento resultante da assimilação da EDS. }\end{array}$ \\
\hline 24 & $\begin{array}{l}\text { 248. Promover práticas sustentáveis que conservem os recursos naturais e limitem as emissões de gases de efeito } \\
\text { estufa. }\end{array}$ \\
\hline (1) & $\begin{array}{l}\text { 249. Edifícios escolares com elementos naturais interiores, motivos da natureza, luz do dia, entre outros diversos } \\
\text { componentes de mensagem visivel da sustentabilidade podem ser uma oportunidade para a mudança de } \\
\text { comportamento de seus ocupantes e melhorar o engajamento com relação por exemplo ao consumo de energia e } \\
\text { água. }\end{array}$ \\
\hline
\end{tabular}




\begin{tabular}{|c|c|c|}
\hline \multicolumn{2}{|c|}{ VALOR } & 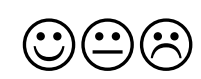 \\
\hline \multirow{10}{*}{ 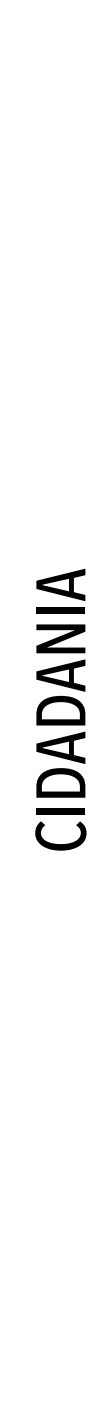 } & $\begin{array}{l}\text { 250. Defender a qualidade ambiental como um valor inseparável do exercício da cidadania em campanhas de } \\
\text { divulgação da sustentabilidade na instituição e com a participação em políticas públicas que abordem a } \\
\text { sustentabilidade. }\end{array}$ & \\
\hline & $\begin{array}{l}\text { 251. Transmitir a capacidade de transformar o conhecimento fundamental em ação consciente e irradiar soluções } \\
\text { sustentáveis para a comunidade e além. }\end{array}$ & \\
\hline & $\begin{array}{l}\text { 252. Promover uma consciência crítica e a interpenetração entre escola, comunidade e o meio ambiente com a } \\
\text { abertura da escola para a vida do bairro, os seus problemas e a sua comunidade mais ampla. }\end{array}$ & \\
\hline & Promover a conectividade da comunidade a diversos serviços básicos ao redor ou proximidades da escola. & \\
\hline & $\begin{array}{l}\text { 254. Diretrizes de sustentabilidade têm influenciado o cuidado dos alunos pelos outros, pelo meio ambiente e por } \\
\text { toda a comunidade. }\end{array}$ & \\
\hline & $\begin{array}{l}\text { 255. Demonstrar que uma mudança na educação regular para processos ascendentes que envolvem discurso, } \\
\text { reflexão crítica e ação são meios viáveis de abordar os desafios de sustentabilidade no nível da comunidade e de } \\
\text { incentivar abordagens de aprendizagem social, colaborativa e multidisciplinar. }\end{array}$ & \\
\hline & 256. Participar interessados na formulação e execução de pesquisas relacionadas à problemáticas ambientais. & \\
\hline & $\begin{array}{l}\text { 257. Comemorar datas e realizar campanhas de conscientização incentivando a divulgação de ações pela } \\
\text { sustentabilidade. }\end{array}$ & \\
\hline & $\begin{array}{l}\text { 258. Compartilhar sobre ações por diferentes meios de comunicação, como escrever blogss e posts em redes sociais, } \\
\text { criar vídeos, organizar comícios e demonstrações, exposições, peças de rua e flash mobs ou escrever para as } \\
\text { autoridades. }\end{array}$ & \\
\hline & $\begin{array}{l}\text { 259. Estimular o comportamento dos alunos em relação ao meio ambiente, preparando-os para serem indivíduos } \\
\text { responsáveis, éticos, com pensamento crítico e cidadania ativa em prol da sustentabilidade. }\end{array}$ & \\
\hline
\end{tabular}




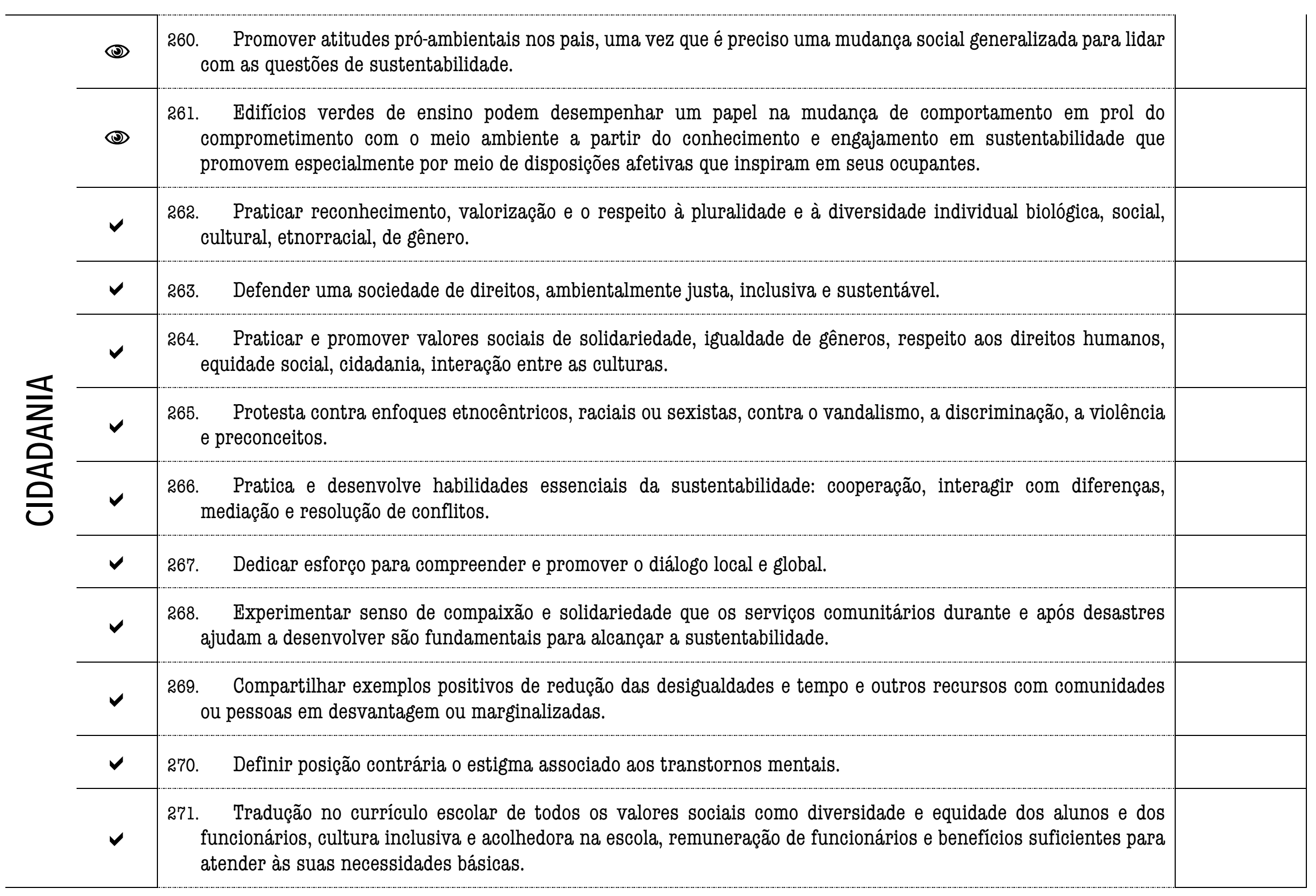




\begin{tabular}{|c|c|}
\hline$\checkmark$ & 272. Adquirir autonomia na busca do saber: autocapacitação. \\
\hline 昷 & $\begin{array}{l}\text { 273. Praticar o engajamento individual e coletivo na transformação local e global por meio de articulações de ações } \\
\text { de educação ambiental nas escolas e compartilhamento de responsabilidades pela mobilização das comunidades } \\
\text { como cidadão global ativo. }\end{array}$ \\
\hline & 274. Investigar e relatar exemplos que ajudam a erradicar a pobreza em vários níveis, de local a internacional. \\
\hline & 275. Dar suporte a esforços globais para atender aos ODS. \\
\hline$\sum$ & $\begin{array}{l}\text { 276. Formar uma cidadania ativa em favor da sustentabilidade por meio de ações como a de plantio de árvores que } \\
\text { contribuem para a economia, segurança alimentar e proteção das funçoses da paisagem ou a de crianças } \\
\text { participando de limpezas de rios ou praias, ou da estabilização da erosão do solo. }\end{array}$ \\
\hline$\stackrel{1}{=}$ & $\begin{array}{l}\text { 277. Favorecer parcerias com cooperativas e associações de catadores de lixo no município para a manipulação e } \\
\text { compra local dos resíduos gerados pela escola. }\end{array}$ \\
\hline$\approx$ & 278. Colaborar com autoridades, empresas e outras partes interessadas na sustentabiliadde. \\
\hline$\approx$ & Colaborar com alunos de outras escolas locais, de outras regiões ou com alunos em outros países. \\
\hline$\approx$ & 280. Facilitar e apoiar a resiliência da economia solidária local e justa. \\
\hline 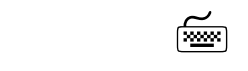 & 281. Apoiar o uso de materiais e produtos de preferência que possam ser adquiridos no comércio local. \\
\hline 24 & Reduzir ou ser seletivo em relação aos alimentos importados e estimular o consumo de alimentos locais. \\
\hline
\end{tabular}




\section{EXEMPLOS PRÁTICOS DE APLICAÇÕES}

As imagens e fotografias a seguir entre as páginas 42 e 48 são de projetos e obras de autoria de Yara Santucci Barreto, arquiteta, para intervenções sustentáveis em escola particular em São Paulo (SP), no periodo entre 2012 e 2014
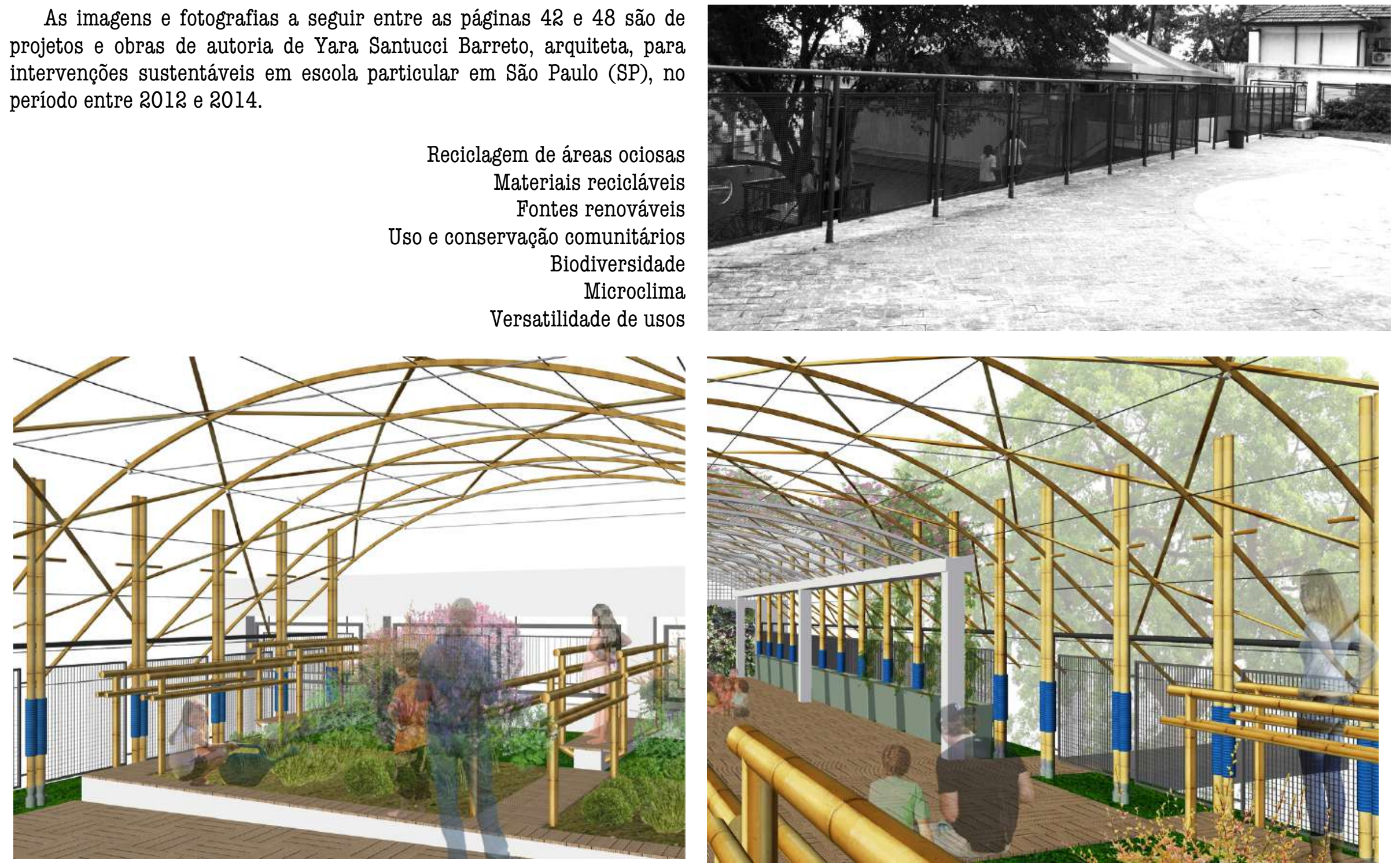

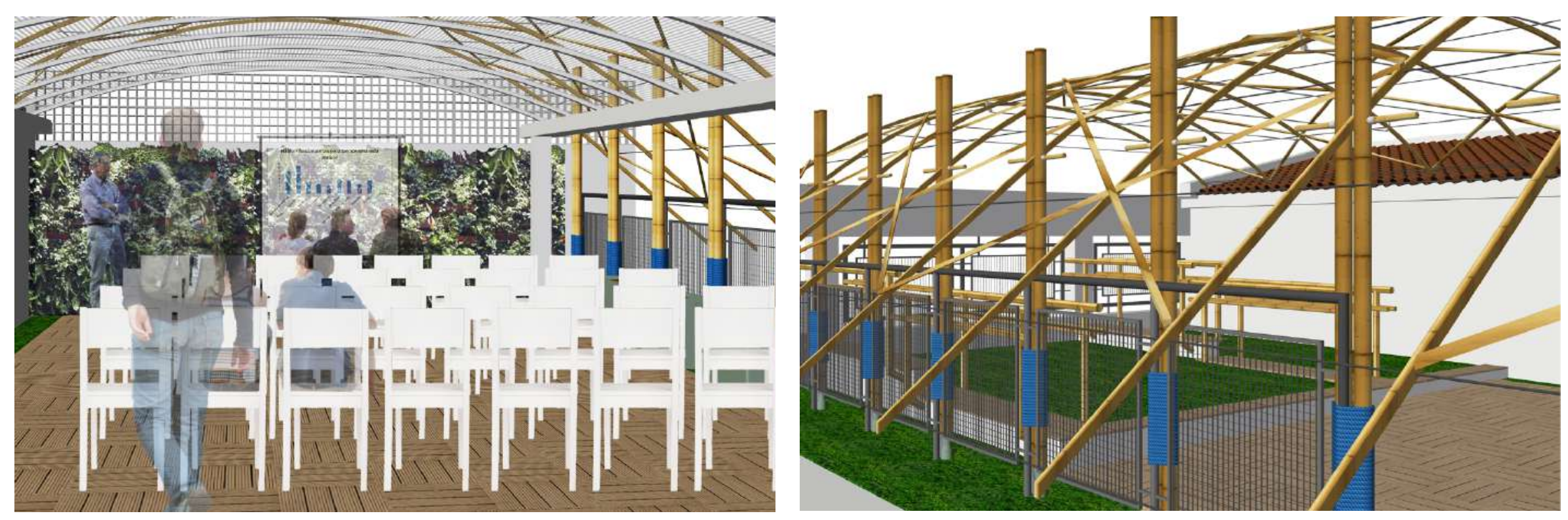

Fonte: Arquivo pessoal da Arq. Yara Santucci Barreto. 
Permeabilidade de pisos

Diminuição do descarte das águas pluviais na rede pública Redução de manutenções

Fonte: Arquivo pessoal da Arq. Yara Santucci Barreto.
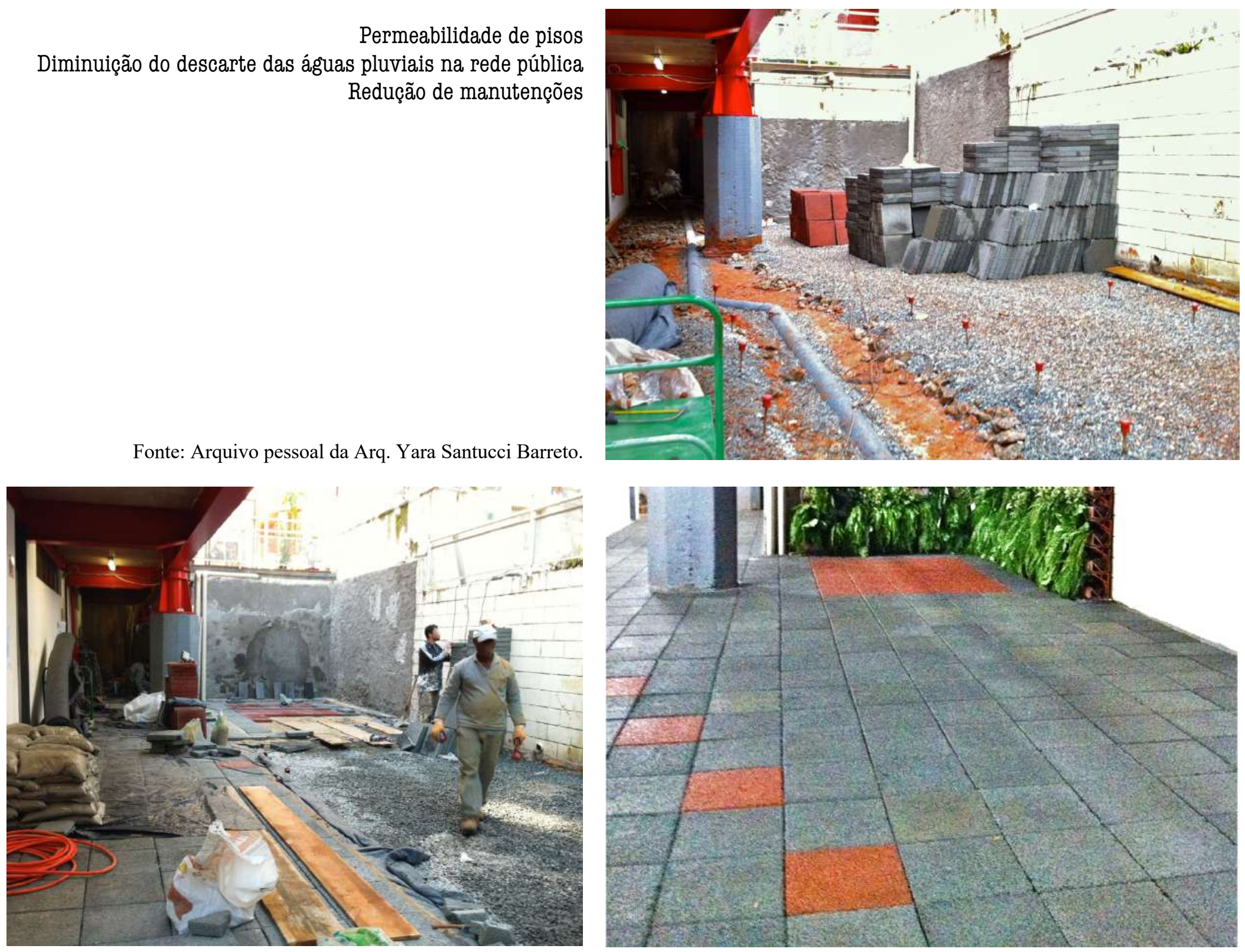
Estabilização da rede Redução de perdas energéticas

Proteção e segurança Distribuição, padronização e categorização por cores
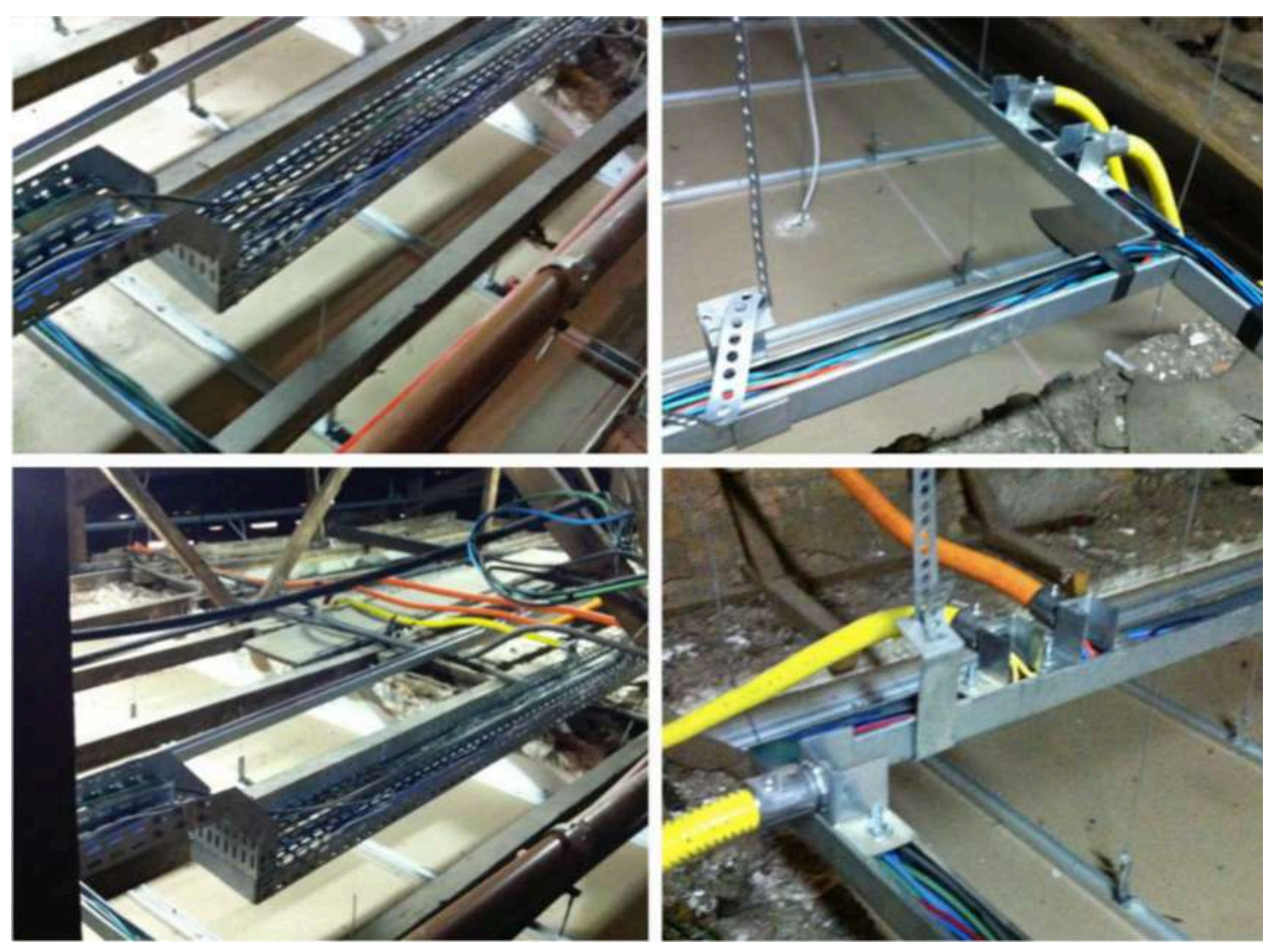

Fonte: Arquivo pessoal da Arq. Yara Santucci Barreto. 
Redução de manutencão de calhas e grelhas Captação e condução de águas pluviais

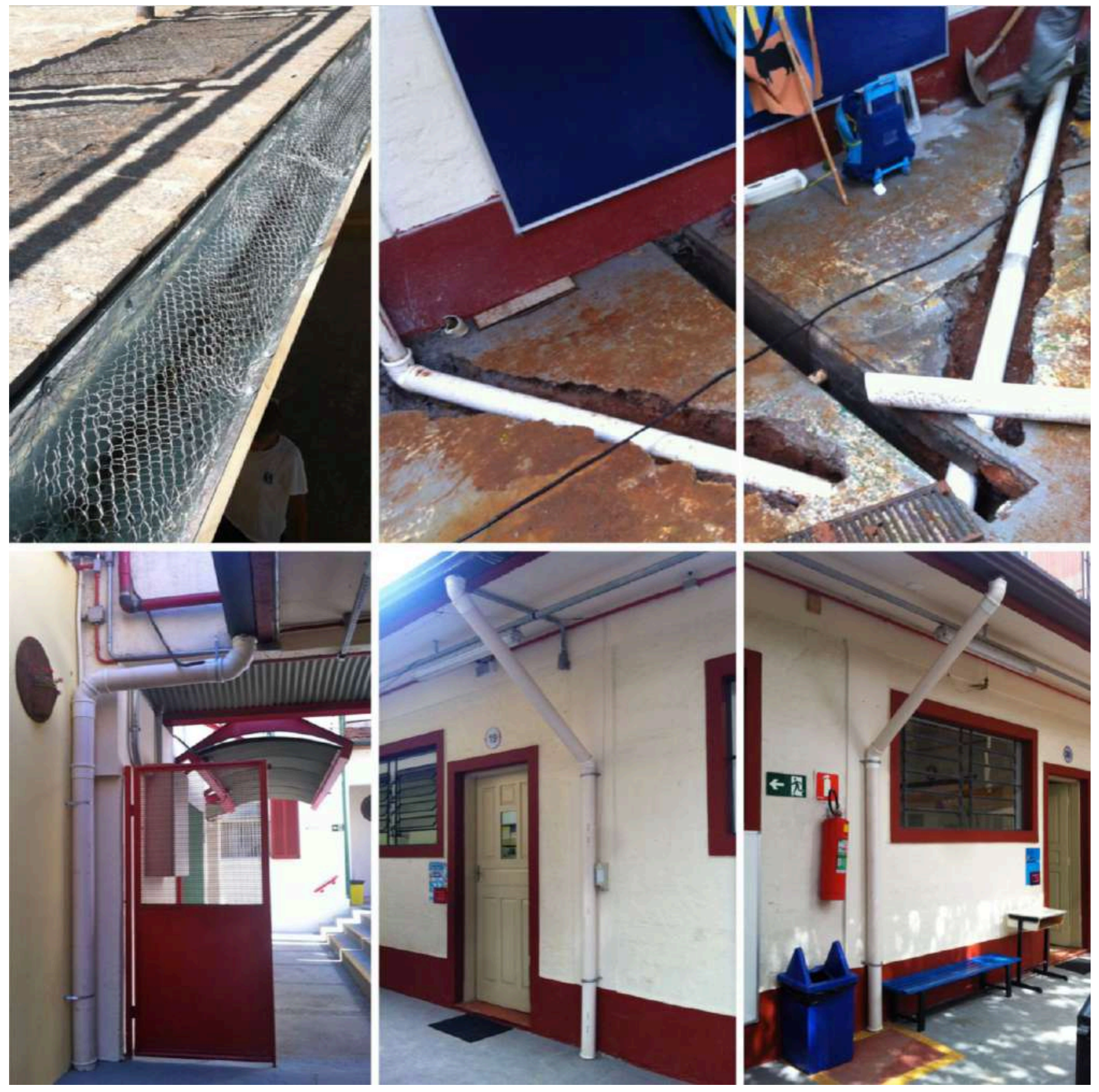




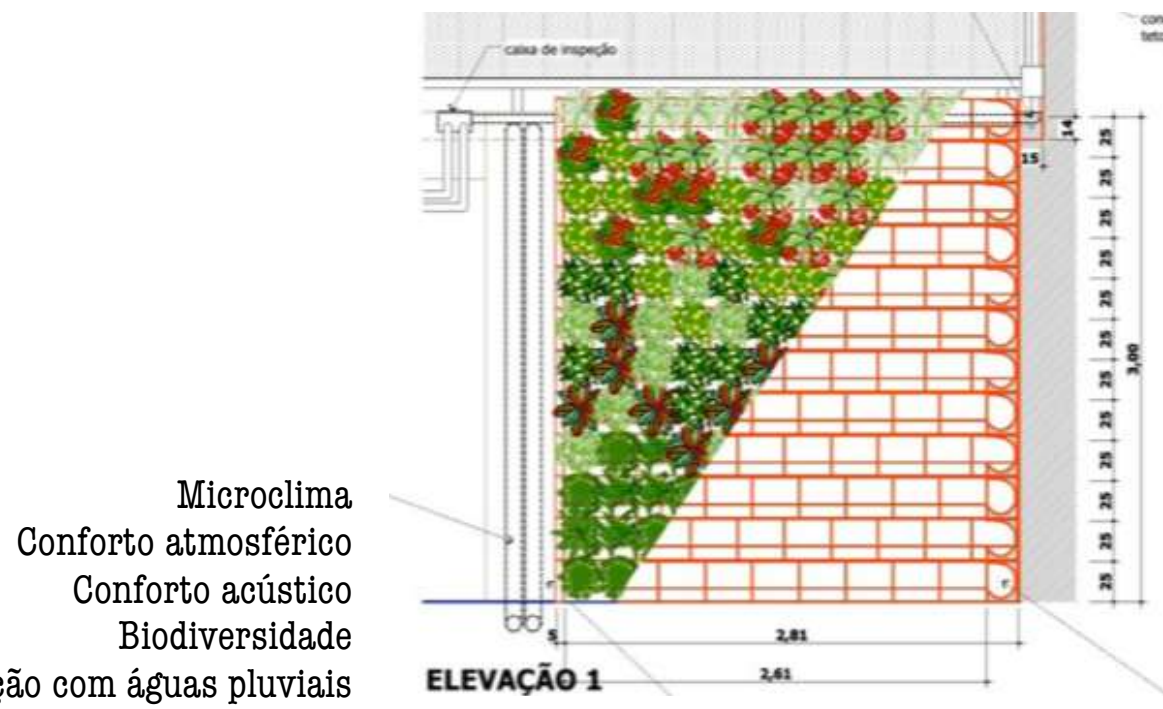

Fonte: Arquivo pessoal da Arq. Yara Santucci Barreto.
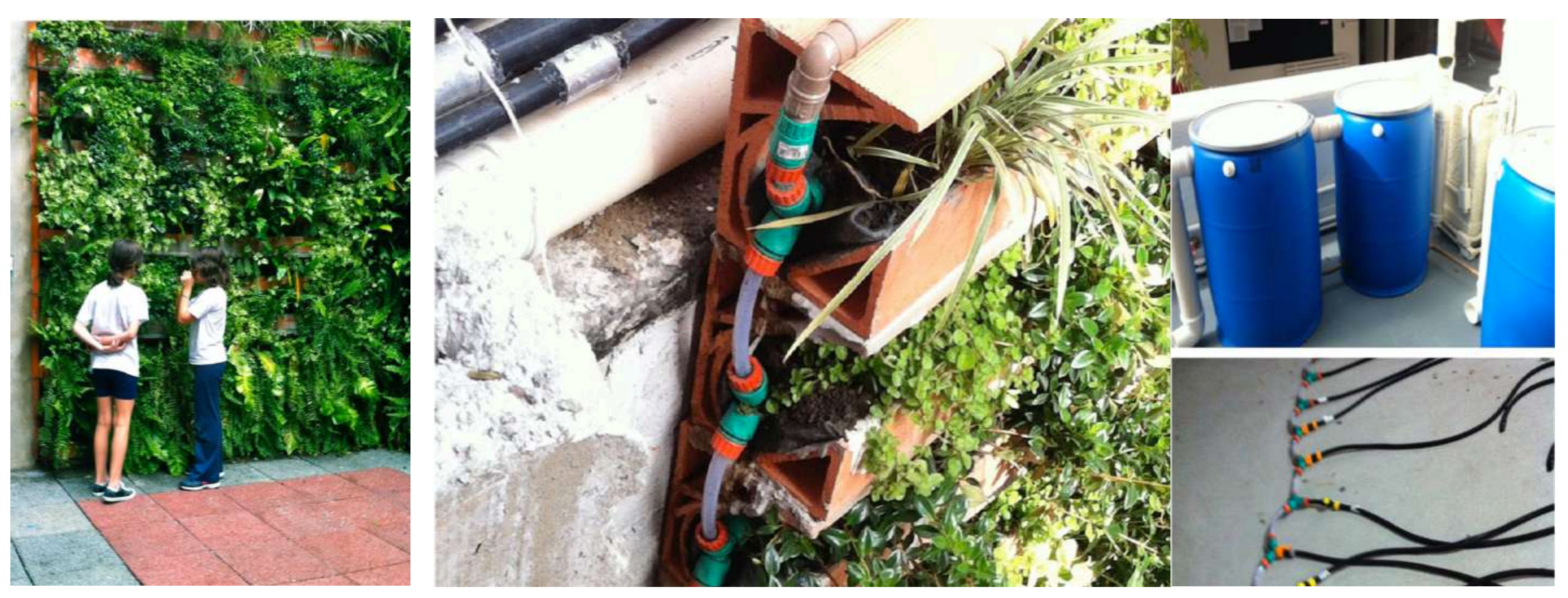
Mobiliário ergonômico Materiais recicláveis e de baixa manutenção
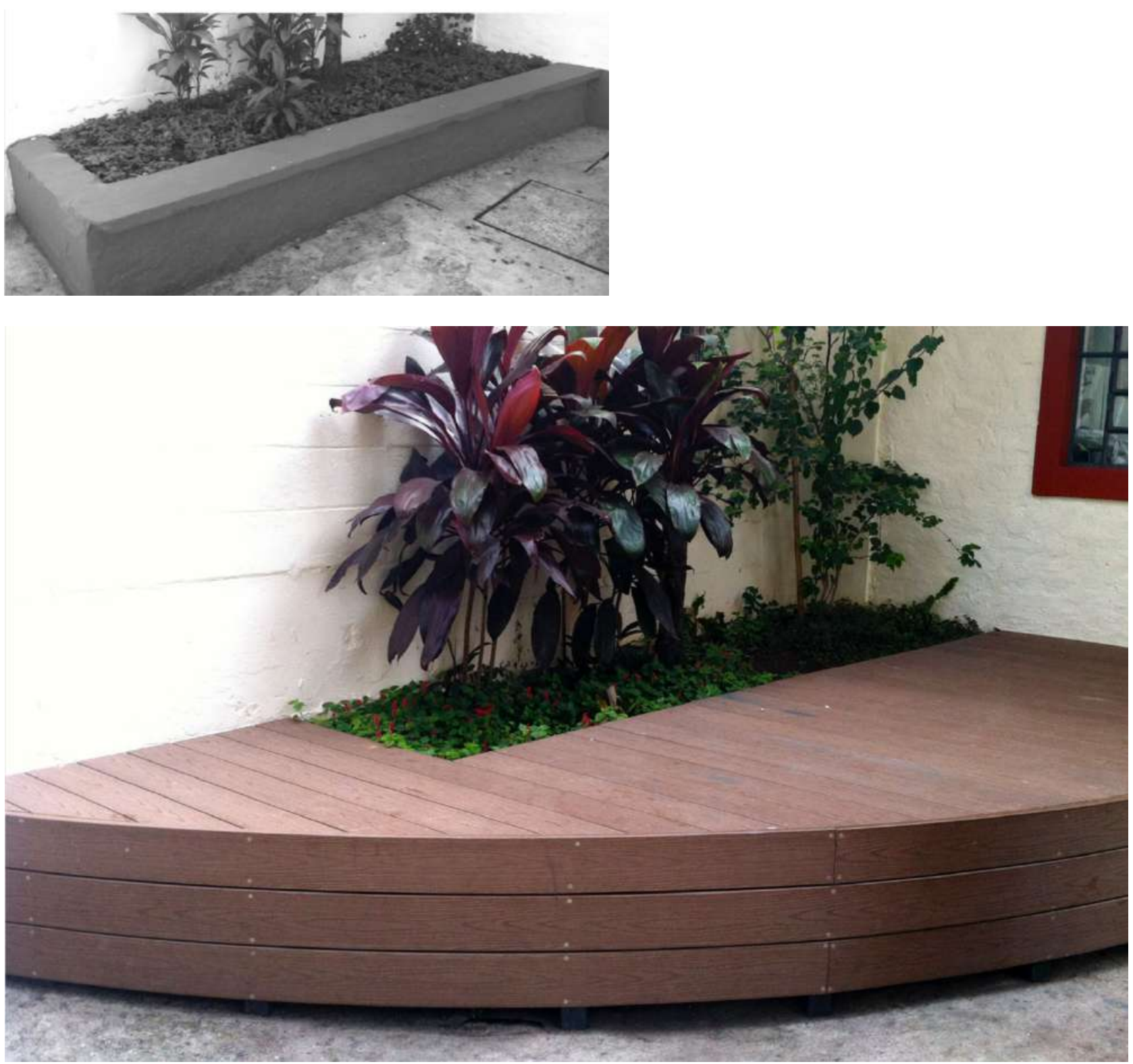


\section{REFERÊNCIAS}

ASSOCIATION FOR THE ADVANCEMENT OF SUSTAINABILITY IN HIGHER EDUCATION (AASHE). Stars ${ }^{\circledR}$ Technical Manual. Version 2.L. AASHE: Philadelphia, jun. 2019. 322 p.

BRASIL, Ministério da Educação e do Desporto - Coord. de Educação Ambiental. Implantação da Educação Ambiental no Brasil. Brasília, DF, 1998. 166p.

Lei no. 9.795, de 27 de abril de 1999. Dispõe sobre a educação ambiental, institui a Política Nacional de Educação Ambiental e dá outras providências. In: Educação Ambiental: aprendizes de sustentabilidade. Brasilia, DF, 2007. 95-99 p.

. Ministério da Educação. Secretaria de Educação Continuada, Alfabetização e Diversidade. Tratado de Educação para Sociedades Sustentáveis e Responsabilidade Global. In: Educação Ambiental: aprendizes de sustentabilidade. Brasília, DF, 2007. p. 103-107.

. Ministério da Educação, Secretaria de Educação Continuada, Alfabetização e Diversidade. Processo Formativo Escolas Sustentáveis e Com-Vida. Brasília, DF, 2010. 45 p.

Ministério da Educação. Conselho Nacional de Educação. Resolução $n^{\circ}$ 2, de 15 de Junho de 2012: estabelece as diretrizes curriculares nacionais para a educação ambiental. Brasília, DF, 2012.

. Ministério da Educação. Secretaria de Educação Continuada, Alfabetização, Diversidade e Inclusão. Vamos cuidar do Brasil com escolas sustentáveis: educando-nos para pensar e agir em tempos de mudanças socioambientais globais. Brasília, DF, 2012. 46 p.
Ministério da Educação; Secretaria de Educação Continuada, Alfabetização, Diversidade e Inclusão. Manual Escolas Sustentáveis Resolução CD/FNDE № 18, de 21 de maio de 2013. Brasília, DF, 2013.

LEI no 13.005, DE 25 DE JUNHO DE 2014: aprova o Plano Nacional de Educação - PNE e dá outras providências. Brasília, DF, 2014.

Ministério da Educação; Secretaria de Educação Continuada, Alfabetização, Diversidade e Inclusão; Diretoria de Políticas de Educação em Direitos Humanos e Cidadania; Coordenação-geral de Educação Ambiental. Programa Dinheiro Direto na Escola - PDDE Escolas Sustentáveis: guia de orientações operacionais. Brasília, DF, 2014.

Ministério das Relações Exteriores. Negociações da Agenda de Desenvolvimento Pós- 2015: Elementos orientadores da posição brasileira. 2014. $30 \mathrm{p}$.

Ministério do Meio Ambiente; Ministério da Educação. Recomendação Conama no11, de 04 de maio de 2011. In: Educação Ambiental por um Brasil sustentável - ProNEA: marcos legais e normativos - Brasília, DF, MMA 2018. p. 68-70.

Ministério do Meio Ambiente; Ministério da Educação. Educação Ambiental por um Brasil sustentável - ProNEA: marcos legais $\theta$ normativos - Brasília, DF, MMA 2018.104 p.

COLE, Laura B.; HAMILTON, Erin M. Can a green school building teach? A pre-and post-occupancy evaluation of a teaching green school building. Environment and Behavior, 2020, v. 52, n. 10, p. 1047-1078. 
FRANQUESA-SOLER, Montserrat; SANDOVAL-RIVERA, Juan Carlos A. Mentoring Program to achieve SDGs in local contexts: a case study in communities from southern Mexico. Sustainability: The Journal of Record, v. 12, n. 2, p. 109-114, 2019.

FUNDAÇÃO PARA O DESENVOLVIMENTO DA EDUCAÇÃO (FDE), Portal eletrônico. Apresenta serviços sustentáveis para escolas. 2019.

GORDON, Douglas E. Green Schools as High-Performance Learning Facilities. National Clearinghouse for Educational Facilities, 2010.

GOUGH, Noel \& GOUGH, Annette. The Green Schools Movement Around the World. In: PRESENTATION TO ASIAN STUDIES FACULTY AND STUDENTS, UNIVERSITY OF WESTERN AUSTRALIA, 2019.

HARB, S.; ELHAGGAR, S. M.; SEWILAM, H. Developing sustainable school guidelines: the case of Egypt. In: E3S Web of Conferences. EDP Sciences, 2019.

JORGE Graça, F..; COSTA, Marta M. da. High Performance School Buildings in Portugal: A Life Cycle Perspective. CELE Exchange, Centre for Effective Learning Environments, 2011/09. Paris: OECD Publishing, 2011.

KUUSKORPI, M.; GONZALEZ, N. Cabellos. The Future of the Physical Learning Environment: School Facilities that Support the User. CELE Exchange, Centre for Effective Learning Environments, 2011/11. Paris, OECD Publishing, 2011.

LEGAN, Lúcia. A escola sustentável: eco-alfabetização pelo ambiente. São Paulo: Imprensa Oficial do Estado de São Paulo; Pirenópolis: Instituto de Permacultura e Ecovilas do Cerrado (IPEC), 2007. 172 p.
MAHAT, Hanifah et al. Model development on awareness of education for sustainable schools development in Malaysia. Indonesian Journal of Geography, v. 48, n. 1, p. 37-46, 2016.

MOORE, K. Schools of the Future Initiative in California. CELE Exchange, Centre for Effective Learning Environments, 2011/07. Paris: OECD Publishing, 2011.

MOORE, Mary et al. Extending communities of practice: a partnership model for sustainable schools. Environment, Development and Sustainability, v. 21, n. 4, p. 1745-1762, 2019.

OECD. OECD School User Survey: Improving Learning Spaces Together. 2018. $51 \mathrm{p}$.

SHARMA, P. K. et al. Positive actions for the sustainable development goals. Foundation for Environmental Education, 2018. 48 p.

TUCKER, Richard; IZADPANAHI, Parisa. Live green, think green: Sustainable school architecture and children's environmental attitudes and behaviors. Journal of Environmental Psychology, v. 51, p. 209-216, 2017.

UNESCO; IBAMA. Educação ambiental: as grandes diretrizes da Conferência de Tbilisi. Brasília: 1997. 154 p.

USGBC. LEED 2009 For Schools New Construction and Major Renovations. USGBC, 2016. $109 \mathrm{p}$. 